ORNL --6643

Encrgy Division

DE91 005630

\title{
AN ASSESSMENT OF USING OIL SHALE FOR POWER PRODUCTION IN THE HASHEMITE KINGDOM OF JORDAN
}

\author{
Lawrence J. Hill \\ Robert S. Holcomb \\ Carl H. Petrich \\ R. Dickinson Roop
}

Datc Published: November 1990

Prepared for

Office of Fnergy, Science and Technology Bureau

U.S. AGENCY FOR INTERNATIONAL DEVELOPMENT

under Interagency Agreement No. DOE 1637-1637-A1

Prepared by

OAK RIDGE NATIONAL LABORATORY

Oak Ridge, Tennessee 37831

Operated by

MARTIN MARIETTA ENERGY SYSTEMS, INC.

for the
U.S. DEPARTMENT OF ENERGY

under Contract No. DE-AC05-84OR2140 


\section{TABLE OF CONTENTS}

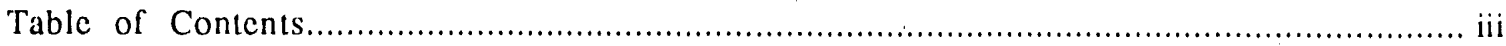

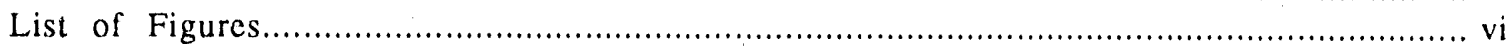

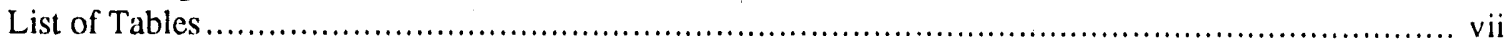

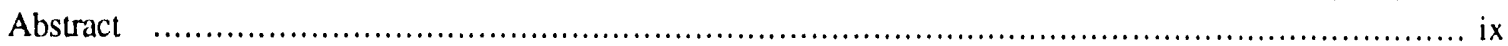

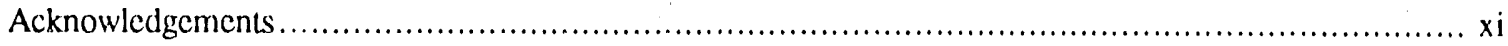

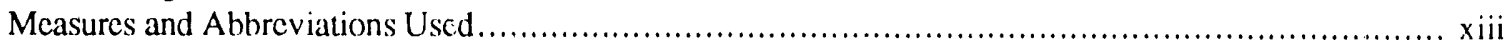

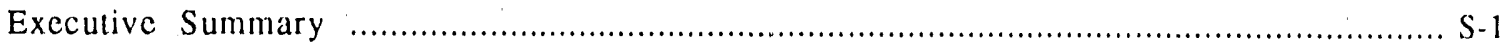

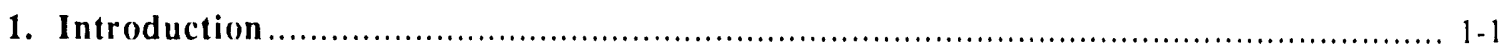

1.1 History of Project.................................................................................... $1-1$

1.2 Past Oil Shale Studies in Jordan..................................................................... $1-1$

1.2.1 Global Use of Oil Shale .......................................................... $1-1$

1.2.2 Jordanian Experience with Oil Shale ........................................... $1-2$

1.3 Location of Proposed Oil Shale Plant(s) ............................................... $1-2$

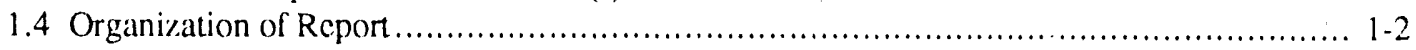

2. An Overview of the Jordanian Energy Sector................................................... 2-1

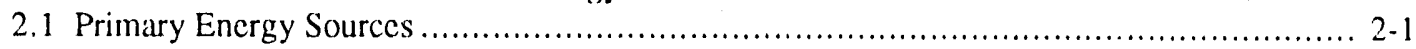

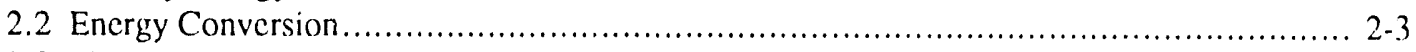

2.3 Final Encrgy Consumption................................................................ $2-5$

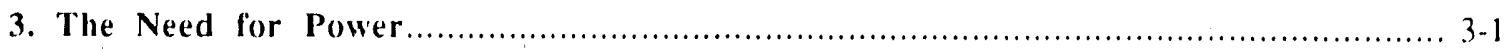

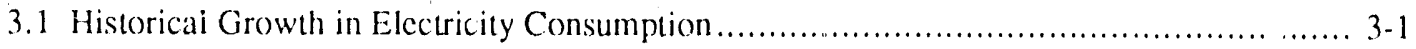

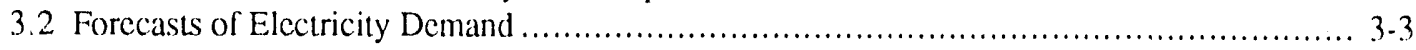

3.3 Complicating Factors in Assessing Future Electricity Demand.................................... 3-5

3.3.1 Power Interecennections and Exports................................................... 3-5

3.3.2 Demand-Side Management .................................................................. 3-6

3.3.3 Economic Growth.................................................................. 3-9

3.4 Assessment of the Need for Power ............................................................ 3-13

4. Accommodating Future Capacity Requirements.............................................. $4-1$

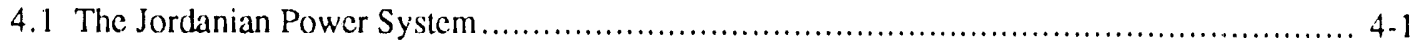

4.2 Current System Planning........................................................................ $4-5$

4.3 Potential Domestic Fuel Sources for Power Generation ........................................... 4-6

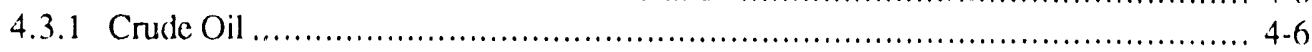

4.3.2 Natural Gas......................................................................... 4 -7

4.3.3 Renewable Energy.......................................................................... 4.8

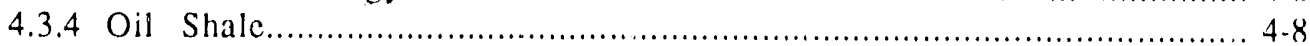

5. Circulating Fluidized Bed Combustion Technology ....................................... 5-1

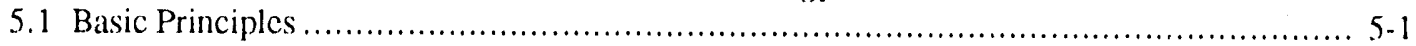

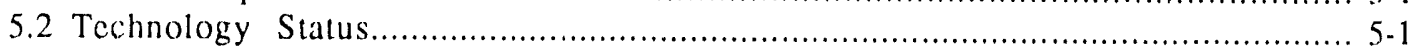

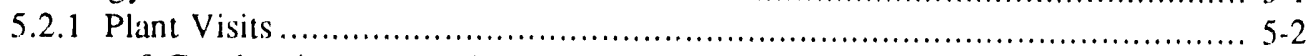

5.3 Summary of Combustion Tests of Jordan Oil Shale..................................................... $5-4$ 
6. Mine and Shale Oil-Fired Generating Plant Design............................................ 6-1

6.1 Mine and Materials Handling Systems................................................................. 6-1

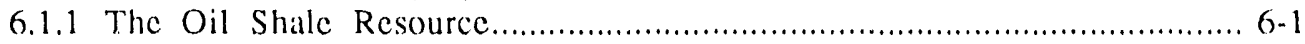

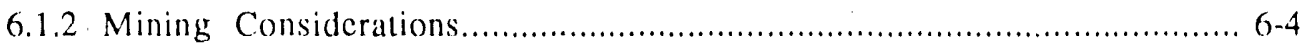

6.2 Shale Oil-Fired Generating Plant Design........................................................... 6-8

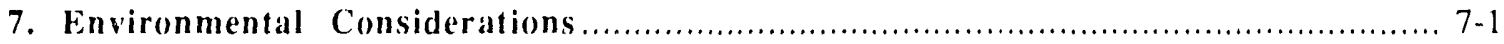

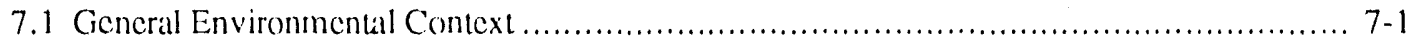

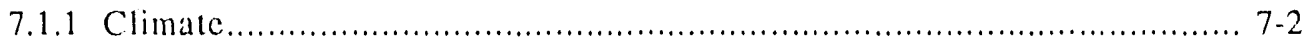

7.1 .2 Environmental Standards ............................................................ 7-2

7.1 .3 Wildlife and Wildlife Resoures ...................................................... 7-2

7.1.4 Archacology and Historic Sites.................................................. 7-4

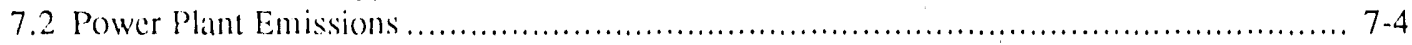

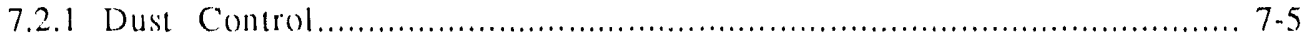

7.3 Overburden and Ash Disposal System .......................................................... 7-6

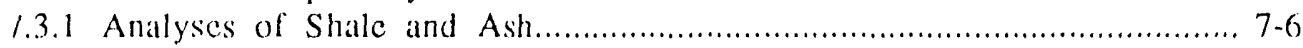

7.3 .2 Potential Water Quality Impacts ........................................................... 7-9

7.3.3 Potential Air Quality Impacts............................................................ 7-12

7.3.4 Potential Land Use Impracts................................................................. 7-13

7.3.5 Overburden Handling ....................................................................... 7-14

7.3.6 Resource Recovery........................................................................ 7-15

7.3.7 Vulnerability to Seismic Activity ................................................... 7-15

7.3.8 Noise Impacts ......................................................................... $7-15$

7.3.9 Secondary Environmental Impacts of the Proposed Project .......................... 7-16

7.3.10 Cumulative Impacts .................................................................. 7-16

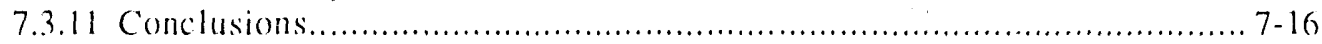

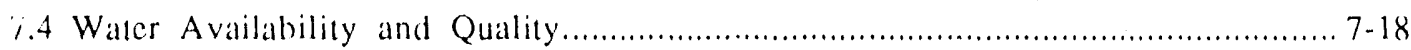

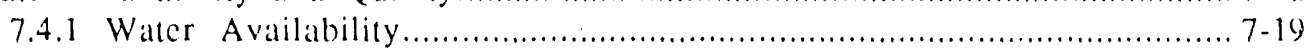

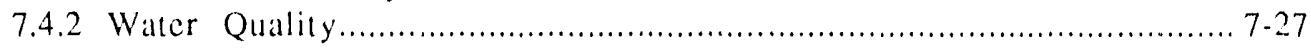

7.4.3 Ciroundwater Flow Regimes in the Wadi Mujib ................................... 7-28

7.4.4 Oil Shale Plant Water Requirements.................................................. 7-29

7.4.5 Potential Impacts of Oil Shale Plant on Groundwater

Quality and Quantity ............................................................ 7-32

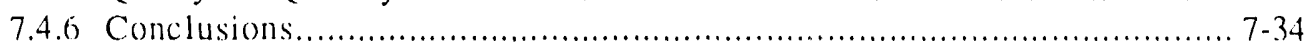

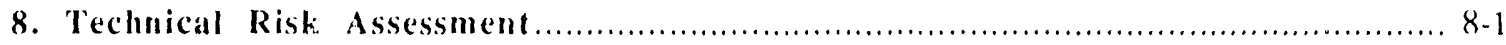

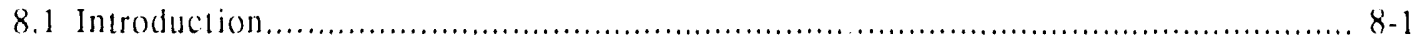

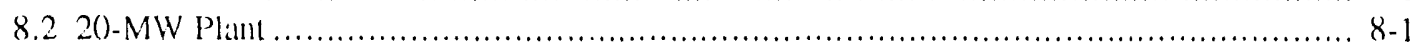

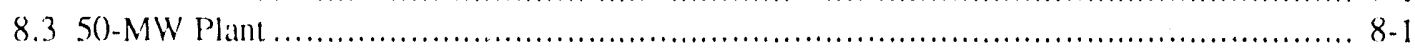

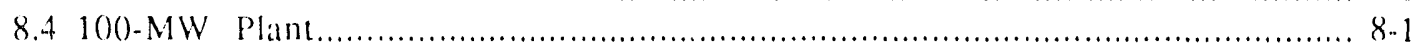

9. Financial/Economic Aspects of the Shale Alternative .................................... 9-1

9.1 Capital Expenditures.................................................................................. 9-3

9.2 Operation and Maintenance Expenses ............................................................... 9-6

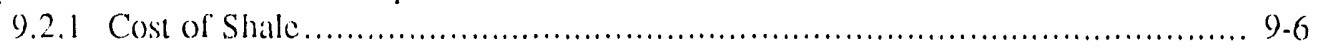

9.2.2 Residual Ash Disposal .................................................................. 9.7

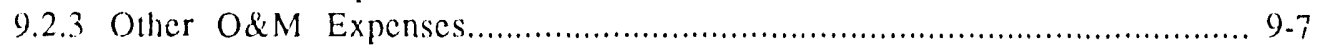

9.3 Financial Aspects of the Shale Alternative ....................................................... 9-8

9.4 Economic Analysis of the Shale Alternative...................................................... 9-9

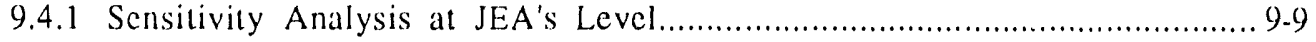

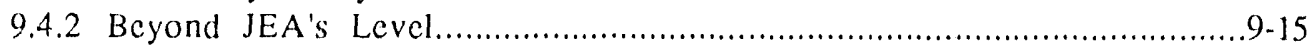




\section{Appendices}

Appendix A: Wildlif'e and Wildlife Resources ...................................................

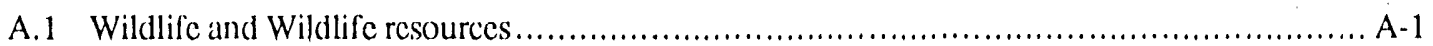

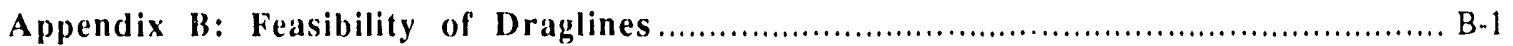

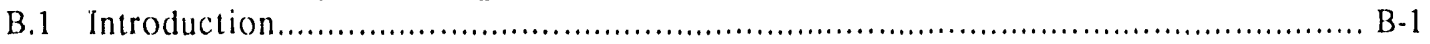

B.2 Findings on the Feasibility of Draglines ................................................... B-1

B.2.1 Multiple Small Draglines............................................................ B-1

B.2.2 Effect of Multiple Small Draglines on Annual Operating Costs....................... B-2

B.2.3 Effect of multiple Small Draglines on Operational Logisties and Safety .............. B-2

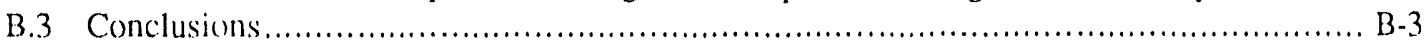

Appendix C: Health Efferts of Fly Ash and Other Dust..................................

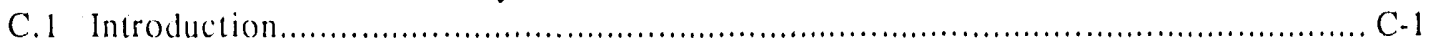




\section{LIST OF FIGURES}

Figure 1.1 Location of Sultani and El Laij.jun oil shale deposits ..................................... 1-4

Figure 2.1 Schematic Representation of the Jordanian Encrgy Sector ................................. 2-2

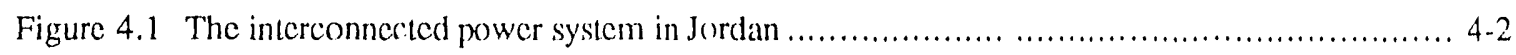

Figure 6.1 Preliminary Jordan oil shale project layout.................................................................. $6-2$

Figure 6.2 Oilshale flow diagram, 50-MW prototype Jordan oil shale processing plant.................... 6-7

Figure 6.3 Oil shale flow diagram, 4)()-MW full scale Jordan oil shale processing plant................... 6-9

Figure 6.4 Schematic conceptual facilities, Jordan oil shale-to-power project........................... $6-11$

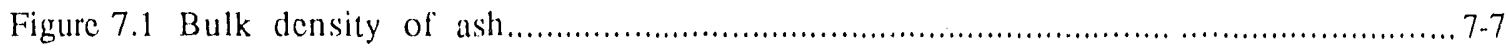

Figure 7.2 Particle size distribution of ash and crushed shale

from test burn of Jordanian oil shale....................................................... $7-8$

Figure 7.3 Particle size distribution of fly ash from test burn \#1 of Jordanian oil shale........................................................................ 7-9

Figure 7.4 Groundwater balance for the Wadi Mujib drainage.................................................. 7-30

Figure 7.5 Equipotential groundwater map of the EI Lajiun

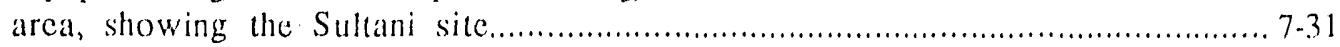

Figure 7.6 Net groundwater flow analysis of the El Laijun area, showing the Sultani sitc..................................................................... $7-32$

Figure 9.1 Schematic flow of major inputs and output, 50-MW plant ................................ 9-4

Figure A.1 Loxation of Jordan's 12 proposed wildlife reserves, showing the Abu Rukhah Wildlife Reserve just West of the Sultani site. 


\section{LIST OF TABLES}

Table S.1 Selected sensitivity results under current tariff structure, by capacily factor and capital expenditure scenarios, 4())-MW option

Table S.2 Selected sensitivity results under an assumed tariff increase, by capacity factor and capital expenditure scenarios, 50- and 400-MW option ................................. S-8

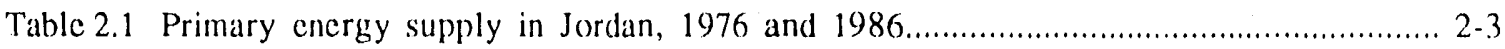

Table 2.2 Installed electric generating capacity in Jordan, by owner and prime mover, December 31, 1987

Table 2.3 End-use energy consumption in Jordan, 1976 and 1986.

Table 3.1 Jordanian electricity consumption, amount and percentage composition by sector, selected years, 1975-1987.

Table 3.2 Jordanian electricity consumption, average annual growth

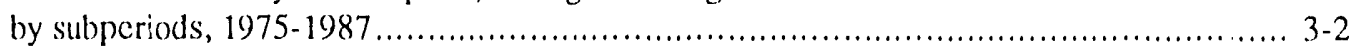

Table 3.3 Peak clectricity load in Jordan, selected years, 1975-1987 .......................................... 3-3

Table 3.4 Jordan Electricity Authority, summary of clectricity demand

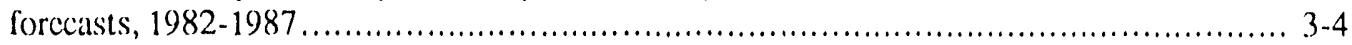

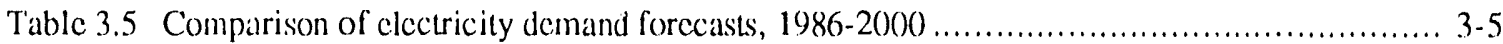

Table 3.6 Average annual growth in GDP and GNP, 1975-1987 ............................................ 3-9

Table 3.7 Analysis of gross national product, sclected ycars, 1976-1986

Table 3.8 Industrial electricity consumption, amount and percentage

composition by source, selected years, 1977-1987

Table 3.9 Output of major Jordanian clectricity users, selected years, 1977-1987

Table 3.10 Jordan power system, forecasted peak load, required capacity, and new capacity, thirty percent reserve margin, 1986-2005.

Table 4.1 Power gencrating stations, Jordan Electric Authority, by capacity and prime mover, December 31,1987 .

Table 4.2 Opcrating results for generating stations, Jordan Electricity Authority, eleven months $\sqrt{ }$ anuary-November, 1987

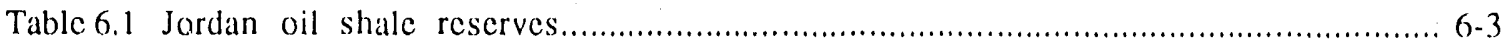

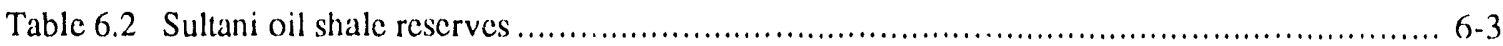

Table 6.3 Sultani oil shale reserves by oil content.......................................................................... 6

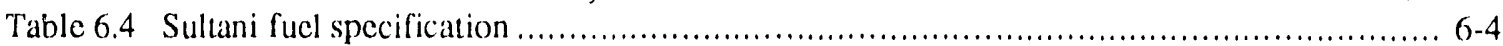

Table 6.5 Operating characteristics, three plant-size operations, Sultani oil shale project................... 6-10

Table 7.1 Climatic information for the Qatraneh area..................................................... 7-3

Table 7.2 Bulk density of shale and ash from eight test runs.................................................. $7-7$

Table 7.3 Results of Proximate, Ultimate, and Elemental Analyses.................................... 7-10

Table 7.4 Concentration of carbon and sulfur in raw shale

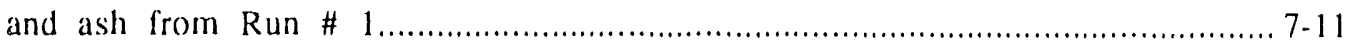

Table 7.5 Concentration of constituents in leachate from EP-Tox test on raw shale and ash from Run \#1 ................................................................ $7-11$

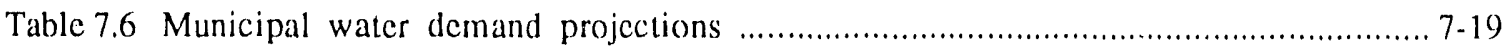




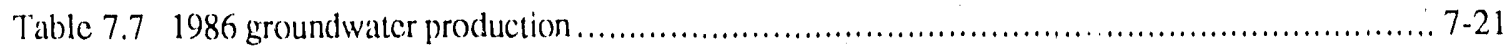

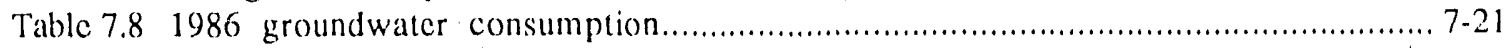

Table 7.9 Wadi Mujib Basin, current groundwater exploitation ........................................ 7-22

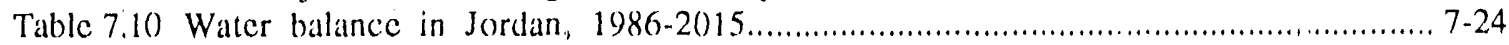

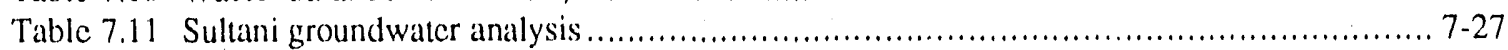

Table 7.12 Results of modeling Upper Wadi Mujib groundwater flows ....................................... 7-29

Table $7.13 \mathrm{Net}$ groundwater flow analysis of the El Lajjun area............................................. 7-33

Table 9.1 Capital expenditures, 2()-, 5()-, and 4(0)- MW options............................................. 9-6

Table 9.2 Mining and processing costs, 2()-, 50)-, 4())-MW options...................................... 9-7

Table 9.3 Residual ash disposal costs, 20), 50-, 40)-MW options ...................................... 9-8

Table 9.4 Other O\&M expenses, unit cost by plant size and capacity factor................................ 9.8

Table 9.5 Financial comparison of generating plant alternatives.............................................. 9-9

Table 9.6 Physical quantitics, alternative scenarios (by plant size and capacity factor)..................... 9-11

Table 9.7 Sensitivity results, alternative scenarios, base capital expenditures, 2()-, 5()-, and 4()()-MW plant options ............................... 9-12

Table 9.8 Sensitivity results, alternative scenarios, base $(0.75)$ capital expenditures, 2()-, 50)-, and 40)-MW plant options.................................... 9-13

Table 9.9 Sensitivity results, alternative scenarios, base(1.25) capital expenditures, 2()-, 50), and 40()-MW plant options.................................... 9-15

Table 9.1() Sensitivity results, altcrnative scenarios, base(1.5()) capital expenditures, 20)- 50)-, and 40)-MW plant options......................................... 9-16

Table 9.11 Sensitivity results, altcrnate scenarios, base(2.00) capital expenditures, 20, 50, and 400 MW plant options........................................ 9-17

Table 9.12 Summary of sensitivity results, 50-MW plant .......................................... 9-18

Table B.1 Annual operating costs compared: multiple draglines vs. truck

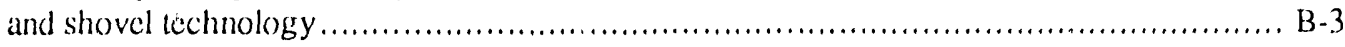

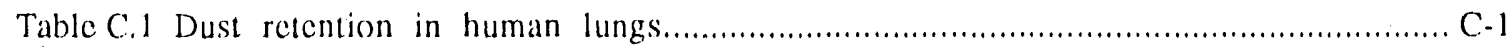




\title{
ABSTRACT \\ AN ASSESSMENT OF USING OIL SHALE FOR POWER PRODUCTION IN THE HASHEMITE KINGDOM OF JORDAN
}

\author{
Lawrence J. Hill \\ Carl H. Petrich \\ Robert S. Holcomb \\ R. Dickinson Roop
}

Up until the present, Jordan has relied almost exclusively on imported petroleum for its primary encrgy requirements. Encouraged by emerging technologies and recent fossil fuel discoveries, Jordanians are seriously examining exploitation of their own indigenous energy resoures to meet projected mid-and long-term power requirements. These resources include (1) potentially significant amounts of natural gas and some crude oil (both only recently discovered and not yet adequately quantified); (2) large oil shale deposits in at least four sites; and, to a lesser extent, (3) rencwable energy forms, including wind, sun, and biomass. Planning for future capacity expansion in the power sector is particularly difficult in Jordan because of uncertainties about the extent of its oil and gas reserves, the costs of exploiting its large oil shale reserves, and the future price of petroleum.

This report addresses the oil shalc-for-power-production option in Jordan. Under consideration are 2()- and 50)MW demonstration units and a 4(1)-MW, commercial-scale plant with, at the 4(0)-MW scale, a mining opcration capable of supplying 7.8 million tonnes per year of shale fuel and also capable of disposal of up to 6.1 million tonnes per year of wetted ash. The plant would be a direct combustion facility, burning crushed oil shale through use of circulating fluidized bed combustion technology. The report cmphasizes four areas: (1) the need for power in Jordan, (2) environmental aspects of the proposed oil shale-for-power plant(s), (3) the enginecring feasibility of using Jordan's oil shale in a circulating fluidized bed combustion (CFBC) boiler, and (4) the cconomic feasibility of the proposed plant(s).

Assessing Jordan's future power needs is complicated by the possibility of power imports from and exports to neighboring Arab countries, by demand-side management activitics, and by uncertainty about growth prospects for the Jordanian economy. Thus, there is no "best" projection of future power demand in Jordan. Laboratory analyses of ash residues from a recent test burn of the Jordanian shale suggests that there would be no severe environmental affects from leachates. Sulfur emissions would be largely neutralized by the carbonate in the shale. $\mathrm{NO}_{\mathrm{x}}$ emissions would likely be within ranges typical for comparably-sized coal-fired power plants in the U.S. and would be well within World Bank standards. The major health and environmental protection challenge would be the control of fugitive dust and tly ash, both would be at sizes readily respirable and retained in human lungs. The long-term toxicity of breathing such dust is unknown. Based on results of the test burn and recent improvements and experience with CFBC technology, it appears from a technical perspective that Jordanian shale could be successfully exploited.

A sensitivity study was conducted to determine the economic feasibility of the proposed plant(s) under different cost assumptions and revenue flows over the plant's lifetime. The results suggest that the 2()-MW plant is not an economically attractive option under any circumstances. Under the rate level in existence for 1987 and most of 1988 , the 50-MW option is not an attractive alternative either. Under this rate structure, the returns for the 40)-MW plant approach or exceed Jordan Electricity Authority's opportunity cost of capital under only the most favorable cost and operating assumptions. Increasing the tariff level results in more favorable conclusions for the 5()- and 4)()-MW options under various input assumptions. The sensitivity results are extended to include the major extra-firm benefits of the shale-for-power option: (1) foreign exchange savings from using domestic energy resources, (2) aggregate income effects of using Jordan's indigenous labor force, and (3) a highei level of energy security. 


\section{ACKNOWLEDGEMENTS}

The authors wish to acknowledge :everal individuals for their work and support in the preparation of this report. We thank our sponsors at the U.S. Agency for International Development's Office of Energy in the Bureau for Science and Technology for their gencial project support and their most helpful review comments through the early development of the final report. In particular, we thank James Sullivan, Director of the Office, and Robert G.imshaw, the project manager. Donald Hunsaker and Ron Kraemer of ORNL's Energy Division provided constructive review comments on the environmental analysis for which we are most grateful. David Bjornstad and Glenn Stevenson also of the Energy Division provided thoughtful review comments on the economic and financial analyses and the assessment of the need for power. We are grateful to the Operations Division for assisting in the storage of the fly ash shipped from Finland and for assisting in the chemical analyses of the aish and raw shale. We appreciate the extra efforts in project coordination made by our collaborators from Bicchtel National, Inc. (Bill Linton, Doug Gould, and Dick Buta) and from Pyropower Corporation (Kix Aulisio). 


\section{MEASURES AND ABBREVIATIONS USED}

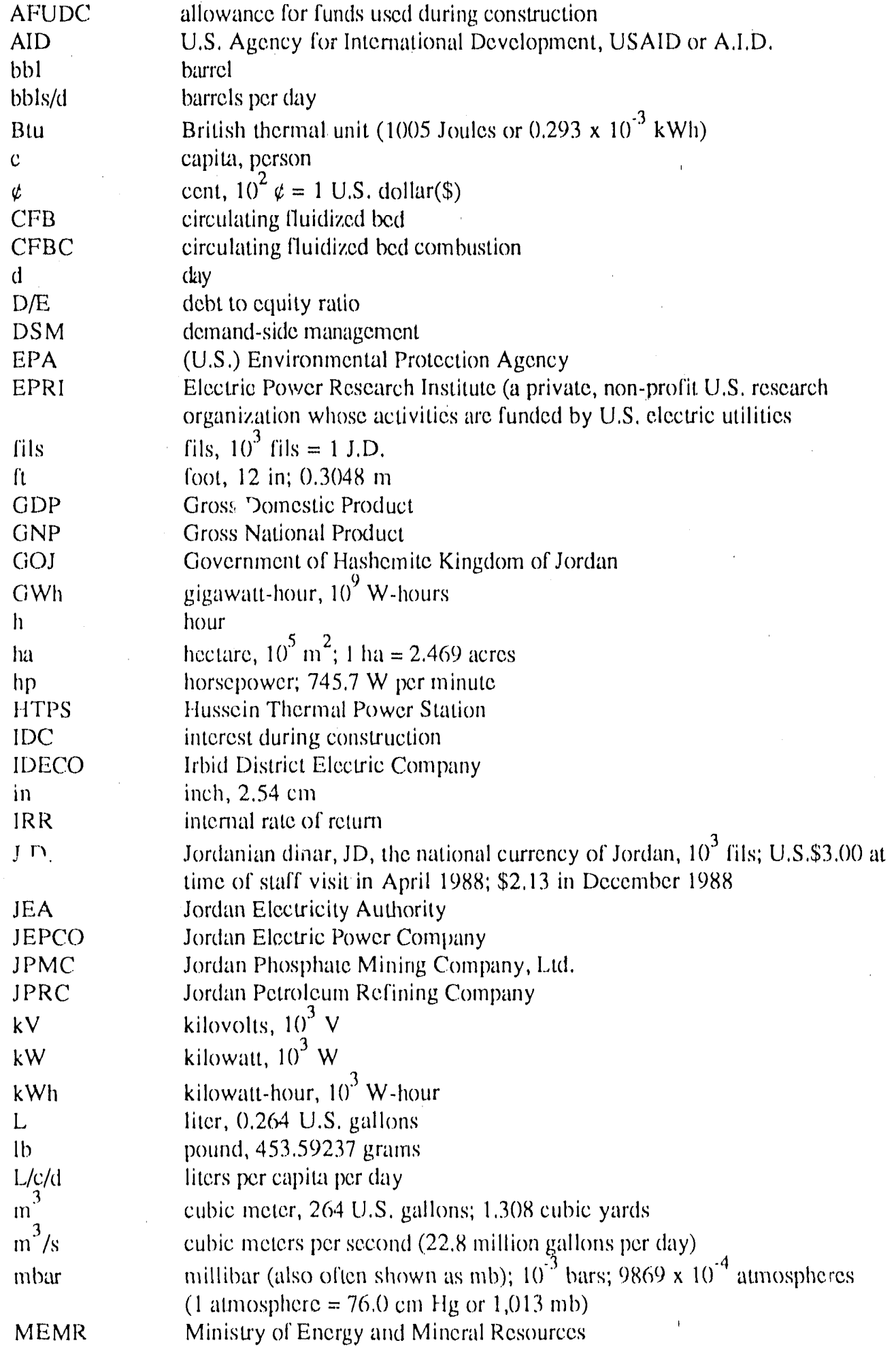




\begin{tabular}{|c|c|}
\hline $\begin{array}{l}\text { MOP } \\
\mathrm{Mm}^{3}\end{array}$ & $\begin{array}{l}\text { Ministry of Planning } \\
\text { million cubic meters }\end{array}$ \\
\hline MMSCFD & $\begin{array}{l}\text { million cubic meters } \\
\text { million standard cubic feet (of natural gas) per day }\end{array}$ \\
\hline M\&I & municipal and industrial \\
\hline MBtu & thousand British thermal units $\left(10^{3} \mathrm{Btu}\right)$ \\
\hline MW & $\begin{array}{l}\text { megawatt (clectric), MWe, } 10^{3} \mathrm{~kW}, 10^{6} \mathrm{~W} \text {, all measurements in this report } \\
\text { expressed as } \mathrm{MW} \text { are considered MWe unless designated MWt (MW thermal) }\end{array}$ \\
\hline$\mu$ & micron, $10^{-6} \mathrm{~m} ;$ micro- $10^{-6}$ \\
\hline NPV & net present value \\
\hline $\mathrm{NO}_{x}$ & nitrogen oxides \\
\hline NRA & Natural Resources Authority of the GOJ \\
\hline ORNL & Oak Ridge National Laboratory; Oak Ridge, Tennessec, USA \\
\hline$\nabla \mathrm{p}$ & CFB bed pressure \\
\hline PV & photovoltaics \\
\hline $\mathrm{ppm}$ & parts per million \\
\hline psia & pounds/in 2 /atmospheric pressure \\
\hline RCRA & (U.S.) Resource Conservation and Recovery Act \\
\hline$\$$ & U.S. dollar, national currency of the United States of America, $10^{2} \phi$ \\
\hline $\mathrm{s}$ & second \\
\hline $\mathrm{SO}_{2}$ & sulfur dioxide \\
\hline 1 & 1 metric tonne, $10^{3} \mathrm{~kg}, 22(04.6$ pounds \\
\hline ton & $200(0)$ pounds, 0.907 tonnes \\
\hline TW & tcrawalt, $10^{12} \mathrm{~W}$ \\
\hline tpy & tonnes per year, $t / y$ \\
\hline TOE & tonnes of oil equivalent; $44.76 \times 10^{9}$ Joules, \\
\hline U.S. & United States of America \\
\hline w & Watl \\
\hline WAJ & Water Aulhority of Jordan \\
\hline$y$ & ycar \\
\hline
\end{tabular}




\title{
EXECUTIVE SUMMARY
}

\section{AN ASSESSMENT OF USING OIL SHALE FOR POWER PRODUCTION IN THE HASHEMITE KINGDOM OF JORDAN}

\author{
Lawrence J. Hill \\ Carl H. Petrich \\ Robert S. Holcomb \\ R. Dickinson Roop
}

In Spring 1986, the Bechtel Group, Inc. of San Francisco, CA, completed a cursory examination of building a 20-MW demonstration oil shale-for-power production plant in western Jordan. Based on this study, the U.S. Agency for International Development (AID) agreed to fund through the Government of Jordan (GOJ) a more rigorous study of the potential for using oil shale for power production. In this report, we address a mine-power plant complex utilizing circulating fluidized bed combustion technology. Specifically, the feasibility of 20- and 50-MW demonstration units and a 400-MW commercial-scale plant are considered. The study addresses four areas: (1) the need for power in Jordan over the next two decades; (2) environmental aspects of the proposed plant(s); (3) the enginecring feasibility of using Jordanian oil shale in a circulating fluidized bed (CFB) combustor; and (4) the economic feasibility of the proposed plant(s) and mining operations. The studv was led by the Bechtel Group, Inc., under the AID Conventional Energy Technical Assistance Project, with input provided by the Pyropower Corporation of San Diego, CA (pilot test work and the boiler designs and costs estimates) and Oak Ridge National Laboratory (ORNL). The Bechtel Group also provided conceptual designs for the balance-of-plant facilities beyond the boiler and developed the estimated capital and operating costs for all of the integrated project facilites, including the mine and raw shale processing facilities. ORNL also independently evaluated for AID the reasonableness and accuracy of the Bechtel and Pyropower conclusions.

Energy planning in Jordan is complicated by uncertainties surrounding the extent of indigenous petroleum and natural gas resources and, given these unecrtainties, the optimal use of its sizcable oil shalc resources. Jordan is currently producing approximatcly 1,000 barrels per day (bbls/d) of crude petroleum; its total petrolcum nceds, however, exceed $60,000 \mathrm{bbls} / \mathrm{d}$. There is ongoing exploration by three international oil companies which took petroleum concessions in 1986. The prospects for discovering significani amounts of crude oil, however, are still uncertain at the present time. Similar to the uncertainty surrounding petroleum resources, there are insufficient geological data to speculate on the extent of natural gas reserves at the present time. The Government of Jordan has two gas wells presently in operation at Risha in the northeastern part of the country that have been tested at 20 MMSCFD (million standard cubic fect per day). Based on this optimistic finding, the government is committed to installing $2 \times 30$ - MW gas turbines at the Risha site (to be completed by late 1988 or carly 1989) and to constructing a $132-\mathrm{kV}$ transmission line over the $334 \mathrm{~km}$ from the capital at Amman to the Risha fields. The government muy ultimately add up to $4 \times$ 30-MW gals turbines at the Risha fields, reaching the capacity of the $132-\mathrm{kV}$ transmission line. ${ }^{1}$ Four oil shale sites have been cored, drilled, and studied to date, with resulting data published for three of these. The three sites comprise nearly one-half of the country's proven geological reserves of more than 10 lillion tons. Possibilities for exploiting the shale include indirectly using it (retorting) for producing a liquid fuel and directly using it as a high residual ash fuel in power production. Both options are currently being explored by the Jordanian government.

\footnotetext{
1 PetroCanada is currently conducting a reservoir study to ascertain the size of the reserves at the Risha site. The study was expected to be completed by carly 1989 , but as of this printing is not yet available.
} 


\section{Projected Power Needs in Jordan}

The power scetor in Jordan has grown rapidly over the past two decadss, especially in the late 1970s and early 1980s when an economic boom led to increased demand for electricity and a consequent increase in generating capacity. From 1975 to 1987, clectricity consumption increased at an average annual rate of 20.2 percent. Generating capacity in the country increased to $979 \mathrm{MW}$ by the end of 1987. More recently, however, grow in in electricity consumption has slowed. In the two-year period from 1985-1987, consumption grew at an average anriual rate of "only" ij.\& percent.

An important question for power planning in Jordan is the future growth of alectricity demand. Estimates of future capacity requirements to meet expeciud lo il growth until the year 2005 range from $543 \mathrm{MW}$ to more than $1,500 \mathrm{MW}$, assuming a $3 \mathrm{v}$ percent reserve margin. Three aspects of the Jordanian economy and power subsector make cvaluation of future electricity consumption especially difficult:

- There is a great deal of unceriainty about the net impact on electricity sales of the "otential interec nnections among the national power systems of Jordan, Syria, Egypt, and Saudi Arabia. Currently, Jordan exports power to Syria. However, in September 1988, the governmunts of Jordan and Egypt signed a technical protocol for constructing a transmission line linking the power systems of both countries, with implementation expected to commence in carly 1989. Also, Jordan and Egypt agreed to study the feasibility of connecting both their national grids to Saudi Arabia.

$4 \quad$ Uncertainty surrounds the impact of both implemented and implementable demand-side management programs on future clautricity demand.

- There is uncertainty about the future growth of the Jordanian economy. For one, the country's population is growing at an unusually high 3.8 percent annual rate, and not expected to decline io a still-high rate of 3.2 percent until around 2010 . Historically, remiltances by Jordanians employed in other Middle Eastern countries have accounted for a large share of gross income in the economy. With the recent decline in intemational petroleum prices, however, construction programs have becn cancelled or delayed, jeopardizing future income from an historically important source. Uncertainty also surrounds the future growth of the industrial sector; it currently accounts for 40 percent of electricity demand. Large industrial power users in five industries, producing largely for export markets, account for more than 75 percent of this total. Fuiure export markets for these industries are uncertain.

\section{Engineering Feasibility of the $\mathrm{CFB}$ Combustion Technology}

While fluidized bed boilers have been available for decades, they have started to make headway in commercial applications in recent years because of their high efficiency, clean burning characteristics, and ability to burn a variety of fucls. Rising oil prices over the past 15 years have contributed much to fluidized bed technologies' marketplace penetration. Throughout the world, there are 52 manuiacturers of three types of fluidized boilers: bubbling bed, circulating, and pressurized.

Circulating fluidized bed (CFB) is a second-generation technology wherein the boilers are designed to burn lowcost, high sulfur coal or other waste products, producing steam and electricity without the need for expensive treatment of the exhaust strcam. In a CFB boiler, high velocity air "fluidizes" a crushed fuel mix in the combustion chamber, transporting the solids up the chamber, where waterwalls are heated. Large, hot cyclones return the unfired fuel and other solids to the combustor chamber where they will, on the average, make several passes through the system before leaving as flue gases or as ash. Low operating tc. nperatures minimize $\mathrm{NO}_{\mathrm{x}}$ 
emissions, and the use of limestone (where needed) can reduce $\mathrm{SO}_{2}$ sufficiently to avoid having to use costly scrubbers.

First introduced begiming in 1979, there have been about 75 CFB boiler plants built worldwide. They have been designed to burn a wide variety of fuels: wood waste, peat, lignite, bituminous coal, coal washery tails, anthracite culm, indusurial wastes and sludges, petroleum coke, and others.

The technology has beci? successf tllly demonstrated in units as large as $60 \mathrm{MW}$, but not with high-ash fuels such as the Jordanian oil shale. There are no indications that there wou!d be any problems in successfully demonstrating larger plants except that managing the implications of the fucl's ash content will certainly be challenging.

Combustion tests of Jordan's oil shale were conducted in the Ahlström CFB test unit at their R\&D Center in Karhila, Finland from January 11-20, 1988. The test program consisted of a series of runs in which one or more of the key operating parameters was changed for cach run so that the effects on the combustion performance could be determined. Conclusions are:

The Jordanian oil shale, because of its high ash content, is a more challenging fucl than bituminous coal, for example, for use in s aaiing up to larger plants. The large quantities of ash which would be circulated through the combustor and returned by the hot cyclone would place a heavy demand on the return leg and loop seal.

$\square \quad$ The Sultani oil shale's high volatile content should make it easy to start and would burn gencrally well even down to low loads.

Low $\mathrm{SO}_{2}$ (10 to $200 \mathrm{ppm}$, or 95 percent sulfur removal) and only moderate $\mathrm{NO}_{\mathrm{x}}$ (60 to $120 \mathrm{ppm}$ ) emission levels would likely be achievable through use of the circulating fluidized bed combustor, utilizing the calcium carbonate present in the shale and requiring no sorbent or chemical additives. These values for stack emissions are well within World Bank standards.

1 The primary potential problem areas associated with the high ash content would be (1) bottom ash removal from the combustor, (2) high flow rate of recycle solids through the hot cyclone and return leg, (3) fly ash deposition and crosion of the convection tube banks, and (4) crosion of superheater tubes in the combustor.

Technical risks associatei with each of the proposed unit sizes are:

- The technical risk should be fairly low for a 20-MW demonstration plant. Eightecn plants of this size or laıger have been built by Ahlström or its subsidiaries; these plants have operated for a year or longer and have experienced availabilities of 95 percent or more.

$\square \quad$ The technical risk is moderate for a 50-MW plant. There is some operating experience with plants of this capacity firing coal or other low- to medium-ash fuels, but there is not yet any experience with high-ash fucl in plants this large.

- The technical risk is fairly high to build a 100-MW plant as the first unit. There is no plant this large operating or under construction which is designed to operate on high-ash fucl. 


\section{Projected Major Environmentai Effects of the Proposed Oil Shale-for-Power Project}

The major environmental effects of the preposed project revolve around control of the enormous auantitics of waste ash and overburden that would be generated from a 400-MW facility over a 25-30 year period. This control effor takes two forms: (1) control of the fugitive dust from mining, transporting, and processing the raw shale, and from disposal of the overburden and spent ash itself; and (2) control of the final disposition of the asit in terms of groundwater protection. There are minor concerns about general water availability. The concerns abo' $\iota$ dust control are both in terms of occupational safety and in terms of the surrounding residents and the mediate biota.

Jordan has no comprehensive environmental standards regulating industrial development such as the proposed oil shale plant. Absent comprehensive standards to guide industrial development, the GOJ relies on the Department of Environment in the Ministry of Interior to monitor and sometimes prevent the more egregious affronts to the environment. For major projects such as the proposed oil shale plant, the Department of the Environment would look to U.S. standards and World Bank guidelines in the interim until the country adopts its own regulatory stanciards and procedures.

The materials handling problems associated with moving vast quantities of rock and shale encompass several major environmental issues discussed below. The importance of the materials handling challenge is underscored in the Bechtel Group's project plan, where it is said that the need for a 50-MW step is more for answering questions centered on "Jesign issues for optimizing a 1(0)-MW plant, in particular matcrials flow, rather than any need to prove the technology feasibility." At peak, operation of the 40()-MW plant would generate approximately 1000 tonnes per hour of wetted residual ash for disposal.

Conclusions (for a 4(0)-MW, or "worst case," plant option) about the different key concerns are:

Ai" cualiiy and dust control

1. Although there has been extensive work undertaken in the U.S. public and private sectors to determine the degree of pollution control that must be used by managers of oil shale facilities to protect air quality, it is not possible to predict with confidence (with only a prefeasibility analysis) what precise impacts oil shalc mining and CFBC technology would have on air quality at various levels of shale oil production because no large-scale facilities exist to date and? because the proposed Jordanian project employs an innovative technology.

1 The incidence of respiratory diseases in other minerals s:traction industries indicates that exposure to the shale dusts and ashes at the Sultani project could be hazardous, potentially causing pneumoconiosis. The dust particles from the ash or from the raw oil shale fines would likely be low in silica content (except when cherty materials would be run through the boiicrs), therefore minimizing the threat of silicosis to plant and mine workers.

$\square$ Emissions of $\mathrm{SO}_{2}$ and $\mathrm{NO}_{\mathrm{x}}$ from the plant's boilers would likely be within international environmental and health protection siandards.

Groundwater protection

1 According to laboratory analyses of the leachate from the ash obtained from the test burn, ash disposal from the proposed facility may pose some risk of groundwater contamination, although

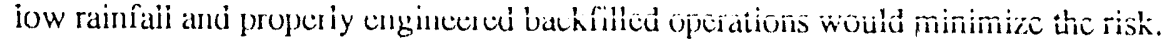


4 Jordan has, from the national perspective, very real water resource problems facing it. There are sigrificant current and future demands placed on the limited groundwater resources in the Sultani area. There would, however, likely be adequate groundwater of sufficient quality and at reasonable pumping depths for operation of the proposed plant/mine/waste disposal complex and for mecting future competing needs. The amount of water the GOJ has allocated for this plant is realistic and adequate.

- The Sultani area, while seemingly remote, will likely play a secondary role in helping major municipalities meet their municipal and industrial water needs as early as the late 1990s.

- Groundwater flow regimes in the Upper Wadi Mujib drainage suggest that leachate from the fly ash that enters the water table with inadequate filtration and dilution could cause drinking water problems with municipal users in Amman or Karak, now and increasingly in the future. Such an event would have a low probability of occurrence because of the area's low annual rainfall.

- Care must be taken in the fly ash waste disposal and reclamation engineering to optimize filtration of fly ash leachate through replaced overburden before it can infiltrate the Amman Wadi Sir groundwater.

- Monitoring wells and instrumentation or regular sampling would be necessary to assure that water safe from chromium and/or selenium contamination is being pumped from the Sultani and Qatraneh well fislds.

Land reclamation

a There is ample surface area available at the Sultani site for permanent storage of mine and plant wastes.

The Bechtel Group's land reclamation program proposed for the Sultani project is generally reasonable and responsible.

- Consideration of using the fly ash as an amendment to cement, asphalt, or other construction materials both as a profitable venture and as a means to decrease the quantities of materials to be disposed is premature at this stage of the analysis. Jordan has ample cement production now should into the forsecable future; viable new export markets for cement do not presently exist in the Middle East and are unlikely to open up in the near future. Transportation of a bulk material such as cement from the Sultani site to the port at Aqaba is currently too expensive for Jordanian cement to compete other international suppliers.

Erosion and sedimentation control

Erosion and sedimentation controls, both short-and long-term, during mining and waste disposal appear adequate.

Effect on the biota

- There are no likely significant impacts on plant or animal resources. 
Noise control

C. Controlled use of explosives (sequencing the charges), enclosing the crushing plant equipment, and through muffling truck and other mining equipment exhausts would likely minimize project noises. Permanent residential populations are too distant to be significantly affected. Scasonal shepherds and their herds move through the area, but would likely be fenced away from the project sufficiently to be unaffected by any project-related noises. Protection of workers would be the chief concem.

\section{Economic Feasibility of the Proposed Oil Shale-for-Power Project}

The economic analysis consists of a series of sensitivity studies for 20-MW, 50-MW, and 400-MW options, calculating the present values of net benefits and the internal rates of retum. For each plant size, the sensitivity studies included different assumptions about the operating characteristics of the plant: (1) capacity factor (50) percent, 60 percent, and 75 percent); ${ }^{2}$ (2) average price of electricity, $6.0 \notin / \mathrm{kWh}$ obtained by JEA in $1987^{3}$ and two alternatives (7.5 and $9.0 \mathrm{c/kWh}$ ); (3) mining/processing and residual ash disposal (a 50/50 and 80/20 debu/cquity ratio); 4 and (4) five capital expenditure scenarios, a base case provided by the Bechtel Group (noted Base) and four alternatives: an assumed 25 percent reduction in the base [Base(0.75)], a 25 percent increase [Base(1.25)], and 50 and 100 percent increases [Base(1.50) and Base(2.00)].5 A total of 270 sensitivity studies were conducted, 90 for each plant size. Four major conclusions were drawn from the study:

a The 20-MW plant is not an economically attractive option for Jordan under any of the scenarios considered in the study.

$0 \quad$ Under the tariff level currently in existence $(6 \mathrm{c} / \mathrm{kWh}$ in average revenues), the $50-\mathrm{MW}$ option is not economically attractive.

Under the current tariff level, the 400-MW option is attractive, contingent on assumptions made about the operating characteristics of the plant (Table S.1, discussed below).

$\square \quad$ Increasing JEA's current tariff level by 25 percent to $7.5 \mathrm{c} / \mathrm{kWh}$ makes the $50-\mathrm{MW}$ option economically attractive under only the most favorable operating assumptions (Table S.2, discussed below).

\footnotetext{
2The economic analysis here is not being conducted in tandem with a least cost capacity expansion planning model such as WASP III. An analysis such as this is beyond the scope of this prefeasibility assessment. In the event that a feasibility study is underiaken, a capacity expansion planning model would presumably be used. A model such as WASP would estimate the actual utilization (running time) of 20-, 50-, and 400-MW plant options based on minimizing system cost, given assumptions about (1) the operating characteristics of all other plants in JEA's system and the shale altematives, (2) projected fuel costs, and (3) forecasted electricity demand. In the present study, we simply assume three different capacity factors for each of the three plant sizes.

${ }^{3}$ Most recently, electricity prices were lowered for at least some customer classes as part of an austerity program announced by the government on November 6, 1988. See The Wall Street Journal and New Y'ork. Times, November 7, 1988.

4 The debt/equity ratios refer to the assumed capitalization of the mining/processing and residual ssh disposal operations. The $80 / 20 \mathrm{debt} / \mathrm{equity}$ assumption implies a lower cost of capital because the cost of debt is assumed smaller than the return required for tequity capital.

5 The \pm 25 percent scenarios are commonly used in sensitivity analyses. The +50 and +100 percent scenarios were included because estimates of capital expenditures for power plants are notoriously uncertain, especially when operating in foreign environment. Another important consideration is the foreign exchange needed to import materials for constructing the plant. Most recently, the Jordanian Dinar has been depreciating in intemational exchange markets, increasing the cost of importing materials for constructing power plants. On December 31, 1987, the Jordanian Dinar was worth \$3.04. The exchange rate stayed fairly stable during the first third of 1988 , equalling $\$ 2.95$ at the end of April 1988 . However, since then it has steadily declined to the point where on December 15, 1988 it was $\$ 2.13$.
} 
Table S.1 provides results for the 400-MW option, using the average revenue realized by JEA on its electricity sales in $1987(6 \not / \mathrm{kWh})$ and the most favorable assumption about the capital structure of the mining/processing and ash disposal operations (80/20 debt/equity ratio). The results show that, assuming a very low capital cost of the plant $[\mathrm{Base}(0.75)]$, the returns for the 60 and 75 percent capacity factor scenarios exceed JEA's opportunity cost of capital (which is 9 percent). The same is true under the Base scenario, assuming a 75 percent capacity factor. The results deteriorate substantially assuming higher capital expenditures on the plant.

Table S.1 Selected sensitivity results under current tariff structure ${ }^{\text {B }}$ by capacity factor and capital expenditure scenarios, 400-MW option (In percentages) $)^{b}$

\begin{tabular}{|c|c|c|c|c|c|}
\hline $\begin{array}{c}\text { Capacisy } \\
\text { Factor } \\
\end{array}$ & $\operatorname{Base}(0.75)$ & Basc & $\operatorname{Base}(1.25)$ & $\operatorname{Base}(1.50)$ & $\operatorname{Basc}(2.00)$ \\
\hline $75 \%$ & 13.41 & 9.77 & 7.33 & 5.54 & $3,(12$ \\
\hline $60 \%$ & 9.75 & 6.66 & 4.57 & 3.00 & 0.77 \\
\hline $50 \%$ & 7.01 & 4.30 & 2.43 & 1.02 & \\
\hline
\end{tabular}

Increasing average revenues improves the results. Table $S .2$ presents the results under the $7.5 \notin / \mathrm{kWh}$ assumption for both the 5()- and 40)(-MW options under different scenarios. Assuming that the average revenue received by JEA for its electricity sales were increased by 25 percent from $6.0 \% 1 \mathrm{WWh}$ to $7.5 \$ / \mathrm{kWh}$, Table S.2 shows that the 50-MW option would be economically attractive (IRR approaching or excecding 9 percent) only under the most favorable conditions: very low capital expenditures [Base $(0.75)]$ and high running rate $(75$ percent capacity factor). Because of scale economies, the results for the 4(0)-MW option are significantly better.

Assuming a 75 percent capacity factor, the simulated returns for the 400-MW option exceed 9 percent in all cases except under the most unfavorable assumption about the cost of the plant [Base(2.00)]. Assuming a 50) percent running rate, the returns approach or exceed 9 percent under the two most favorable assumptions about the cost of the plant.

The sensitivity analysis conducted in this study was undertaken at the individual firm level, that of JEA. There are three important extra-firm benefits - benefits that accrue to the economy or society as a whole - that must also be considered when evaluating the oil shale-for-power option. One of the most important is the forcign exchange savings resulting from using indigenous oil shalc in comparison with importing petrolcum or coal. Second, mining and processing the oil shate and disposing of the residual ash in comparison with importing coal and/or petroleum will have a significant net impact on employment in the country. Finally, there is an cnergy security benefit to Jordan in terms of using domestic energy in comparison to importing petrolcum. If the proposed plant were not cconomically attractive from the standpoint of the electricity authority, the premium that policymakers place on this difficult-10-quantify, energy security benefit - and the forcign exchange and employment bencfits - will determine if the plant should be built. 
Table S.2 Selected sensitivity results under an assumed tariff increasea, by capacity factor and capital expenditure scenarios, 50. and 400)-MW options (In percentages) b

\begin{tabular}{|c|c|c|c|c|c|c|c|c|c|c|}
\hline \multirow{2}{*}{$\begin{array}{l}\text { Capacity } \\
\text { Factor }\end{array}$} & \multicolumn{5}{|c|}{ 50 MWc } & \multicolumn{5}{|c|}{$4(1) \mathrm{MWC}$} \\
\hline & 0.75 & 1.00 & 1.25 & 1.50 & 2.00 & 0.75 & 1.00 & 1.25 & 1.50 & 2.00 \\
\hline $75 \%$ & 9.16 & 6.15 & 4.08 & 2.54 & 0.31 & 19.92 & 15.18 & 12.07 & 9.83 & 6.7 .3 \\
\hline 6()$\%$ & 5.92 & 3.32 & 1.51 & 0.14 & . & 15.43 & 11.46 & 8.82 & 6.90 & 4.20 \\
\hline $50 \%$ & 3.40 & 1.19 & . & & . & 12.17 & 8.72 & 6.40 & 4.69 & 2.27 \\
\hline
\end{tabular}

Source: Sec Chapter 9

a The current tariff structure yie!ds on average $6.0 \mathrm{c} / \mathrm{kWh}$ for clectricity sales, This scenario assumes that average revenues were increased by 25 pereent to $7.5 \mathrm{~d} / \mathrm{kWh}$. Also, the results include the $80 / 20$ debt/equity assumption for the capital structure of the mining/proc $r$ ing and spent ash disposal operations.

$b \wedge "$ " sig ,es that the internal rate of return is less than zero,

c Number headings refer to the five capital expenditure scenarios. 


\section{INTKODUCTION}

\subsection{HISTORY OF PROJECT}

In Spring 1986, the Bechtel Group, Inc. completed a cursory examination of building a 20-MW demonstration oil shale-for-power production plant in western Jordan. Based on this study, the U.S. Agency for International Development (AID) agreed to fund through the government of Jordan a more rigorous study of the potential for using oil shale for power production. ORNL was asked to participate in four areas of the study: (1) an assessment of the need for power, (2) a review of environmental aspects of the proposed plant and mining operations, (3) an assessment of the technical feasibility of using circulating fluidized bed (CFB) combustion technology, and (4) a financial and economic assessment of the project. The study was led by the Bechtel Group, Inc., under the AID Conventional Energy Technical Assistance Project, with input provided by the Pyropower Corporation of San Diego, CA (pilot test work and the boilcr designs and costs estimates) and Oak Ridge National Laboratory (ORNL). The Jordan Electricity Authority (JEA) anf the GOJ's Natural Resources Authority (NRA) provided the resources assessment data, the design basis criteria for the Sultani site, the 75-ton sample of oil shale used in the pilot plant test program, and a variety of cost records and demand projections for the power sector. ORNL also independently evaluated for AID the reasonableness and accuracy of the Bechtel and Pyropower conclusions. The Bechtel Group assembled all of these contributions into a 6-volume report published in May 1989.1 This document is an account of the ORNL contributions to the entire project and to the Bechtel-coordinated document.

The first major activity of the study was the shipment of a sample of the Sultani oil shale to Pyropower's parent company, the Ahlstrom Corporation, in Finland for a test burn under a varicty of combustion environments. The results of the test burn proved encouraging. Eleven tons of the residual ash were shipped to ORNL. for testing and evaluation of the ash's potential for use as an amendment to construction or paving materials. Tests for carcinogenic, acidity, caustic, or other residual ash characteristics potentially hazardous to human health or the environment were also encouraging (Chapter 7) in light of negative findings. Simultancous to the testing of the ash, a team visited Jordan in April 1988 to discuss enginecring, cnvironmental, and cconomic aspects of the proposed plant. The team consisted of representatives of the Bechtel Group, Pyropower, AID's Office of Energy in Washington, and ORNL.

\subsection{PAST OIL SHALE STUDIES IN JORDAN}

Industries involved in oil shale have existed in 14 countries at one time or another, some existing prior to the discovery of oil in 1859. Known oil shale deposits exist in many countries with the full extent of reserves in cach as yet unknown.

\subsubsection{Global Use of Oil Shale}

At present, commercial quantities of oil shale are mined and used for power production through direct combustion in the Soviet Union, China, and Sweden. In Sweden, however, shale is used primarily for uranium preparation. The Soviet Union is the leader in utilizing oil shaie directly in boilers for power production. Besides power production, the Soviet Union uses oil shale to obtain petroleum feed stocks and for combined power generation and industrial processing. Annual production of oil shale in the Soviet Union is 35 million tons, with three-quarters of this used as a fuel input for power production. The power plants using oil shale are.

\footnotetext{
1 Prefeasibility Study: Oil Shale Utilization for Power Production in the llashemite Kingdom of Jordan, Volumes I.VI, A repon of the Office of Energy, Bureau for Science and Technology, U.S. Agency for International Development, prepared by Bechtel National, Inc., 1601 North Kent Street, Suite 914, Arlington, Virginia 22209, USA, Report No. 89-02, May 1989.
} 
located in the Baltic Republics. Two of the largest are the Estonian Power Plant (1600 MW) and the Pribaltiiskaya Plant (1450 MW).

Serious U.S, experience with exploitation of the vast U.S. reserves of oil shale (an estimated 630 billion bbls of oil) began in the late 1970s with the establishment of the Synfuels Corporation. Created by the U.S. Congress under the U.S. Energy Security Act, the Synfuels Corporation subsidized development of new technologies for exploiting unconventional fuel sources. After the price of oil peaked in 1981, the impetus to seck alternative or innovative sources of fucls waned and Corgress eventually shut down the Corporation in 1985. To maintain progress after that time in understanding and surmounting the obstacles to stecessful commercialization of these technologies, Congress guarantecd price supports for iucls $?$ ing produced from four plants, one an oil shale plant producing liquid fucl through a relort process. The Unocal Corporation's Parachute Creck plant in Colorado has produced more than 600,000 bbls of synthetic oil, while so far reaching only half of its 10,000 bbls/d production capacity. The U.S. government's subsidy to Unocal (it currently guarantecs Unocal $\$ 46.50 / \mathrm{bbl}$ ) amounted to $\$ 17.4$ million in 1987 , and will extend to $\$ 4(0)$ million or 10 years, whichever comes first.

\subsubsection{Jordanian Experience with Oil Shale}

Jordan's oil shale reserves are estimated to be more than 10 billion tons. The use of shale in Jordan dates back to the beginning of this century. A production plant using Jordanian oil shale to fecd a primitive retorting process provided oil fuel for lecomotives prior to World War I - before such processes were even tried in Europe or the United States.

More recently, studies of the fo)!cntial for using the El Lajjun deposit (Figure 1.1) as a source of petrolcum fucls were started in 1968 , by the Natural Resources Authority (NRA) of the Government of Jordan (GOJ). The studics involved core drilling and laboratory analyses using the Fischer Assay procedure for determining oil yields. Other analyses included determination of the inorganic constituer of the ore and its calorific value and identification of trace elements. NRA consulted British, West German, and U.S. oil shale experts in conjunction with conducting the studies. The studies were terminated in 1969 becaluse the estimated cost of oil shale processing greatly exceded the then current and projected cost of using imported petroleum. In the 1968 69 period, 53 borcholes were drilled.

The NRA rcopened the investigation of the El Lajjun deposit in carly 1979 because of the precipitous increase in the cost of imported petroleum and Jordan's rapidly increasing petrolcum needs. The NRA's current program at El Lajjun - an assessment of the retort potential of the shale oil - is being assisted by West Cicrmany. In the 1980), the NRA began to study the Sultani site in detail for the feasibility of using oil shale in a direct combustion process to provide power generation in Jordan.

\subsection{LOCATION OF PROPOSEN OIL SHALE PLANT(S)}

The Sultani site is located approximatcly $1(22 \mathrm{~km}$ south of Amman, the capital of Jordan, just off the main north-south Desert Highway (see Figure 1.1). The highway connects Jordan's northern neighbors with Mecca, the Holy City of the Islamic world The proposed oil shale plant, although secmingly in a remote location, would have high visibility in Jerdan.

\subsection{ORGANIZATION OF REPOR'T}

This draft prefcasibility assessment of the proposed oil shale power plant in Jordan contains cight additional chapters. The next chapter presents an overvicw of the Jordanian encrgy sector, including primary energy sources, encrgy conversion facilities, and final energy demand. It also discusses regulatory institutions in the energy sector of the economy. Section 3 addresses the need for power in the Jordanian economy over the next 
two decades. The discussion includes a descriptinn of electricity consumption over the past decade and two sets of forecasts of electricity demand. Three complicating factors in evaluating future electricity demand are then discussed: (1) the possibility of interconnections with - and power exports to - neighboring Arab countries; (2) the potential effect that prics- and nonprice-induced demand-side management measures could have on electricity demand; and (3) the fuitur, economic growth of the economy, including growth prospects for major industrial electricity consumers. Given these uncertainties in cvaluating future electricity demand, three forecasts of load growth are presented and the implied amount of additional generating capacity required in Jordan to service that load growth is computed.

The fourth chapter discusses Jordan's indigenous energy resources which could potentially be used to meet future power requirements. The candidates are crude oil, natural gas, shale, and renewables. Chapters 5 and 6 present technical aspects of the proposed plant. They include a description of the circulating fluidized bed (CFB) combustion technology that would be used in the proposed plant(s) and brief technical descriptions of the plant and mining operations. Much of what was riginally Chapter 6 has been withheld because of its proprictary nature. Details may be pursued with the Pyropower Corporation. Chapter 7 discusses potential environmental effects of the plant and mine. Of particular importance here awe discussions of the results of the chemical analyses of the residual ash produced from burning the shale, of the availability of water, and of the relationship of ash leachate to groundwater resources. Chapter 8 provides a technical risk assessment of the proposed CFB combustion technology; it is in part based on observing the technology in operation at Colorado UTE, a rural electric cooperative in the United States. The final section contains a financial/economic analysis of the proposed oil shate plant(s), including sensitivity studies of 2()-MW, 50-MW, and 40)-MW options. 


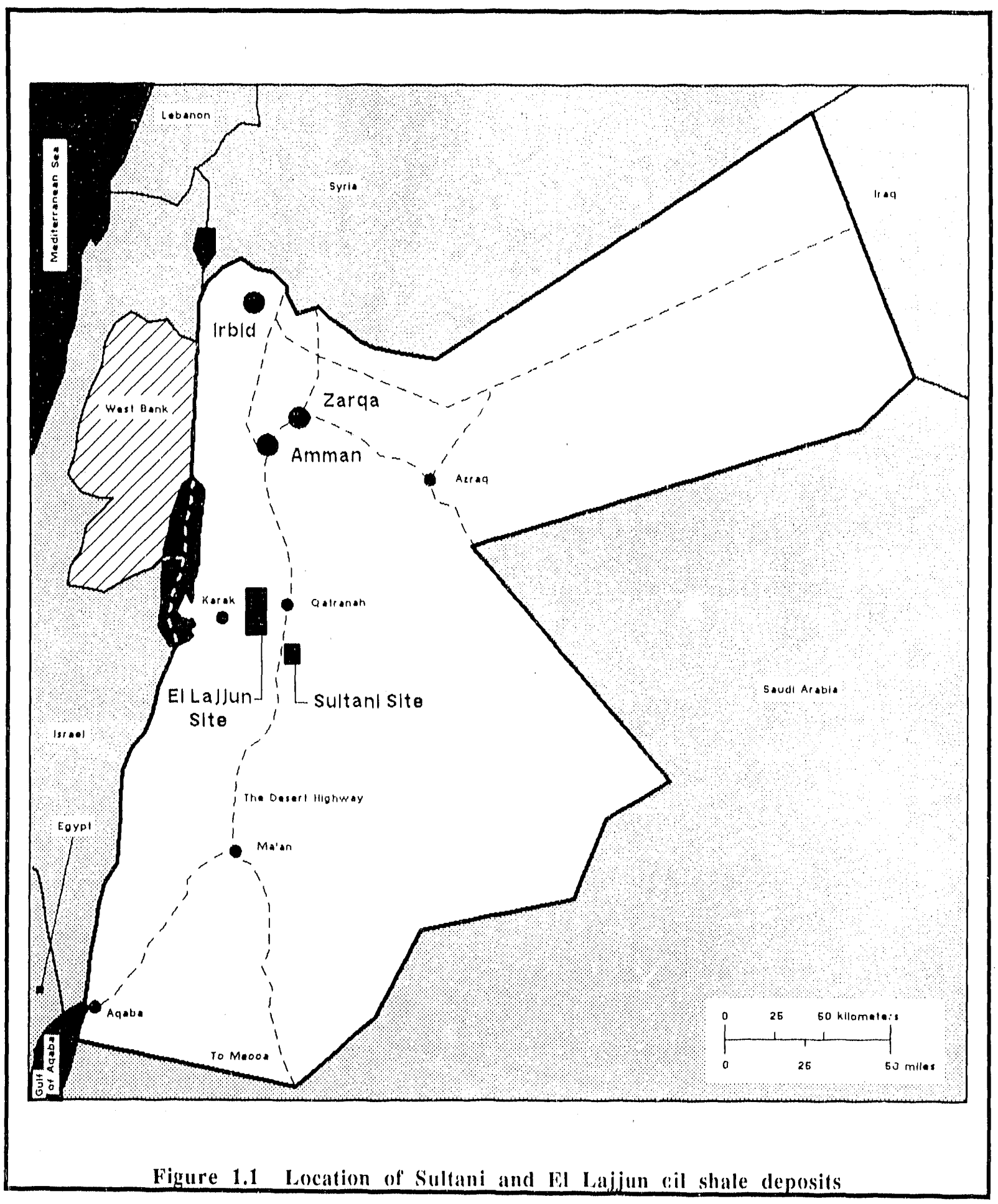




\section{AN OVERVIEW OF THE JORDANIAN ENERGY SECTOR}

The most salient characteristic of the Jordanian energy cconomy is its historical reliance on imported petroleum. With the exception of a nominal amount of hydropower and renewable energy resoures, Jordan has historically relied on Middle Eastern oil-exporting countries for its encrgy. Jordan does have indigenous energy resources, but it did not begin intensively studying the extent and economic feasibility of using them until a decade ago. 1 A precipitous increase in Jordan's fucl import bill in the 197()s and carly 198()s - caused by the rapid increase in the international price of petroleum and jordan's robust economy - led policymakers to give indigenous energy development a high priority in economic planning. Emerging technologies have also played a role in studying the feasibility of using Jordan's energy resources. That is especially true for oil shale. The primary reason for this study - examining the feasibility of using oil shale for power gencration using a circulating fluidized bed combusion process - was prompted by the emergence of an improved boiler technology for burning hight-as.' fuels of relatively low energy content. Besides oil shale, Jordan has a number of other potential energy resources which could signiticantly lessen the historical forcign exchange burden of oil imports. Although not presently tapped to any significant extent, there is a promise for the use of renewable energy in Jordan. More important, recent discoveries of crude petroleum and natural gas offer the hope of even more significant forcign exchange savings.

This chapter lays the foundation for the remainder of the study by providing a background on the Jordaniun energy sector, emphasizing energy institutions and capacity. Figure 2.1 provides a schematic representation of the Jordanian energy sector as of the end of $1987 . .^{2}$ Sourecs of primary energy include petroleum and a limited hydropower potential. The Jordan Petrolcum Refining Company (JPRC) is the sole user of the crude oil imported by the government, refining it and selling products to cnd users. ${ }^{3}$ JPRC also sells diesel and fucl oil for electricity production to (1) the Jordan Electricity Authority (JEA), the primary generator of electricity in the country, (2) the Irbid District Electric Company (IDECO), (3) municipalitics, and (4) various industrial users for self power generation. Although JEA sells some power to end users, it sells a large portion of the power it produces to the primary distributors in the country - IDECO and the Jordan Electric Power Company (JEPCO). Besides generating their own power, large inclustrial users also purchase power from the central grid. The largest end user of energy is the transport sector. Each of the three activities depicted in Figure 2.1 (primary energy supply, conversion, and consumption) is discussed in detail bolow.

\subsection{PRIMARY ENERGY SOURCES}

Table 2.1 displays the supply of primary energy to Jordan for 1976 and 1986, divided between domestic sources and foreign imports. Total primary cnergy consumption increased by more than two and one-half times in the decade from 1976 to 1986 (from 1.1 million TOE to 3.0 million TOE), reflecting substantial increases in total economic activity in the country.

\footnotetext{
1 Jordan's oil shale was used to a limited extent prior to World War I. Oil and gas exploration began after World War II, but the intemational oil companies abandoned Jordan because they belicved that it did not have sufficiently large ficlds to rival those of other Middle Eastem countries. A further discussion of Jordan's indigenous energy resources is provided in Chapter 4.

2 For elarity of presentation, the use of rencwables has been excluded from Figure 2.1 .

3 A portion of Jordan's refined petroleum requirements is not attributable to the output of JPRC, but is imponted.
} 


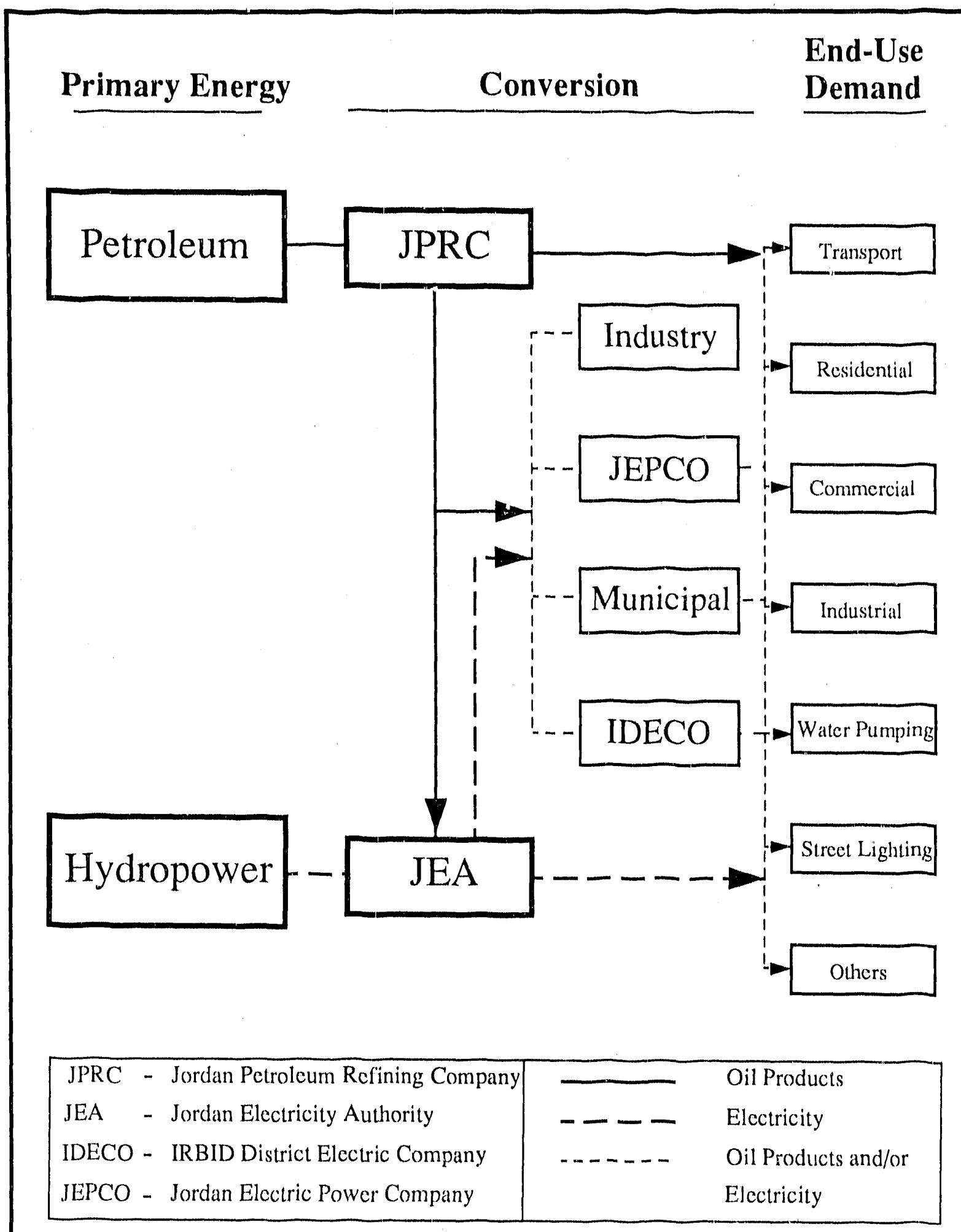

Figure 2.1 Schematic representation of the Jordanian energy sector 
Table 2.1 Primary energy supply in Jordan, 1976 and 1986 (amounts in thousands TOE)

\begin{tabular}{|c|c|c|c|c|}
\hline \multirow[b]{2}{*}{ Source } & \multicolumn{2}{|c|}{1976} & \multicolumn{2}{|c|}{1986} \\
\hline & Amount & $\%$ & Amount & $\%$ \\
\hline Domestic: & & & & \\
\hline Crude Oil & () & 0.0 & 1.5 & 0.5 \\
\hline Hyclio & () & 0.0 & 31 & 1.0 \\
\hline Subtotal & () & 0.0 & 46 & 1.5 \\
\hline Foreign: & & & & \\
\hline Crude Oil & 1,112 & $10(0.0$ & 2,282 & 76.9 \\
\hline Fucl Oil & 0 & 0.0 & 582 & 19.6 \\
\hline Dicsel & () & 0.0 & 51 & 1.7 \\
\hline L.PG & () & (). 0 & 8 & 0.3 \\
\hline Subtotal & 1,112 & 100.0 & 2,923 & 98.5 \\
\hline Total Supply & 1,112 & $10(0.0$ & 2,969 & $10(0.0$ \\
\hline
\end{tabular}

Source: World Bank and Government of Jordan, Ministry of Energy and Mineral Resources

In 1976, all primary energy supply was oblained from forcign soures. Domestic sources of encrgy aceounted for only 1.5 percent of primary energy requirements in 1986. Of this amount, a nominal anount of crude oil production from the Amzah region accounted for 0.5 percent and hydroclectric production only $1 .()$ percent of primary domestic energy supply. Hydropower potential in Jordan is limited to $24 \mathrm{MW}$ ( $87 \mathrm{GWh} / \mathrm{y}$ ); an additional $7 \mathrm{MW}$ are currently developed: $4 \mathrm{MW}$ at the King Talal dam on the Zarga River and $3 \mathrm{MW}$ of the 20 MW potential at the Mayarin Dam on the Yarmuk River. Foreign imports of petroleum accounted for the majority of primary encrgy supply in 1986 , comprising 98.5 pereent of the total. Crude oil imports accounted for 76.9 percent of total supply, while fucl oil accounted for 19.6 percent. The remainder was provided by imports of diesel and LPG.

\subsection{ENERGY CONVERSION}

The petroleum sector in Jordan involves JPRC and the government. JPRC is a privately owned firm. The, government, however, holds 12 percent of its stock. It operates the sole petroleum refinery in the country, and is located $35 \mathrm{~km}$ north of Amman. It has sole responsibility for refining the crude oil purchased for it by the government. It is also responsible for distributing and marketing all of the refined products. JPRC is regulaled by the Ministry of Energy and Mineral Resources (MEMR) in accordance with a concessionatry agreement which ensures that the company carns a fair return on investment.

The power sector as it is presently organized in Jordan is a relatively recent phenomenon. JEA was established by enactment of an electricity law in 1967. The purpose of the legislation was to centralize responsibility for power provision, with JEA acting as the coordinator. Under the legislation, JEA could designate existing power stations to operate under its direction, acyuire the stations if it was deemed appropriate, and abandon uneconomic power generation facilities. However, JEA did not initially function as a utility. It acted as a conduit for government loans for power development to the existing electrie distribution companies. The role of JEA was delineated in 1976 with enactment of the Ciencral Electricity Law. According, to the statute, JEA is a financially 
and administratively autonomous electric utility. Its responsibilities include power generation, transmission, and distribution in addition to its responsibility as regulator of power consumption in the country. JEA is governed by an eight-member board appointed by the government and responsible to it for formulating JEA's general policy direction, including the setting of tarif's. JEA is also responsible for the formulation of the national rural electrification program in consultation with MEMR and the Ministry of Planning (MOP).

The iegislation allows local distribution systems to operate and to be owned by private investors, but JEA regulates the distribution utilities. JEA, huwever, may take over the local distribution systems through mutual agreement, subject to the government's approval.

In addition to JEA, which sells some power at low voltage hesides its bulk sales to distributors, there are presently two distribution companies operating through concessions from the government. JEPCO is a private company, owned by the public ( 77 percent), JEA (13 percent), and the municipalities (10 percent). It has responsibility for electricity distribution ir the city of Amman and its environs. ${ }^{4}$ IDECO is a semi-private company owned by JEA (46.5 percent), the municipalities of the Irbid governate ( 42.5 percent), and private investors (11 percent). It is responsible for fower distribution in the governates of Irbid and Mafrag, with the exception of the Jordan Valley area. ${ }^{5}$

The government agency presently responsible for the energy sector is the MEMR. Created in November 1984, it formulates the overall energy strategy of the country, including pricing policies in the petroleum and power subsectors. It is also responsible for coordinating activities in the energy sector.

As depicted in Figure 2.1, there are a number of non-utility generators of power in Jordan, including private industrial generators, mining interests, and municipalities. Table 2.2 shows the extent of private ownership of power production faciitities in Jordan at the end of 1987 by ownership type and prime mover. Of the $979 \mathrm{MW}$ of total capacity in the country, JEA owned $869 \mathrm{MW}$ or 88.8 percent of the total in 1987. Of the other power generators in Jordan, the diammonium phosphate fertilizer company had the largest amount of capacity, $44 \mathrm{MW}$ in 1987. Two of the other electricity generators were interconnected with the national grid in 1987: the potash mine and IDECO. Their $21 \mathrm{MW}$ of generating capacity combined with $869 \mathrm{MW}$ owned by JEA totals $890 \mathrm{MW}$ of capacity on the interconnected, national grid.

\footnotetext{
4 JEPCO used to be both the largest power gencrator and distributor in Jordan prior to formation of JEA. JEPCO was formed in 1963 as a result of a merger between Jordan Central Electric Company (distributor in the Zarqa concessionary area) and the Transjordan Fleceric Power Company, Lid. The latter company was formed in 1947 as a result of the unification of several small electric nower companies which were operating independently in Amman and its environs.

5 IDECO was created as a private company in Irbid in 1957. In 1961, IDECO was converted to a public company and granted its present concession.
} 
Table 2.2 Installed electric generating capacity in Jordan by owner and prime mover, December 31, 1987

\begin{tabular}{|c|c|c|c|c|c|}
\hline Category & Steam & Gas & Diesel & Hydro & Total \\
\hline Total & 696 & 182 & 94 & 7 & 979 \\
\hline JEA & 623 & 182 & 57 & 7 & 869 \\
\hline Others: & 73 & 0 & 37 & 0 & 110 \\
\hline Refinery & 14 & & 2 & & 16 \\
\hline Arab Potasha & 15 & & & & 15 \\
\hline Fertilizer & 44 & & & & 44 \\
\hline IDECOa & & & & 6 & 6 \\
\hline Cement (Ferheis Plant) & & & & 9 & 9 \\
\hline El Hasa Phosphate & & & & 12 & 12 \\
\hline Municipalities & & & & 8 & 8 \\
\hline
\end{tabular}

Source: Jordi, Electric Authority, Annual Report, 1987

a Pan of the interconnected national power system

\subsection{FINAL ENERGY CONSUMPTION}

Table 2.3 provides the end-use consumption and percentage composition of all energy consumed in 1976 and 1986 by sector. Energy use in the transport sector $-475,000$ TOE in 1976 and 1.11 million TOE in $1986-$ accounted for the most energy consumed, comprising over one-half of total energy consumption. The household sector consumed 15.1 percent of all energy in 1986, down from 20.7 percent in 1976. The industrial sector consumed less than 20 percent. However, as the next chapter shows, the industrial sector accounted for nearly 40 percent of total end-use electricity consumption in Jordan in 1987.

Table 2.3 End-use energy consumption in Jordan, 1976 and 1986 (amounts in thousands of TOE)

\begin{tabular}{|c|c|c|c|c|}
\hline \multirow[b]{2}{*}{ Sector } & \multicolumn{2}{|c|}{1976} & \multicolumn{2}{|c|}{1986} \\
\hline & Amount & $\%$ & Amount & $\%$ \\
\hline Household & 189 & 20.7 & 330 & 15.1 \\
\hline Transport & 475 & 52.1 & 1,110 & 50.7 \\
\hline Industry & 184 & 20.2 & 421 & 19.2 \\
\hline Other & 64 & 7.0 & 195 & 8.9 \\
\hline Nonenergy Use & 0 & 0.0 & 132 & 6.9 \\
\hline Total & 912 & 100.0 & 2,189 & 100.0 \\
\hline
\end{tabular}

Source: World Bank and Government of Jordan, Ministry of Energy and Mineral Resources 


\section{THE NEED FOR POWER}

The scope of this prefeasibility study does not encomplass developing an electricity demand forecast for the Jordanian electricity subsector. However, two electricity demand forecasts have recently been prepared: (1) the annual Jordan Electricity Authority (JEA) forecast developeci as part of its planning process and (2) projections of electricity demand made by Meta Systems/Hagler-Bailly/Bechtel in March 1988.1 These two electricity demand projections will serve as the basis of the discussion on the need for power.

Before addressing the question of future electricity requirements in Jordan, however, it is instructive to look at historical electricity consumption. Electricity consumption from 1975 through 1987 is the topic of the next section. After reviewing the clectricity demand projections of JEA and the Meta Systems et al. study in Section 3.2 , the discussion turns to complicating factors in assessing the electricity demand forecasts in the subsequent section. Economic projections are notoriously uncertain, contingent on specifying assumptions about the future state of domestic and international economies. Section 3.3 discusses some complicating factors relevant to assessing the future electricity growth in the Jordanian economy. These factors include (1) actual and planned power interconnections between Jordan and neighboring Arab countries, thereby creating the possibility of increased power exports by Jordan; (2) more efficient use of electricity created by both price- and nonpriceinduced demand-side management programs; and (3) future growth of the Jordanian economy. The latter includes a discussion of the major industrial users of electricity. The chapter concludes with an evaluation of the need for power in Section 3.4.

\subsection{HISTORICAL GROWTH IN ELECTRICITY CONSUMPTION}

Table 3.1 summarizes total clectricity consumption in Jordan for sclected years from 1975 through 1987 and the percentage composition by sector. Total electricity consumption increased more than ten-fold from 1975 through 1987, progressing from $236 \mathrm{GWh}$ in 1975 to 2,668 $\mathrm{GWh}$ in 1987. On a sectoral basis, electricity consumption in the residential sector accounted for a little less than 4() pereent of the total in 1975, declining to 28.5 percent in 1987. The industrial sector is the largest user of electricity, increasing from 19.1 percent of total elec 'icity consumption in 1975 to almost 40 percent in 1987. Electricity used to plimp water increased significantly in the past three years. In 1985, water pumps accounted for $10 .($ percent of total electricity consumption. The percentage climbed to 15.6 two years later.

The significance of electricity use for water pumping is further quantificd in Table 3.2. The table provides the average annual percentage growth in electricity consumption by sector and in total over the 1975-1987 period, by various subperiods. Over the total 12-year period from 1975 to 1987 , the average annual growth in electricity was 20.2 percent. The industrial sector grew the fastest, increasing at an annual rate of 26.4 percent over the period. The rate of increase of electricity use for water pumping was the second fastest, increasing at 22.2 percent per year.

Disaggregating these results into different time periods, however, shows a declining trend in electricity growth. Total electricity consumption grew the fastest in the 1975-1980 period. It increased at an annual rate of more than 26 percent over that period, spurred in large measure by 38.3 percent average annual growth in the industrial sector.

In the 1980s, growth has slowed. In the first five years of the decade, the growth in total consumption declined to 17.9 percent per annum. In the most recent two years, growth was under 11 percent. Growth in the industrial sector slowed considerably, declining from 38.3 percent in the last half of the 1970 s to 8.2 percent in

\footnotetext{
1 Meta Systems, Hagler-Bailly, Bechtel, Report on Long Term Energy Policy and Investment, March 22, 1988.
} 
the 1985-1987 period. ${ }^{2}$ The rate of growth in the residential and commercial sectors also declined from historical levels in the most recent two-year period.

Table 3.1 Jordanian electricity consumption, amount and percentage composition by sector, selected years, 1975-1987

\begin{tabular}{cccccccc}
\hline & & \multicolumn{6}{c}{ Percentage Composition by Scctor } \\
\cline { 3 - 8 } & Total & & & & Water & Strect & \\
Ycar & (GWh) & Domestic & Commercial & Industrial & Pumps & Lighting & Other \\
\hline 1975 & 236 & 39.0 & 16.9 & 19.1 & 12.3 & 4.2 & 8.5 \\
1980 & 877 & 36.6 & 12.2 & 34.9 & 8.7 & 1.8 & 5.8 \\
1985 & 2,151 & 30.4 & 12.5 & 42.0 & 10.0 & 2.1 & 3.0 \\
1987 & 2,668 & 28.5 & 10.6 & 39.9 & 15.6 & 2.5 & 2.9 \\
\hline
\end{tabular}

Source: Jordan Blectricity Authority, Annual Report, various years.

Table 3.2 Jordanian electricity consumption, average annual growth by subperiods (percent)

\begin{tabular}{|c|c|c|c|c|c|c|c|}
\hline Year & Domestic & Commercial & Industrial & $\begin{array}{l}\text { Water } \\
\text { Pumps }\end{array}$ & $\begin{array}{c}\text { Street } \\
\text { Lighting }\end{array}$ & Other & Total \\
\hline $1975-87$ & 17.6 & 16.3 & 26.4 & 22.2 & 15.7 & 11.1 & 20.2 \\
\hline $1975-80$ & 25.0 & 19.7 & 38.3 & 19.3 & 9.4 & 18.7 & 26.3 \\
\hline $1980-85$ & 14.3 & 18.4 & 21.6 & 20.8 & 21.1 & 4.5 & 17.9 \\
\hline $1985-87$ & 7.4 & 2.9 & 8.2 & 33.1 & 18.0 & 8.6 & 10.8 \\
\hline
\end{tabular}

Source: Computed from Jordan Electricily Authority, Annual Keport, various years.

The annual rate of growth of electricity use for water pumping, however, has increased over the past decade. From 1985-1987, electricity use increased by more than 33 percent per annum. Electricity use for water pumping is expected to grow in the future. Water resources are becoming increasingly scarce in the Amman region. North Jordan has at least 95 percent of the country's population (Amman accounts for 70 percent of the country's water demand), but has only 55 percent of its surface area. Groundwater and surface water supplies in the North are extensive, but are insufficient to meet all of the competing demands (irrigation, domestic, and industrial applications). Groundwater resources in the southeastern part of the country are extensive, but remote from demand centers. Water requirements for irrigation in 2015 are estimated to be only 6 to 15 percent higher than the $1986 \mathrm{level}$; however, municipal water requirements are expected to triple over the next 30 years. Higher usage levels and remoteness of supplies portend larger electricity requirements for pumping. ${ }^{3}$

Especially important for a need for power analysis is the peak load of the system. In Jordan, the peak is usually in September. Table 3.3 provides the peak load and its growth for selected years from 1975 through 1987. The peak grew at an average annual rate of 16.0 percent from 1975-80, reflecting the rapid increase in electricity growth, but substantially below the clectricity demand growth rate of 26.3 percent over the same period (see

2 The industrial sector will be discussed in greatcr detail in the nexi secitum.

3 Issues associated with water availability are discussed at length in Chapter 7. 
Table 3.2). From 1980-85, the growth rate in peak load increased slightly. Most recently, peak load growth slowed considerably. From 1985-87, it grew at an average annual rate of 11.1 pereent. However, the pereentage growth in peak in 1987 was only 6.1 percent.

Table 3.3 Peak electricity load in Jordan, selected years, 1975-1987

\begin{tabular}{|c|c|c|}
\hline Year & $\begin{array}{l}\text { Pcaka } \\
(\mathrm{MW})\end{array}$ & $\begin{array}{l}\text { Grr.wthb } \\
\text { (perent) }\end{array}$ \\
\hline 1975 & 88 & \multirow[b]{2}{*}{16.0} \\
\hline 1980 & 196 & \\
\hline & & 17.7 \\
\hline $1985^{\circ}$ & 475 & \multirow{2}{*}{11.1} \\
\hline & & \\
\hline
\end{tabular}

The combination of $979 \mathrm{MW}$ of installed capacity (Table 2.2) and a peak load of $593 \mathrm{MW}$ (Table 3.3) for 1987 indicates a significant reserve margin on Jordan's electric system. 4

\subsection{FORECASTS OF ELECTRICITY DEMAND}

As part of its corporate planning effort, JEA forecasts electricity demand annually. The methodology used to forecast electricity demand by JEA does not involve executing an energy demand model integrated with a model of the rest of the economy. Rather, it is a sector-specific approach, taking the forecast results of six sectors and then aggregating to tolal electricity demand. The six sectors are domestic, commercial, industrial, water pumping, institutions, and others. Within each of these sectors different methodologies are used to forecast demand. The three most common are simple extrapolation of historical trends, market surveys, and specification of econometric models. Extrapolation involves examining historical trends and projecting into the future. A market survey approach is used for bulk-supply industrial customers. The difference between electricity needs and self-generation by these customers is determined by on-site visits and interviews with knowledgeable engineers. An econometric approach consists of specifying equations with independent variables theorized to influence the consumption of electricity for specific sectors (electricity price, income).

Table 3.4 summarizes the annual forecasts of demand made in consecutive years from 1982 to the most current period, 1987. The table highlights the declining growth rates projected by JEA over the decade of the 1980s. In 1982, forecasted annual growth was 9.2 pereent over the $1985-2000$ period, reaching 9,935 GWh of consumption in the year $20(0)$. However, since that period, the forecasted growth rate over the $1985-2000$ period has declined with the exception of the most recent forecast made in 1987. The 1987 forecast shows electricity consumption increasing at an average annual rate of 6.9 percent from 1985 to $2(0) 0$, reaching $7,639 \mathrm{GWh}$ in the year 2000 .

\footnotetext{
4 The reason for this large margin could be a lack of demand, a capacity requirement to cover nonscheduled downtime on the system, or a combination of the two. It is nor posstble to determine from data made available to the study team what the specific reason(s) were.
} 
Beside the forecasts of electricity demand provided by JEA, there have been a number of other demand studies conducte'. The most recent, completed in March 1988, was undertaken by a Meta Systems/Hagler Bailly/B $/$ chtel team. The study team used an energy-economy model which was developed carlier, modified, and then transferred to MEMR. It is a general equilibrium model of the Jordanian economy, capturing the interrelationships between the energy subsectors in Jordan and other sectors of the Jordanian economy. ${ }^{5}$

Use of the model requires a number of exogenous assumptions about economic conditions both external to Jordan (the world price of oil, for example) and internal to the Jordanian economy such as policy instruments (tax policy, for example). The authors posited a number of assumptions to project energy demand under 12 scenarios, including assumptions about both domestic and international conditions to the year 2000 . Their base calse scenario was developed by the project team and various ministries of government to reflect what the planners believe is a reasonable set of domestic and foreign conditions that Jordan will confront over the forecasting horizon.

Table 3.4 Jordan Electricity Authority summary of electricity denand forecasts, 1982-1987 (percent)

\begin{tabular}{|c|c|c|c|c|c|}
\hline Ycara & $198.5-1990$ & $199(0-1995$ & $1995-20(7)$ & $2(x)(0)-2(x) 5$ & $198.5-2(k) 0$ \\
\hline 1982 & 11.7 & 9.1 & 7.0 & & 9.2 \\
\hline 1983 & 9.9 & 8.8 & 6.9 & & 8.5 \\
\hline 1984 & 10.7 & 7.7 & 6.8 & & 8.4 \\
\hline 1985 & 9.9 & 6.8 & 5.8 & & 7.5 \\
\hline $1986^{\circ}$ & 9.1 & 5.7 & 4.2 & 3.9 & 6.1 \\
\hline $1987 \mathrm{c}$ & 9.7 & 6.9 & 5.2 & 4.3 & 6.9 \\
\hline
\end{tabular}

Source: Computed from Jordan lilectricity Authority, Annual Report, various years

athe year of the annual report in which the folceast appeared

b Includes one actual year and four forecasted years. The 15 -year forecast from $1985-20() 0$ includes forecasts for 14 years from 1986 through 2000 .

c Includes two years actual and three forecasted years. The 15 -year forecast from 1985 -200) includes forecasts for 13 years from 1987 through $20(0)$.

Table 3.5 summarizes the forecasts of electricity demand from the base case and, for the sake of comparison, presents JEA's most recent forecast of electricity demand over the same period that was provided in Table 3.4. Table 3.5 shows a significant difference between the most recent JEA forecast and that of Meta Systems et al. Over the 1986-200) planning horizon, JEA projected a 6.9 pereent average annual groweth rate in electricity consumption in comparison with a forecast by Meta Systems et al. of 4.2 percent. The growth rates in subperiods presented in Table 3.5 are correspondingly different.

Besides the base case scenario presented in Table 3.5, the Meta Systems et al. study projected electricity demand under 11 other scenarios, comparing the results of different exogenous assumptions on future macrocenomic conditions, world oil prices, and the treatment of domestic energy prices (adjusting to changing international prices or not). The highest annual growth rate of electricity demand over the 1986-20(K) period under any of these scenarios was 5.3 percent. In this particular scenario, the most optimistic assumptions about future macroeconomic conditions were invoked, a gradual increase in the international price of petroleum was assumed, and demestic energy prices were assumed to remain constant. Under the worst case scenario for electricity demand growth, the base case macrocconomic assumptions were assumed, there were fluctuating changes in the

\footnotetext{
$5 \mathrm{~A}$ detailed description of the model is beyond the scope of this study. The interested reader is referred to Energy Economy Model of Jordan: Impact Analysis Using the Model, Mcta Systems, Inc., Study 117, March 1988.
} 
international price of petroleum, and domestic energy prices were adjusted instantancously to reflect the international price changes. In this scenario, the average annual growth rate in electricity demand over the 19862000 period was projected to be 3.6 pereent.

Table 3.5 Comparison of electricity demand forecasts, 1986-2'00 (percent)

\begin{tabular}{|c|c|c|c|}
\hline Source & $1986-1990$ & $199(0-2 x)(0$ & $1986-20(x)$ \\
\hline $\mathrm{JEA}^{\mathrm{a}}$ & 9.7 & 6.0 & 6.9 \\
\hline Meta Systems, et al. & 4.9 & 3.9 & 4.2 \\
\hline
\end{tabular}

\subsection{COMPLICATING FACTORS IN ASSESSING FUTURE ELECIRICITY DEMAND}

Encrgy demand forecasts are replete with assumptions on future economic conditions which are highly uncertain. The preceding forecasts of electricity demand in Jordan are no exception. There are a number of especially uncertain aspects of the Jordanian economy and power subsector which must be considered when evaluating future power requirements. With respect to electricity demand, three are important. First, potential further interconnections of the national power systems of Jordan, Syria, Egypt, and Saudi Arabia could significantly affect electricity sales. Currently, Jordan exports power only to Syria. Another area of uncertainty is the extent to which demand-side management programs (including price reform and conservation activities) will affect future electricity demand. Jordan revised its electric power tariffs in 1986 . However, a recent study showed that there still is room for using the tariff structure to increase the efficiency of electricity consumption. Nonprice demand-side activities include the possibility of significant energy savings in the transport and manufacturing sectors through appropriate conservation measures. The final area of demand uncertainty is the growth of the cconomy itself. Of particular importance here is the future growth of the industrial sector in Jordan. As discussed above, the industrial sector currently accounts for 40 percent of electricity demand in Jordan. The remainder of this section will address each of these issues in more detail.

\subsubsection{Power Interconnections and Exports}

Jordan is currently exporting a nominal amount of power to Syria after constructing tie lines to connect with Syria's grid. Power exports to Syria began in 1985 with a total of $20 \mathrm{GWh}$. In 1986 and 1987, the amount of power exported was 214 and $334 \mathrm{GWh}$, respectively. The level of these sales to Syria in the future is uncertain. However, JEA has expanded the capacity of the electrical interconnection with Syria in the recent past. And, if A plans to undertake a feasibility study with the goal of synchronizing the electrical interconnection between tie Jordanian and Syrian systems.

The Syrian 'nterconnection is the first phase of what is anticipated to be multi-country interconnections in the 199)s. Exploratory discussions on future interconnections with other ncighboring Arab countries are ongoing. In concert with other power parastatals in the Arab world, JEA formed the Arab Union of Producers, Transporters, and Distributors of Electricity. The goal of the union is to promote cooperation between Arab countries in developing generation, transmission, and distribution facilties in the Arab world. As part of this 
increased emphasis on cooperation, the union's goal is to coordinate electricity-related activities of the members, including the interconnection between national grids of the Arab countrics.

Besides the power sales to Syria, another concrete example of this cooperation involving Jordan is the feasibility study of connecting the national power grids of Jordan and Egypt. JEA and the Egyptian Electricity Authority, through a joint technical committec, conducted a prefeasibility study of interconnecting the power systems of the two countries. Based on the favorable conclusions of the prefeasibility study, Jordan and Egypt (aided by France) conducted a technical and economic feasibility study of constructing a marine power transmission line from the southern part of Jordan along the Gulf of Acjaba to Egypt. The interconnection project entered the executive stage in late August when the Ministers of Energy of both countites met in Cairo. ${ }^{6}$ A technical protocol for cooperation in energy-related matters was signed by the ministers of the two countries. Egypt and Jordan agreed to exchange expertise and information to determine the route of the marine cable linking the power systems of the two countries. They also agreed to cooperate in jointly sceking out funding sources for the project. It is expected that implementation of the link will comenence in early 1989 after additional technical studics are completed. ${ }^{7}$

The impact of constructing the marine transmission line between Jordan and Egypt on the power sales of Jordan is uncertain. Because the peak power load periods of the two countries differ (Egypt in October, Jordan in September), one possibility would be load shaving for both power grids. However, with the uncertainty associated with Egypt's power system, the effect may be a significant amount of net sales of power to Egypt from Jordan.

Another complicating factor is the possibility of an interconnected grid between Jordan, Syria, Egypt, and Saudi Arabia. As part of the altorementioned feasibility study of connecting the Jordanian and Egyptian power grids, the participants also agreed to include a study of the leasibility of connecting the power grid in Saudi Arabial. With Jordan's current transmission link with Syria, the impending link with Egypt, and the possibility of connecting with Saudi Arabia, the goal of a pan-Arab electrical connection is closer to fruition. Here again, while the purpose would be in part peak load shaving for each of the countries, the net impact on Jordanian power sales is uncertain.

Finally, there is a possibility of linking an interconnected Arab power system with the systems of Europe. Discussions among Middle Eastern Arab countries are under way on the possibility of linking Arab power grids with those of Turkey and other European countries in the early 199()s.8 Here again, the net impact of these possibilities on the Jordanian power system cannot be determined with any degrec of certainty.

\subsubsection{Demand-Side Management}

One of the ways in which JEA can meet its future load requirements is by reducing electricity consumption through demand-side measures. Demand-side management (DSM) refers to the intervention of a utility to influence its load curve. ${ }^{9}$ Broadly defined, the types of interventions include both technical and behavioral ones. Examples of technical interventions include providing efficient equipment for encrgy conscrvation and energy demand control equipment. Innovative pricing strategies and public relations campaigns for efficient energy use are examples of behavioral measures which a utility can undertake to influence encrgy consumption.

\footnotetext{
6 The Egyptian Gazelle, August 31, 1988.

7 The Egyptian Gazelle, September 2, 1988.

8 The Egyptian Cazelle, August 31, and September 1, 1988.

9 DSM activities have six generic load shape objeotives: conservation, peak clipping, valley filling, load shifting, foad growth, and flexible load shape. The objectives are not mutually exclusive. For example, a utility may desire both to elip its peak and shift load to improve load factor on the system. The objective of any individual parastatal depends on conditions in its power supply system at any given time (using excess capacity, shedding load, eliminating brownouts, and the like).
} 
The Jordanian government has undertaken both technical and behavioral measures to various degrees as part of their demand-side program. With the creation of the Ministry of Energy and Mineral Resources (MEMR) in 1984, Jordan has proceeded on an intensive program to quantify the potential role of conservation measures to rationalize energy use. Before creating MEMR, GOJ proceceded on a course to raise energy prices (both petroleum and electricity prices) to levels approaching the economic cost of supply. At present, however, there is still room for both technical and behavioral DSM programs to improve the efficiency of energy usc. Each of the measures will be discussed in detail below.

\subsubsection{Energy pricing}

Over the past decade, Jordan has moved toward correcting pricing incliciencies in both its petroleum and power subsectors. The rationalization of petroleum prices was important for the power sector because of Jordan's total reliance on petroleum for power generation. As with many developing countries, the petroleum subsector of Jordan was a net contributor to revenue generation of the government prior to the first international oil price shock in 1973 because of the amount of taxes levied on gasoline and diesel. However, the petroleum subsector was subsidized by the national government as a result of the precipitous increase in international petroleum prices in 1973; international price increases were not passed on to Jordanian petroleum users for political, economic, and social reasons. By the end of 1978, the subsidy to the petroleum subsector amounted to $\$ 66$ million. After the second oil price sheck in 1979, the government's policy changed. It concluded that, if the price increases were not passed on to consumers, the impact on the government budget would be profound. Therefore, the government decided to gradually phase out the subsidy to petroleum consumers. Since the first petroleum price increase in July 1979, there have been seven further adjustments (Fobruary 1980), February 1981, April 1981, November 1981, February 1983, December 1984, and June 1986).

Because of the recent decline in the international price of petroleum, the price of each individual petroleum product in Jordan is above its economic cost of supply. This is the case ceven though in order to promote economic competitiveness, the government decided to pass allong price decreases to certain customer classes (large industrial users and the power sector) through its tariff revision in June 1986.

Electricity prices followed a similar pattern. The average annual real increase in electricity rates was only one percent from 1975 to 1981. During that same period, JEA's fuel bill increased at an average annual real rale of 10) percent. JEA was not allowed to pass along the petroleum price increases of 1981 to consumers because of social and political considerations. A rapid increase in electricity prices was pereeived as a threat to civil order.

In the past decade there have been four tarifl changes in the power sector (March 1977, February 1980, December 1984, and June 1986). Presently, I'IA's tariff structure consists of demand rates and time of day rates for largevolume sales (bulk sales) to distribution companies and large and medium industries, increasing block rates for residential and public buildings, flat rates for commercial consumers, and a declining block rate for small industrial consumers. A fixed charge per month is levied on residential and small industrial consumers. With the tariff change in June 1986, the government reduced the prices to certain customer classes. This came in conjunction with the redustion in petroleum prices. The petroleum price decrease reduced the fised oil bill to JEA by about 21 percent.

The World Bank estimated that as of 1987 the current overall price of electricity in Jordan is 85 percent of the estimated economic cost of supply. Although this is favorable in comparison with many other developing countries, the government agreed to a marginal cost pricing study to determine the extent of the subsidy to individual sectors and, if warranted, to adjust tariff's to economic levels. Of particular concen is that electricity prices to bulk consumers, medium industry, and small industry are only 75 percent of their estimated economic 
cost of supply, based on the analysis conducted by the World Bank. The results of the marginal cost pricing study were to supposedly serve as the basis for adjusting electricity tariffs further. ${ }^{10}$

\section{3 .2 .2 Conservation}

Since its creation in 1984, MEMR has becn actively involved in promoting encrgy conservation. Several studies and programs have been initiated.

For general energy conservation activities, two conservation centers have been established to promote and technically support more efficient energy use. The centers have benefitted from the financial assistance of USAID. The first, the Encrgy and Electricity Information and Advisory Conter (EEIAC), is located in Amman and is sponsored by MEMR and JEA. The second center, located in Irbid, is sponsored by MEMR and IDECO. One of the primary functions of the conservation centers is to inform the public about energy savings by collecting and disseminating information about energy conservation. Activities include holding seminars, advertising, and preparing and distributing publications on energy conservation. As second major activity of the centers is conducting cnergy audits and providing technicall advice based on on-site inspections. The advice has encompassed using thermal insulation, designing passive-solar-heated buildings, nstalling solar water heaters, and using electrical equipment more cefficiently.

Besides the conservation centers, MEMR is engaged in sector-specifie activities. In the residential sector, the most important activity is promoting the use of solar water heaters. Presently, 25 pereent of houses use olar water heaters in comparison to less than 5 percent before 1980). In addition to promoting the use of solar heaters, the MEMR is engaged in establishing standards (design specifications) for the technical quality of solar heaters to improve their performance. Related $t$ this is a program to enhane the technical know-how of workers engaged in the manufacture of solar water healers. Another major conservation activity in the residential sector is related to windows. A study was conducted to determine the optimal design of windows to prevent air infiltration.

In the industrial sector, MEMR contracted with the Bechtel Group, Ince for a study of potential energy savings through conservation measures in large industries. 'The study, conducted in conjunction with Technical Audit, Ltd. of England, was carried out in 1985.11 A three-step proeedure was used to idcontify individual industrial plants for intense scrutiny, resulting in detailed audits of 14 industrial plants. Included in the plants chosen for detailed audits were the oil relinery, cement plants, phosphate mines, and a fertilizer plant, which accounted for nearly 6) percent of the tolal amount of electricity used in the industrial sector in 1987 . Electricity use by major industrial users will be discussed in detail in the next section.

The results showed that 80 percent of the total potential energy savings from the 14 audited plants comes from petroleum refining, the fertilizer plant, and piwsphate mining. For electricity consumption, the estimated savings for phosphate mining was approximately 10 perent of total 1985 consumption in the mines.

In the transport sector, an energy conservation study was conducted for the five largest transport companies-Jordan Syrian Land Transport Co., Jordan Iraqi Land Transport Co., Public Transport Corporation, Royal

\footnotetext{
10 The marginal cost pricing study onlitled "Long Run Marginal Cost Analysis and lilectricity P'ricing" was completed by Meta Systems and Ihagler-Bailly in March, 1988. The study made a number of recommendations for changing the level and structure of electricity prices in Jordan. However, by the authors' own admission, line study did not include the impact on net reventues of changing electricity tariffs for both Jis and Jordan's other electric utilities (the preceding chapter discusses the power system in Jordan). This proved to be one of the primary problems of the study. Although the results of the stl. 'y were generally perceived as reflecting a "theoretically correct" rate structure, the decision to propose it to higher manngement was postponed because it did not present tho impact of the structure on revenues. JliA is especially mindful of its self-financing covenant with the World Bank, which targets an annual self-financing ratio for the Jordanian electric system of 25 percent of all capital expenditures.

11 Overseas Bechtel, Inc, and 'l'echnical Audit, Led, Energy Conservation Study in Jordan, 1985.
} 
Jordanian, and JPRC. The results show that conservation measures could save between 7 to 15 percent of total cnergy consumption; valued at 4.5 million JD per annum. An economic fassibility study for establishing a center for training drivers in energy efficiency was also conducted. The center would be set up in cooperation wh the the vocational training corporation.

\subsubsection{Econemic Growth}

'Table 3.6 provides the growth rales for Gross Domestic Product (GDP) and Gross National Product (GNP) for' sclected periods from 1975 to 1987. From 1975-1980 cconomic growth in the Jordan economy was more than 14 percent annually as measured by both GDP and GNP. In the carly 1980s, growth slowed considerably, falling as low as 2.4 percent per annum in 1987. The rapid increase in total cconomic growth during the 19751980 period explains in large measure the prolific growth in electricity demand during that period $(26.3$ percent per annum from 1975-1980 from Table 3.2),

Table 3.6 Average annual growth in GDP and GNP, 1975-1987 (percent)

\begin{tabular}{ccc}
\hline Period & GDP & GNP \\
\hline $1975-80$ & 14.7 & 14.1 \\
$1980-85$ & 5.0 & 3.7 \\
$1985-86$ & 2.6 & 3.9 \\
$1986-87$ & $\mathrm{NA}$ & 2.4 \\
\hline
\end{tabular}

Source: Central Bank of Jordan, Monthly Slatistical Bulletin, January 1988

The primary reason for the difference in grow th rates between GDP and GNP is the amount of remitlances to the Jordantan economy. Table 3.7 provides an analysis of the historical importance of remitlances 12 to the Jordanian economy from 1976 through 1986. In Table 3.7, Gross National Product is comprised of Gross Domestic Product and net factor income. The latter is composed of foreign remittances and net investment income carned abroad.

Table 3.7 Analysis of gross national product, selected years, $1976-1986$ (millions of current Ji)

\begin{tabular}{lrrrrrr}
\hline & 1976 & 1980 & 1981 & 1984 & 198.5 & 1986 \\
\hline Gross Domestic Product & 421.6 & 984.3 & 1164.2 & 1499.4 & 1573.3 & 1613.6 \\
Factor Income - Not: & & & & & & \\
Remittances - Nct & 131.3 & 190.7 & 288.9 & 377.5 & 310.0 & 366.0 \\
Investment Income & 9.5 & 15.1 & 29.6 & -22.4 & -34.1 & -62.2 \\
& & & & & & \\
\hline Gross National Product & 562.4 & 1190.1 & 1482.7 & 1854.5 & 1849.2 & 1917.4 \\
\hline & & & & & & \\
Remittances - \% of GDP & 31.1 & 19.4 & 24.8 & 25.2 & 19.7 & 22.7 \\
Remittances - \% of GNP & 2.3 .3 & 16.0 & 19.5 & 20.4 & 16.8 & 19.1 \\
\hline
\end{tabular}

Source: Central Bank of Jordan, Monthly Statistical Bulletin, January 1988

12 Remittances are factor (labor) income eamed by Jordanians working abroad and sent back to Jordan. 
The table illustrates the large slate of GNP accounted for by remittances to the Jordanian cconomy, In 1976, remittances accounted for nearly one-guarter of GNP. However, the percentige is substantially lower in recent years. These remittances have been historically important in explaining the large rate of growth in electricity demand over the past decade. However, the future amount of these remiltances to the Jordanian economy is uncertain. It is contingent on events in the international economy which are largely beyond the control of the Jordanian govermment. The majorily of remittances have historically been derived from Jordanians working in the Middle East. The infusion of "petrodollars" associated with the large increases in petroleum revenues of Middle East oil-exporting countries during the 197()s led to large-scale construction projects, inducing Jordanian workers to seck employment in the oil-exporting countries. The level of these remittanees in the future is tied to the international price of petroleum. With the recent decline in intemational crude sil prices, many construction projects have been cancelled in the Middle East, leading to a decline of forcign remittances to the Jordanian economy.

The amount of remiltances is only on: uncertain factor in estimating future growth in the Jordanian economy. Both domestic and international conditions will impinge on that growth. Meta Systems et al, simulated the performance of the economy over the 1986-20(0) period under different assumptions about both domestic and international economic conditions, using a general ecpuilibrium model of Jordan's economy. A base casce scenario was executed along with 11 other sensitivity studies. The base case seenario reffected "reasonable" assumptions about the international economy, energy supply conditions, and economic policy until the year 20(0). International petroleum prices were assumed to increase gradually, while domestic energy prices were assumed to adjust instantly in the base case scenario. Forecasted growth in GDP under this scenario is 3.4 perent annually over the 1986-199() period and 5.2 percent per annum from :99()-2(0)(). Average annual growth of GDP over the entire period was simulated to be 4.7 pereent. This rate approaches the actual growth of GDP from 1980-1985, but is significantly above the most recent growth in the 1985-1987 period (see Table 3.6).

The other 11 secenarios bracket the base calse, ranging from an average annual grow th of 4.1 pereent over the 1986-200() period on the low end and 5.6 percent using the most optimistic set of exogenous assumptions. On the low end, the forecasted annual growth rate of 4.1 pereent is less than what was experienced by the Jordanian conomy from 198()-1985, but significantly higher than the 1986 growth rate (Table 3.6). On the high end, the forecasted growth is larger than that experienced over the 198()-1985 period. The 4.1 percent growth rate was derived from the same macroeconomic assumptions as used in the base case, but, in contrast to the base case, international oil prices were assumed to rise rapidly in the forecast horizon and domestic energy prices were assumed to be constant. The scenario with the most optimistic forecasted growth of 5.6 percent annually included very favorable exogenous macrocconomic assimptions with a gradual rise in international petroieum prices and domestic encrgy prices adjusting to the increases.

An important consideration in assessing the future growth of the Jordanian economy and, hence, future electricity requirements, is growth prospects for the major industrial users of electricity. Table 3.8 presents tolal industrablecetricity consumption and the pereentage composition of large users of ele.tricity in the industrial sector by industry and the total amount and perentage composition of electricity used by small and medium industries for selected years from 1977 through 1987.

The last entry in the table reproduces the information contained in Table 3.1, indicating the percentage of total electricity sales accounted for by sales to industrial consumers. The table shows that industrial users of electricity in recent years accounted for 40 pereent of total electricity consumption. The share of total industrial electricity consumption accounted for by large-volume users increased from 59.4 percent in 1977 to 75.6 percent in 1987. The increase is due in large part to the introduction of potash mining and fertilizer production since 1980. The production of cement has historically accounted for a large portion of industrial electricii, sales. In 1977, more than one-third of total industrial clectricity use was accounted for by cement production, declining to a third in 1980, and, most recently, falling to 26.() pereent of total industrial consumption in 1987 . The use of clectricity by small and medium industries as a percentage of total industrial electricity consumption declined 
from 40.6 percent in 1977 to 24.4 percent in 1987, reflecting in large measure the introduction of potash mining and fertilizer production in the Jordanian econony since 1980.

Table 3.8 Industrial electricity consumption, amount and percentage composition by source, selected years, 1977.1987

\begin{tabular}{|c|c|c|c|c|c|c|c|c|}
\hline \multirow[b]{2}{*}{ Source } & \multicolumn{2}{|c|}{1977} & \multicolumn{2}{|c|}{1980} & \multicolumn{2}{|c|}{1985} & \multicolumn{2}{|c|}{1987} \\
\hline & GWh & $\%$ & GWh & $\%$ & GWh & $\%$ & GWh & $\%$ \\
\hline Oil Refining & 20 & 20 & 26 & 8.5 & 66 & 7.3 & 68 & 6.4 \\
\hline Cement & 6.3 & 63 & 102 & 33.3 & 253 & $28 .()$ & 276 & 26.0 \\
\hline Potash & () & () & () & $(0.0$ & 153 & 16.9 & 188 & 17.7 \\
\hline Phosphate & 21 & 21 & 47 & 15.4 & 81 & 9.0 & 99 & 9.3 \\
\hline Fertilizer & () & () & () & $(0,0$ & 136 & 15.1 & 147 & 13.9 \\
\hline Total & & & & & & & & \\
\hline Large & 104 & 59.4 & 175 & 57.2 & 689 & 76.3 & $8(22$ & 75.6 \\
\hline Small/ & 71 & $4(0.6$ & 131 & 42.8 & 214 & 23.7 & 259 & 24.4 \\
\hline Total Industry & 175 & 100.0 & 306 & 100.0 & 903 & 100.0 & 1061 & 100.0 \\
\hline $\begin{array}{l}\text { Industry } \\
\text { (\% of total) }\end{array}$ & & 34.1 & & 34.9 & & 42.0 & & 39.9 \\
\hline
\end{tabular}

Prospects for future growth in the industrial sector are uncertain. Initially, we examine output by the major industrial users over the past decade and then look at future prospects. Table 3.9 quantifies the recent activity of major industrial electricily users, presenting their output for selected years from 1977 through 1987. The output of ecment increased at an average annual rate of 14.8 percent between 1977 and 1987 . However, in recent years the grow th has not been favorable. Although production increased by nearly 28 percent in 1987, it declined by 12.0 percent in 1986 and, although not contained in Table 3.9, declined by 0.2 percent in 1985. Future prospects are uncertain. Middle East markets for cement have diminished considerably with the reversal of the "petrodollar" construction boom in the area. Other international markets will have to be tapped if petroleum prices continue at their depressed level.

Table 3.9 Output of major Jordanian electricity users, selected years, 1977-1987 (thousand tonnes)

\begin{tabular}{crrcc}
\hline Yair & Cement & Potash & Phosphates & Fertilizer \\
\hline 1977 & 538 & 0 & 1769 & 0 \\
1980 & 913 & 0 & 3911 & 0 \\
1985 & 2023 & 908 & 6067 & 510 \\
1986 & 1795 & $11(12$ & 6249 & 551 \\
1987 & 2372 & 1203 & 6845 & 604 \\
\hline
\end{tabular}

Source: Central Bank of Jordan, Monthly Statistical Bulletin, January 1988. 
The second major industrial user of electricity in Jordan, potash mining, faces a similar uncertain future. Potash production increased by 19.3 percent in 1986 and 8.8 percent in 1987. Jordan increased its potash exports in 1986, a year in which the international potash industry was depressed. The increase was attributable to increased exports to East Asia (primarily China), Brazil, and India. However, the increase to these regions was partially offset by the loss of some markets in East and South Asia to Canada. Even though the total volume of potash sales increased in 1986, the average price per tonne decreased, leading to a decline in total revenues. The future for the potash industry is clouded, but it is conceivable that Jordan could lose more of its Asian markets to Canada and, possibly, to Isracl.

Phosphate production increased at an average annual tate of 13.5 pereent over the 1977-1987 period. Most recently, production has slowed over the historically high levels, growing by 3 percent in 1986 and 9 pereent in 1987. The Jordan Phosphate Mining Company (JPMC) has two markets for its output. The first is its newly acquired diammonium phosphate fertilizer division. Sales to this division have been increasing in recent years. Production for export markets is the second use of JPMC's phosphate production, accounting for more than fivesixths of JPMC's sales. Most recently, Jordan has increased its market share for phosphate exports. Its principal markets are in Eastern Europe, East Asia, and South Asia. Jordan has recently increased its exports to Eastern Europe by extending more generous credit terms to Yugoslavia and Poland. It has also altempted to gain new markets (Western Europe, Canada, and Mexico) by expanding into areas previously dominated by Moroceo and the United States. The expansion of exports is not costless. Nearly onc-third of Jordan's phosphate exports go to Romania, Poland, and Yugoslavia in Eastern Europe. Since each of these countrics hats forcign exchange shortages, Jordan must accept inferior goods as partiai payment for its exports. Also, by infringing on markets formerly dominated by Moroeco, JPMC has seen relaliation by Moroceo in its luerative South and East Asian markets.

JPMC commeneed operations of its diammonium phosphate ir rilizer plant in 1982, Every year since it began producing fertilizer, it has operated at a loss. Since beginning production, it has had to periodically shut down because of surplus inventories with inadequate storage capacity. Most recently, JPMC has changed its business strategy for fertilizer production and exports. It has decided to operate the plant at near capacity and conduct a bold marketing effort to increase exports, hoping to rediec the average fixed cost per unit of fertilizer sales and thereby reduce its losses. In the process, it has diversilied its geographical source of exports, emphasizing Western European mar'iets at the expense of ones in South A sia. Although the largest individual market for cxports is India, the largest regional market is now Western Europe (more than a third of total exports), displacing South Asia as the most important regional market. Also as a part of its new business and marketing strategy, JPMC is nergotiating bilateral trade and counterpurchase agreements to obtain cheaper sulfur and ammoria which are important inputs in the production of diammonium phosphate fertilizer.

The future growth of the Jordanian economy and, henee, electricity demand growth depends in large measure on both the performance of the cement, potash, phosphate, and fertilizer industries and the ability of Jordan to develop new export industries. With respect to the laller, a key problem is that the Jordanian economy is relatively small and unable to absorb the output of many manufacturing industries. To achieve the cconomies of scale required to be competitive in many of these industrics, export markets must be developed. Jordin has a number of advantages to accomplish this. One of the most important advantages is that it is geographically close to the lucrative Middle Eastern markets with which the Jordanians shatre similar ethnic and cultural backgrounds. Another important advantage is that Jordan has a relatively good infrastructure with a fairly well developed transport network and reliable electricity and telephone service. Still, given these advankages, it remains uncertain whether Jordan can develop and maintain economically viable export industries to sustain strong economic growth. In a recent study, the Workd Bank examined the prospects for small-and medium-scale enterprises for Jordan over the short- and long-run time frames. ${ }^{13}$ The study concluded that prospects in the

13 World Bank, Jordan: Policies and Prospects for Simall and Medium Scale Manufacturing Industries, January 1988, No. 6848-J0. 
short run are not favorable. However, over the longer run small and medium industries could contribute significantly to economic growth if a series of reforms to promote growth are undertaken in the economy. The suggestions include reform of trade laws and the investment licensing system and a number of institutional improvements in the economy.

\subsection{ASSESSMENT OF THE NEED FOR POWER}

The power sector in Jordan has grown very rapidly over the past two decades, especially in the late 1970)s and early 1980s when an cionomic boom saw electricily demand growth rates exceeding 20 percent per annum. However, growth has recently slowed and, based on demand projections by Meta Systems et al., will not excecd 5 percent per annum the rest of this century. These projections are based, however, on a well-defined set of assumptions about the future course of economic events which may or may not transpire. Demand-side management, including both electricity pricing and conservation measures, will rationalize the use of electricity in the future. The future price of oil is indeterminate, and its effect on the grow th of the Jordanian economy and electricity demand - has been and will be significant. The export markets and growth potential for major domestic industrial users of electricity are uncertain. International prices of crude oil will be a significant factor for the future growth of the cement industry in Jordan. Perhaps even more significant for electricity growth is the potential effect that electricity interconnections between Jordan and other Arab countries (especially Syria, Egypt, and Saudi Arabia) will have on the Jordanian power system. These interconnections could potentially affect Jordan in several ways. They could conceivably be a future source of demand, requiring capacity growth, or they rould contribute to load shedding on the Jordanian system in the 1990)s and beyond, improving Jordan's load factor with a concomitant decrease in capacity requirements to meet peak load.

Although all utility systems face ancertainties, the ones confronting Jordan on the demand side are especially acute. On one hand, failure to anticipate growth in electricity demand can stifle overall economic growth in the economy; nn the other, building excess power production capacity carries with it a high economic opportunity cost in terms of other investment altematives which may be taken by the economy in place of power generating facilities.

Given these demand uncertainties, evaluating the need for power in Jordan is an extremely delicate problem. The uncertainties with circumstances that may impinge on electricity demand growth in the future strongly suggest that there is no "best" forecast of load growth over the next twenty years. At one extreme, however, it is fairly certain that historical electricity growth rates will not be equalled or exceeded in Jordan for any lengthy period in the future. The 26.3 percent and 17.9 percent average annual growth rates in electricity consumption over the 1975-1980 and 1980-1985 time periods occurred during periods in which domestic and international economic conditions were amenable to load growth in Jordan. At the other extreme, the growth in electricity demand is difficult to call.

Given these uncertainties, we choose here to bound the problem of determining load growth by using JEA's 1987 forecast of peak load to provide an indication of the range of capacity regurements that may be needed on the Jordan power system over the next two decades. ${ }^{14}$ As discussed carlier, JEA produces an annual forecast of electricity demand and peak load growth under three scenarios (low, medium, and high) that reflect a range of assumptions about future domestic and international conditions which may influence electricity demand. Table 3.10 presents JEA's forecasted peak loads fur the interconnected power system (excluding exports of power to Syria) under the three scenarios for five-year iicrements beginning in 1986 and extending to 20(05, along with an analysis of required capaci'y additions over that period.

14 The Meta Systems et al. study of energy demand did not produce ferecasts of peak Inad. 
For the sake of clarity of presentation, the implied annual average growth rates for the levels of forecasted peak load over the 1986-2005 time period are not included in the table. They are 4.5 percent, 6.0 percent, and 7.4 percent for the low, mid, and high scenarios, respectively. Each of the forecasted growth rates in peak load is significantly below the experiences of the last decade (Table 3.3 above). Most recently, peak load has grown at an annual average rate of 11.1 percent from 1985-1987. The associated annual average growth rates in electricity demand for the low, mid, and high scenarios are 4.7 percent, 6.3 percent, and 7.6 percent, respectively. The low growth scenario with a forecasted annual growth in electricity demand of 4.7 percent most closely corresponds to the growth rates produced in the Meta Systems et al. study.

The required capacity figures in Table 3.10 are simply 30 percent larger than the peak load forecasts, corresponding to the 30 pereent reserve margin used by JEA in its planning. 15 The existing capacity is simply the amount that existed on Jordan's interconnected system in 1986, less JEA's planned retirements. It is the basis from which capacity planning berins. The incremental capacity provided in the last category of information in Table 3.1() is simply the amount of required capacity less capacity existing in 1986. It is the estimated amount of additional generating capacity needed to be constructed in the various time frames.

The results in Table 3.10 indicate that, under the high growth scenario, Jordan will need $60 \mathrm{MW}$ of additional capacity by 1990 ). In addition, another $485 \mathrm{MW}, 472 \mathrm{MW}$, and $546 \mathrm{MW}$ will be needed by the years 1995 , $20(0)$, and 2005 , respectively, totalling $1,546 \mathrm{MW}$ of total additional capacity by the year 2005. At the other extreme, Table 3.10) shows that no additional capacity will be needed by 1990 under the low growth scenario and, over the 20-year period, only $543 \mathrm{MW}$ will be needed in total. With total capacity requirements under the mid grow th scenario estimated to be $1,001 \mathrm{MW}$, there is a significant variation in generating requirements with nearly a three-fold difference between the low and high estimates. Satisfying this capacity requirement is the subject of the next chapter.

Table 3.10 Jordan power system, forecasted peak load, required capacity, and new capacity, thirty percent reserve margin, 1986-2005 (MW)

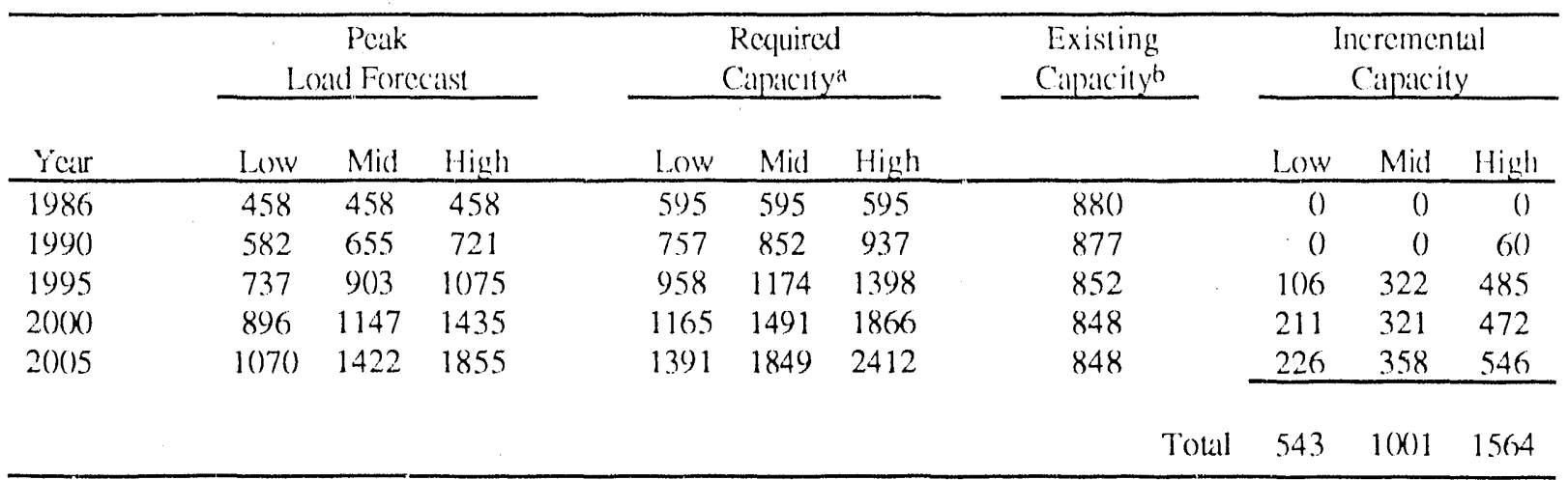

\footnotetext{
a Assumes reser e margin of 30 percent for all periods

${ }^{b}$ Capacity existing in 1987 less scheduled retirements through 1997. Retirements beyond 1997 are unknown.
}

\footnotetext{
15 Note that a 30 percent reserve margin to meet peak load does not necessarily imply a 70 percent capacity factor. The relationship between the two depends on the load factor of the system.
} 


\section{ACCOMMODATING FUTURE CAPACITY REQUIREMENTS}

\subsection{THE JORDANIAN POWER SYSTEM}

The national power system in Jordan is thermally dominated, using primarily heavy fuel oil and, to a lesser extent, diesel as primary fuels. ${ }^{1}$ At the end of 1987 , there was 979 MW of installed capacity in Jordan. Of this total, $869 \mathrm{MW}$ was owned by the Jordan Electricity Authority (JEA) and the remainder by private companies, municipalities, and other power distribution companies in Jordan. ${ }^{2}$ An additional $21 \mathrm{MW}$ of capacity is connected to JEA's system, bringing the total capacity of the interconnected system to $890 \mathrm{MW}$ at the end of 1987.

Figure 4.1 characterizes the interconnected power system in Jordan. ${ }^{3}$ It consists of the main power generating stations and a theorctically plausible 4())-kV transinission line from Acaba on Jordan's southern coast to the Amman South station near the capital city, Amman. At present, the 4())-kV line operates at $132 \mathrm{kV}$. JEA placed a tender for upgrading the line $10400 \mathrm{kV}$, but the $132 / 4(0)-\mathrm{kV}$ substations were postponed because of the delay in construction of the $2 \times 13(0)$-MW units at Augaba. ${ }^{4}$ In addition to the main north-south transmission link from Amman South to Aqaba, the grid extends up to Irbid in the North with a 132-kV tie line. From Irbid, two tic lines (one a 66-kV line, the other $230 \mathrm{kV}$ ) connect Jordan's national grid with that of Syria's. Besides these north-south ties, Figure 4.1 shows that two 132-kV tic lines are presently under construction. The first in the northern part of the country will connect the Amman South station with Risha in the East. The latter is the site of the natural gas discovery in Jordan. 5 In addition to transmitting power produced at the well-sites to the main consumption centers in Jordan, it will serve to electrify some remote areas along its route. The line is expected to be completed at the end of 1988 or early 1989 to transmit power from the $2 \times 3$ ()-MW gas turbines at Risha. The second 132-kV transmission line under construction links Ma'an with Shidiya in the southeastern part of the country. Shidiya is the site of the new phosphate mine in Jordan. The line is expected to be completed in late 1988 or carly 1989.

Figure 4.1 shows the main thermal power generation sites at Agaba in the southern-most part of the country; Zarya (the Hussein Thermal Power Station) which is $35 \mathrm{~km}$ north of Amman; Marka, just north of Amman; Amman (South); and Karak, which is east of the southern part of the Dead Sca. ${ }^{6}$ Table 4.1 provides JEA's capacity at each of the five generating sites by prime mover.

\footnotetext{
1 There is a nominal amount of hydroclectric power generation with $7 \mathrm{MW}$ of capacity at the end of 1987 . Renewable energy plays a minor role in the powe system. Its role will be discussed below.

2 A thorough discussion of the relationship of JEA to the two other power distribution companies (the Irbid District Electric Company and the Jordan Eilectric Power Company) and private power producers is presented in Chapter 2.

3 For clarity of presentation in the figure, we include only JI:A's steam, gas turbine, and diesel power generating stations and two private generators which are pan of the interconnected grid. The hydroelectric capacity is not included. The capasity of other power generators was presented in Table 2.2 of Chapter 2.

4 'The two units at Aqaba were to be the second stage of capacily expansion at the Aqaba port. The first stage was completed in 1986. The reasons for its delay will be discussed below.

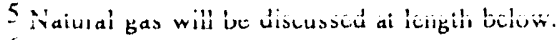

6 Excluded from the discussion are the two hydroelectric sites: one at the King Talal Dam, the other at Agaba.
} 


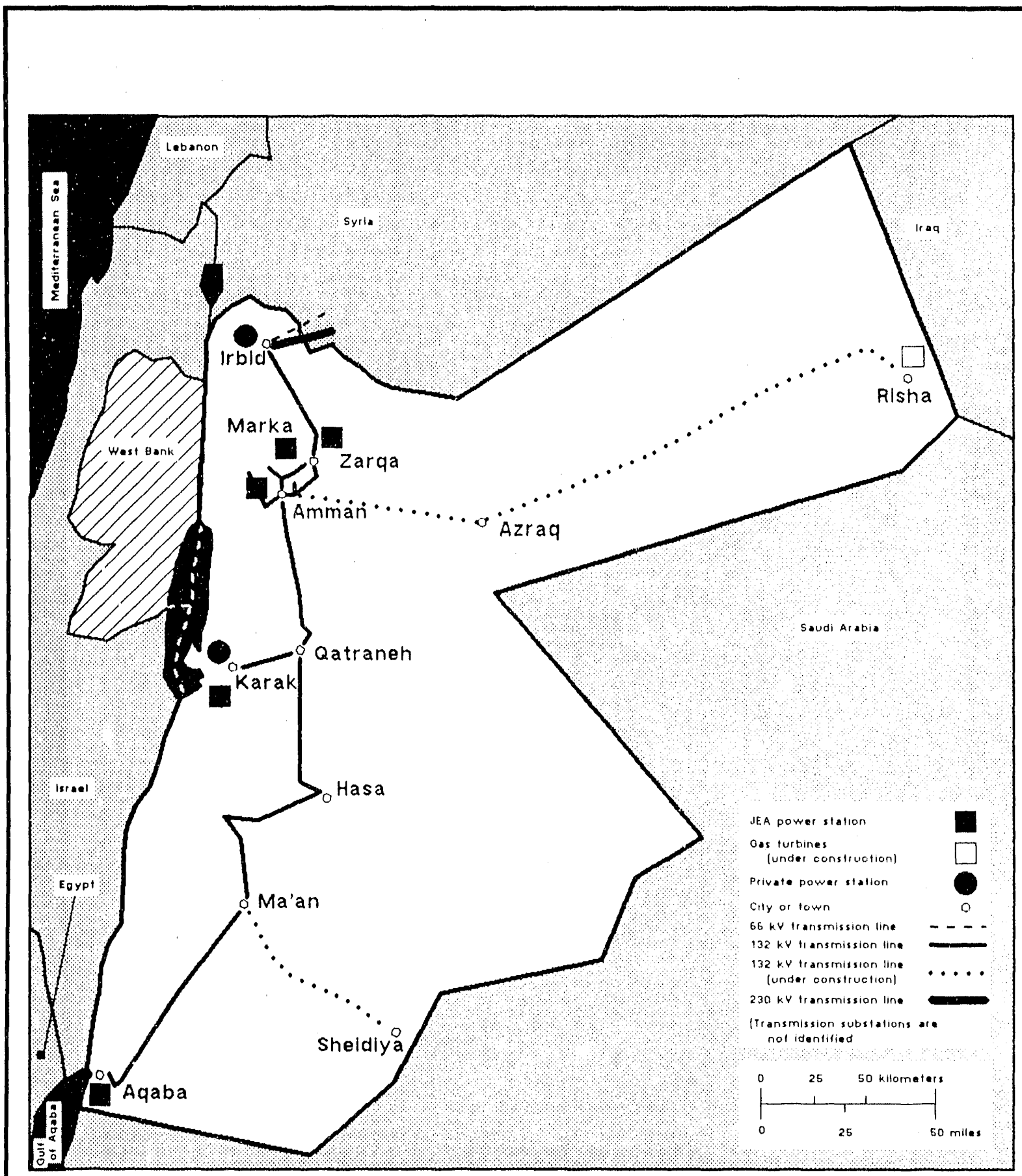

Figure 4.1 The interconnected power system in Jordan 
Table 4.1 Power Generating Stations, Jordan Electricity Authority, By Capacity and Prime Mover, December 31, 1987 (MW)

\begin{tabular}{|c|c|c|c|c|}
\hline Site & Stcam & Gas & Diescl & Totala \\
\hline Acpaba & $2 \times 130$ & & $\begin{array}{c}2 \times 3.5 \\
3 \times 5\end{array}$ & 282 \\
\hline Zarqab & $\begin{array}{l}3 \times 33 \\
4 \times 66\end{array}$ & $\begin{array}{l}1 \times 14 \\
1 \times 18\end{array}$ & & 395 \\
\hline $\begin{array}{l}\text { Marka } \\
\text { Karak } \\
\text { Amman } \\
\text { South }\end{array}$ & & $\begin{array}{l}4 \times 18 \\
1 \times 18 \\
2 \times 30\end{array}$ & $\begin{array}{c}30 \\
3 \times 1.5\end{array}$ & $\begin{array}{c}102 \\
23 \\
60\end{array}$ \\
\hline Total & 623 & 182 & 57 & 862 \\
\hline
\end{tabular}

The $623 \mathrm{MW}$ of steam generating capacity, using heavy fucl oil, represents the most cconomic units on the system. In terms of a theoretical loading order based on the economics of the units, the $2 \times 13()$-MW units at Acjaba and the $4 \times 66-\mathrm{MW}$ units at Zarqa rank first and second. The $182 \mathrm{MW}$ of gas turbines used diesel oil as their primary fuel in 1987. The $57 \mathrm{MW}$ of diesel units used oil fucl as their primary fuel in 1987 . The two oldest units on the system are the two gas turbines at HTPS, coming on line in 1975 and 1976. The newest units on the system are the $2 \times 130-\mathrm{MW}$ steam units at Agaba.

Table 4.2 provides operating results for Jordan Electricity Authority's (JEA'S) power system for eleven months (January 1 through November 30) in 1987. In comparison with typical utility reporting in the United States, the data contained in Table 4.2 are homologous to the operating expenses of a utility. The capacity data listed in the table correspond in the aggregate to the amounts listed in Table 4.1 by type of prime mover. 'Thus, not only is the total capacity factor for JEA's entire system a weighted average across different units, but capacity factors for individual generating stations are weighted averages to varying degrees. 


\section{Table 4.2 Operating Results for Generating Stations, Jordan Electricity Authority, Eleven Months, January-November, 1987}

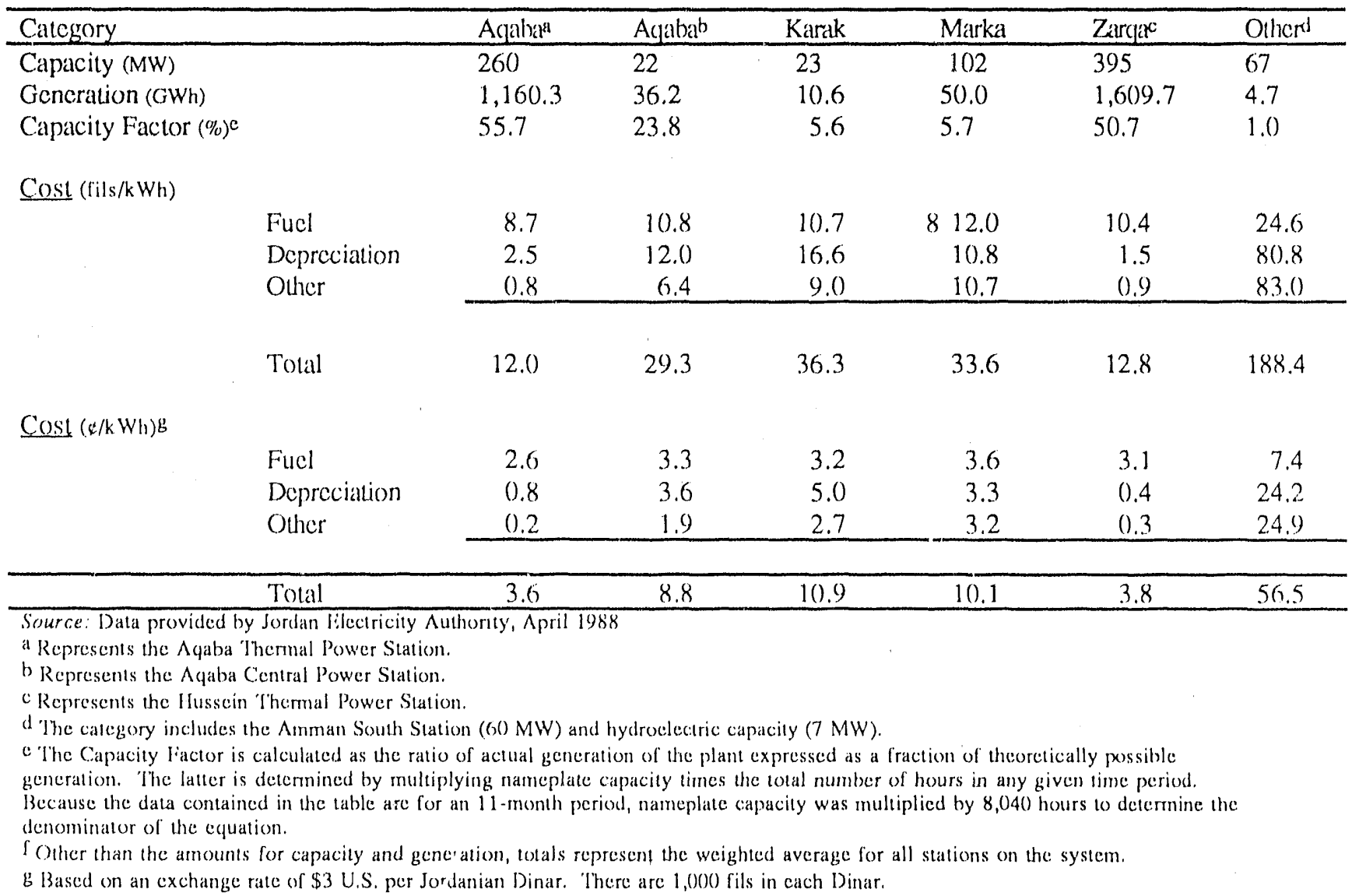

The most extreme example of this is the data listed for Zarqa (the Hussein Thermal Power Station). Here, as Table 4.1 shows, the $395 \mathrm{MW}$ of capacity listed in Table 4.2 is divided between $3 \times 33-$ and $4 \times 66-\mathrm{MW}$ steam units and $1 \times 14$ - and $1 \times 18$-MW gas turbine units. Thus, the capacity lactor of 50.7 pereent shown for Zarya in Table 4.2 is a weighted average of each of the individual units.?

The table shows that the $2 \times 130-\mathrm{MW}$ units at Acaba, using heavy fucl oil, and the $39.5 \mathrm{MW}$ of capacity at Zarqa had the highest capacity factor for the 11 -month period at 55.7 percent and 50.7 parcent, respectively. As mentioned above, the $2 \times 13()-\mathrm{MW}$ units at Aqaba and the $4 \times 66-\mathrm{MW}$ steam units at Zarqa (264 MW out of a total of 395) are ranked one and two in the economic loading order of the system. In total, the $869 \mathrm{MW}$ of capacity on JEA's system had a weighted average capacity lactor of only 41.2 percent. Several comments are in order. First, the peak load on JEA's system - including exports to Syria - was $563 \mathrm{MW}$ in 1987.8 JEA's total

\footnotetext{
7 This problem cannot be avoided because the data presented in Table 4.2 are at the finest level of detail available to the study tcam.

8 Note here that the peak of $563 \mathrm{MW}$ does not correspond to the data presented in Table 3.3 of the previous chapter. The peak load licted there was $593 \mathrm{MW}$. Here, we are addressing only JLA's system - not the remainder of the interconnected system and private power generators.
} 
capacity is $869 \mathrm{MW}$, indicating a substantial rescrve margin to provide peaking power. The most plausible explanation as to why the system operates at such a low capacity is that the peak on JEA's system occurs in September and its load factor is substantially below unity. Second, the data in Table 4.2 do not say anything about availability of units. In its planning, JEA schedules 35 dalys of maintenance for the $2 \times 130$ units at Aquaba and 29 days for the $4 \times 66-\mathrm{MW}$ at Zarcal, the fïrst two stations in the economic loading order. From the data provided to the study team, it is not possible to tell, however, the duration of forced and unforced outages on any part of the system.

Table 4.2 shows that the operating cost per kWh of generated electricity for the entire system over the 11 -month period was 13.4 fils $/ \mathrm{kWh}(1,0)($ ) fils equals a Jordan Dinar). Using an exchange rate of $\$ 3$ U.S./JD, the average operating cost on the entire system was $4.0 \% / \mathrm{kWh}$. Becaluse of their positions in the cconomic loading order and their consequent capacity factors, the $2 \times 130$ - MW units an Ayaba and those at the Zarqa power station (HTPS) had the lowest unit operating cost of any of the stations on the system, totalling $3.64 / \mathrm{kWh}$ and $3.84 / \mathrm{kWh}$, respectively, which are both less than the average total system operating cost of $4.04 / \mathrm{kWh}$.

\subsection{CURRENT SYSTEM PLANNING}

As part of the long-range planning prexess, JEA conducted a least-cost power generation expansion study in 1984. The generating alternatives which were considered in the study included gas turbines, combined cycle units, and thermal stations using coal, oil, or a combination of the two. The results of the study showed that, under both forecasts of fuel prices at the time and estimates of capital costs, the least-cost solution to JEA's capacity requirements was two 130-MW steam units to be located at the site of the $2 \times 130$ )-MW steam units which were under construction at Agaba (the Aqaba Thermal Power Station) at the time and eventually came on line in 1986. The two additional units were anticipated to be on-line in 1991-92. These units were to be dualfired: coal would be the primary fuel and oil the backup.

Following the 1984 study, other studies continued to show that the additional $2 \times 13$ )-MW units at Agaba would be sufficient to meet the power needs of the country. Therefore, the units were sent out for bid in 1987. Based on eonditions existing at the time and a forecast of the relative costs of petroleum and coal, a decision was made to use coal as the primary fuel in the two units to minimize operating expenses. However, considering the up-front capital costs for coal handling and storage, the original decision was reversed; heavy fucl oil would initially be used for the additional $2 \times 13()$-MW units designated Agabal II to distinguish them from the $2 \times 130$ )MW oil-fired units coming on line in 1986.

During this planning process, natural gas was discovered at Risha in the northeastern part of the country (sce Figure 4.1 above). Although the extent of the gas reserves is unknown, ${ }^{9}$ a decision was made in the middle of 1987 to construct $2 \times 30$-MW baseload gas turbines at Risha because it was believed that the reserves were sufficient to supply at least these units. The on-line date for the two units is expected to be late 1988 or carly 1989. In JEA's loading order, the two units would be first in the economic loading order. With the decision to build 6 ) MW of capacity at Risha and the prospect of finding additional quantities of natural gas, JEA further delayed construction of the two additional units at Ayaba. The first unit at Ayaba II is delayed to the middle of 1992 and the second unit delayed until the end of 1992.10

A 132-kV transmission line from Risha to Amman South is currently under construction to transmit the power from the gas-fired units at Risha (see Figure 4.1 above). The capacity of the line can accommodate the 60) MW of power currently under construction at Risha and $20 \mathrm{MW}$ of additional capacity. If natural gas reserves prove to be sufficient, the $2 \times 30$-MW of capacity at Risha can be supplemented by another $4 \times 30$-MW in the future.

\footnotetext{
9 Natural gas will be discussed in greater detail in the next section.

10) The tone of conversations with staff members at Jlı suggested that the delays may extend well beyond these "official" dates.
} 
Based on the most pessimistic projection of eapacity requirements discussed in the previous chapter (543 MW of additional capacity by 2005 , using a 30 percent reserve margin to meet the projected peak load of the system), Jordan cannot meet its power generation needs until 20)5 by constructing the $6 \times 30$-MW gas-fired units at Risha and the heretofore "shelved" $2 \times 130$ dual-fired units at Açaba II. This scenario is further complicated by a number of factors on both the demand and supply sides.

First, as the previous chapter pointed out, there are a number of complicating factors in the load projections for the Jordanian power system, including the imminent power interconnection with Egypt and potential power interconnections with other neighboring Arab countries and Eastern Europe; demand-side management activities, which at the very least could result in clipping the peak of power demand; and the uncerlain future growth of the Jordanian cconomy which is affected by the future price of petroleum and the ability of large-volume, industrial electricity users to further exploit international markets for their output. Each of these factors hats a potentially significant influence on future capacity requirements of the Jordanian power system. As the previous chapter pointed out, there is a wide range of projected calpacity recpurements.

Second, in planning for capacity requirements into the next century, consideration must be given to the age and composition of the current power system. The oldest unit on JEA's system is a 14-MW gas turbine at Zarga, which came on line in 1975. The newest are the two 130-MW thermal units at Ayaba which canne on line in 1986. The majority of other units have commercial operating dates in the late 1970) and early 1980)s. In the long-range planning context of this study, it might well be that some of these units will be retired within the planning horizon of this study.

Third, the $2 \times 130$ )-MW thermal units delayed at Acaba (using heavy fucl oil and/or coal) may prove to be less economic than other generating options available to Jordan, including plants constructed to use indigenous energy resources. The two units al Agaba, whether using coal or oil, require significant amounts of forcign exchange because the fued inputs must be imported. And, depending on the extent of indigenous energy resources, it may prove economically feasible to replace ollher existing boilers which are presently not scheduled for retirement.

The remainder of this chapter looks at Jordan's indigenous energy resources. Jordan has a number of potentially attractive, but uncertain, options for meeting future power recpuirements through use of domestic fuel sources. The reserves of most of these resources are unknown at the present lime, precluding a thorough analysis of the various options. However, the remaining sections review what is known about domestic energy resources crude oil, natural gas, oil shale, and renewables -- and provide a preliminary assessment of their potential use for power generation.

\subsection{POTENTIAL DOMESTIC FUEL SOURCES FOR POWER GENERATION}

\subsubsection{Crude Oil}

Approximately three-fourths of Jordan's land area is covered by sedimentary basins which are generally thought to be favorable for the existence of oil deposits. Exploration of these areas began in 1947 and, through the mid1970s, U.S., German, Japanese, French, Dutch, British, and Y'ugoslavian petroleum interests have been involved. During this time, 14 exploratory wells were drilled. Although oil and gas were found to exist in several of the wells, the international petroleum interests concluded that the size of the fields were not likely to match the ones existing in neighboring Arab countries in the Middle East. By the mid-197()s, international petrolcum interests ceased exploratory drilling in Jordan. 
The Government of Jordan (GOJ), however, was not as discouraged. Despite the disappointing conclusion of the international oil companies, the GOJ embarked on an exploration program in 1976, funded from its own resources. Through its mining arm, the Natural Resources Authority (NRA), the government examined historical geophysical data, generated new data, and marketed Jordan's potential for large-scale petroleum resources to international oil companies with the aid of British and French firms. In 1980, 20) companies were invited to review and purchase the new data. Only six companies purchased the data, but none opted for an exploration concession. The general belief was that the probability of finding a major field wass small in comparison with other exploration opportunitics.

Despite these negative responses from international petroleum interests, the COOJ has continued to maintain an ambitious oil exploration program funded out of general revenues. Expenditures for pelroleum-related researeh were at the level of $\$ 2.0$ million for 1982 and 1983 . Under the current five-year plan, 34 million JD was budgeted for petroleum exploration.

Most recently, each of NRA's 17 wells in the Hamzah region have been found to contain some oil with production levels of approximately $1,(0)(0)$ bbls/d. However, Jordan's total petroleum needs are greater than $60,(0)() \mathrm{bbls} / \mathrm{d}$. Even more encouraging to the government is its sucecss in altracting the interest of three international oil companies (Amoco, Hunt, and Petrofina) to take petroleum concessions in 1986. Although the concessions are only one well plus seismic work, the interest shown by the three international oil companies is concouraging to the government. Clearly, the price of petroleum on international markets direcilly influenees international exploration aclivity. When the concessions were taken the price did net liaver intense oil exploration efforts. However, the prospects for discovering significint amounts of crude oil in Jordan are still uncertain at the present time."11

\subsubsection{Natural Gas}

Similar to crude oil, there are insufficient geological data to speculate on the extent of natural gats reserves in Jordan. NRA has two gas wells presently in operation at Risha in the northeastern part of the country (sec Figure 4.1 above) which exhibit significant flow rates. One of the wells at Risha has been completed and tested at 20) MMSCFD (million standard cubic feet per diay).

Based on this optimistic finding, the government has committed itself to installing $2 \times 3$ (0)-MW gas turbines (to be completed by late 1988 or carly 1989) and to constructing a 132-kV transmission line over the $3.34 \mathrm{~km}$ from Amman to the Risha gas fields. In the event that the gals finds are sulficient, the government will add up) to $4 \times$ 30-MW gas turbines at the Risha fields until the 132-kV transmission capacity is reached.12

PetroCanada is currently conducting a reservoir study to ascertain the size of the reserves al the Risha site. The study is expected to be completed by carly 1989. The results of the study are crucial for energy planning in Jordan. If the reserves prove to be large, a decision must be made on the use of natural gats reserves in exeess of the anount required for power generation at the Risha site. There are several possibilities. The exeess gats could

11 In their study of the energy sector in Jordan, Meta Systems et al. used three future oil scenarios. The authors acknowledged that the scenarios were not projections or probable outcomes, but were simply plausible, based on information available in late 1987. The scenarios were reviewed and approved by the Ministry of Linergy and Mineral Resources (MI:MR) for use un the study. The base case scenario assumes that none of the three existing concessions will make commercial discoveries of crude oil. The field currently producing $1, O(x)$ bbls/d for NRA is assumed to be depleted by the year $2(x)$ ). An allemate scenario assumes that one of the current

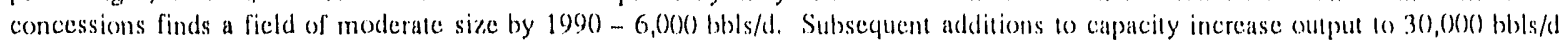
in 1995 and $40,000 \mathrm{bb} / \mathrm{s} / \mathrm{d}$ in 2000. The final scenario assumes that two fields will be developed, providing 40,000) bb/s/d in 1995 and $90,000 \mathrm{bbls} / \mathrm{d}$ in 2000$)$. The later amount represents the capacity of the refinery.

12 Comstructing a $132-\mathrm{kV}$ transmission line from Risha to Amman is an indication that the government is confident that there is at least enough natural gas in the Risha ficlds to supply $6 \times 30$ )-MW units - the $2 \times 30-\mathrm{MW}$ units currenlly under construction and $4 \times$

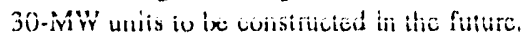


be exported. Because the Risha site is far removed from economic centers in Jordan, this could be an attractive alternative. However, the lack of export markets in the region maly preclude this possibility. Another alternative would be to transmit the gas by pipeline from Risha to the Amman area, where it could be used for industrial uses and power generation. Pipelines, however, are notoriously capital-intensive. The problem becones even more complex when nalural gals could be compeling with other indigenous energy resoures as a fucl souree in Jordan; namely, petroleum and sil shate, ${ }^{13}$

\subsubsection{Renewable Iinergy}

Recent studies on renewable energy show that the potential for wind, solar, and biogats energy in Jordan is encouraging. It has been estimated that electricity generated by the wind could tisplace 3 pereent of oil consumption in Jordan, while 8 pereent could be replaced by solar water bealers and 1 percent by biogats electric gencralors.

The potential for wind energy in Jordan is significant. I4 Up until recently, wind energy has been used mainly for water pumping. However, a joint MEMR-JEA project has been intiated for establishing a pilot 30()-kW wind farm for power generation. The farm is commected to the national grid and began generating electricity on an experimental basis in April 1988. It has been estimated that up to 10 pereent of the demand for electricity in Jordan can be mel through generation by wind turbines.

Becaluse of the high cost of photovoltaics (PV), their use as a source of energy for electricity generation is ruled out for the near future. However, PV can and is used for water pumping and communications in remote arcas where wind energy is not feasible. Several projects have been undertaken to pump underground water in desert areas where the construction of power lines is uneconomical.

In cooperation with the Royal Scientific Socicty, JEA clectrified Jurf Aldarawcish, a rural village, using both wind and solar energy. The electrification is regarded as a lest project to electrily remote villages which are a distance away from the national grid.

Biogas is currently used for electricity gencration, lighting, cooking, and running agricultural motors as a substitute for diesel. The biogas sourees include agricultural and animal wastes as well as left-over food.

\subsubsection{Oil shale}

In 1979, the Jordanian Higher Committee on Energy made oil shale development the primary encrgy priority. A special deparment to administer development of petroleum, geothermal energy, and oil shale was cstablished in the Natural Resources Authority.

In 1979, the NRA contracted with the West Cieman government to study the oil shate at El Laj.jun. The study concluded that the reserves were of high enough guality to justify indirectly using them for retorting and directly using them for power production. Sine the Sovied Union has extensive experience with using shale for power

\footnotetext{
13 The Meta Systems et al. study used four different scenarios for gas discovery, approved by MI:MR for use in llie study and developed to bracket scenaries developed by MliMR in 198\%. The base case scenario had the 20 MMSCFI of current production reduced to zero by 1995. Another scenario had production expanded (1) 50 MMSClid by 1990, increasing to 125 and 175 MMSCII) in 1995 and 2000), respectively. The third seenario had production reaching $100 \mathrm{MMSC}$ id by 1990 , increasing to 125 MMSCFD in 1995 and $175 \mathrm{MMSCl}$ ) in 20(6). The final scenario assumed that gas production would be sufficient to replace all fuel oil and provide supplies to serve the houschold and commercial sectors. Startirg from 100 MMSCFib in 1990, production would increase 10175 MMSCHD in 1995 and 250 MMSCFD in 200(). The range of these scenarios encompasses every pessible outcome for natural gas discoveries in Jordan.

14 Jordan has been rated first among devcloping comntries for developing its wind energy resources. See Strategies Unlimited,

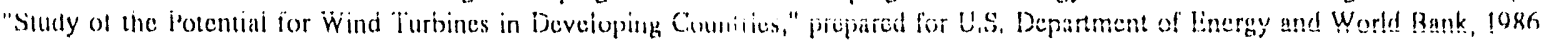


production, the NRA contracted in September, 198() with Technopromexport, a state-owned firm of the USSR, to carry out a feasibility study of directly using oil shale to luel a 30)( to 4()()-MW thermal power station. Also in 1980, a contract was awarded to Klocckner/Lurgi, a West German firm, to study the foasibility of using oil shale in Lurgi's fluidized bed combustion technology and to determine the viability of building a retorting plant to convert the oil shale to a ligutid. The German study concluded that Jordan should concentrate its efforts on retorting the shale at El Laj.jun. More recently, the El Laij.jun deposit was cored, drilled, and mapped in a joint study program sponsored by the Federal Republic of Gormany. A two-phase feasibility assessinent of syncrude oil production via mining, retorting, and oil upgrading by hydroprocessing was also conducted by the Germans and the NRA. The results of this study have not been published at this time.15

At the present time, three other shale deposits have been studied, They are the Sultani site, approximately 102 $\mathrm{km}$ south of Amman, the Jurf-ed Darawish site, approximately $35 \mathrm{~km}$ south of the Sultani site, and, most recently, a deposit north-northeast of Sultani. The four sites have proven geological reserves of more than 10) billion tons of shale. However, the estimated reserves exploitable by open-cast mining are significantly less: 1,165.9 miliion tons at El Lajjun, 942.1 million tors al Sultani, and 2,489.3 million tons at Jurf-ed Darwish. The four sites have been cored, drilled, and studied, but no data have been released about the most recently explored deposit. Possibilities for exploiting the shale include indirect use (retorting) for producing liquid fuel and direct use as a high-ash content fuel in power production. Jordan has been experimenting with both mothods.

'The remainder of this study addresses engineering, cnvironmental, and economic aspects of using the oil shale at Sultani for producing power, using a circulating lluidized bed combustion technology developed by Pyropower. Implicit in the discussion of engineering and environmental aspects of the project is that additional power generating capacity is needed and oil staale is a candidate fuel to serve that need. In the economic discussion, the use of shale will be compared with other fuels for power generation, most notably the use of cont and/or oil at the delayed Acjaba II plant.

\footnotetext{
15 Although published data on the project are not available, some results were presented at a symposium held at JisA, April 1(0)-11, 1988. The symposium, entiled Groundwater and Mineral Resources - Examples of Jordanian-German Cooperation, was sponsorod by the Goethe Institute Amman and the liederal Institute for Geosciences and Natural Resources, Hamover, West Germany, and the Jordanian Ministry of linorgy and Mineral Resources and the Ministry of Water and Irrigation.
} 


\section{CIRCULA'TING FLUIDIZED BED TECHNOLOGY}

\subsection{BASIC PRINCIPLIES}

Circulating fluidized bed (CFB) technology involves use of a special category of atmospherie fluidized bed rombustor in which (1) the combustor is ope. ated al a superficial gas velocity sufficiently high that the solid material is levilated and distributed throughout the height of the combustor with no discernible separation between a bed region and frecboard region, and (2) a hot cyclone separator is employed to return the circulating solids o the bottom of the combustor so that the solids will, on the average, make several passes through the system before leaving. In thiss high-velecity regime, a high degree of turbulence oceurs with slip between the gas and solids and internal circulation within the combustor. This yichds high combustion efficiency, low $\mathrm{NO}_{\mathrm{x}}$ cmission, good sulfur capture efliciency, and high heat transfer to the combustor walerwalls. The high lurbulence promotes good mixing of the fuel over a relatively large bed area, so that a much smaller number of fuel feed points is repuired than for a bubbling lluidized bed boiler of the same output. No in-bed boiler lubes are empleyed in the circulating fluidized bed combustor, thus avoiding tube erosion problems.

The only signifieant disadvantages of the circulating type of system are that a greater fan power (than is reguired for a bubbling atmospheric fluidized bed combustor) is needed to maintain the pressure drop through the combustor and the capital cost is somewhat higher, primarily because of the hot cyclone separator which is inherent in the design.

\subsection{THCHNOLOGY STATUS}

Fitrst introduced beginning in 1979, there have been about 75 CFil boiler plants built worldwide. They have been designed to burn a wide variely of fuels: worod waste, pealt, lignite, hiluminous coal, coal washery lails, anthracite culm, industrial wastes and sludges, petroleum coke, and others. The thermal ratting of the plants range from $2 \mathrm{MWt}$ up to 20) MWt (1 I) MWe). Aboul 30) of the plants are 20) MW or larger, while only 6 are above 150 MW. Ahlstrom and Pyropower, or through other subsidiary companies, have supplied the CFB boiler and associated equipment for about 40 of the phants which have been built. Ahlström has installed about 20) CFB boiler plants which are $20 \mathrm{MW}$ or larger, and two of these are larger than $50 \mathrm{MW}$ (55 and 110 MW). Six of the plants which are 20 MW or larger have been operating for two years or longer and 12 of them have been operating for about one year. The 55 and $110 \mathrm{MW}$ plants have been operating for less than one year.

The operalling experience with the Pyropower CFB beiler plants has been reported to be generally very good. The plants which have operated long enough to establish a record have demonstrated high availabilities, in excess of 9.5 percent. The technology appears to have been suecessffully demomstruted in units as large as up to about 60) MW. There are no indications that there should be any problems in demonstrating suecessful operation of larger plants. The $55 \mathrm{MW}$ plant was sold on a commercial basis, and it is anticipalted that it will operate satisfactorily. The largest plant, $110 \mathrm{MW}$, is a ulility demonstration plant at whicia the Electrie Power Research Instilute (EPRI) is conducting a 2 -year test program to demonstrate the feasibility of CFB boilers for utility applicalions.

The Jordanian oil shale, because of its high ash content, is a more challenging fuel than, saly, bituminous coal for use in scaling up) (o larger plants. The large guantities of ash which will be circulated through the combustor and relurned by the hot cyclone will place a heavy demand on the return leg and loop seal. Also, there will be heavy fly ash loading in the llue gas passing through the convection tube banks, with increased potential for problems with crosion or deposition. 


\subsubsection{Plant Visits}

In order to gain information on the operating experience of the Ahlstrom-Pyropower CFB plants, tours were laken of two plants: the $80 \mathrm{MWl}$ (about ecquivalent to a $2.5 \mathrm{MWe}$ plant) district heating plant at Espoo, Finland, and the $110 \mathrm{MW}$ utility demonstration plant al Nucla, Colorado. The tour of the Espoe plant was al the invi. tation of Ahtstrobn during the lime that the fuel combustion evaluation team was present for the Jordanian oil shale combustion tests al Karhula, Finland.

\subsubsection{Espoo plant}

The boiler is rated at $80 \mathrm{MW}$ and produces hol water at $1800^{\circ} \mathrm{C}$ and a pressure of 9 bar. The primary water is circulated through a heat exchanger where heal is transferred to waller which is sent through the city district heating distribution system. The circulating fluidized bed combustor and hoiler were designed and built by Ahlstrom. Coal is the fuel burned and limestone is added for $\mathrm{SO}_{2}$ capture. The unit was commissioned an 1986 and has opcrated satisfactorily. It is an add-on unit 10 a larger pulverized coal-fired cogeneration stoam plant for electric power and district heating which has remained in operation.

\subsubsection{Nucla CFB demonstration plant}

The plant is owned and operated by the Colorado UTE Electric Association and is a joint demonstration project with the Electric Power Research Institute (EPRI) and scveral ceoperating sponsors. 'This is the workl's largest operating CFB boiler. The three original coal-fired stoker boilers, each rated at $12 \mathrm{MW}$, have been retired in place. The new CFB boiler, rated at $110 \mathrm{MW}$, produces all the steam and a new $74 \mathrm{MW}$ topping steam turbinegenerator has been added to operate in series with the three original turbine-generators, rated at $12 \mathrm{MW}$ each, to produce the full plant output.

The CFB boiler, designed and supplied by Pyropower Corp., produces $925,(0)(0) \mathrm{lb} / \mathrm{h}$ of superhealed steam at 1510 psia and 54()$^{\circ} \mathrm{C}$ for the nonreheat steam turbine cyele.

The boiler has two combustion chambers, adjoining with a common center separation walcrtube wall, cach a little more than 2()-ft suluare and about 130-ft lall. Each combustion chanber has watertube walls and a superheater tube bank arranged around three of the four walls near the top of the combustion chamber. There is a hot cyclone separator for each of the two combustion chambers. The eyclone separators are designed to remove about 95 percent of the solid particles above 9) $\mu$ in diameler. The flue gas from the two cyclones flows to a single convection pass, where the gals flows down over final (tertiary) and primalry superhealer tube banks and then economizer tube banks. The flue gals then flows through the tube side of a vertical-tube air preheater and then to a baghouse.

Solids removed by the hot cyclones are returned to the bottom of the combustion chambers through loop seal legs which are fluidized by a number of air nozales to maintain solids relurn flow.

Coal is fed through two feed-points on the front wall of each combustion chamber and at one feed-point on each of the solids return line just before the return entrance to the combustion chamber. Limestone is fed through four feed-points on the walls of each combustion chamber.

Primary (fluidizing) air is supplied to the boltom air plenum and enters the combustion chamber through a large number of fluidizing air nozales which have several small holes drilled around the side of each nozzale. The floor of the combustion chamber (which also serves as the top of the air plenum) consists of a welded membrane watertube wall with the floor sloped loward two walls from the center, with the air noziles altached to the membrane fins between water tubes. Secondary air is supplied through the wall to each combustion chamber at an elevation a few feet above the coul feed points. The ratto of primary/secondary air normally used at full load 
is 70:30. Overall, the excess air used is cnough to yicld about 3.5 percent $\mathrm{O}_{2}$ in the llue gas, or about 17 pereent excess air.

At full load, the combustor operales at a chamber pressure of approximately 35 to 40 in of $\mathrm{H}_{2} \mathrm{O}$ at the bottom and a temperature of approximately $9(x))^{\circ} \mathrm{C}$. A combustion elficiency of $99^{\prime}$ percent and a boiler effleiency of approximately 86 percent have been achicved. The environmental regulations reculde an $\mathrm{SO}_{2}$ removal of 80 percent to stay under a limit of (0.3 lb/MBtu. Limestone is fod alt a rale of approximately (0.1 ton/ton of coal with a mean particle size of approximately $150 \mu$ to control $\mathrm{SO}_{2}$ cmissions. Low levels of $\mathrm{NO}_{x}$ emissions have been achicved.

Ash and spent limestone are discharged from the side of cach combustion chamber into two ash-cooler-clatssiflerrecycle units. Fluidizing air is supplied to these units which causes the finer particles to rise and return to the combustor. The larger particles travel down around walcreosled tubes which permits uselul recovery of heat from the ash into the water-steam cycle. The cooled ash lalls through rotary valves and into water-cooled screw conveyors which feed it to the ash disposial system.

Coal and limestone are delivered by truck to the plant. The conl is sized about 2 in $x(0$ as received. The coal analysis is in this range:

$\begin{array}{ll}\text { HHV, Bu/llb } & =94(0)-10,4(0) \\ \% \text { Sulfur } & =0.68-0.8 \\ \text { \% Ash } & =20-23 \\ \text { \% Moisture } & =5.10\end{array}$

Coal is crushed to $1 / 4$ in $\times 0$ and sent to the lecd hopper. From the feed hopper it is fed by weighbelt feeder through a rotary valve into the combustion chamber. Coal consumption is about 62 tons/h al lull load.

Limestone is received with a top size of 12 to 14 in. From the storage pile it is sent to a crusher whice it is crushed to $150 \mu$ mean size and dried with a gats-fited heater. It is sent to the feed hopper which discharges through four rotary valves into the four pneumalie feed lines to each combustion chamber. The limestune fecd rate is metered by the time differential weight of the feed hopper.

Gas burners are used for startup. Each combustion chamber has 3 startup gas burners through the wall and one duet gas burner for preheating the air during startup. They preheat the air to approximately $427^{\circ} \mathrm{C}$ with the duct burner. They use a startup bed of spent bed ash about 4 ft deep. They lire gas to make enough steam to get the turbine generators synchronized at minimum load and to get the bed temperature up to $510^{\circ} \mathrm{C}$. Al this temperature they begin feeding coal, and it lights ofl easily at that point. They can go from a cold start to operating solely on coal in about $12 \mathrm{~h}$. The boiler is designed for a $3:$ I turndown on coal firing. The stcam exit temperature is controlled by attemperator water spraty ahead of both the secendary and final superheaters.

Variable speed AC motor drives are used on the primary, secondary, and induced draft fans. The primary air fan has a 35()()-hp motor and the secondary air fan has a 7()()-hp motor. The two fans supply the combustion air for both combustion chambers. Separate high pressure blowers are used to supply higher pressure air for fluidizing the loop seal legs and ash coolers and air for pneumatic tansport.

The plant was shut down for minor repairs and modifications at the time of our visit. One problem has been a tendency for instability of the water level in the steam drum. There is a single common stean drum which serves the boiler tubes of both combustion chambers, which may conceivably contribute to the water level instability if the boiling rate were different in the two chambers. A totally random incident occurred in the fall of 1987 in which during startup a surplus of coal accumulated in the "A" combustion chamber and then began 
burning rapidly causing the chamber to overheat to a temperature of about $1038^{\circ} \mathrm{C}$. This caused Jamage to the waterwall tubes in the common partition wall between the chambers due to the large differential thermal expansion. This damage was repaired immediately thereafter and no further overheating problems have been encountered.

Visual observation of the inside of the hot cyclone separators revealed no apparent significant slag buildup. There were heavy deposits of loose, fine lly ash on the top surfaces of the convection tubes, which have a horizontal orientation. Soot blowers are not used on the superheater tube banks but on the economizer and air heater lubes only. The plant's operators have had some restrictions of solids flow or plugging in the cyclone return legs, and they have had indication of some regions of poor fluidization in the loop seal legs and are adding a number of additional fluidizing air nozzles in those regions.

The normal flue gas temperature at the baghouse is about $163^{\circ} \mathrm{C}$ at full load. The plant operators use teflon coated filter bags. The stack gas environmental monitoring equipment is located at ground level after a long horizontal duct run and just at the entrance of the stack.

The capital cost for the CFB boiler and turbine-generator plant addition was about $\$ 87$ million. This includes all the new ancillary equipment required and a new control room with a microprocessor computer control system. The present coal price is $\$ 24-28 / t$ on. The present operating stalf is 32 persons, but the plant managers are adding 2 heavy equipment operators to the staff. The normal outage for their scheduled annual shutdown is 3 wecks. The rotary vaives in the coal, limestone, and ash systems normally can sperate for at least a year without having to be shut down for an overhaul.

\subsection{SUMMARY OF COMRUSTION TESTS OF JORDAN OIL SHALE}

The combustion tests of the Jordan oil shale were conducted in the Ahlström CFB test unit at their R\&D Center at Karhula, Finland from January 11-20, 1988. The test program consisted of a series of runs in which one or more of the key operiting parameters was changed for each run so that the effects on the combustion performance could be determined.

Details of the test burn results have been reported to AID by both Pyropower Corporation and by ORNL. These details are proprictary to Pyropower and interested partics will have to contact Pyropower to discuss access to such information.

The Jordanian oil shale burned very well, even at loads as low as 40 percent. A large fraction of the shale blows through the combustor as fly ash; therefore, a large portion of the ash will have to be disposed of as fine fly ash. Low $\mathrm{SO}_{2}$ and $\mathrm{NO}_{x}$ emission levels can be achieved in the circulating fluidized bed combustor, utilizing the calcium present in the shale and requiring no sorbent or chemical additives. High carbon burnup, 98 percent or belter, can be expected. 


\section{MINE AND SHALE OIL-FIRED GENERATING PLANT DESIGN}

The proposed project is adjacent to the Desert Highway, with $400 \mathrm{kV}$ and $132 \mathrm{kV}$ power lines located just to the west of the highway. The national railruad line lies east of the highway and runs directly through the north pit area of the Sultani deposit. This rail line must be located to proceed with the $4 \times 100 \mathrm{MW}$ oil sahle project. Plans are to expand the existing test mine pit at the northwest corner of the deposit and develop the pit to the southest. Shale processing facilities, power block facilities, office and service facilities all would be located to the west of the mine pit, between the mine and the highway. Water wells to the upper aquifer would be drilled in the vicinity of the power plant. (See Figure 6.1.)

\subsection{MINE AND MATERIALS HANDLING SYSTEMS}

The 400-MW Sultani oil shale-fucled power plant would be a large operation, with materials handling issues made even more important than in most such large operations because of the high-ash nature of the performance fucl. As mentioned in the Bechtel Group's project plan, the need for a 50-MW step is more for answering questions centered on "design issues for optimizing a 10)-MW plant, in particular materials flow, rather than any need to prove the technology feasibility." Oil shale is harder than salt or coal, so mining and material handling equipment developed for these commodities are not necessarily directly applicable to oil shalc.

If the proposed plant $(400 \mathrm{mw}$ ) were to be built, each year mine operators would extract approximately 7.78 million tonnes of oil shale after removing 10 million bank $\mathrm{m}^{3}$ of overburden. The design rate of the mining operation (perhaps overly conservative) is 2,00() tonnes of specification fuel per hour based on a $1(0)$ percent capacity factor of the power plant ${ }^{1}$ and a 72 percent efficiency factor for the mining operation.

\subsubsection{The Oil Shale Resource}

Jordan has long been identified as having extensive oil shale resources, possible exceeding 10 billion tons. There has been extensive core drilling by the NRA at four shale deposits in the country. Table 6.1 summarizes these oil shale resuurces for three of the sites, with 3 to 4 billion tons readily accessible for development. The fourth, not displayed here, is the most recent exploration effort and the most extensive reserve yet. It is located 4() to $55 \mathrm{~km}$ north-northeast of the Sultuni site. Data on the size and quality of this reserve have not been published yet.

The Sultani site's nearly one billion tons of reserves cover an area of about $25 \mathrm{~km}^{2}$. The Bechtel Group, Inc. has calculated that oil reserves in the northern area alone of the Sultani site appear to be sufficient to support a $40($ )-MW plant for 30 years. With reserves in the southern area of the deposit being more than twice as large, the Sultani site could theoretically support up to 120) MW of power generation for 30) years.

\footnotetext{
1 A capacity factor in the 601070 percent range would be more realistic.
} 


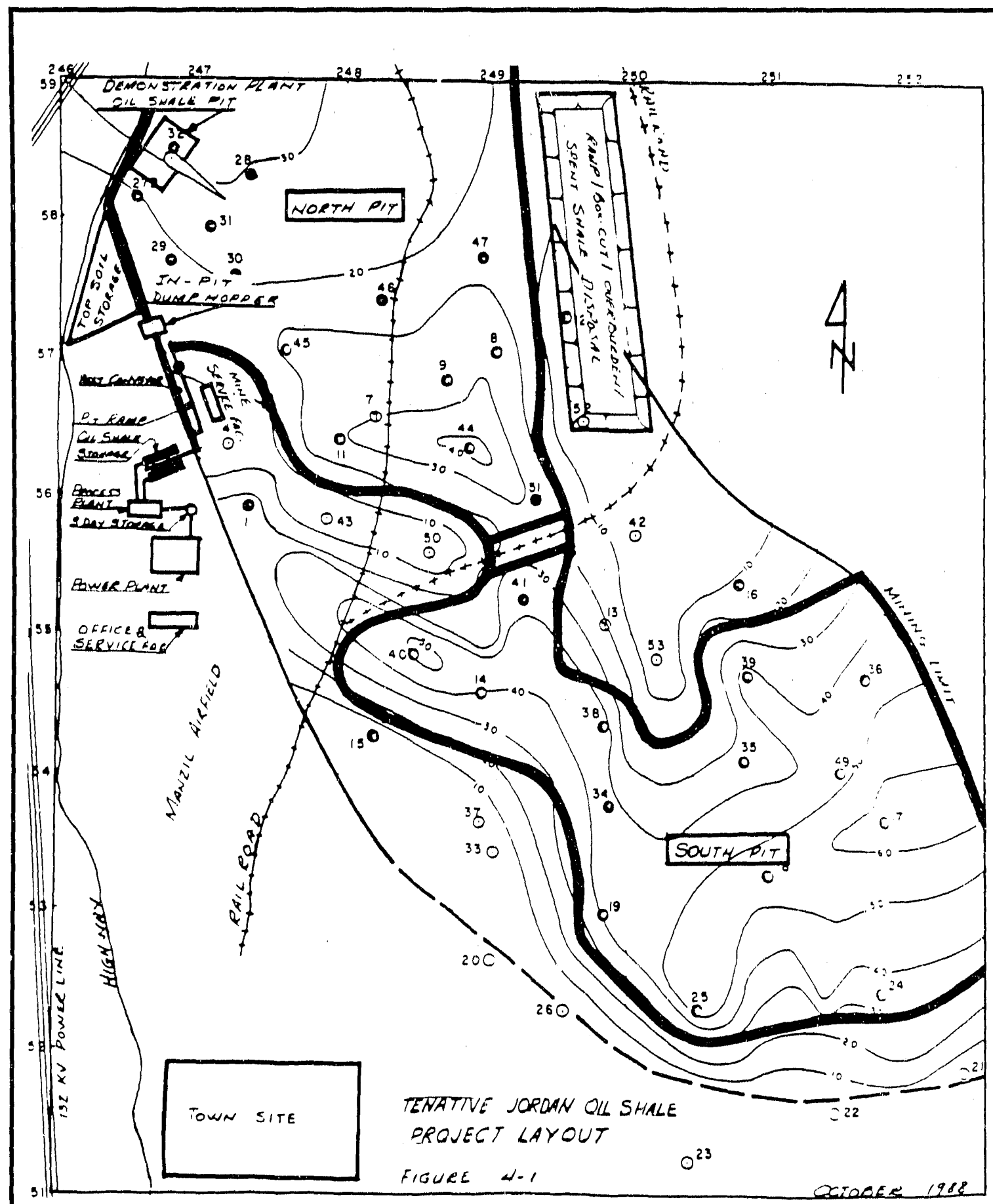

Figure 6.1 Proliminary Iordan oil shale project layout (Source: Bechtel National, Inc... Arlington, VA) 
Table 6.1 Jordan oil shale reserves

\begin{tabular}{lccc}
\hline & El Laijun & Sultani & $\begin{array}{c}\text { Jurf-cd } \\
\text { Drawish }\end{array}$ \\
\hline $\begin{array}{c}\text { Exploitable resources } \\
\text { (billion tons) }\end{array}$ & 1.2 & 0.9 & 2.5 \\
$\begin{array}{c}\text { Oil shale thickness } \\
\text { (mean average in m) }\end{array}$ & 29.6 & 31.6 & 68.3 \\
$\begin{array}{c}\text { Overburden thickness } \\
\text { (mean average in m) }\end{array}$ & 25.8 & 69.3 & 47.3 \\
$\begin{array}{c}\text { Shale oil content } \\
\text { (mean average by \% weight) }\end{array}$ & 10.5 & 9.7 & 5.7 \\
\hline
\end{tabular}

Source: Prefeasibility' Study: Oil Shale Utilization for Power Production in the Ilashemile Kingdorn of Jordan, Volume l, Bechtcl National, Inc., Ailington, VA, December 1988.

\subsubsection{Drilling program}

A total of 53 holes on approximately $1-\mathrm{km}$ centers were initially drilled at the Sultani site to delineate the reserves (26 holes in 1982 and 1983 by the NRA and the BGR of the Federal Republic of Germany, and 27 holes by the NRA in 1986). An additional 28 drill holes on 150-m spacings were recently completed and used to define the reserves in the northwest section of the site, the area proposed for initial production mining. The oil content was determined in 67 of these holes (Fisher analysis on 42 boreholes), and analyses for calcium carbonate, sulfur, inorganic carbon, and organic carbon content were determined for 15 drill holes.

Based on the borchole drilling, the following geologic maps were made of the Sultani deposits: structural contour map of the upper oil shale surface, structural contour map of the lower oil shale surface, isopach map of the overburden, isopach map of the oil shale, and isoline map of the oil content percent.

\subsubsection{Borchole Analysis}

Table 6.2 summarizes the extent of the Sultani oil shale reserves, based on mineable reser'e critcria that cmploy reserves having a greater than 5 percent oil content and a stripping ratio of overburden volume to oil shale volume of less than 3:1. The mineable reserves are in two distinct areas, one in the north and one in the south, separated by a narrow corridor of low-grade oil shale in the central part of the deposit. The Bechtel Group, Inc. used a specific gravity of 1.8 in determining the quantity of oil shale.

Table 6.2 Sultani oil shale reserves

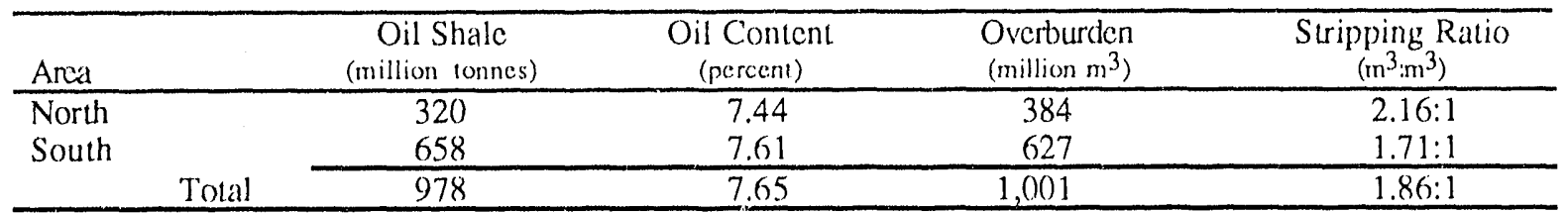

Source: Prefeasibility Study: Oil Shale Utilization for Power Production in the Hashemile Kingdom of Jordan, Volume II, Appendix

5, Beche! Nationa! Inr. Arlingion, VA, December 1988. 
Table 6.3 summarizes the mineable oil shale reserves by their oil content. The thicker oil shale beds contain a higher percentage of oil. The average organic content of the oil shale tested ranged between 8 and 11 percent by weight.

Table 6.3 Sultani oil shale reserves by oil content (in mlllion tonnes)

\begin{tabular}{clllllll}
\hline Area & $5 \%$ Oil & $6 \%$ Oil & $7 \%$ Oil & $8 \%$ Oil & $9 \%$ Oil & $10 \%$ Oil & Total \\
\hline North & nil & 24.440 & 158.075 & $114.4(0 \%$ & 23.407 & - & 320.329 \\
South & 2.075 & 82.416 & 238.067 & 186.870 & 144.420 & 4.750 & 6.58 .598 \\
\hline Total & 2.075 & 106.856 & 396.142 & 301.277 & 1.67 .827 & 4.750 & 978.927 \\
\hline
\end{tabular}

Source: Prefeasibility Siudy: Oil Shale Utilization for Power Production in the Hashemile Kingdom of Jordan, Volume II, Appendix 5, Bechtel National, Inc., Arlington, VA, December 1988.

\subsubsection{Oil Shale Composition and Propertics}

Table 6.4 summarizes the physical composition of the oil shale in terms of its usability as a fuel. The sulfur content varies between 1.6 and 4.3 pereent, with most values between 2 and 3 pereent.

Table 6.4 Sultani fuel specification

\begin{tabular}{|c|c|c|c|c|}
\hline Composition (\% by wt.) & & $\begin{array}{l}\text { Low Calorific } \\
\text { Value Fucl }\end{array}$ & $\begin{array}{l}\text { Performance } \\
\text { Fucl }\end{array}$ & $\begin{array}{l}\text { High Calorific } \\
\text { Value Fuel }\end{array}$ \\
\hline Carbon (organic) & & 10.20 & 11.32 & 12.50 \\
\hline Carbon dioxide & & 14.14 & 13.87 & 13.37 \\
\hline Sulfur & & 2.38 & 2.55 & 2.71 \\
\hline Moisture & & 3.20 & 3.20 & 3.20 \\
\hline Hydrogen & & 1.02 & 1.13 & 1.25 \\
\hline Nitrogen & & 0.58 & 0.48 & 0.38 \\
\hline Oxygen (by difference) & & 1.18 & 0.65 & 0.34 \\
\hline \multirow[t]{2}{*}{ Ash } & & 67.30 & 66.80 & 66.25 \\
\hline & Totals & 100.00 & 100.00 & 100.00 \\
\hline HHV (Btu/pound) & & 2000 & 2250 & 2500 \\
\hline $\begin{array}{l}\text { Fisher Assay Oil Content } \\
\text { (\% by weight, median) }\end{array}$ & & 7.5 & 8.4 & 9.25 \\
\hline Range (\% by weighl, median) & & $6.7-8.3$ & $7.5-9.0$ & $8.4-9.9$ \\
\hline
\end{tabular}

Source: Pyropower Corporation, April, 1988.

\subsubsection{Mining Considerations}

The overburden thickness ranges between $34 \mathrm{~m}$ and $86 \mathrm{~m}$, with a mean thickness of $69.3 \mathrm{~m}$. The minimum thickness is found in the northwest part of the deposit and the maximum is in the southeast. The oil shale thickness varies between $1.5 \mathrm{~m}$ and $65 \mathrm{~m}$, with a mean thickness of $31.6 \mathrm{~m}$. The greatest thickness oceurs in the southeast section of the reserves. 
The mine development plans for the 20-MW and 5()-MW projects are different from those of the 400-MW plant because of the much larger volumes of materials to be handled in the full-scale commercial project. The mine for either of the two smaller projects would be formed as an expansion of the existing trial pit through use of a loader and truck operation. Working benches and a system of roads and ramps would be developed in the overburden and oil shale in preparation for actual production. Three separate haul roads would be built to transport (1) overburden from the pit to an out-of-waste pile located $3 \mathrm{~km}$ away, cast of the oil shale deposit, (2) oil shale from the pit to the process plant storage piles (3 km), and (3) spent shale ash from the power plant to the out-of-pit waste pile $(4 \mathrm{~km})$.

The mine for the 400-MW project would be new, also being located in the northern part of the site because of its thinner overburden along the west bank of the deposit. Complete development of this are for mining would entail the necessity of relocating an existing railroad line (the Hijaz Railway) after about 18 or 19 years. The mine would consist of a new incline and box-cut, the development of working rock faces for electric shovels and tricks in the in-pit-system of roads and ramps. Mined shale would be fed onto a belt conveyor for transport to the surface via the incline. For the first several years of the operation, the incline would be used for transport of overburden from the pit to the out-of-pit waste pile. After sufficient mining has been completed (approximately three years) to permit room in the pit, backfilling of the pit could be started. Haulroads for the disposal of the overburden and of the spent shale would have to be built at that time.

\subsubsection{Mode of mining}

The mine operation consists of the following activities:

- topsoil removal and storage

- loading and hauling of overburden for disposal to out-of-pit waste pile

- ripping oil shalc

- storing oil shale in two piles by grade

- crushing and hauling to power plant stockpiles
- drilling and blasting of overburden benches

- leveling waste pile

- selective mining of oil shale with scrapers

- reclaiming in approximate fuel specification mix

\section{Truck and shovel mining}

Mining at the proposed Sultani oil shale plant would be by mobile mining equipment, i.c., "truck and shovel." The overburden for the mines for the 20)- and 5().MW projects would be removed (after being loosened by blasting) by front-end loaders, while that of the 400-MW plant would be loaded by electric shovels. Mining of the oil shale for the two smaller mines would be by using bulldozers to rip the oil shale and scrapers to load the ripped shale for delivery to the portable crusher. In the 40)()-MW project, surface miners would be used to load the broken shale into trucks for delivery to trump dump hoppers. Explosives used to break up the overburden will be detonated by use of blasting delays between rows of holes and occasionally between holes in the same rows to improve fragmentation and reduce ground vibration and air blast levels. On-site, secure explosive storage will be provided for bulk blasting agents, bagged ANFO (the primary explosive), and high explosives. Construction of these would be in accordance with appropriate standards. Access to the blasting areas would be controlled prior to the time of blasting.

\section{Dragline mining}

The El Abïad Mine has a stripping ratio of $9.6 \mathrm{~m}^{3}$ of overburden to $1 \mathrm{~m}^{3}$ of phosphate ore mined. In order to reduce overburden excavation costs, in 1981 the Jordan Phosphate Mining Company Ltd. (JPMC) procured a $30-\mathrm{m}^{3}$ dragline (the first large dragline in the Middle East) for its El Hasa operations $(20 \mathrm{~km}$ 
south of the El Abiad Mine). An intcrnational mining contractor operated it for the first two ycars. Dragline production, operation, and availability proved most satisfactory, and JPMC took over the dragline operation in 1983. To reduce contract mining costs for overburden excavation, JPMC has since procured a $17-\mathrm{m}^{3}$ dragline for its operations at $\mathrm{El}$ Abïad Mine and is procuring several other small draglines for its operations elsewhere. Technical questions about Jordanian engineering and maintenance capabilities to keep such capital-intensive machinery in operation are, thus, largely moot based on JPMC's record. JPMC estimates that a dragline employed in the Sultani mine could reduce overburden excavation costs by about 50 percent.

The questions that do remain about the suitability of a dragline al the Sultani site are (1) the possibility of the incremental nature of mine and plant expansion (to match demand for power) vis-à-vis the capital intensive, one-time cost of procuring a dragline; and (2) the length of the boom necessary to allow the bucket acesss to the lowest-lying overburden. The relatively flat shale oil beds are highly conducive to dragline removal of overburden. Preliminary discussions with personnel2 from the Bucyrus-Eric Company, suppliers of the $17-\mathrm{m}^{3}$ dragline at the El Abrad Mine, suggest that a dragline would be easily suited to operating under the physical mining demand needs and constraints of the planned Sultani operation. The main question would be the phasing of the operation.

Additional information regarding the feasibility of using draglines and information on other aspects of the mining and materials handling operations can be found in Appendix B.

\section{Oil shale handling}

Because of the performance specification of the fucl (225) Blu per pound), separation of the ore must occur. In the case of the two smaller mines, oil shale would be placed in both low-and high-grade stockpiles by the scrapers according to visual inspection of grade by the equipment operator (sec Figure 6.2). A. front-end loader would charge a portable crusher from these stockpiles. From the crushers, the ore would be transported by truck from the pit to the surface oil shale process plant stockpiles. While one stockpile would be in the process of being formed and tested, the second would be used to fuel the plant with the aid of another front-end loader. The requisite fuel is thus assured through use of selective mining, mixing at the portable crusher, and amendment from the stockpile prior to use in the plant.

For the 4())-MW plant, oil shale would also be selectively mined and loaded through use of surface miners and trucks which would carry the ore to truck dump hoppers (see Figure 6.3). From the hoppers, the oil shale would be moved to the surface via belt conveyor where it would enter an automatic sampler before being placed on at traveling stacker for stockpiling into two "V" slot storages. White one stockpile would be formed and tested, the second would be amended be two variable speed plow feeders for delivery to the process plant. This system would assure the large volumes of uniform-quality oil shale necessary for the large operation.

\subsubsection{Production of phosphate to reduce the mining costs}

The NRA's recent core drilling to further define the oil shale reserve revealed that the Al Hasa Phosphorite Formation, which underlies the Sultani oil shale, has 3 to $12 \mathrm{~m}$ of phosphorite material. These deposits

\footnotetext{
2 Martin 1. Selfer, Manager, Drive and Power Systems, and Rami Beydoun, Electrical Engincer, Service Division. Since neither is a mining engineer, these observations will have to be confirmed by someone more familar with the specifics of the proposed Sultani mining operation.
} 
MINE AND SIIALE OIL-FIRED

GENERATING PLANT DESIGN

page 6.7

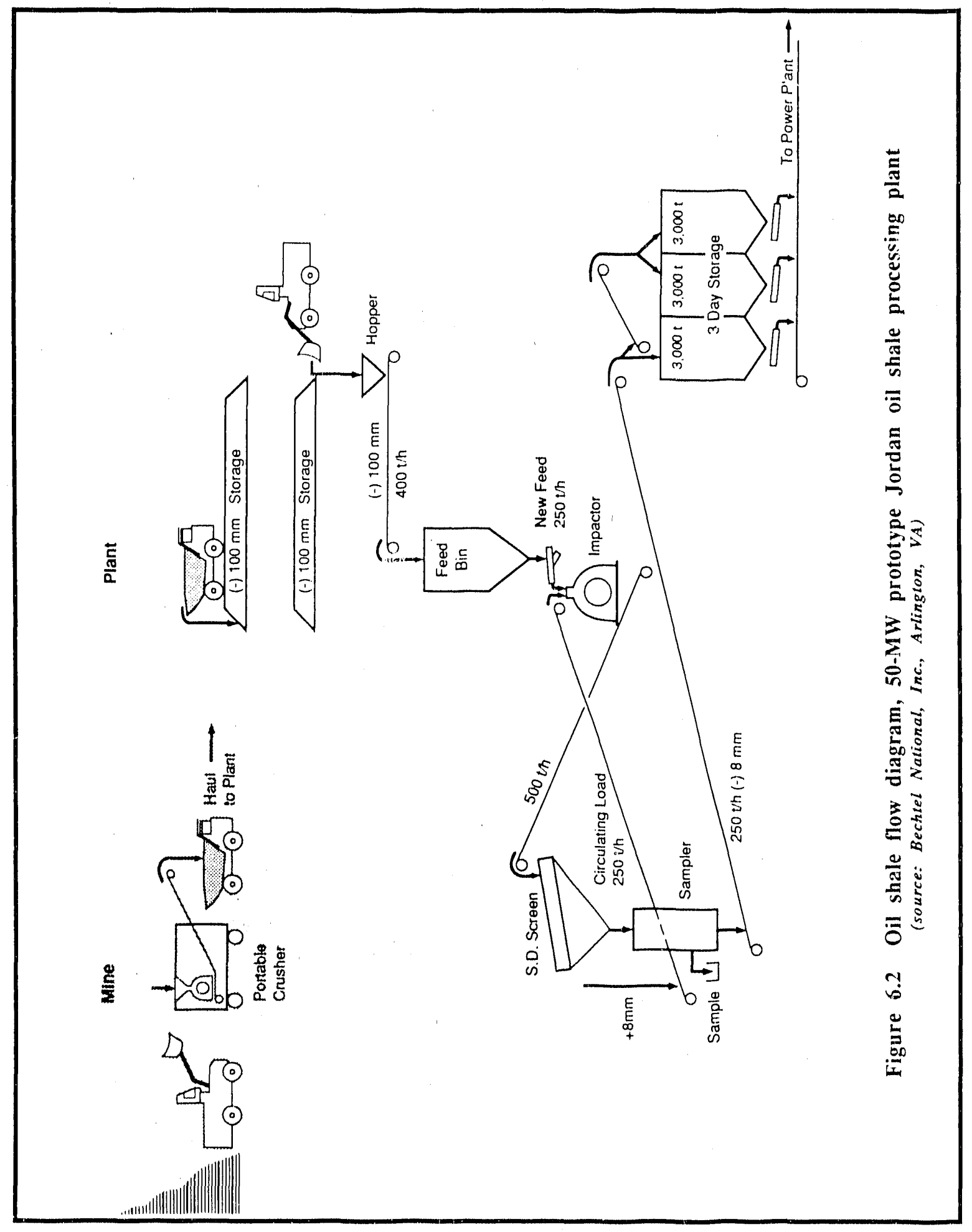


are unexplored in the Sultani area, but are part of the phosphate ores currently being mined in the large operations of El Abiad and El Hasa south of the Sultani area.

With a world market oversupply of phosphate rock and Jordan having ample supplies of inexpensively mined phosphates, there appears to be little incentive to mine decper below the oil shale for what is likely low-grade phosphoritic ore. The overburden removal costs are, of course, nil, but the costs of removing overburden in the large phosphate pits mined by draglines are not that expensive a part of the overall mining and mill operations. With the 1992 (or thereabouts) closure of the El Abïad Mine and the El Hasa operation planned to be terminated in 1997 (due to their limited remaining proven economically recoverable reserves), there would be no nearby beneliciating or milling operations for any phosphate ores mined at Sultani. Extensive and expensive transportation costs would have to be incurred to pursue this option.

On April 18, 1988 in Jordan, we asked Mr. Muhammed Abu Ajamich, the Director of Geologic Surveys and Mines in the NRA, about the potential for mining the phosphate rocks underlying the oil shale. He responded that the phosphoritic horizon is composed of very hard rocks, meaning that exploration of its extent and feasibility for mining would likely be expensive. He stressed that Jordan has many phosphate deposits that are readily mineable, there is a current glut in the international market for phosphate rock, and that there is much uncertainty associated with the mere presence of mineable ore. These uncertainties include quality issues, means and costs for beneliciation, and marketability. The fact that the phosphate reserves would be accessible without any costs to remove the overburden did not impress Mr. Abu Ajamich. He held out little optimism or interest in NRA exploiting this potential.

Of course, what the marke for phosphate rock might be by the mid-199)s when the oil shale project might first begin operation is another question. The World Bank clearly has some confidence in Jordan's potential to export phosphate on the world market at that time, given that the Bank is about to fund a $\$ 31$ million loan to the JPMC for a new phosphate mine and processing plant at Shidiya, $120 \mathrm{~km}$ northeast of Acaba.

Another consideration in conjunction with the El Abiad and El Hasa Phosphate Mines being scheduled to close in the 1990) is that the raw rock would have to be transported to the Shidiya site, a considerable distance. (The existing narrow-gauge Hijaz Railway, which is used to transport the production from the EI Abiad and El Hasa complexes and also connects with the Sultani site, passes $25 \mathrm{~km}$ west of the Shidiya site. There are no current plans to make the link between the Shidiya site and this railway, although the World Bank states ${ }^{3}$ that "The proposed Transport III project may envisage the extension of the railway line to Shidiya, depending on the economic and financial justification of this extension." The narrow gauge line between the El Hasa and El Abiad mines suffers from the poor condition of the existing track and bed, and occasional derailments occur because of poor track maintenance. In 1986, only 48 percent of the output of these two production facilities was transported to Acjaba by rail; the rest went by contract trucking operations, whose tariffs per tonne were more attractive than the railroad's rates.)

\subsection{SHALE OIL-FIRED GENERATING PLANT DESIGN}

Pyropower has prepared a preliminary design of shale oil-fired CFB boilers for nominal 20-MW and 50-MW electricity generating plants. The designs are very similar except for the differences necessitated by the

\footnotetext{
3 The World Bank, Staff Appraisal Report, Lashemite Kingdom of Jordan, Shidiya Phosphate Mine Project, Energy Division, Asia Technical Departmem, The World Bank, Washington, D.C., Report No, 6932-JO, restricted distribution document, December 18, 1987.
} 


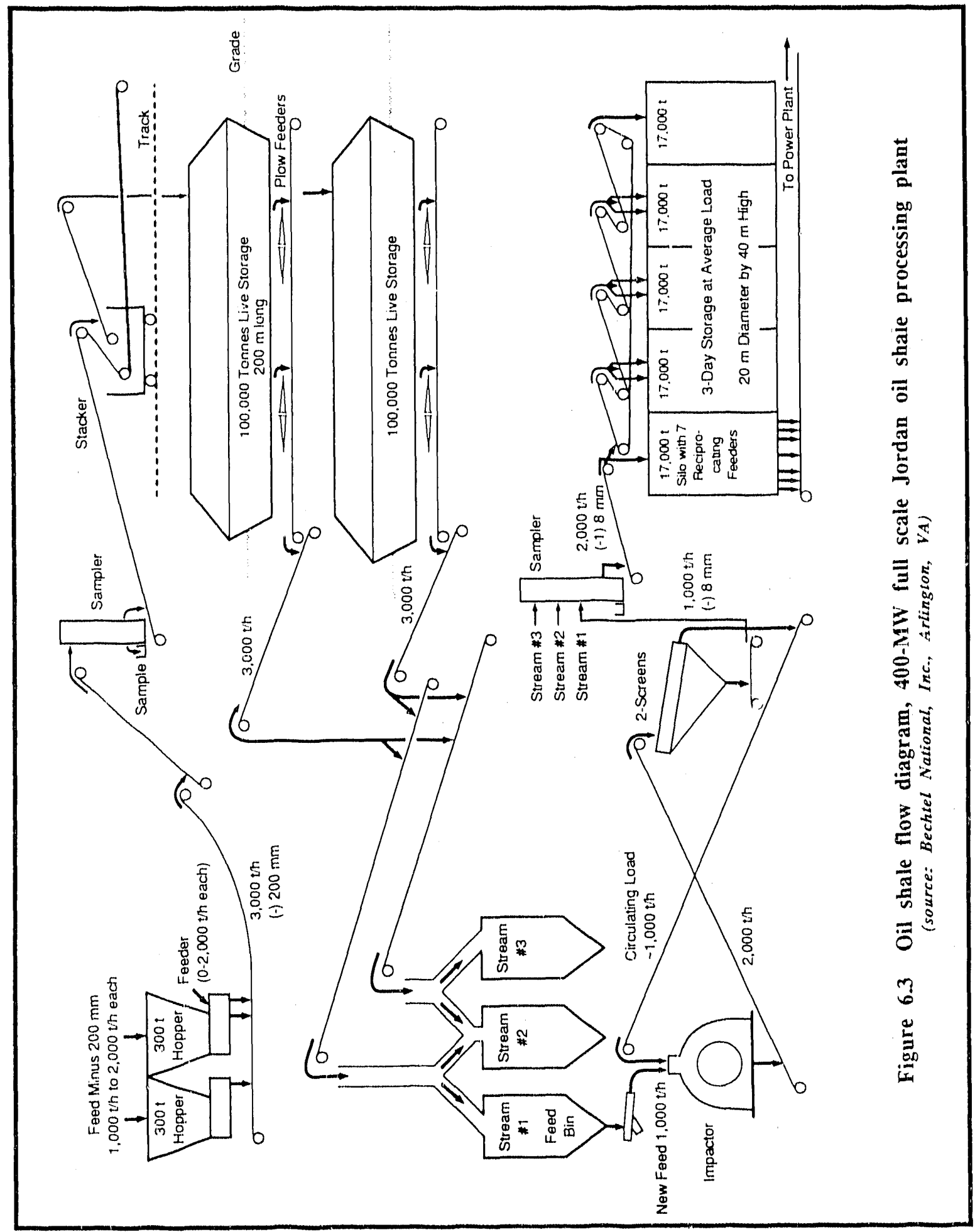


difference in capacity, The princlpal design parameters for the two boilers are proprictary in nature, and Pyropower would have to be contacted regarding availabilley. ORNL has analyzod these deslgns for their feasibility and has reported lts findings to AID and olher study participants. ORNL's analyses are also proprietary in that they necessartly convey elements of the Pyropower design which are protected by conlidentiality agrements. Figure 6.4 gives a schematic representation of the whole ofl shale-for-power project.

The major socioeconomic and environmental impaces from the proposed project will come from meeting the project necds summarized in T'able 6,5.

'lable 6.5 Operating characteristics, three plant-state operations, sultanl ofl shate project

\begin{tabular}{|c|c|c|c|}
\hline Chatracteristic & $20 \mathrm{MW}$ & $50 \mathrm{MW}$ & $4(0)(4 \times 10(0) \mathrm{MW}$ \\
\hline Oil shale fuel $(1 / y)$ & $390,0(0)$ & $973,(0)(0)$ & $7,80(0,0)(0)$ \\
\hline $\begin{array}{l}\text { Mine Development excavalion ( } \\
\text { bank } \mathrm{m}^{3} \text { ) }\end{array}$ & $5(0)(0,0)(0)$ & $1,(0)(0,0)(0)$ & $8,500,0(0)$ \\
\hline $\begin{array}{l}\text { Spent ash disposial } \\
\text { (1/y, wetted })\end{array}$ & $327,00(0)$ & $81.5,(0)(0)$ & $6,10(0,0)(0)$ \\
\hline $\begin{array}{l}\text { Water consumption } \\
\qquad\left(1000 \mathrm{~m}^{3 / 4} \mathrm{y}\right)\end{array}$ & 538 & $9(07$ & 126.3 \\
\hline $\begin{array}{l}\text { Net power production } \\
\text { (million } \mathrm{kWh} / \mathrm{y})\end{array}$ & 158.7 & 398.8 & $(3234.5)^{a}$ \\
\hline - Total power gencration & 24,0 & 60.4 & $(483,5)^{a}$ \\
\hline $\begin{array}{l}\text { - Power block operating consumption } \\
\text { - Power used for shale mining and }\end{array}$ & 7.2 & 7.4 & 123.0 \\
\hline shale processing & 127.5 & 331,0 & 2628.0 \\
\hline - Net power to National Girid (MW) & 19.4 & 5()$, 4$ & $4(0), 0$ \\
\hline Operating personnel & 18.5 & 324 & 1046 \\
\hline Community population & $7(0)$ & $12(0)$ & $400(0)$ \\
\hline
\end{tabular}

Source: Prefeasibility Simdy: Oil Shale Utilization for Power Production in the Mlashemile Kingdom of

Jordan, Bechtel National, Ine, Arlington, VA, Maty 19k').

"liactored escimate 


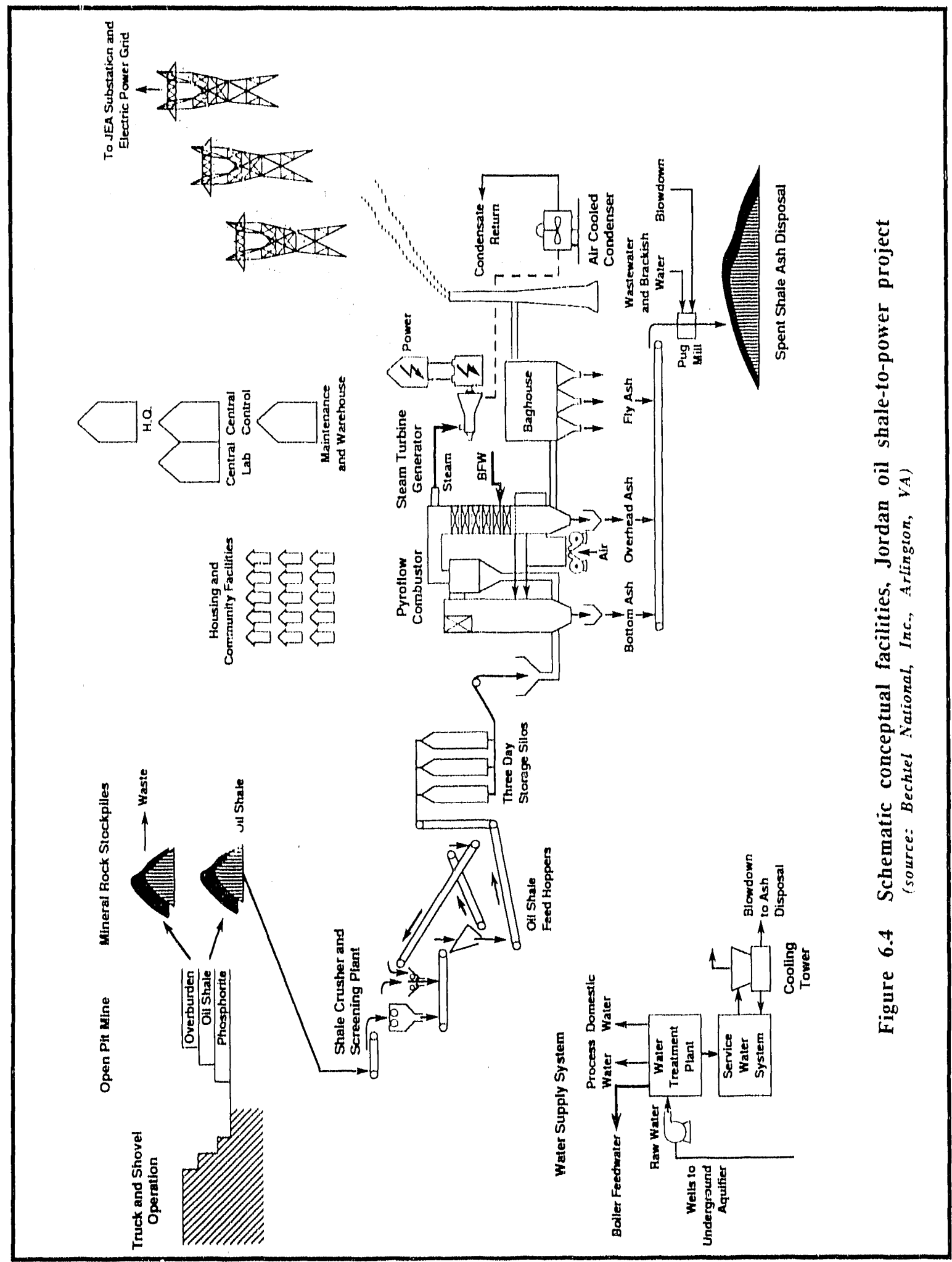




\section{ENVIRONMENTAL CONSIDERATIONS}

While the United States has considerable experience (dating back to the U.S. Department of Energy's synfuels program of the late 19\%()s) evaluating or roughly estlmating the projected impacts of oil shale technologies, what is known is gencrally related to experience only with retorting facilitics. In such facilities, liculd fuels, not power, are produced. The chemical reactions involved are much more complex than in the direct combustion processes proposed for the Sultani plant. Toxicity of a varicty of organic compounds, either in the emission stream or in the spent shale are the major environmental concerns. With the Sultani plant, the organics are nearly all combusted. Because projects in the U.S. have never produced at large calpacities and becaluse the mining operations supporting such projects have relatively low production rates and have been in operation only a relatively short time, there is little to learn from U.S, experience about the long-term elfects on miners exposed to shale oil dust.

The major issues of environmental concern in constructing and operating the proposed oil shale-to-power project at the Sultani site enter on fugitive dust, water availability, and potential groundwater contamination by heavy metals. The logistics of moving the enormous cjuantities of materials through the plant on a routine basis are staggering, as are the waste quantities of ash to be placed back in the ground in an environmentally responsible manner, Water availability in the desert location considered is of course, al ways a major concern.

\subsection{GENERAL ENVIRONMEN'TAL C'ONTEXT}

The eastern three quarters of Jordan are either rock or sand desert. Without irrigation, this land, the badia, can support a shifting pastoralist economy, but cannot support sustained agricultural cultivation and seulement. The Jordanian desert is part of the great Syrian Desert which covers large portions of Iray, Syria, Jordan, and Saudi Arabia. Being on the western periphery of this desert, the Jordanian desert tends to be slightly cooler and wetter. It is largely covered with a layer of flint and chert pebbles and sparse arid-land grasses.

'T'o the west of the desert, the land rises to merge into a natrow strip of steppe, forest, and arable land (known as the Western Highlands) before it is interrupted by the rugged and at times spectacular escarpment of the Rift Valley, Moving southwards from the northern part of Jordan, this severe depression is marked by Lake Tiberias, the Jordan River Valley, the Dead Sea, the desertic Wadli Araba, andel finally Agaba on the Red Sca's Ciulf of' Agaba. Some of the larger peaks east of the Dead S'a exceed 150) m, but most of the land lies at elevations of 50() $\mathrm{m} \mathrm{to} 100(0) \mathrm{m}$. The banks along the Dead Sea lie at $-4(0) \mathrm{m}$, the lowest point on land in the world.

The Sultani site is located in the eastern portion of the Karak Platcau where the western edge of the Eastern Desert lies within view of the Wesiern Highlands (see Figure 1,1). The land here is flall to rolling with some hill ridges. This land is sometimes termed the southern portion of the Mafray Steppe region.

The Sultani site is in the south-central catchment atea of Wadi Mujib, which covers an atrea of $460(0) \mathrm{km}^{2}$. 'The uper reaches of the wadlis (valleys) making up the Wadi Mujib are in semi-desert areats cast of the Desert Highway and cast of the Hijaz Railway. Here, and for the most part around the Sultani site, rainstorms are lovalized and floods are comparatively few. As a result, the wadis are not deeply incised as they are farther west, lower in the drainage basin. While rainfall can be as low as 5()$-10() \mathrm{mm} / \mathrm{y}$ in the high, semi-desert areas of the Wadli Mujib, the western portions receive $300 \mathrm{~mm} / \mathrm{y}$. The elevation at the Sultani site is around $822 \mathrm{~m}$ above sea level. There is a small, low desert dam on the Wadi Suliani, just south of the Sultani site. It is usually filled in the rainy season, but dries up toward the end of the stur, ier. Much of the flow behind the dam comes from effluent from processing phosphates at the Ea Abïtal Minc, about 1() $\mathrm{km}$ south of the Sultani site. 


\subsubsection{Climate}

Jordan's climate is commonly called Mediterranean, with ruin falling mostly during the winter months. A true Medlicrranean climate is to be found, however, only along the higher elevations east of the Rift Valley. 'The Sultani site in Central Jordan has a semi-arid Mediterrancan climate. Rainfall is concentrated into a cool winter scason; summers invariably have a pronounced drought. January is the coldest month and August the hottest. T'mperatures range form $7^{\circ} \mathrm{C}$ to $25^{\circ} \mathrm{C}$.

Climatic details for Qatranch, about $10 \mathrm{~km}$ north of the Sultani site and the closest source of representative data, are presented in Table 7.1.

Wind circulation follo'ws two patterns: the winter winds are mainly southwesterly at $25.35 \mathrm{~km} / \mathrm{h}$ and the summer winds are northwesterly at speeds of $15-30 \mathrm{~km} / \mathrm{h}$. Afterneon wind speods typically increase to 40 to 50 $\mathrm{km} / \mathrm{h}$. Abu-Ajamic't reports that the Sultant area can be alfected by dust storms brought on by winds blowing from the southeast. This occurs during the dry Khamasinic portod (a brief, regular oceurrence in the carly Splring).

Raln fall (about $110 \mathrm{~mm} / \mathrm{y}$ at Sultani Station) has apparently declined over the last 2000 years; this has concentrated the more "recent" nomadic pastoral activices (sheep, camels, and goats) in the more productive wadis in the western parts of the arid highlands, l.c., nearer the Sultani sitc, Rainfall occurs crrallically, with wide annual fluctuations. This makes water resource planning dirficult, because the impoundment of seasonal water flows in valleys is at the center of future water resource expatnsion hopes.

Snowfall oceurs in Decomber to March with the mean annual number of days being 4. The maximum number of days with snow is $14 \mathrm{~d} / \mathrm{y}$. The maximum snow depth is $40 \mathrm{~cm}$.

\subsubsection{Environmental Standards}

Jorlan has no comprehensive environmental standards regulating industrial development such as the proposed oil shale plant. In cooperation with the International Union for the Conservation of Natture (IUCN), AID is providing the GOJ with US\$ 150,0$)(0)$ in local currency and the IUCN with US\$38(0,0)(0) over the next two years to conduct a comprehensive analysis of the condition of the country's environmental systems and to prepare recommendations and standards that the GOJ might enact to protect environmental resources as the country undergoes further development.

In the absence of comprehensive standards to guide industrial development, the GOJ relies on the Department of Environment in the Ministry of Interior to perform monitoring and some enforcement of the more egregions allionts to the onvironment. Regulation is basically through negoliation, with the GOJ typically supporting the Department of Environment's decisions and actions, ${ }^{2}$ For major development, the Department of the Environment is looking to U.S. standards and World Bank guiddelines in the interim until the country adopts its own regulallory standards and procedures.

\subsubsection{Wildlife and Wildlife Resources}

Wildlife resources near the Sultani site are similar to those of extensive stretches of land along the Desert Highway. There are no plant or animal resources of significante that would likely be harmed by the

\footnotetext{
1 Abu-Ajumich, M., An Assiessment of the E/-Lajjun Oilshale Deposit, Natural Resources Authority, Hashemite Kingdom of Jordan, Amman, Jordan, February 1980.

2 'Tall, Sufyan A., Director of the Department of the Environment, persomal communication, April 14, 1988.
} 


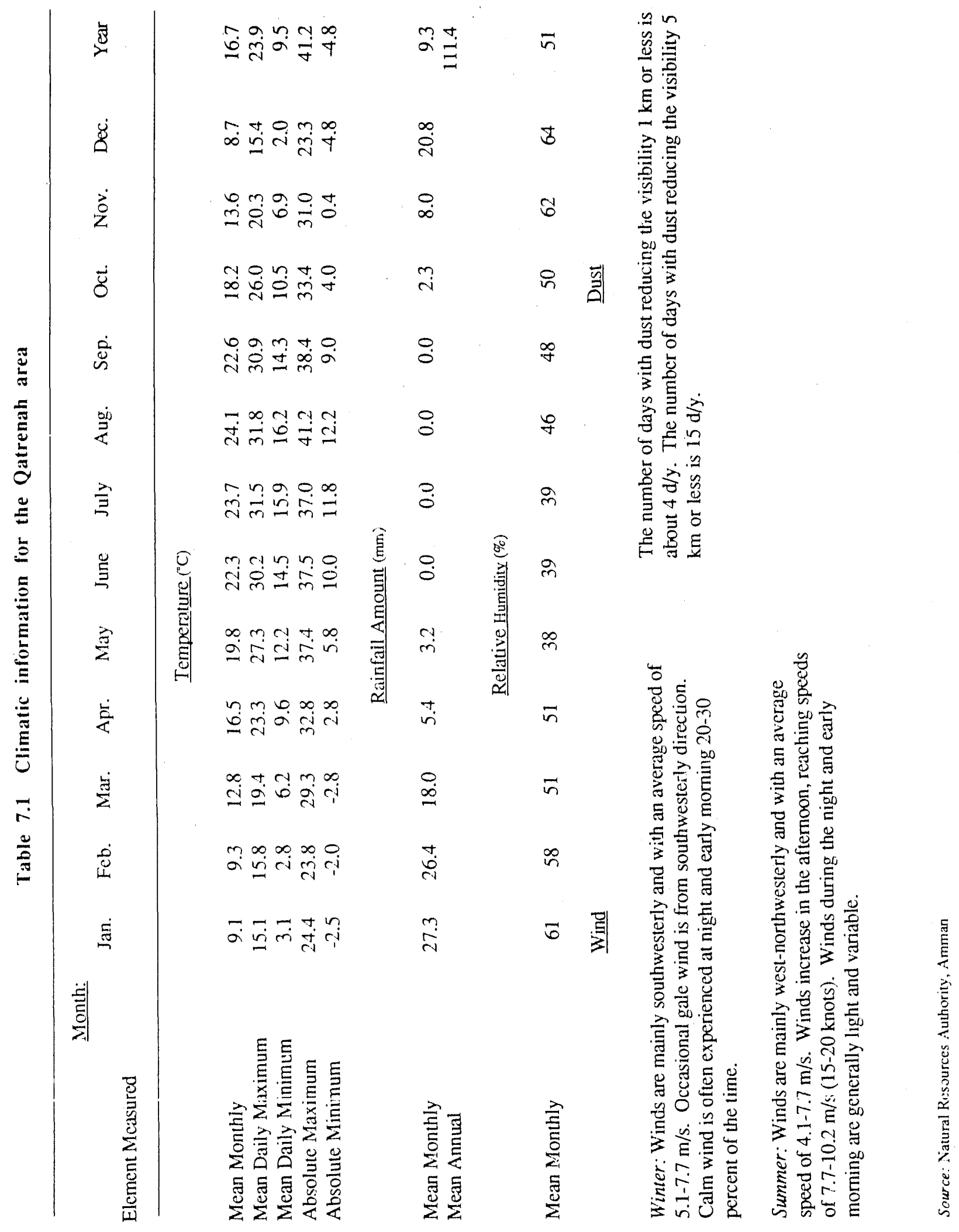


construction and operation of the proposed plant. A more thorough discussion of these resource management issues is given in Appendix A.

\subsubsection{Archaeology and Historic Sites}

Parts of Jordan have been continuously occupied since around 80000 B.C. Urban concentration did not appear until around the Bronze Age (3300-1200 B.C.). Evidence of human occupation in some places dates back to 100,000 B.C. The country's archaeological resources cover major sites from the Neolithic period, the Bronze Age, the Iron Age, the Hellenistic Age, the Nabatacan civilization, the Roman period, the Byzantine Empire, Early lslam, the era of the Crusades, and the Turkish occupation.

Much of Jordan's archaeological resourcus remain undiscovered, and if known, unexcavated in a major, scientific way. The area of the Sultani site is remote and expected to have few if any resources according to the Natural Resources Authority, which has responsibility for the lands and the mining activities there. If the proposed oil shale project advances to a Feasibility Assessment stage, responsible authorities with expertise in the relevant areas would need to be consulted about any resourees at Sultani that might be in need of special protection.

\subsection{POWER PLANT EMISSIONS}

The main gaseous emissions of concern with operation of the proposed power plant(s) are sulfur dioxide $\left(\mathrm{SO}_{2}\right)$, nitrogen oxides $\left(\mathrm{NO}_{\mathrm{x}}\right)$, and particulate matter. Dust, raw shale fines, and fly ash are the main romponents of the particulate emissions, and are discussed in Section 7.3.3. Dust emissions from the stacks are expected to be around $0.03 \mathrm{lbs} / \mathrm{Btu}$ heat input, within general international recommended maxima. The fly ash is the main concern regarding particulates.

A gaseous emission of increasing global concern is carbon dioxide $\left(\mathrm{CO}_{2}\right)$. The proposed project would emil more $\mathrm{CO}_{2}$ per unit of useful heat generated than would a coal or oil plant of similar electrical power output because of the carbonate composition of the shale in the fuel. The calcium carbonate rocks would calcine to lime under the heat of the combustion proeess. This reaction liberates $\mathrm{CO}_{2}$ and heat to the aumosphere as well as generating lime. This lime $(\mathrm{CaO})$ in turn reacts with the $\mathrm{SO}_{2}$ in the shale oil to form calcium sulfate, thereby limiting harmful $\mathrm{SO}_{2}$ emissions. Pyropower has not estimated the quantitics of $\mathrm{CO}_{2}$ that would be produced by the preposed oil shale project.

Emissions from the proposed power plant (any of the proposed sizes) should be within generally accepted international standards for $\mathrm{SO}_{2}$ (see below) without necding any downstream treatment. High combustion efficiencies from the vertical and lateral mixing inherent in the circulating fluidized bed combustion technology assure optimum carbon burnout (the test combustions in Finland showed over 98.5 percent combustion).

Shale of lower quality than the performance fuel specification may require supplemental fuel, such as petroleum coke or coal, for ignition or flame retention. Pyropower has deferred this aspect of the combustion to later studies. If such fucls are needed on a frequent basis, there, of course, would be $\mathrm{SO}_{2}$ and $\mathrm{NO}_{\mathrm{x}}$ cmission considerations different in magnitude from the shale-alone fucl. These issucs will have to be assessed in later studics.

The nature of Pyropower's circulating fluidized bed combustion lechnology would provide for a uniform temperature in the boiler, high heat transfer cocficients, and excellent mixing. The crushed oil shale would contact primary or fluidizing air (sec Section 5) in the lower combustion chamber. Here the shaie wouid be combusted in an oxygen-starved (reducing) environment while the calcium carbonate in the oil shale would be calcined to lime. Secondary air would be introduced at a higher level to provide the additional air required for complete combustion. The lime component (calcium carbonate) of the shate would react with the sulfur disxide resulting from oxidation of the sulfur in the fucl source to form calcium sulfate. 
Pyropower reports that combustion and sulfur retention occur at temperatures sufficient to provide maximum calcium utilization for $\mathrm{SO}_{2}$ removal yet low enough to minimize the formation of "thermal" $\mathrm{NO}_{x}$ (fixation of atmospheric nitrogen in the combustion air). The combustion tests in Finland demonstrated that over 90 percent of the fuel sulfur was absorbed by the inherent calcium in the oil shale. The use of staged combustion would inhibit the conversion of fuel-bound nitrogen to $\mathrm{NO}_{\mathrm{x}}$. High combustion efficiencies would be achieved due to the long residence time of the solids and to the weli-mixed isothermal environment.

The Ahlström Laboratory's tesi of the Jordanian oil shale sample fuel produced typical stack emissions for $\mathrm{SO}_{2}$ of below $20 \mathrm{ppm}$. This reading is equivalent $1056.8 \mathrm{mg} / \mathrm{m}^{3}$, and should be vicwed in reference to the World Bank's guideline (April 1984) for ambient air quality: a maximum arithmetic mean inside and outside the plant of $100 \mathrm{mg} / \mathrm{m}^{3}$, the U.S. Environmental Protection Agency's maximum of $80 \mathrm{mg} / \mathrm{m}^{3}$, and the World Health Orgarization's level at which health effects may begin to be meastired of 40 to $60 \mathrm{mg} / \mathrm{m}^{3}$. With the localion of the proposed project, the generally excellent daily wind ventilation of the site, and with the combustion technology and fuel sources proposed, there appears little to be concerned about regarding the plant's $\mathrm{SO}_{2}$ emissions. Of course, more accurate estimates of ambient projected air quality would require use of an air dispersion model, an intention of the Bechtel Group if this proposed project progresses to a full enginecring feasibility analysis. U.S. industrial facilities are gencrally required to remove about 95 percent of the $\mathrm{SO}_{2}$ emittul. While the Pyropower boiler is intended to achieve about $9\left(0\right.$ pereent $\mathrm{SO}_{2}$ removal, this should be most adequate given the assumption (no data) that the Sultanı site hass low background SOn concentrations.

The Ahlstrom tests also reported $\mathrm{NO}_{\mathrm{x}}$ cmissions of $6($ ) to 120) ppm. This corresponds to readings of 115 to 229 $\mathrm{mg} / \mathrm{m}^{3}$. These are stack emissions, and in the well-ventilated conditions of the Sultani site should be dispersed to $\mathrm{NO}_{\mathrm{x}}$ concentrations easily within the World Bank guideline (November 1982) for ambient air concentration of $\mathrm{NO}_{\mathrm{x}}$ : annual arithmetic mean of $100 \mathrm{mg} / \mathrm{m}^{3}$. Again, air dispersion modeling would be a requisite action in a full feasibility assessment. The U.S. National Clean Air Act and National Ambient Air Quality Standards have the same annual arithmetic mean as the World Bank guideline. Interpretation of these readings is difficult without more background data on the Sultani site and use of a dispersion model to augment these data. Candidate worst case conditions for air dispersal modelin would be several days of atmospheric stagnation, winds from the south in the Spring, or moderale wind conditions in which a stable polluted layer spreads uniformly and causes visibility reduction over a large area. The Bechtel Group reports that $\mathrm{NO}_{\mathrm{x}}$ from the Pyropower boiler is expected to be $0.6 \mathrm{lbs} /$ million Bu boiler heat input, typical for U.S. industrial plant $\mathrm{NO}_{\mathrm{x}}$ emissions.

The environmentad impacts of plant construction are expected to be normal for the type and size of facility proposed. The lack of significant seasonal rains means that construction can procecd year-round without specific stratagems needed to control for erosion and runoff beyond those undertaken in normal desert construction (flash flooding concern).

Secondary environmental effects of plant construction and operation are largely factored into the community and other workforce infrastructure design plans put forth by the Bechicl Group. Sanitary wastes in domestic and service waste streams would need to be kept. separate and treated by using commercially available biological tratment units.

\subsubsection{Dust Control}

Jordan's air quality outside of the major cities is quite good, benefiting from consistent daily winds, little persistent cloud cover, a variable (but non-confining) tonouraphy that promotes daily air movement, and a warm, sunny climate. Overnight air inversions are occasionally observed in the valleys and uplands, but are generally broken up by daily wind patterns within 6 to 8 hours. The Bechtel Group's plans call for establishment of bascline studies of site-specific air quality to monitor and model fugitive dust (and other) 
cmissions. Such information and models would help develop necessary mitigation practices to assure the protection of the local air quality and worker and local residents' heatth.

World Bank guidelines for dust concentration levels consider two conlexts: one for the workplace and one for the cnvironment beyond the plant boundarics. Dust concentration levels for inside the plant/mine complex are threshold limit values (TLV) for workers exposed cight hours a day, and $40 \mathrm{~h} / \mathrm{weck}$. The plant/mine complex would need to be designed and operaled to provide actual dust levels well below the TLV because of the unknown toxicity of the fly ash.

World Bank environmentally acceptable levels of dust emissions vis-à-vis background dust levels are: annual geometric mean less than $70 \mathrm{mg} / \mathrm{m}^{3}$ above local background level and maximum 24 hourly concentration less than $5 \times$ annual geometric mean of local background dust level. The U.S. National Clean Air Act and the National Ambient Air Quality Standards cail for a maximum annual arithmetic mean of $75 \mathrm{mg} / \mathrm{m}^{3}$ and a maximum of $260 \mathrm{mg} / \mathrm{m}^{3}$ in any $24-\mathrm{h}$ period. At this point there are no background dust data for the Sultani sitc.

\subsection{OVERBURDEN AND ASH DISPOSAL SYSTEM}

Combustion of Jordanian oil shale would produce substantial volumes of overburden and ash requiring disposal. At peak, operation of the 4()()-MW plant would gencrate approximately $1(0)(0)$ tonnes per hour of wetted shale ash for disposal.

To provide a basis for predicting the environmental impacts of the disposed solid wastes, samples of the raw shale and ash from the test burn were shipped to Oak Ridge National Laboratory and analyzed.

\subsubsection{Analyses of Shale and Ash}

The material available for analysis was shipped from Finland after the test burn performed by Pyropower, Inc. The material available for analysis consisted of about $250 \mathrm{~kg}$ of raw shale (shipped in one 55 -gal drum), about $9000 \mathrm{~kg}$ of bottom ash (shipped in 4655 -gal (Irums), and about 6000$) \mathrm{kg}$ of fly ash (shipped in 16 large plastic "Big Bags"). Ash was available from cach of the eight test runs; most of the analyses focused on ash from test Run \#1, the test run with firing conditions that most closely matched the proposed conditions for the proposed combustor in Jordan. The additional ash was set aside for later tests of its resource recovery petential.

\subsubsection{Densily}

Bulk density is a physical property of ash that inlluences both the area that would be required for disposal of the ash and its potential for by-product utilization. Measurement of bulk density was done simply by weighing a given volume of material. No effort was made to compact the ash or shale or determine its absolute density (independent of interstitial space between particles). The bulk density of the raw shale was $1.23 \mathrm{~g} / \mathrm{mL}$, and bulk densities of fly ash and bottom ash varied from about $0.97101 .05 \mathrm{~g} / \mathrm{mL}$, all within 5 percent of $1.0 \mathrm{~g} / \mathrm{mL}$, the density of water. Bulk density data are presented in Table 7.2 and compared in Figure 7.1. 


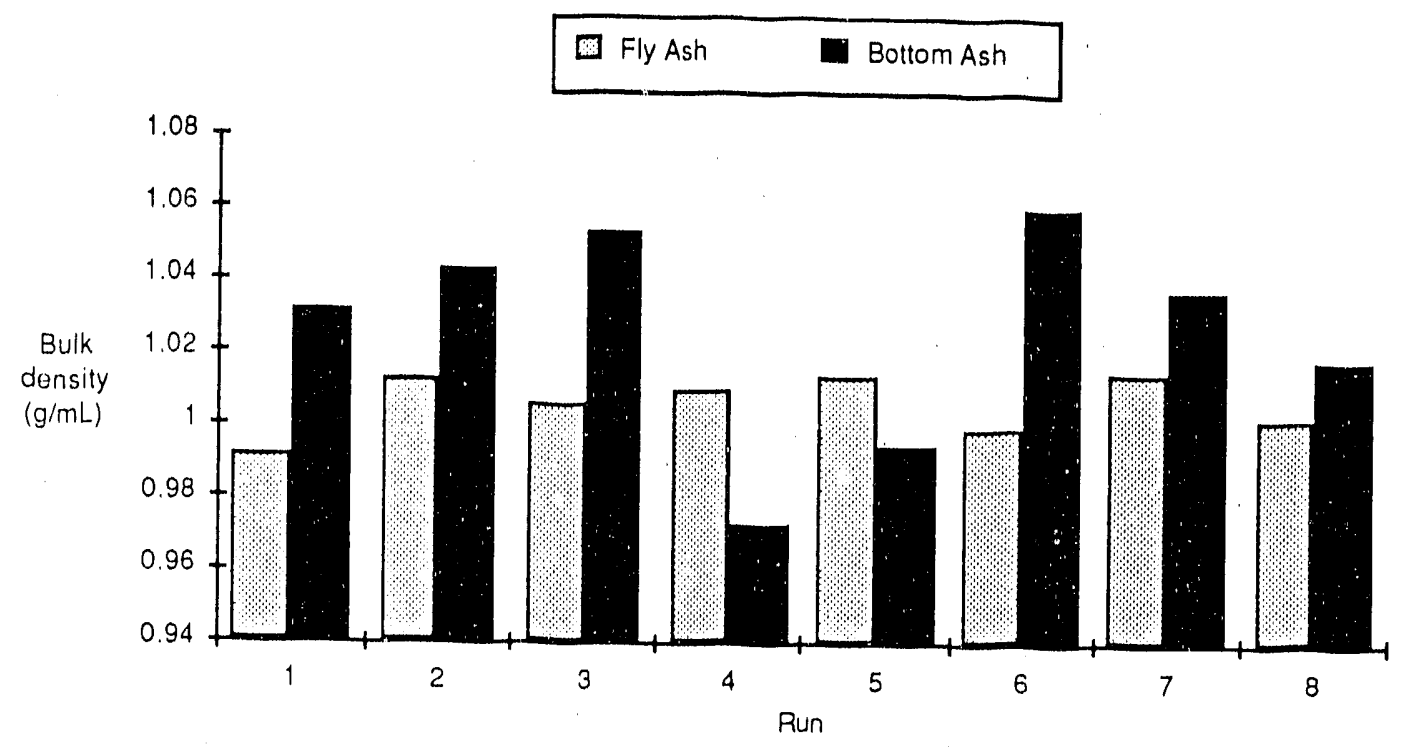

Figure 7.1 Bulk density of ash. (bulk density of raw shale was $1.23 \mathrm{~g} / \mathrm{mL}$ )

Table 7.2 Bulk density of shale and ash from eight test runs $(\mathrm{g} / \mathrm{mL})$

\begin{tabular}{ccc}
\hline Run & Fly Ash & Bollom Ashl \\
\hline 1 & 0.9915 & 1.0313 \\
2 & 1.0131 & 1.0432 \\
3 & $1.0(056$ & 1.0532 \\
4 & 1.0096 & 0.9727 \\
5 & 1.0134 & 0.9945 \\
6 & 0.9993 & 1.0599 \\
7 & 1.0143 & 1.0372 \\
8 & 1.0026 & 1.0187 \\
\hline
\end{tabular}

Although one would expect bottom ash to have a greater density than fly ash, the smaller and more uniform particle size of fly ash (Sect. 7.3.1.2) allows fly ash to compact to a greater extent, thus producing slightly higher bulk densities in some cases (Runs \#4 and \#5). The variation in density of ash is much less important than the fact that the ash is at least 18 percent less dense than the crushed raw shale.

\subsubsection{Distribution of particle size}

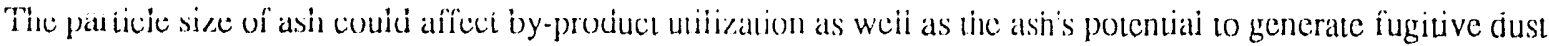
from the disposal site or by-product processing facility. Distribution of particle size was determined by using the Microtrac automated particle size sampler (for fly ash) and by using sicve screens for the bottom ash and raw 
shale. The distributions of particle size for fly ash, bothom ash, and crushed raw shale are shown in Figures 7.2 and 7.3 .

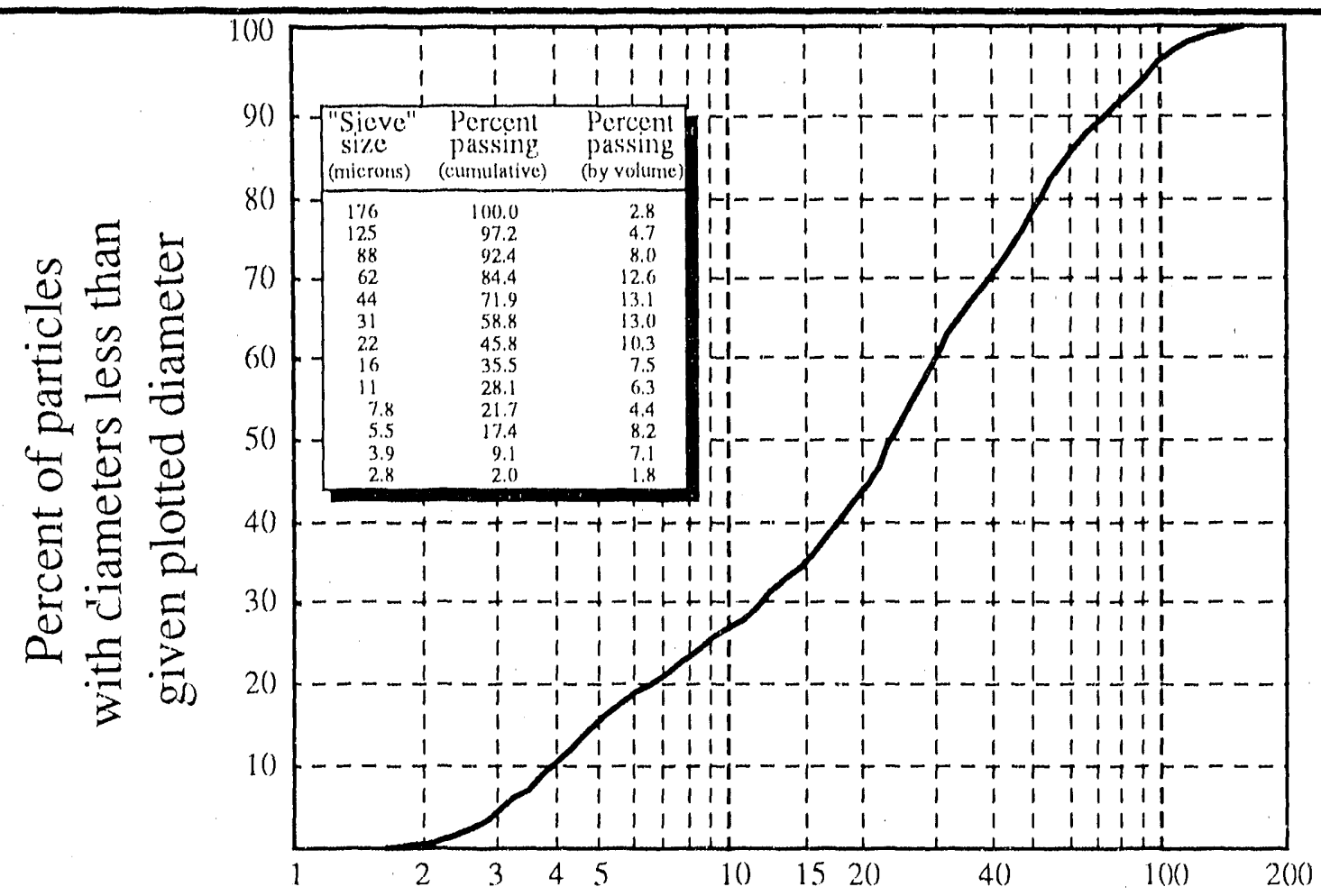

Figure 7.2 Particle size distribution of ash and crushed shate from test burn of Jordanian oil slaale. (Semilengarithmic graph indicates the per cent ash by weight, $Y$ axis, that is less than the diameter stewen-in $\mu-0$ on the $X$-axis)

The lower size limits for dust particles are in the transilion anc 6 larger gas molecules (about $1 \mu$ or less) and as such are likely to be exhaled as readily as they are inlailed, depending on particle shape and specifie gravity. The upper limit for particulate size is around $5(0) \mu$, or al about the size where gravily will rapidly remove a particle from the air such that is poses no hatard to respiration.

\subsubsection{Proximatc and ultimate analyses}

Proximate, ultimate, and elemental analyses were peylumed on crushed raw shale and fly ash and bottom ash from Run \#1, Table 7.3 presents the results from these lests.

7.3.1.4 Carbon and sulfur analyses

Data on total carbon and sulfur content of the shale and atsly are presented in Table 7.4.

\subsubsection{Leaching characteristics of ash and shale}

To determine the potential for contamination of gromedwalcr, the extraction procedure for toxicily (tep-1 ox) was performed. This test is routinely used to determine if w'aste materials are classificd as "hazardous" under the U.S. Resource Conservation and Recovery Act (RCRA) because of the toxicity of the leachate generated from the waste. To perform the EP-Tox, the ash or shale wals ground using a mortar and pestle so that all particles 


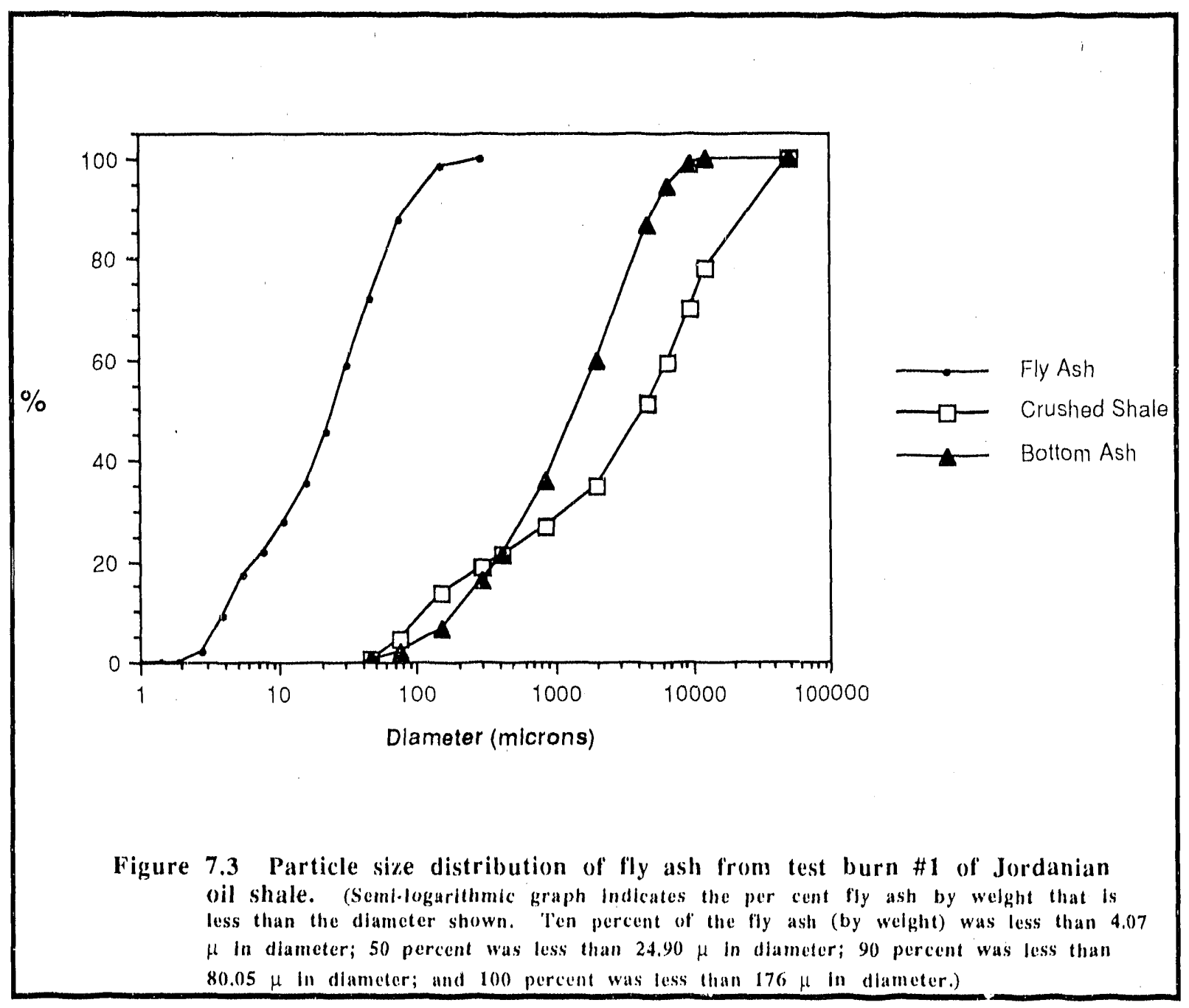

would pass a $9.5 \mathrm{~mm}$ sieve. The ground material is placed in a llask of distilled water and placed on a shaker. The contents of the flask are filtered to remove the solids, and the liquid clutriate is analyzed to determine what constituents of the waste have dissolved in the water. The elutriate for the ash and shale were analyzed for trace clements and semi-volatile organic compounds. A wasie is considered hazardous because of its toxicity if the concentration of any constituent in the elutriate excecds the Drinking Water Standard (set by the U.S. EPA) by a factor of 100. Data from the EP-Tox are presented in Table 7.5.

\subsubsection{Potential Water Quality Impacts}

Water quality impacts from the disposal of ash and overburden could involve the leaching of soluble trace elements into groundwater and introduction of fugitive particulate matter into ephemeral watercourses or reservoirs. The extent to which these potential impacts would be expected to occur is discussed below. The results of the EP-Tox leaching test (Sect 7.3.1.5 and Table 7.5) indicate that the fly ash from combustion of the Jordanian oil shale has a greater potential for leaching soluble trace elements than does the bottom ash or raw shale. The concentrations of chromium and selenium in the leachate from fly ash were about 10 times 
Table 7.3 Results of proximate, ultimate, and elemental analyses

\begin{tabular}{|c|c|c|c|}
\hline & Crushed shale & Fly ash & Bottom ash \\
\hline \multicolumn{4}{|l|}{ Proximate analysis } \\
\hline Moisture (\%) & 1.64 & 0.16 & 0.25 \\
\hline Volatile matter $(\%)$ & 35.2 & 3.37 & 5.12 \\
\hline Fixed carbon (\%) & $<1.0$ & $<1.0$ & $<1.0$ \\
\hline Ash $(\%)$ & 67.03 & 98.71 & 96.31 \\
\hline \multicolumn{4}{|l|}{ Ulimate analysis } \\
\hline Carbon $(\%)$ & 18.0 & $<1.0$ & $<1.0$ \\
\hline Hydrogen (\%) & 1.52 & $<1.0$ & $<1.0$ \\
\hline Nitrogen (\%) & $<1.0$ & $<1.0$ & $<1.0$ \\
\hline Sulfur $(\%)$ & $3 .(01$ & 4.94 & 3.49 \\
\hline Oxygen (\%) & 26.4 & 28.7 & 28.9 \\
\hline Btu/lb (dry wl) & 2564 & a & $\mathrm{a}$ \\
\hline $\mathrm{kJ} / \mathrm{kg}$ & 5963 & a & a \\
\hline \multicolumn{4}{|l|}{ Elements, $\left(\mathrm{ppm}^{\mathrm{b}}\right)$} \\
\hline $\mathrm{Ag}$ & $<4$ & 4 & 5 \\
\hline $\mathrm{Al}$ & 11000 & 17000 & 9380 \\
\hline As & $<0()$ & $<60$ & $<60$ \\
\hline B & 24 & 31 & 20 \\
\hline $\mathrm{Ba}$ & 80 & 128 & 320 \\
\hline $\mathrm{Be}$ & 0.6 & 1.1 & 0.5 \\
\hline $\mathrm{Cd}$ & 182 & 156 & 153 \\
\hline Co & 4 & 5 & 3 \\
\hline $\mathrm{Cr}$ & 451 & 535 & 342 \\
\hline $\mathrm{Cu}$ & 136 & 162 & 122 \\
\hline $\mathrm{Fe}$ & 6160 & $9(180$ & 4950 \\
\hline $\mathrm{Ga}$ & $<40$ & $<4()$ & $<4()$ \\
\hline $\mathrm{K}$ & $37(0)$ & 5300 & 3200 \\
\hline $\mathrm{Li}$ & 29.5 & 32.5 & 29.6 \\
\hline $\mathrm{Mg}$ & 5470) & 5550 & 3960 \\
\hline $\mathrm{Mn}$ & 38.7 & 56.9 & 51.9 \\
\hline Mo & 244 & 275 & 177 \\
\hline $\mathrm{Na}$ & 282() & 3790 & 2550 \\
\hline $\mathrm{Nb}$ & 40) & 43 & 39 \\
\hline $\mathrm{Ni}$ & 240 & 295 & 183 \\
\hline$P$ & $180(0)$ & $20(0)(0)$ & $160(0)$ \\
\hline $\mathrm{Pb}$ & $<20$ & $<20$ & $<20$ \\
\hline Sc & 3.6 & 5 & 3.1 \\
\hline $\mathrm{Sr}$ & 99.4 & 1110 & 917 \\
\hline V & 4.38 & 541 & 341 \\
\hline Y & 23.1 & 28.7 & 20.8 \\
\hline $\mathrm{Zn}$ & 1630 & 1730 & 1210) \\
\hline $\mathrm{Zr}$ & 25 & 31 & 21 \\
\hline
\end{tabular}

greater than levels that leached from bottom ash. The tendency of fly ash to leach trace elements is thought to be associated with the smal! particle sion of fly ast and also possibly the greater solubility of trace elements that have undergone more extreme heating, complete separation from the organic matrix of the fuel, and subsequent adsorption onto the surface of fly ash particles. In an exception to the paltern of fly ash having the greatest 
tendency to leach trace elements, the raw shale produced almost 10) times the concentration of cadmium leached from fly ash or bottom ash. Because semivolatile organic compounds were not found in the ash leachate, no contamination of groundwater by organic compounds would be expected from ash disposal.

Table 7.4 Concentration of carbon and sulfur in raw shale and ash from Run \# 1

\begin{tabular}{|c|c|c|c|}
\hline Constituent & Oil Shale & Fly Ash & Bollom Ash \\
\hline Sulfur (\%) & 3.73 & 6.04 & 3.02 \\
\hline \multicolumn{4}{|l|}{ Total carbon (\%) } \\
\hline Replicate 1 & 14.() & 0.46 & 1.00 \\
\hline Replicate 2 & 17.2 & $(0.47$ & 1.04 \\
\hline Replicate 3 & 18.2 & NAI & 1.75 \\
\hline Average & 16.5 & 0.5 & 1.3 \\
\hline
\end{tabular}

Tnot available

Table 7.5 Concentration of constituents in leachate from EP-Tox test on raw shale and ash from Run \#1

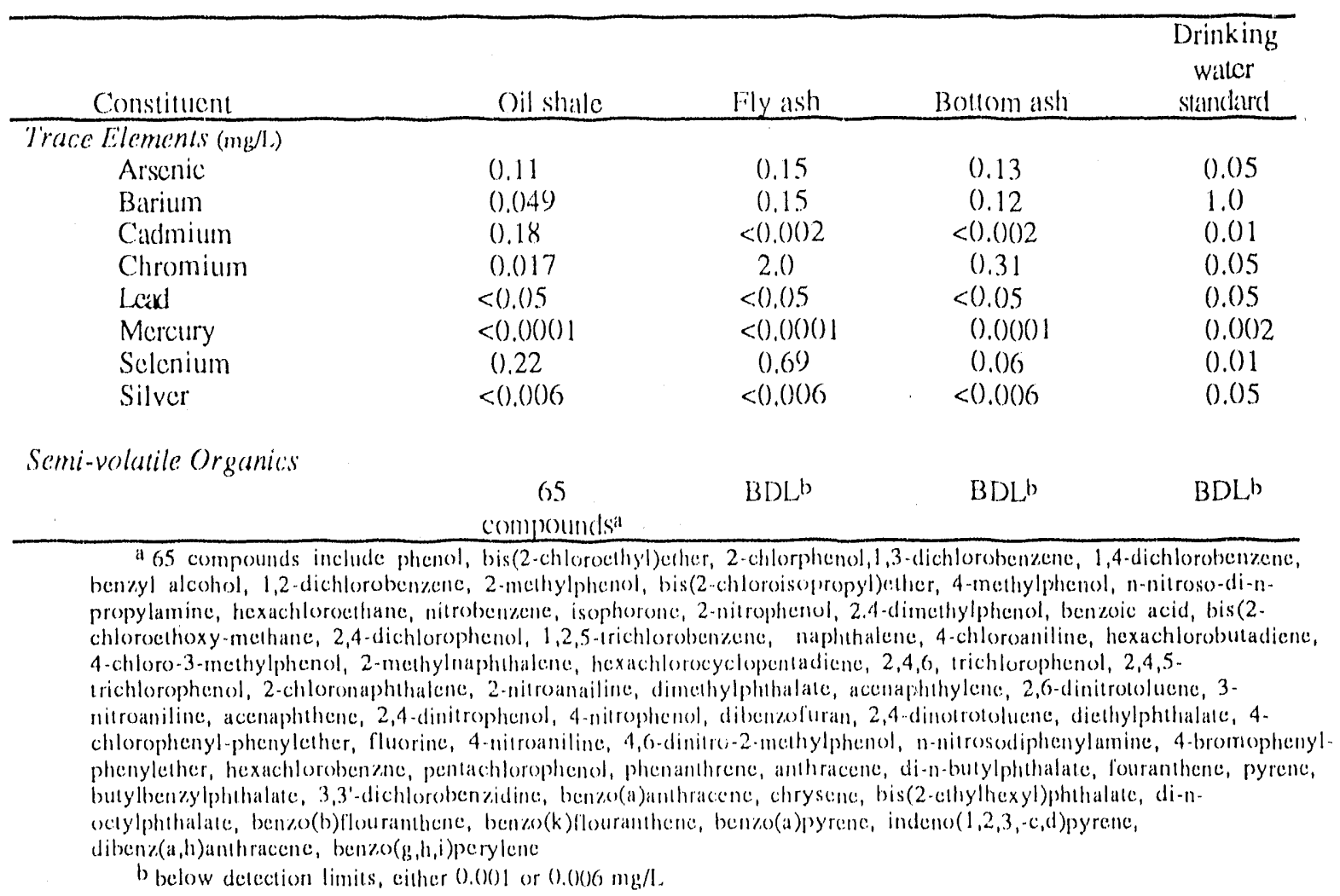


Ash disposal from the proposed facility appears to pose some risk of groundwater contamination. After the first 3 years of mine development, ash would be disposed of by placement in the pit from which the oil shale had becn removed. This pit is expected to be up to 100)-105 $\mathrm{m}$ decp (a mean of $69 \mathrm{~m}$ of overburden and a mean of $32 \mathrm{~m}$ of shale). Because the A2-B7 aquifer (Sect. 7.4) can be found at deptlis of 80 $1095 \mathrm{~m}$ in the Sultani area, ash placed in the bottom of the mine pit could be below the water table and subject to leaching by groundwater. Ash placed above the water table would also be subject to leaching by precipitation, although such leaching would be expected to be less extreme because of the very limited precipilation.

Based on the results of the EP.Tox leaching test, leaching of fly ast could result in concentrations of chromium, selenium, and perhaps arsenic that exeed the U. S. drinking water standards. Some dilution of these elevated levels could be expected as ground wate: migrated away from the disposal site. Noncheless, disposal of ash below or near the water table could degrade groundwaler cluality locally to the extent that water might become unsuitable for use as a potable water supply. A possible miligation would be to place overburden or bottom ash in the bottom of the mine pit, while placing fly ash, with its greater tendency to leach trace elements, nearer to the surface. The low levels of rainfall in the area make the overall hazard to potable water supplies quite minimal, but systematic and periodic monitoring by groundwater instrumentation would be necessary; such metering is anticipated by the Bechtel Group in their general environmental baseline and long-term monitoring for the proposed project.

The reactability of the spent shale with any constituents of the overburden is unknown.

\subsubsection{Potential Air Quality Impacts}

Transport and disposal of ash maly result in the release of ligitive particulate matter. Operating plans call for ash from the combustion unit to be wetted (to a 20 percent water content by weight, using boiler blow-down and other plant waste water streams) and trucked to the site of disposal or by-product utilization. The wetung is to minimize the generation of dust during transportation to the mine and disposal. Haul roads and pie roads are to be sprayed with water on a periodic basis to sup? ress dust generation. The ash is to be layered with overburden in the disposal plan in order to minimize wind crosion and to reduce the potential for leaching. The Bechtel Group's plans call for the ash to be disposed of in a surface landlill for the first three years of operation until the mining pit was sufficiently developed to aceept waste ash.

The Bechtel Group made no assessment of exhaust emissions from diesel oil-fieled mining eguipment and haul trucks. Because of the areal size of the pit, these are not considered to be a health problem ce spite the enclosed and decp nalure of the pit.

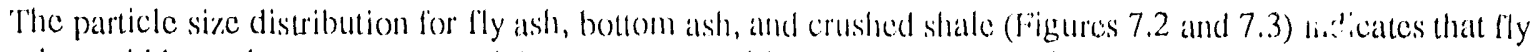
ash would have the greatest potential to generalle lugitive particulate emissions. Particles less than 4.5 microns $(\mu)$ in diameter constituted less than 1 percent by weigh ol both the bottom ash and the crushed shale, but about 7.5 pereent of the fly ash. Smaller particles are much more likely than larger particles to generate fugitive dust because they can be suspended by wind. About 25 percent of the fly ash consists of particles less than $10 \mu$ in diameter, and are considered to pose a greater risk to humbun heallh than targer particles becaluse of the hazards of inhaling and retaining small particles (see Appendix C).

The rate of fugitive fly ash emissions from the ash disposal operalion would depend on the movisture content of the fly ash, wind velocity at the surface, the roughness of the surfice, and the presence of obstactes such as rocks or vegetation. At present, insufficient information regarding ash handling and disposal is available to estimate actual emission rates. The guantities of fly ash expected to be produced by the combustion process relatuve to bottom ash are in the ratio of 6() to 70 percent lly ash 1030 10 40 percent bottom ash (by weight).

Assuming the fly ash to te inert or only a "nuisance dust," Wortic Bank thresinoid limit values for an 8 - -1 workday are $5 \mathrm{mg} / \mathrm{m}^{3}$ for respirable dust (as defined by the British Medical Rescarch Council criteria, and as 
sampled by a device producing equivalent results) and $1.5 \mathrm{mg} / \mathrm{m}^{3}$ for tolal dust. According to EPA guidelines, adverse human health effects begin when ambient levels of dust execed $80 \mathrm{\mu g} / \mathrm{m}^{3}$. Current guldelines call for 75 $\mu \mathrm{g} / \mathrm{m}^{3}$ as the annual geometric mean for a project background limit and $260 \mathrm{\mu g} / \mathrm{ml}^{3}$ as the maximum allowable 24-h concentration, no more than once per year. The World Bank has used these as inputs to its own guidelines, but is hesitant to be more stringent beyond these because variations due to the physical or ehemical characteristics of dusts, climates, locations, and other factors make universal guidelines somewhat difficult to meaning fully implement.

\section{Stack Emissions:}

When background levels of dust are high, dust emissions from the stacks should not be greater than 100$) \mathrm{mg} / \mathrm{m}^{3}$.

Ambient Levels:

$\begin{array}{ll}\text { Annual geometric mean } & 10() \mu \mathrm{g} / \mathrm{m}^{3} \\ \text { Ma:: }: \text { mum 24-h concentration } & 5(0) \mu \mathrm{g} / \mathrm{m}^{3}\end{array}$

The main air pollutant from the proposed project will be ligitive dust. Pyropower and the Bechtel Group's use of eyclones in the combustion process should help minimize ash dispersal there. The Bechtel Group calls for the use of dust collectors at the oil shale process crushing plant, in both the storage and processing areas. Single cyclones remove about 9() pereent of the larger particles, but less than 5() pereent of those smaller than about $10 \mu$. Their removal efficiencies could be increased by using second-stage cleaning in scrubbers, filters, or precipitators. This issue should be investigated in later design stages in order to protect worker health and the gencral environment.

Open-pit mining will, of course, generate considerable dust. Because of the decp nature of the pit, however, much dust from excavation will be contained below ground level, in the pit and away from prevailing winds. The extensive use of trucks will necessitate regular waler spraying on roads to suppress fugitive dust. Dust emissions at the crusher should be controllable by dry cyclones: Water spraying is about 80 pereent effective fior particles larger than $5 \mu$, so this technique should be effective at the Sultani project.

\subsubsection{Potential Land Use Impacts}

The Bechtel Group estimates that the waste from the mine supporting the 4()()-MW project would be in excess of 25 million bank (expanded, or excavalted, volume) $\mathrm{m}^{3}$ and that the spent shale equivalent would be more than 6 million bank $\mathrm{m}^{3}$.

Shale consumption by four 1()()-MW units is estimated to be 22,680) tomnes/d, or 7.78 million tonnes/y, based on operating 35() days/y (a higher production figure than necessary 10 support a 4())-MW plant operating at a 75 percent capacity factor). This production rate would also produce 6.127 million tomes/y of welted ash. Given the shale's specific gravity of $1.8 \mathrm{~g} / \mathrm{ce}$ (in place), the average $69 \mathrm{~m}$ thickness of the overburden, average $32 \mathrm{~m}$ thickness of the oil shale seam, a 95 pereent shale recovery rable, and a 20 percent exeess overburden removal rate for the tiering needed in the pit wall, it is calculaled that $0.17 \mathrm{~km}^{2} / \mathrm{yr}^{\mathrm{r}}$ would be disturbed for mining operations. It is assumed that the overburden has the same specific gravity as the shale and that its volume expands by 40 pereent (the Bechtel Group's plans assume a 30 percent expansion fictor) upon renoval; if overburden is piled to a depth of $10 \mathrm{~m}$, the area required for overburden disposal during the first three years of o cration is estimated to be $4.0 \mathrm{~km}^{2}$. Approximately 7.4 million bank $\mathrm{m}^{3}$ of overburclen is to be excavaled and hauled to the oul-of-pit waste pile.

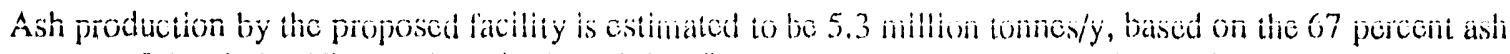
content of the shale. The test burn indicated that lly ash and bottom ash would be produced in a ratio of 53:47. 
Based on the bulk densities measured for fly ash and bottom ash from Test Run \#1 (Table 7.4.1), annual production of ash would be $2.8 \mathrm{million} \mathrm{m}^{3} / \mathrm{yr}$ of lly ash and $2.5 \mathrm{million} \mathrm{m}^{3} / \mathrm{yr}$ of bottom ash. During the first three years of operation, ash disposal would be in a surface landritl, the out-of-plt waste pille; if ash were piled to a depth of $10 \mathrm{~m}, 1,6 \mathrm{~km}^{2}$ of land would be recpuired.

\subsubsection{Overburden Handling}

7.3.5.1 Out-of-Pit Surface waste disposal and land reclamation

Relevant World Bank guidetines for land reclamation include:

Surface mine reclamalion shall be performed in such a matumer that the lands are retumbed to conditions capable of supporting prior land uses or uses that are ocgual to or better than prior land ase. ... llighwalls and spoil piles must be eliminnted and the approximate original contour restored. All surface areas must be stabilized and protected in order to control slides, crosion, subsidence, and accompanying water pollution. Water impoundmonts, retention facilitles, dams, or sectling ponds shall bo adectuate for intended land use. These facillites cannot produce significant adverse effects to adjacent water resources. Operators must use best practicable commercially avallablo techinoloey to minimias, control, or prevent disturbances to surface or underground water cuality, quantity, or flow. Mining wastes and rubbish must be properly disposed of so as to minimize, control, or prevent water pollution.... It is imponant that land reclamation be started as secon as possible and at least three years afier the opening of the mine. The Bank Mission should recelve ooncrete and detailed proposals on the reckamation program and on the means necessary to achieve it. ${ }^{3}$

The Bechtel Group's plans call for employing reclamation procedures that would "minimize adverse impacts during mining and (that would| restore all affected lands to their pre-mining land use." While the emphasis is appropriately on controlling wind and water erosion, more than land stabilization is required by the World Bank. The Bank calls for climination of all high walls and spoils piles. The Bechtel (iroup's plans do not at this prefeasibility stage contain details about whether the exciavalion pit would be completely backfilled upon completion of the mining operation or whether the mining area would be pe anenlly fenced (with warning signs posted) to keep people forever away from the pit's highwall. They also do not address the issur of whether or not the pil's highwalls would be graded to a lower, more stable slope. There have been deaths of Jordanian youths due to suffocation under shilting spoils piles from abandened phosphate mines and from drownings in abandoned phosphate pits. While the Becheel Groupts plans call for revegetation, they do not at this cursory analytical stage call for any test plots to determine which species would do best and what fertilization/irrigation regimes (if any) would work best on the reclaimed lands. The land's prior use was overgrazed open pasture. The Bechel plans do not have details about what procedures would be empleyed to prevent overgrazing while new vegetation is being established.

The ash alone is an undesirable plant growth medium hecause of its small particle size (texture), which cncourages erosion, compaction, and comentalion (in as few as 3 dias alter being moistened) which causes poor root penetration and low permeability. The ash has a high alkalinity and high quantites of dissolved salts, including elements that may be toxic to plant growth or at a minimum that may inhibit water and nutrient uptake. The Bechtel Group's plans call for revegelation using the original topsoil; this is appropriate and probally essential. The vegelative cover will "lake" most quickly and persist longer with topsoil than it wo'ld with overburden or ash materials. The rectaimed areals should be fenced and protected by other proper maintenance and monitoring activities to ensure stability.

In gencral, the Bechtel Group's plans at this stage of analysis call for appropriate consideration to reclamation needs. The open pit at the end of the mining operalion would be the chicl rectamation concern. The out-of-pit waste disposal pile would be enginecred ior stability and its surfaces revegetated. No mention is made of the

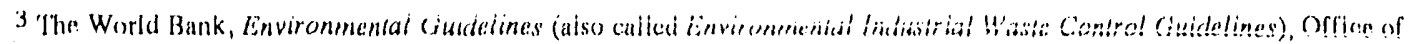
linvironmental Affairs, The World Bank, Washington, D.C., 1984.
} 
acsthete compatibillty of the flinal lorm of the pile with the surrounding landiorms. In a site as highly vistble as this (along the Descrt Highway), this issue needs consideration. No mention is made of the engineering precautions taken for assuring stability of all disturbed areas in the event of major flash floods. Litule mention is made of the need to integrate the flinal landlorms into existhy surfice water drainge patterns. This, too, could be important In a flash llood.

\subsubsection{Erosion and sedimentation control}

Consistent with the World Bank's guidelines, the Bechel Ciroup's plans cull lor water ditehes to be dug on the surface around the excavation pit area and the waste disposal area to provent indigenous surface and groundwaters from being contaminated with rainwater runoll from the disturbed areas and to prevent these waters from entering the disturbed areas, Sedimentation ponds are lo be constructed to collect water from disturbed areas in order to achieve zero discharge. After these ponds are built, the topseil in the put area, haul roads, and waste disposal areas would be removed and stored for use in later land reclanation. Watcer runofl lrom within the pit would be collected in a sump and would be used for wenting the haul roads.

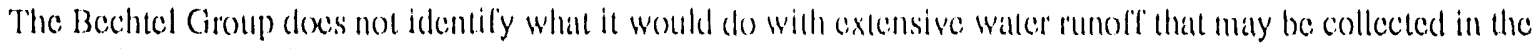
excavation pit, as with that from a flash flood or extensive and unusual seasomal rains. Nor do the plans identify how secpange from intererpting the waller table in the excalvition pit would be remedied or what effect such secpage could have on litial plant operations.

\subsubsection{Resource Recovery}

The use of the waste ashl for cement manuficture or as an anendment to oblher construction materials has not been studied in depth at this time. The exace chemistry and physical properties of the ash would be critical in making a feasibility determination. Because the fechnology and fluel wgether are new, there is no U.S. experience that would be directly applicable, In a lull feasibility assessment, this can be examined through (1) Inarket studes in Jordan and (2) enginecring and durability studies with the ash sent lo Oak Ridge National Laboratory from the test burn. Preliminary assessment of a matket for the valst guantities of ash suggest that there is now no demand for the extra ash in Jordan or in nearby internalional markess. This siluation could change by the mid-199() or later'. Because of the lack of market demand and the prefeasibility mature of this current study, no further exploration of the polential use of the fly ash an a resource was made.

\subsubsection{Vulnerability to Sicismic Activity}

No analysis of the vulnerability of the propesed project lo seismic activity was condusted. Because of the pit's high walls, personed in the pit at the time of earthyuake activity could be exposed to the risk of eollapse of the walls or portions thereol. The potential for scismic antivily will have to be assessed if a full feasibility study for the project is conducted. The implicantions of any anctivity to the plant complex and particularly to the mining operation will have to be analyacd.

\subsubsection{Noise Impacts}

Controlled use of explosives (seguencing the chatreges), cenclesing the crushing plant expupment, and through muffling truck and other mining exuipment exhauss.s would likely minimize project noises. Permanent residential development is toe distant to be signilicantly alfected. Seatsonal shepherds and their herds move

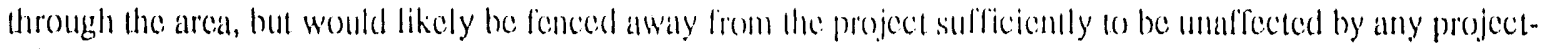
related noises. Protection of workers would be the chicel concern. 


\subsubsection{Secondary Environmental Impacts of the Proposed Project}

The major secondary environmental impacts of the proposed project enter on whether or not a support community for the project's construction and operations personnel is built. If built at the plant site, impacts on water systems would be the main concern. Such impusts could be controlled through centralized planning of the community and its waste and water systems. The Bechel Ciroup plans to use package integrated waste/water systems to accommodate a community of up 604()$(0)(0)$ eople at the plant/mine complex site. With propser design and operation, the existing environmental systems and the proposed water alloument for this project can accommodate such development.

If we addittonal construction and operational workers are drawn from nearby communitics such as Qatranch, Karlak or from the El Abitad phosplate minhe complex and its support communities near El Hasa, the secondary impacts would be dispersed among existing communilies will existing waste and waler systems. No analysis was mate regarding these communities' inl'astructures to support additional workers. A'T line feasibility stage of the project assessment, the declsion regarding whelher or not to build a community al the mine site would have to be made and the impacts of it vis-it-vis the extra burdens on existing communities would have to be assessed. If existing eommunities are the residential sifes for the construction and operating personnd, the project owners

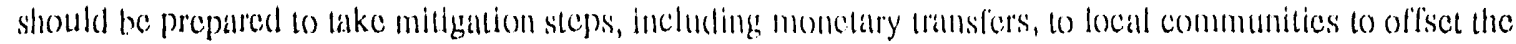
extra infrastructure and fiscal burdens (police and liere protection services, for example) encountered in supporting up to $40(0)$ additional people.

\subsubsection{Cumulative Impacts}

The major cumblative impacts that could be ussocianded with construction and operation of this proposed plant would be those that would accompany the development of an oil shald mining and processing industry in the

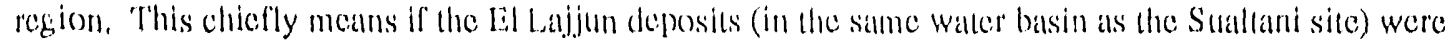
developed into a retorting facility for oil production. "Ihe dominant cumulative impacts of these two major facilities would be on water cuantity and gluality and the secondary inpacts of supporting the construction and operation persomel for the two plants. It is the incention of the planners of the El Lajiun lacility to pump and treat water from the deep alguifer to meet the phant's needs, hus not causing any immediate stress to the existing

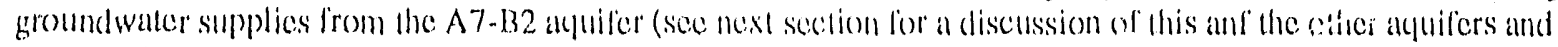
of groundwater cuantiley). Sources for the polable water for the additional workers have not been publiahed in any preliminary plans. The guality of the water frem the vartious plane waske streams would have wo be carefully monitored because of the high risk of contaninaltion by organic loxics. With the construction and operation of elther plant, water supplies would be unavailable for tise in meeting the municipal and industrial water demands of Amman or Karak.

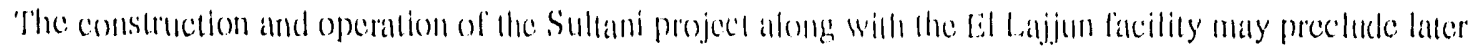

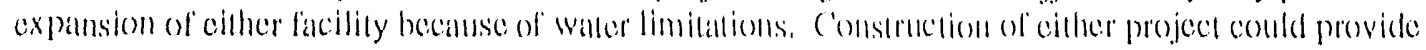

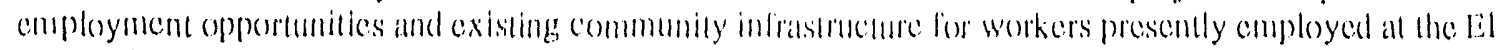

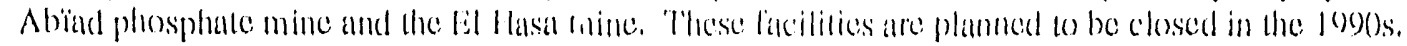

\subsubsection{Conclustons}

1. There are no likely significant. impacts on phant or animal resources.

1 There has been extensive werk undertiken in llo U.S. public and privale sectors to determine the degree of pollution control that will have lo be ased by managers of oil shale lacilities to protect

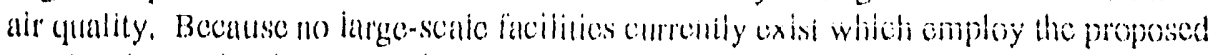
combustion technology with the preposed lied type, lhere have been no opportunities to verify 
projections arising from recent comparable work or to make informed projections for new fucls in new locations with new technologics. Dispersion conditions in Jordan are different than in the Western U.S. Air modeling methods are not fully adeguate even in the U.S., and background data for Jordan for the Sultani area are non-existent. Therefore it is not possible to make other than a preliminary judgment bout the potential impacts oil shale mining and CFBC technology would have on air quality at various tevels of shate oil production. Air dispersion modeling would have to occur at the full feasibility stage of the proposed project. At that time, pre-project modeling approximating the air quality regulation approval process used in the U.S. could be periormed.

Q Studies of occupational discases among oil shale miners in the U.S. have been limited because relatively few people have worked in such mining operations and for relatively few years. The Soviet experience in Estonian mines suggests that workers should be monitored for evidence of pulmonary fibrosis. Although conditions there are no translatable to Jordan, the incidence of respiratory discases in other industries indicates that exposure to the shale dust.s and ashes at the Sultani project could be hazardous. The dust particles from the ash or from the raw oil shale fines would likely be low in silica content (except when cherty materials would be run through the boilers), therefore minimizing the threat of silicosis to plant and mine workers. Worker controls through breathing masks are likely to be difficult to enlorce. The appropriate precautions would be to make cvery effort 'o limit and suppress dust and ash particles and to put in place a long-term program to monitor miners' and plant workers' lungs ard general health. Such a health monitoring program should include periodic examinations and systematic record kecping. Worker training programs, including an intensive training program for new workers and refresher courses for all workers throughout their careers are essential.

$\square \quad$ The land reclamation program proposed for the Sultani project is generally reasoniable and responsible. Highwalls in the excavation pit need to bu eliminated before abandoning the mine sile. More studies of revegetation drategies should be underlaken than are suggested in the current report.

a Consideration of using the fly ash as all annendment to cement, aspialt, or other construction maierials both as a profitable venture and as a means to decrease the quantities of material to dispose is $F$ mature at this stage of the analy'sis given the current market glut for such materials (both domesuc and export), the uncertain luture market, and the existing and future Jordanian capacity for producing cement. It is impossible to plan for the use of the ash at this time. Transportation of a bulk material such as cement from the Suliani site to the port at Agaba is currently too expensive for Jordanian cement 10 compete other international suppliers. Under any foresecable positive market and product-suitability combinations, it is unlikely that :. ty ignificant reduction ... ash wastes could be achicved through this proposed use of ti: 2 ash.

$\square$ Erosion and sedimentation controls, both short- and long-term, durin:: mining and waste disposal appear adequate. Flash fexd events need to be considered in the ${ }^{--}$erering of sedimentation ponds, ditches, and other erosion control structures.

D Controlled use of explosiv s (sequencing the charges), cnclosing tie crushing plant equipment, and through muffling truck and other mining equipment cxhausts we'dd likrly minimize project noises. Permanent residential (Beduin populations are too distint to be significantly affected. Protection of workers would be the chicf eoncern.

13 There is ample surface area availatio at the Sultani site for permanent storage of mine and plant wastes. The Bechtel Group's land reclamation program pr ;osed for the Sultani project is 
generally reasonable and responsible. Because of the available space, safe and aesthetically pleasing slopes and heights for the out-of-pit disposal pile should be casily achieved through appropriate and sensitive enginecring practices.

- Exhaust gases from the plant's boilers would likely be within acepted international (World Bank) limits to control cmissions and ambient concentrations of $\mathrm{SO}_{2}$ and $\mathrm{NO}_{\mathrm{x}}$ (but dispersion modeling would be needed for greater confidence in this judgment).

$\sqcup$ According to laboratory analyses of the leachate from the ash from the iest burn, ash disposal from the proposed facility appears to pose some risk of groundwater contamination. Concentrations of chromium, sclenium, and possibly arsenic could exceed U.S. drinking water standards. Appropriate monitoring and backlilling precautions would have to be taken (see Section 7.4).

\subsection{WATER AVAILABILITY AND QUALITY}

The availabilily and gluality of Jordan's water res trees are the major environmental concens in the country. Water resources in Jordan are becoming increasingly scarec and increasingly expensive to exploit. North Jordan has at least 95 percent of the country's population (the Amman area itself creates 70 percent of the country's water demand), but has only 55 pereent of its surface area. Groundwater and surface water supplies in the north are extensive, but insufficiont to meet all denands for irrigalled agriculture, domestic needs, and industrial applications. Groundwater resourees in the extreme southeast are alse extensive, but remote from demand centers.

Irrigated agriculture presently accounts for 76 percent of water consumed in Jordan. With population growing at 3.8 percent per year (and expected to slow to only 3.2 pereent by 2010) and generally rising incomes (per capita GDP was equal to U.S.\$1,560 in 1987, but has fallen in the past 18 months due to severe economic problems in Jordan), demands for municipal and industrial walter will only increase.

The World Bank believes that nearly as much land is under irrigation as can be accommodated in a sustained manner. Increases in agricultural production will have to come from efficiency improvements in water use and from new technologies rather than from expanded irrigated acieage. Therefore, water requirements for irrigation in the year 2015 are expected to be only 61015 pereent higher than 1986 levels. Municipal water requirements, on the other hand, are expected to triple over the next 3 ) years. Projections for municipal and industrial (M\&I) consumption in future years are consistent with other arid countrics.

The projected strong increases in demand for municipal water come not just from population growth. Improved levels of service, such as the number of private residence connections, are expected to increase in urban areas from 85 pereent in 1985 to 100 pereent in 1990), and in rurat areas from 17 percent in 1985 to 40 pereent in 1990 and 65 percent in 2005. The World Bank reports that 'ordan's estimated overall municipal per capita water requirements $(135 \mathrm{~L} / \mathrm{c} / \mathrm{d})$ in 2015 would be well below present levels in industrialized countries $(250-4(0) \mathrm{L} / \mathrm{c} / \mathrm{d})$ and reflect the high cost of walor in its arid envirommenl. Table 7.16 shows projected municipal water demand for the country as a whole and for the urban areas relevant to the current study.

M\&! water coneumption as a pronortion of total water consumption is expected to increase from 24 pereent in 1985 to 30 percent in 2005 and 45 percent in 2015.4 All demand for water is expected to excecd sustainable supply by about 2010. Mecting these competing demands will re(puire serious negotiations with those needing

\footnotetext{
4 The Wurld Bank, Jordan Water Resources Sector Studly, The World Bank, Infrastructure Operations Division, Country Department III, Europe, Middle East and North Africa Regionlal Oflice, Report No. 7(K)9-JO, June 27, 1988 (restricted use document).
} 
water for irrigation. According to the World Bank, the Government of Jordan will have to consider either (1) using water stored behind the yet-10-be-built Wahdeh Dam entirely for M\&l use and reducing total water availability in the Jordan Valley to about $310 \mathrm{Mm}^{3} / \mathrm{y}$, or (2) overpumping from the Disi reservoir (not a sustainable or acceptable long-term strategy), or (3) developing new walter sources (c.g., demincralization, importation, etc.). These options are discussed below.

Table 7.6 Municipal water demand projections (selected governorates)

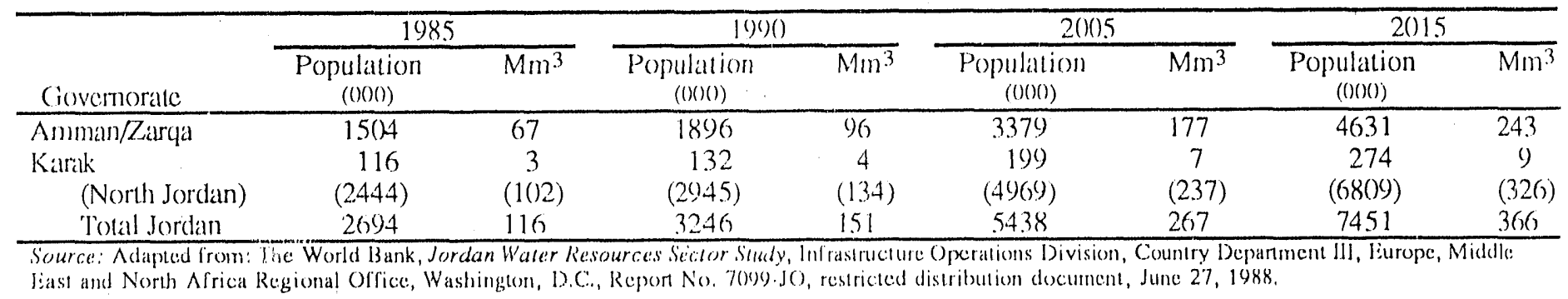

\subsubsection{Water Availability}

There is great interdependence among surface and groundwater resources and agriculture, municipal, and industrial demands for Jordan's limited water. Allocation decisions have lo take into account this interdependence and the somelines deficient information on groundwater resoureses and hydratulic behavior.

\subsubsection{Surface water resources and use in Jordan}

The Yarmouk and Zareja rivers are the main surfice waler resources in Jordan. Most surface waller consumption (World Bank estimates the tolal for 1986 to be $336 \mathrm{Mm}^{3}$ ) is for irrigation: $102 \mathrm{Mm}^{3} / \mathrm{y}$ for upland irrigation and $229 \mathrm{Mm}^{3} / \mathrm{y}$ for irrigation demand in the Jordan Valley. The World Bank helieves that the main potential (and last remaining investunent options) for effectively increasing the use of surface water resources in Jordan lies in the construction of new water storage facilitics on the Yalmensk River, the Jordan Valley, and on rift-side wadis. Projects currently under study (the Wahdeh Dam, Karameh Dam, and Side Wadss) is estimated at 300) Mm³

Around $10(0)$ springs (ain) have been identified, with water quantity and quality measurements made on $9(0)$ of these. Total volume of spring water in Jordan is $23.3 \mathrm{Mm}^{3} / \mathrm{y}$. 


\subsubsection{Groundwater resources and use in Jordan}

The oldest and deepest Jordanian aquifer is in the Disi stratigraphic group, consisting of sandstones and quartzites. This huge, largely fossil-water aquifer is believed to underlie much of the eastern part of Jordan and much of the Arabian peninsula as well. It outerops only in the southern part of the country, far from demand centers. Its great depth and high salinity make it an unaltractive water source in the northern part of the country.

The next higher aquifer is also extensive across much of Jorlan and belongs to the Kurnub system of sandstoncs. It outcrops in the western part of the country along the eastern banks of the rift-side wadis which drain to the Dead Sca, the Jordan Valley, and the Wadli Araba, Its springs have water that is highly mineralized and warm. The Disi and Kurnub aguifers function much as one hydraulic system. Recharge from higher aguifers through leaking of aguitards and faults is minimal compared to the size of the fossil water storage of the whole system.

The Amman Wadi Sir (from the A7 - B2 group) ayuifer is the largest and most important water-bearing hydraulic system in Jordan. Its carbonate rocks (chert-linestone, sandy limestone, and limestone) form the upper layer of the Western Uplands and are the souree rocks for the Sultani oil shale. This aquifer has the highest recharge rate in the country. In its castern portions, it is overlain by thick aypuitards. Sallinity tends to increase from east to west, relative to distance from the recharge areas.

These hydraulic systems, their uses, and their llows will be discussed in more detail below. In Table 7.17, one can readily see the current importance of and rediance that Jordan places on the Amman Wadi Sir aquifer. Table 7.18 displays the most recent record (1986) of productive uses of the country's groundwater resources.

About one-fourth of the country's irrigation water is pumperd from groundwater reserves. Overdralt - mining of these reserves has oceurred more and more frepuently, will privalte wells for irrigation or industrial purposes exacerbating the situation. The Amlian atra is wilhdrawing its groundwalcrs all a rate about 50 percent above the recharge rate. Groundwater resources with a high ralle of recharge are gencrally of good quality, while groundwater from the deeper ayuifers where recharge rates are low, are generally unsuitable for use due to high salinity.

\subsubsection{Groundwater resources of the Wadi Mujib}

The Wadi Mujib watershed covers an area of $6,59\left(6 \mathrm{~km}^{2}\right.$, spre.deng from just south of Amman (the Quecn Alia International Airport is well within the basin's boundiary) 10 over $115 \mathrm{~km}$ to the southeast. It represents nearly 7 pereent of Jordan's land area. The northern hall of the wallershed is administered by the governate of Amman and the southern half is administered by the governate of Karak. "The population of the watershed is about $80,(0) 0(1985)$, or $12 \mathrm{pecople} / \mathrm{km}^{2}$, and is projected 10 grow 16 alveul 110,0$)(0)$ by $2(0) 5$.

The Wadi Mujib basin consists of two main wadis, the Walla (also known as the Heidan) in the north and the Mujib in the south. These two join to form the Wadt Mujith immedialely upstream from the wadi's Dead Sca cstuary. Numerous tributaries feed these two widtis from gemle slopes on the flat uplands, draining into stecpsloped gorges at the lower elevations. The entire basin is bisected by the Siwalga lault. At the confluence of the two major wadis, the base discharge from the basin's 1 wo main alyufers anounts $10.35 \mathrm{Mm}^{3} / \mathrm{y}$ of water at 1,100 ppm salinity. The Wadi Wala contributes about $2.3 \mathrm{M} / \mathrm{m}^{3} / \mathrm{s}^{\prime}$ ill $750 \mathrm{ppm}$, while the W'adi Mujib contributes ahout $12 \mathrm{Mm}^{3} / \mathrm{y}$ at $\left.1.800^{\prime}\right) \mathrm{ppm}$. 
Table 7.71986 groundwater production $\left(\mathrm{Mm}^{3}\right)$

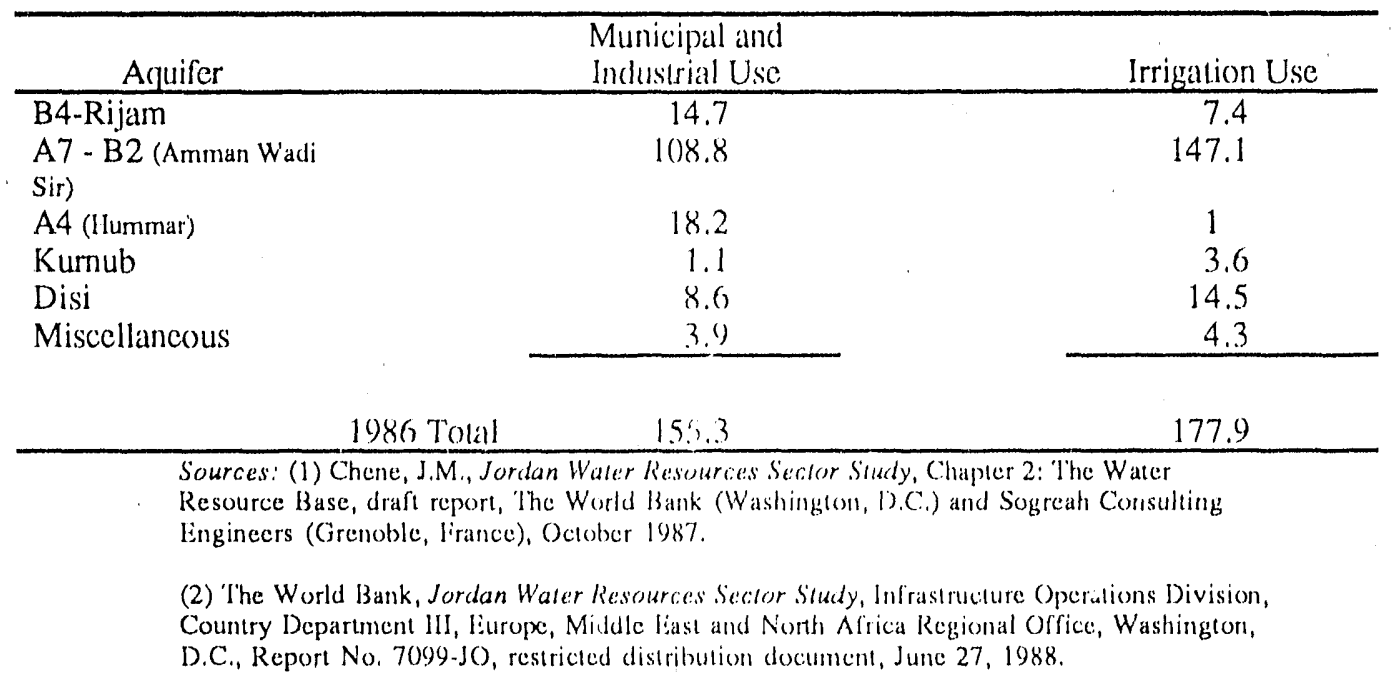

Table 7.81986 groundwater consumption $\left(\mathrm{Mm}^{3}\right)$

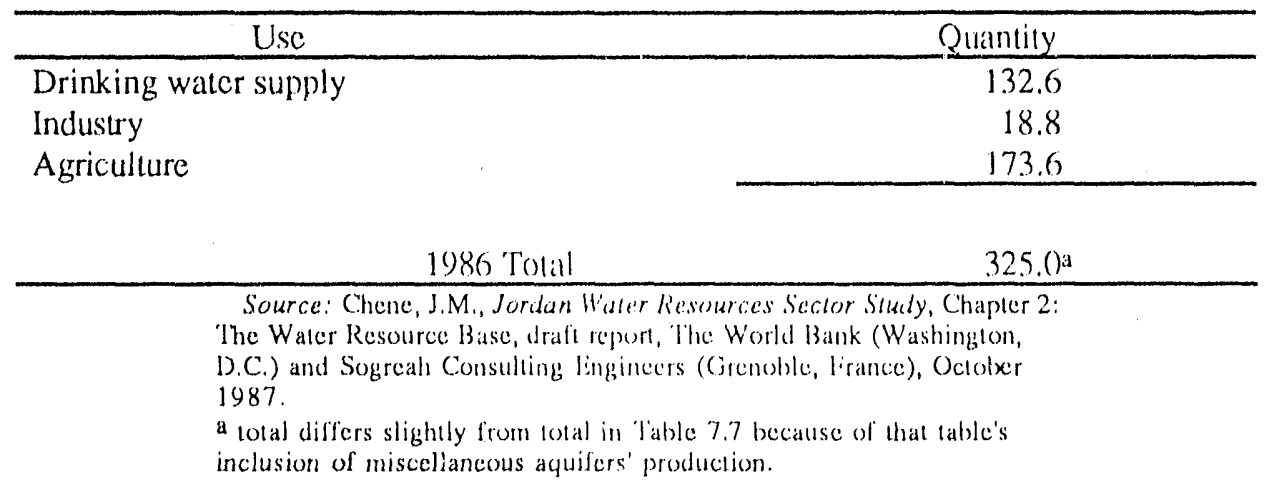

The groundwater potential of the watershed is relatively rich because of the favorable hydrogeology. The two main aquifers feeding the Wadi Mujib discharge are the Kurnub (or K aquifer - sec discussion, below), a decp aquifer with nineral content of up to 2,500 ppm, and the Anman Wadi Sir (termed the A7 - B2 or the B2 - A7, each part of the Balqa/Ajjlun or B/A layer), the main alquifer with the higher-quality water (550 ppm), evidenced by the 155 private wells and $68 \mathrm{GOJ}$-owned wells tipping its depths. Using salt balance as an indicator of source, one can estimate that about 90 pereent of the Wadi Wala base flow comes from the Amman Wadi Sir aquifer and only about 40 percent of the Wadi Mujib's base flow from this shallower aquifer. Table 7.9 summarizes the current uses of the groundwater resources of the Wadi Mujib.

The most important groundwater resources in the southern, and ufper reaches of the basin are found in a band located near the Desert Highway to the south of Siwalja. There are three existing well fields here (Siwaqa, Qatraneh, and Sultani) and two proposed new well fields (Siwala-Qatranch and Sultani). In 1986 the existing 


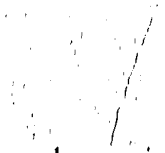

fields were overpumped, underscoring the need to improve alyuifer recharge and the need to protect the aquifer for the proposed new well fields.

The Water Authority of Jordan has stated that the proposed oil shale plant at Sultani may witlit $5 a w 2.0 \mathrm{Mm}^{3} / \mathrm{y}$ of water, and the Bechtel Group has designed the plant and mining operations to work withir. this constraint. At least $5 \mathrm{Mm}^{3} / y$ are available from the shallower aquifer (the $\mathrm{A} 7$ - B2), aceording to studies performed in conjunction with the El Lajjun retorting plant. The proposed termination of operations at the El Abiad Mine site in 1992 may iberate up to $2.8 \mathrm{Mm}^{3} / \mathrm{y}$ of water rights. If these could be transferred to the NRA for its use in the Sultani oil shale operations, most questions regarding grourdwater availability would be moot.

\subsubsection{Surface Water resources of the Wadi Mujib}

Tributaries of the main wadis are dry except for short periods alter rainfall. Constant base flow is seen only on the lowest downstream reaches of the Mujib River, below the King's Highway bridges. Some irrigated farming is dependent on this flow. Base flow is a conslant $1.1 \mathrm{~m}^{3}$, or $35 \mathrm{Mm}^{3} / \mathrm{y}$. During the rainy season, flows increase to $29 \mathrm{Mm}^{3}$ from the Wadi Wala and $36 \mathrm{Mm}^{3}$ from the Wadi Mujib, totalling $65 \mathrm{Mm}^{3}$. These scasonal high flows arc unused.

The upper Wadi Mujib, or the Wadi Mujib proper, has tribularies of the Mujib River and two existing retention dams. These are desert dams, used mainly to retain seasonal rain walers to allow for acpuifer recharge. The Qatranch retention dam is on the tributary Wadi llalira and permits $1.8 \mathrm{Mm}^{3} / y$ recharge in the rainy scason, of which $1.4 \mathrm{Mm}^{3} / \mathrm{y}$ is pumped from new wells in the dry season. The other retention reservoir is the Sultani dam near the proposed oil shale plant. Its reservoir has been almost entirely silled in by processing residues from the El Abiad Phosphate Mine located just south of the dam. Japanese hydrologists estimate that ().9 $\mathrm{Mm}^{3}$ of wastes and sediment will have to be dredged from behind this dam to restore

Table 7.9 Wadi Mujib Basin: current groundwater exploitation (Mm ${ }^{3 / y}$ )

\begin{tabular}{|c|c|c|}
\hline & $\begin{array}{l}\text { W.AJ } \\
(11) 8(1)^{a}\end{array}$ & $\begin{array}{c}\text { JICA } \\
(1987 \text { study })^{b}\end{array}$ \\
\hline Municipal & 18.3 & $\begin{array}{c}16.4 \\
(15 \text { to Amman) } \\
(1.4 \text { to Karak) }\end{array}$ \\
\hline Industrial & $\begin{array}{c}9.6 \\
\text { (wihh Hasis Minc } \\
\text { plus } \\
\text { lal Mbiad Mine) }\end{array}$ & $\begin{array}{c}2.8 \\
\text { (lil Alrad Minc) }\end{array}$ \\
\hline Irrigation & $\begin{array}{c}31 \\
\text { (plus Wadi Wala } \\
\text { springse } \\
\end{array}$ & $\begin{array}{c}14 \\
\text { (plus Wadı Wala } \\
\text { springs) } \\
\end{array}$ \\
\hline
\end{tabular}

a Water Authority of Jordan, Rainfall Dala in Jordan (1969(1-1985), Hashemite Kingdom of Jordan, Amman, jordan, i9oó.

b Japan International Cooperation Agency, llydrologicial and Walter Lise Situdy of the Mujib Watershed, final repon, summary, The lJashenite Kingdom of Jordan, Ministry of Planning in association with the Water Authority of Jordan, No. 103, July 1987.

c $5 \mathrm{Mm}^{3} / \mathrm{y}$ 
its storage capacity. 5 Renewal of former storage calpacily in the Sultani reservoir will permit an additional 0.6 $\mathrm{Mm}^{3} / \mathrm{y}$ of water to be pumped from two additional wedis. Such dredged material would have to be placed in a location where it would not erode back into the drainlige behind the dam. Thus, besides the cnormous quantities of waste materials to dispose for the proposed oil shale plant al Sullani, there appears some likelihood of spoil piles from the dredged wastes from the phosphate mine processing plant.

In its assessment of the feasibility of using desert dauns for recharging acyufers, the World Bank differs from the Japanese hydrologists who also assisted the WAJ in stulying the Wadli Mujib's groundwater potential. The Bank argues that direct recharge is not gutarantecd, in that faulting bencath the reservoir would be required. The small size of the planned and existing reservoirs mean that sedimentation is a constant problem in terms of direct infiltration. Indecd, this can be currently seen right al the Sultani sile. The World Bank argues, therefore, that large dams will need to be built, with water punped and trealed before being injected into recharge wells. The Bank has made quite preliminary identification of iwo larger dam siles with an expected collective yicld of $21 \mathrm{Mm}^{3} / \mathrm{y}$.

\subsubsection{Competing groundwater demands in Jordan}

The World Bank has identified that, in all of Jordant, addlitional groundwaler resources of aceeptable quality and economical exploibability are limited to $44 \mathrm{Mm}^{3} / \mathrm{s}^{\prime}$, given the current understanding of the country's hydrogeological phenomena. Table 7.10) summarizes the current and projected waler balance for all of Jordan, both surface and groundwater resources from 1986102015 . New, more expensive-to-deliver water sources will be needed as soon as 1995 .

\subsubsection{Competing groundwate demands in the Wadi Mujib}

Groundwater in the Wadi Mujib is extensively used. In 1985 there were 223 cxisting wells in the northern part and along the Desert Highway. Private farmers growing vegelables own 155 wells and the GOJ owns 68 wells for supplying water to Amman, Karak, and many small villages within the watershed. In 1985, the Wadi Mujib's groundwater resoures supplied about one-fourth of Amman's consumption.

Demands on the Wadi Mujib's groundwater resources come from proposals for more municipal and industrial water for Amman, the proposed oil shale plants at El Lajjun and Sultani, a proposed chemical/industrial complex beside the Dead Sea, and irrigation water for a 378 ()-hit expansion of the Southem Ghor Irrigation Project, south of the Dead Sea.

World Bank staff believe that the Wadd Wala-Mujib biasin is chose to its maximum salfe yield in terms of irrigation and M\&I pumping, and that expanded pumping from the Amman Wadi Sir is inadvisable so as not to dry up springs that furnish water for local irrigation schemes. According to the Bank, additional water resources should be taken only from the lower portions of the wadi, from the base flow downstream of the Wala bridge. The Bank estimates that about $10 \mathrm{Mm}^{3} / \mathrm{y}$ is all that is aviliable as the additional safe yicld for the basin as a whole, and that this yicld should be allocated to Amman, alssuming that Karrak's water needs can still be met through use of local resources. The Bank suggessls strict controls over new pumping in the uplands and limitation on new irrigation in these areas. Carchul study is recuired before liberating, at most, up to $25 \mathrm{Mm}^{3} / \mathrm{y}$ (salinity of $1300 \mathrm{ppm}$ ) for the large irrigated agriculture project or for the chemical/industrial complex.

\footnotetext{
5 If the proposed oil shate plant needs more groundwater ihan W'N. is willing to sommit, a negoliated dredging of these sediments through use of the heavy equipment (c.g., from the firm contracted to (pverate the oil shate mining operation) already near the site could be an option to liberate up to $0.6 \mathrm{Mm} 3 / \mathrm{y}^{3}$ of water.
} 
Table 7.10 Water balance in Jordan, 1986-2015 (Mm11/y)

\begin{tabular}{|c|c|c|c|c|c|}
\hline & 1986 & 1995 & $20(15$ & 2015 & $(2015) \mathrm{c}$ \\
\hline \multicolumn{6}{|c|}{ M\&II Consumplion } \\
\hline M\&I & 155 & $2(17$ & 254 & 389 & (351) \\
\hline $\begin{array}{l}\text { groundwater } \\
\text { M\&I surface } \\
\text { water }\end{array}$ & 5 & 38 & 99 & 147 & (147) \\
\hline $\begin{array}{l}\text { Subtolal } \\
M \& I\end{array}$ & 160 & 24.5 & 353 & 498 & $(498)$ \\
\hline \multicolumn{6}{|l|}{ Unland Irrigation } \\
\hline $\begin{array}{l}\text { Irrigation } \\
\text { groundwatert }\end{array}$ & 178 & 1.52 & 1.36 & 136 & \\
\hline $\begin{array}{l}\text { Irrigation } \\
\quad \text { surface waterc }\end{array}$ & 102 & 102 & 102 & 102 & \\
\hline $\begin{array}{l}\text { Total Upland } \\
\text { Irrigation }\end{array}$ & 28() & 2.54 & 2.38 & 238 & \\
\hline \multicolumn{6}{|c|}{ Jordan Villey Irrigalliond } \\
\hline \multicolumn{6}{|c|}{ Valley Irrigation } \\
\hline $\begin{array}{l}\text { Subtotal } \\
\text { Irrigation }\end{array}$ & 518 & 574 & 576 & 595 & $(549)$ \\
\hline $\begin{array}{l}\text { Grand } \\
\text { Total W }\end{array}$ & $\begin{array}{l}678 \\
\text { Vater }\end{array}$ & $-\frac{819}{\text { Consumption }}$ & 929 & 1093 & $\overline{(1047)}$ \\
\hline \multicolumn{6}{|l|}{ Walcr Yicld } \\
\hline Groundwater & 333 & 359 & $?()$ & 475 & \\
\hline Surface water & 336 & 424 & 46.3 & 46.3 & \\
\hline Recurn flows & 9) & 36 & 76 & 105 & \\
\hline $\begin{array}{l}\text { Total } \\
\text { Water } \\
\end{array}$ & $\begin{array}{l}678 \\
\text { Yield } \\
\end{array}$ & 819 & 929 & 1043 & \\
\hline
\end{tabular}

Source: The World Bank, Jordan Water Resourses Sector Simdy, Inltitstructure Operation: Division, Country Departunent III, Lurope, Middle liast and North Africa Regional Oflice, Washingtons, D.C., Report No. 7(1)y)-J(), restricted distribution document, Junce 27 , 1988.

a municipal and industrial water

b Includes $46 \mathrm{Mm}^{3} / y$ groundwater irrigation in Jordan Valley for los6s, this is likely lo decline with conversion from surface to drip irrigation; the extent of the decline has been tentatively estimated at $28 \mathrm{Mm}^{3} / \mathrm{y}$. The groundwater is not included for planning purposes by WAJ. It is also assumed that groundwater extraction for irrigation from Wadi Ajib, currently overpumped, is reduced by 10) $\mathrm{Mm}^{3} / \mathrm{y}$.

c excludes irrigation in Jordan Valley

$d_{\text {refers only to area between Yarmouk and the De ad Sca }}$

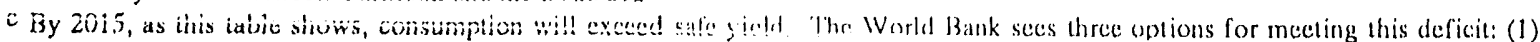
to overpump from the Disi aquifer, (2) to use all we Wahdeh Dam water for M\&I and reduce irrigated agriculture in the Jordan Valley, or (3) to exploit yet-unidentified sources. The figures shown here in parenthesis refer to the results that might be achieved by cmploying the second of these strategies. 


\section{El Lajjun}

Oil shale deposits at El Lajjun ( $25 \mathrm{~km}$ to the west-northwest, see Figure 1.1) have been studied by the NRA and foreign assistance teams since 1968. In 1980) the NRA initiated a contract to conduct a technical and economic prefeasibility study for an oil shale retorting complex there. The proposed plant would have a capacity of $50,000 \mathrm{bbl} / \mathrm{d}$. Several studies have followed this initial one as the subject plant has been investigated in more detuil.

The latest enginecring studies for the proposed oil shale retorting plant at El Lajjun initially stated that the plant would require $22 \mathrm{Mm}^{3} / \mathrm{y}$ for a period of 30 years (the lifelime of the oil shalc resource under exploitation) for optimal functioning. Surface water is not available in

the immediate El Lajjun area because there are no nearby sites suitable for impounding scasonal waters. If built, the plant would need to rely entirely on groundwater resouress. Based on recent findings (discussed in Section 7.5.3), it was concluded that the El Lajjun plant cannot safely withdraw $22 \mathrm{Mm}^{3} / \mathrm{y}$ from the shallow aquifer in the immediate surroundings $(<10 \mathrm{~km})$ of El Lajjun. At $5 \mathrm{Mm} 3 / \mathrm{y}$, the El Lajjun plant's 30 years of groundwater withdrawals were projected to cause these impacts after 40 years:

- maximum nodale drawdown in licld $=91 \mathrm{~m}$

- additional drawdown at:

- Ghuweir $=$ nonc

- Siwaca/Qatraneh = none or marginal

- Sultani $=$ none

- Influence of drawdown on spring- and base flows at:

- Ain cl Lajjun = driced up

- base flow in the upper Wadi Mujib = almost dried up)

- Ain Sarah = none

The plant's designers and hydrogeological consultants juelged these withdrawa! impacts on the shallow ayuifer to be acceptable (although not negligible) even though a "mining" condition would be created. To mect the additional water requirements for the proposed oil shale plant, $17 \mathrm{Mm} 3 / \mathrm{y}$ of water were determined to be feasible to be pumped from the deep aquifer. This water would be available in two locations: (1) at pumping depths of 400 to $500 \mathrm{~m}$, but with long pipelincs (approximately $30 \mathrm{~km}$ ) to the plant; and (2) at El Lajjun itself, but with high $(1000 \mathrm{~m})$ pumping lifts.

If the shallow aquifer we re to be entircly avoided, the dece aluifer appears to have - accurate quantitative data are lacking - ample reserve: (an estimated annual throughpul of approximately $57: \mathrm{Am}^{3}$ ) to accommodate all the water needs for the El Lajjun plant, albeit at higher pumping costs. The ecological impacts of taking nearly half of the aquifer's discharge into the Dead Sea are unknown and unstudied at this point. The opportunity cost of taking future drinking water for use in processing oil shbale is another unstudied consideration.

\section{El Abiad Phosphate Mine}

Plans for terminating mining in carly $1992^{7}$ would liberate $2.8 \mathrm{Mm}^{3} / \mathrm{y}$.

\footnotetext{
${ }^{6}$ Nodal drawdowns represent a mean value of dratwdewn calculited for an arca of two times $2 \mathrm{~km}^{2}$ each. They represent the

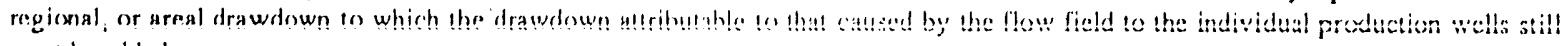
must be added.

7 The World Bank, Staff Appraisal reporl, IJashemite Kingtlom of Jordun, Shildiya Phosphate Mine P'rojecl, Iinergy Division, Asia Technical Department, Washington, D.C., Report No. 6932-JO, restricted report, December 18, 1987.
} 


\section{Sullani well fields}

Well ficlds of Sultani (Mahaltat el Manzil) and Wadi El Abiad supplying farmland, the phosphate plant, and municipal water for Karak by pipeline (production in $198.5=4.2 \mathrm{Mm}^{3}$; sustained yiclds estimated al 6.3 $\left.\mathrm{Mm}^{3} / \mathrm{y}\right)$

WAJ plans 18 production wells here and a $11.7 \mathrm{~km}$ - 6 : $: \mathrm{gg}$ pipeline $(50()-6()) \mathrm{mm}$ in diameter) 10 connect the wells to the Sultani reservoir and a $23.1 \mathrm{~km}-$-long pipeline $(660)-70(0) \mathrm{mm}$ in diameter) to connect with the Siwaça reservoir.

\section{Siwaqa-Qutraneh well field}

Water pumping for the water supply of Amman (proluction $15.9 \mathrm{Mm}^{3} / \mathrm{y}$ ) and for an irrigated farm at Qatranch. The $15.9 \mathrm{Mm}^{3} / \mathrm{y}$ comes from $6.3 \mathrm{Mm}^{3} / \mathrm{y}$ from the sustaned yield from the Sultani well fields and $9.6 \mathrm{Mm}^{3 / y}$ from the Siwacat-Qatranch well fickds.

There is a WAJ proposal to connect by pipeline the Sullini well fields and the Siwalya-Qatraneh well fields south of Siwaca (21 production wells) to the Yadudah-Siwajal pipeline (also proposed, and scheduled to connect 10 Amman) in Siwaya. This whole proposed complex is known als the Sultani-Siwaca Pipeline Project and is considered to be an integral part of the comprehensive plan lo develop the ground water potential of the whole Wadi Mujib basin.

\section{Ghuweir well field}

near Karak, partially supplics this area of the walershed wilh drinking water $\left(1985\right.$ production $=2.0 \mathrm{Mm}^{3}$ )

Ain Surah

and the surrounding smaller springs that supply water lior irrigation to farmers $\left(5106 \mathrm{Mm}^{3} / \mathrm{y}\right.$ )

\section{El Laijun farmers}

and other small-scale farmers in the upper Wadd Mujib (demand $\left.=0.2 \mathrm{Mm}^{3} / \mathrm{y}\right)$

Proposed Potash Company project on the Dead Sea using Hadi Wala-Mujib water

Water demand for this proposed (feasibility still uncertain) (hemical complex planned to extract valuable mincrals other than potash from Dead Sea brines is esitinated to be $5 \mathrm{Mm}^{3} / \mathrm{y}$ in 1990,8 $\mathrm{Mm}^{3} / \mathrm{y}$ in 1995 , and 15 $\mathrm{Mm}^{3} / \mathrm{y}$ beginnings in 2005 (the Wordd Bank has conllicting informallion here: the same June 1988 source slates that $20 \mathrm{Mm}^{3} / \mathrm{y}$ would be needed in 2005 and $40 \mathrm{Mm}^{3} / \mathrm{y}^{\mathrm{y}}$ in 2(015). Because of this project's location near the banks of the Dead Sea at the bottom of the Wadli Mujib drainage, advantage can be taken of residual base flow in the whole wadli.

\section{Southern Ghor Irrigation Project}

This 3780-ha expansion to the Southern (ihor Irrigalion Project focatted south of the Dead Sea would require 40 $\mathrm{Mm}^{3} / \mathrm{y}$ of new water sources. A proposal is to pump in ground water extracted from groundwater resourecs in the Wadi Wala-Mujib. According to the World Bank, the sourec water development would be in the in the Wadi viujib luwer caichment basin and would include conctrontion of a well and an intake downstream of the Wadi Mujib/Heidan confluence to abstract up to $25 \mathrm{Mm}^{3} / \mathrm{y}^{\text {of }}$ water. Water resources would have to be shared with the proposed Dead Sca brines chemical/industrial processing complex. 


\subsubsection{Water Quality}

\subsubsection{Groundwater quelity}

Groundwater quality in Jordan is diminished by three major faclors: recycled irrigation water, pumping of saline water from decper aquifers, and wastewaler from humbun selltements and industry. The acpuifer (see next section) most likely to be used for the proposed Sultani plant has water that is fairly fresh, with tolad dissolved solids in the range of $50(0)$ to $9(0)$ ppm. The NRA provided tests on waller from wells at the Sultint site and reported readings of $\mathrm{TDS}=75 \% \mathrm{ppm}$ and $\mathrm{pH}=7.36$. Sec Table 7.11 for an elemental analysis of this groundwater.

Table 7.11 Sultanl Ciroundwater Analysis

\begin{tabular}{cc}
\hline Eilemental Analysis & 12)m \\
\hline $\mathrm{Ca}$ & 83 \\
$\mathrm{Mg}$ & 4.5 \\
$\mathrm{Na}$ & 47 \\
$\mathrm{~K}$ & 4.3 \\
$\mathrm{Cl}$ & 17() \\
$\mathrm{SO}_{3}$ & 101 \\
$\mathrm{HCO}_{3}$ & 32() \\
$\mathrm{NO}_{3}$ & 2.3 \\
$\mathrm{TH}^{\mathrm{C}}$ & 392 \\
\hline
\end{tabular}

Source: NRA-supplicd data lo the Bechlel (iroup

7.4.2.2 Protection of water quality and establishmenit of monitoring program

Leachate from the disposed fly ash from the oil shalle combustion proces:is could be placed back in the excavation pit at such a depth as to benefit litte from filtralion through the replaced overburden before entering the water table. (The excavation pit will undoubledly intersect the walter table in places, ${ }^{8}$ ) Because the Sultani well field is nearby, this leachate could be diluted only slightly before being pumped to the surface and piped off to Karak or to Amman for use in municipal water systems. The U.S. RCRA leachate standards are not designed to be applicable in such circumstances. Therefore, chromiun and seleniun concentallions in the drinking water that may flow to these municipalities must be monitored and cerrected as a condition of project financing or construction approval if they exceed saffe drinking, walcer standlands (see Sicetion 7.3.2),

\footnotetext{
8 There is some disagreement within the (GOJ about lle depth of the willer table at the Sultani site. Mr. Badir llerzallah of the WAJ believes that the water table is at only 6) $\mathrm{m}$. Mr. Abu Azumich and N. Kasim (Omari of the NRA believe that it is at $12010180 \mathrm{~m}$.

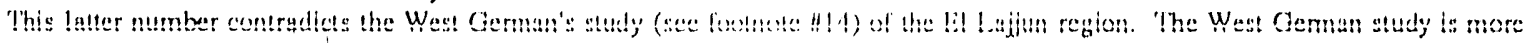
consistent with the WAJ values. The field crew digging the lest burn sanple staled that hey had run into water in their digging at ubout the $70 \mathrm{~m}$ level.
} 


\subsubsection{Groundwater Flow Regimes in the Wadl Mufll)}

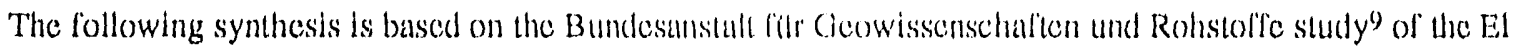
Laijjun arca's hydrogeology.

The most easily aceessible groundwater resources alre hlought to be available in an Upper Cretaceous

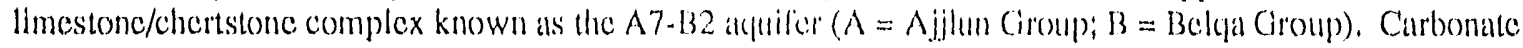
rocks predominate in the system. The A7-B2 is the most importinnt anpuiler in Jordan. It essentially forms the Western Highlands, onteropping in this area of rehiltively high rainliall and thus receiving appreciable recharge. It is up to 300 m thick and underlies most of Central Jordann calst of the kill Valley. The $A 7-132$ is known among local hydrologists as the "shallow alyuiler." In the Sublant area, il can be found all depths of 80 to $95 \mathrm{~m}$.

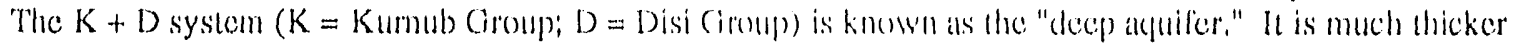
$(10()) \mathrm{m})$ and contains much grealer volumes of waller, but of a low guality. It is the lowest ayuifer, and flows westward, draining exclusively into the lowest base level, the Dead Sea.

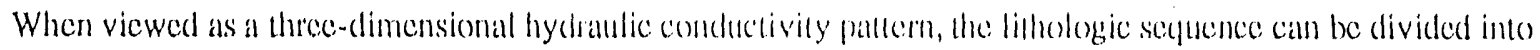
four groups, from decpest to surface:

1. The Kurmub and Disi formation ( $K+1)$, or deep actuifer) with the highest transmissitivity cxisting in the arrea

2. The A 1-A6 alpuitard, a marl and claystone layer

3. The A 7-132 (shallow alyufer) unit formings be upper alyuiferous zone

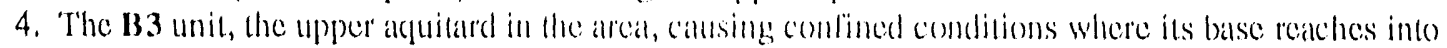
the hydraulic head of the A7-132 alyuiles.

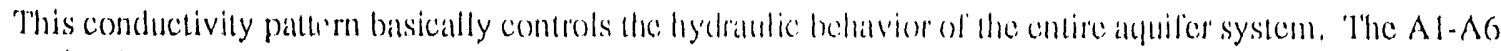

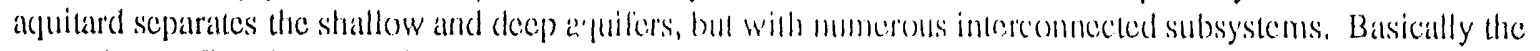

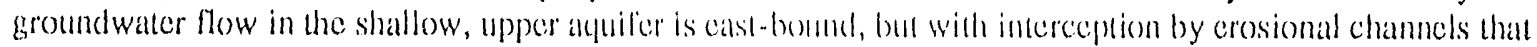
lead to the Rift Valley (and to the Dead Sea) and will downward leakige throngh the Al-AG alutitard into the

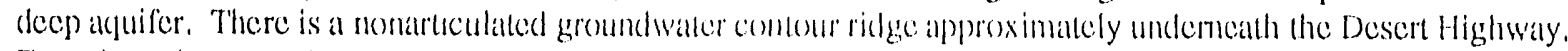
Firom here the groundwater to the west llow's in a westerly dircetion to the Wadi Mujib estuary near the Dead

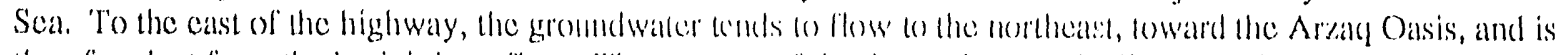
therefore lost from the basin's base flow. The purpuse of the desere dams and ad jacent well fiedds in the Sultani,

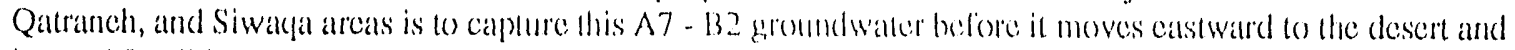

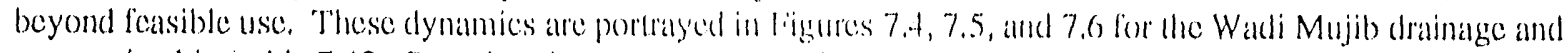
summarized in able 7.12. Bs using the \%ones portray'ed in Figure 7.6 coupled wih the data from T'able 7.13,

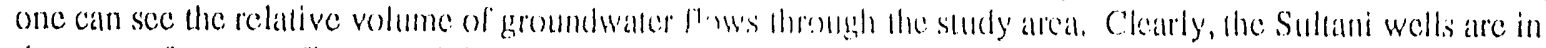

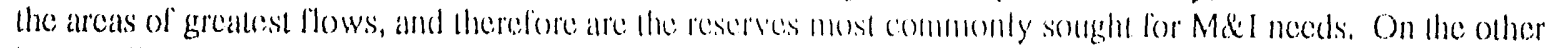
hand, mild polluti on of this groundwater resouree will be rendily dituted in ils grealer llows and volumes.

The Hannover group's study revealed that there alte certain constraints which limit the extration of groundwater from the casily accessible shailow atuifer. One invelved sume permeability details of a laubl line near the El Laijun site. Of more general implication to

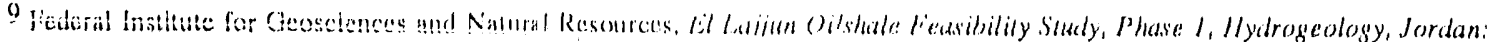

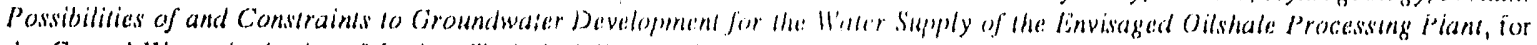

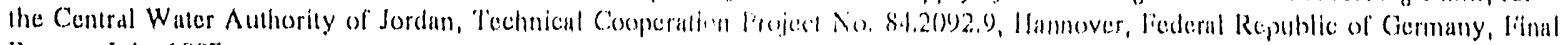
Repon, July 1987.
} 
'T'able 7.12 Results of' modeling Upper Wadi Mujb groundwatur flowsin (Mmil)

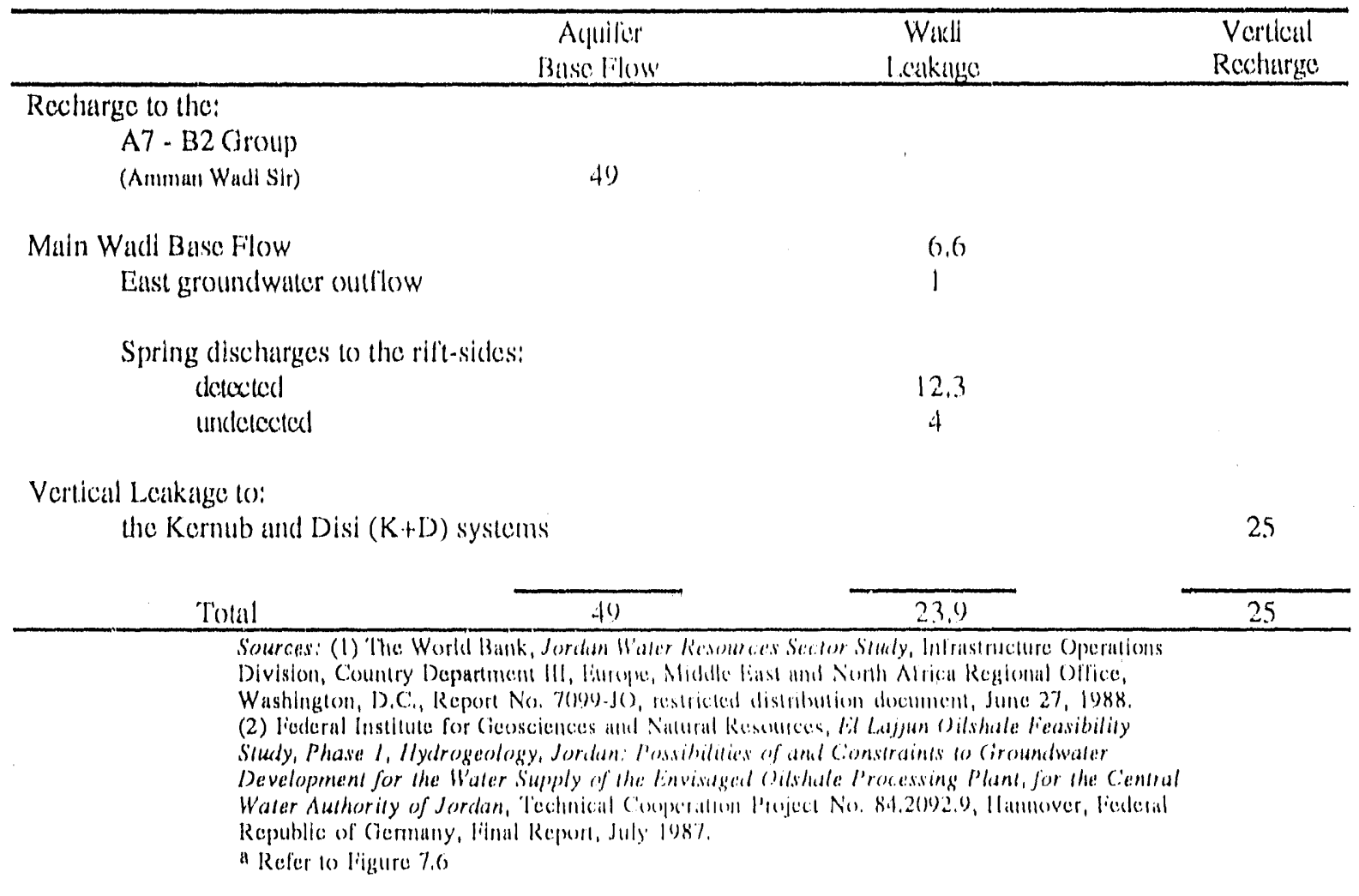

the Sultani oil shale project is the finding that the A 1 -Af alpuitarl is more highly permeable than previously thought. As a consequenee, there is higher loss of groundwater to the $\mathrm{K}+\mathrm{D}$ system, the deep aluifer, than initially understood.

\subsubsection{Oil Shale Plant Water Requirements}

The plant water system consists of a raw water sy'stem, a tralced plant makenp water system, and a plant service water system. The first measure of water conserviltion that line Bechitel (iroup's plans call for would be use of dry cooling towers to remove heat from the steam lurbine exintisl. A small wed cooling tower is used to reject heat to the atmosphere from plant auxiliariess such as asli coolers.

The raw water pumps would provide pumped willer lo lle serviec witter system cooling tower, the beiler trealed makcup water system, treated drinking water, pump scals, and olher miscellaneous uses. Storage tanks for fire protection water would also be served through this system. Water for domestic use would he treated in accordance with World Health Organization standards. The service water system would provide water to the various internal plant operational needs such as condensers and oulfer coolers, It also 


\section{WEST}

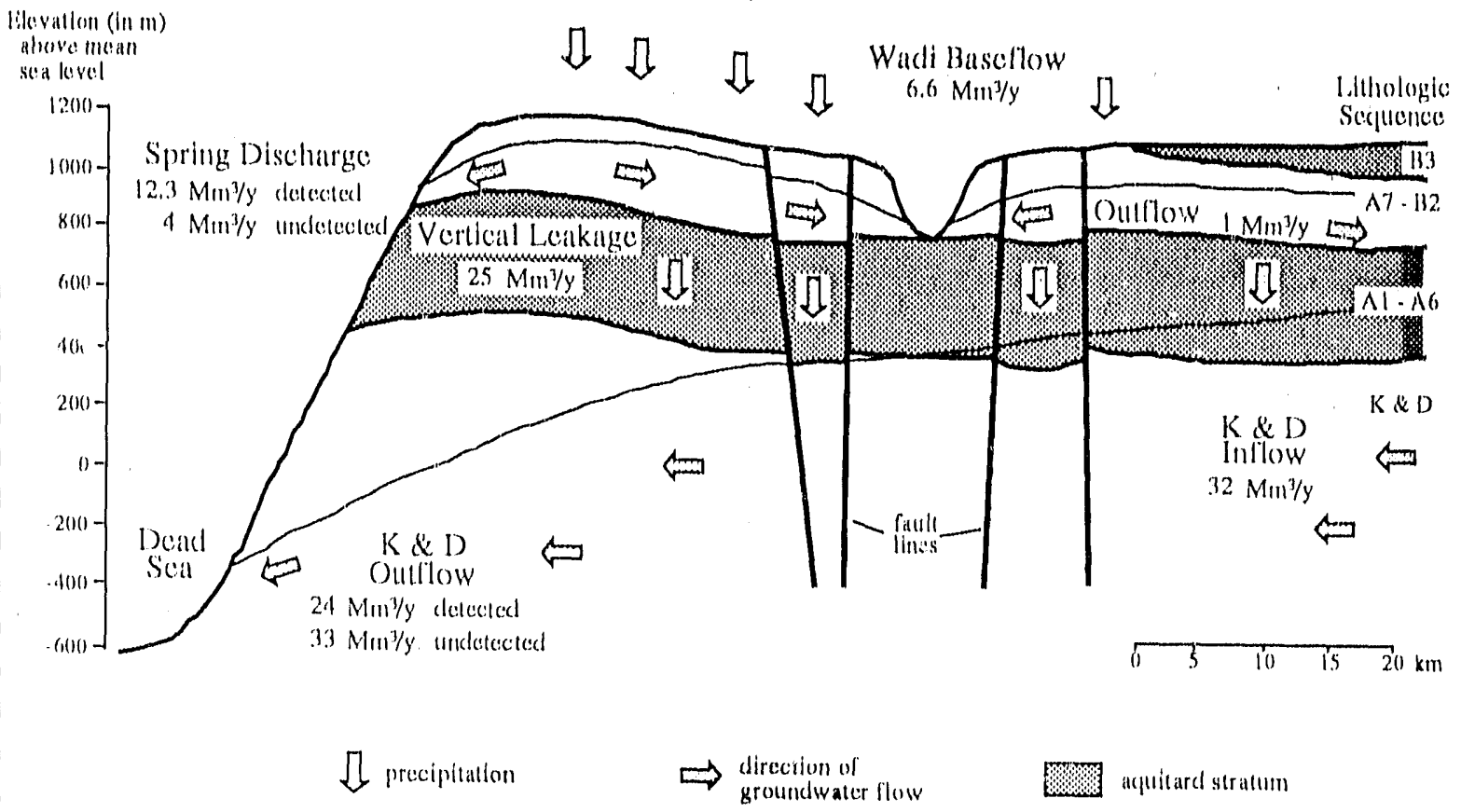

figure 7.4 Groundwater balance for the Wadl Majib drainage

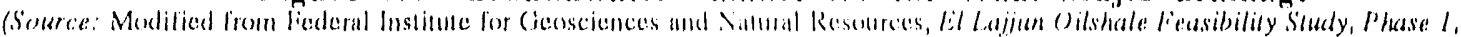

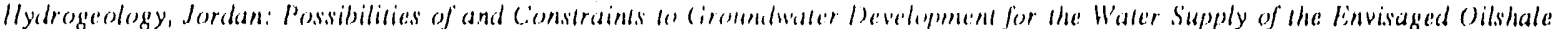

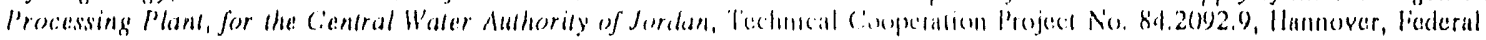

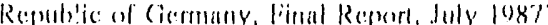

would provide water lor welting the ash to minimise dust during ash handling, Some waste water would also be used lor welling the ash.

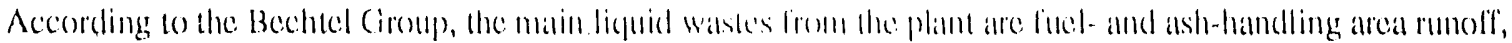

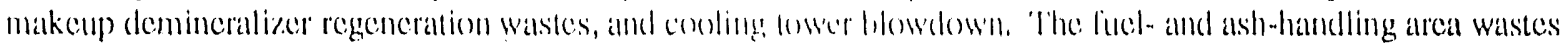

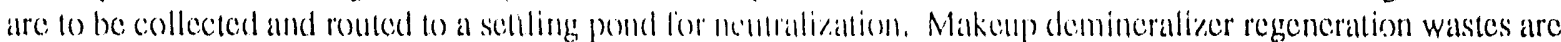

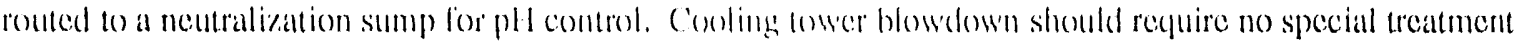

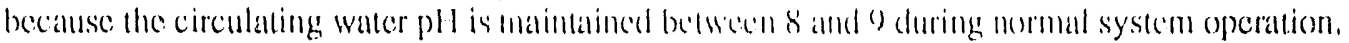




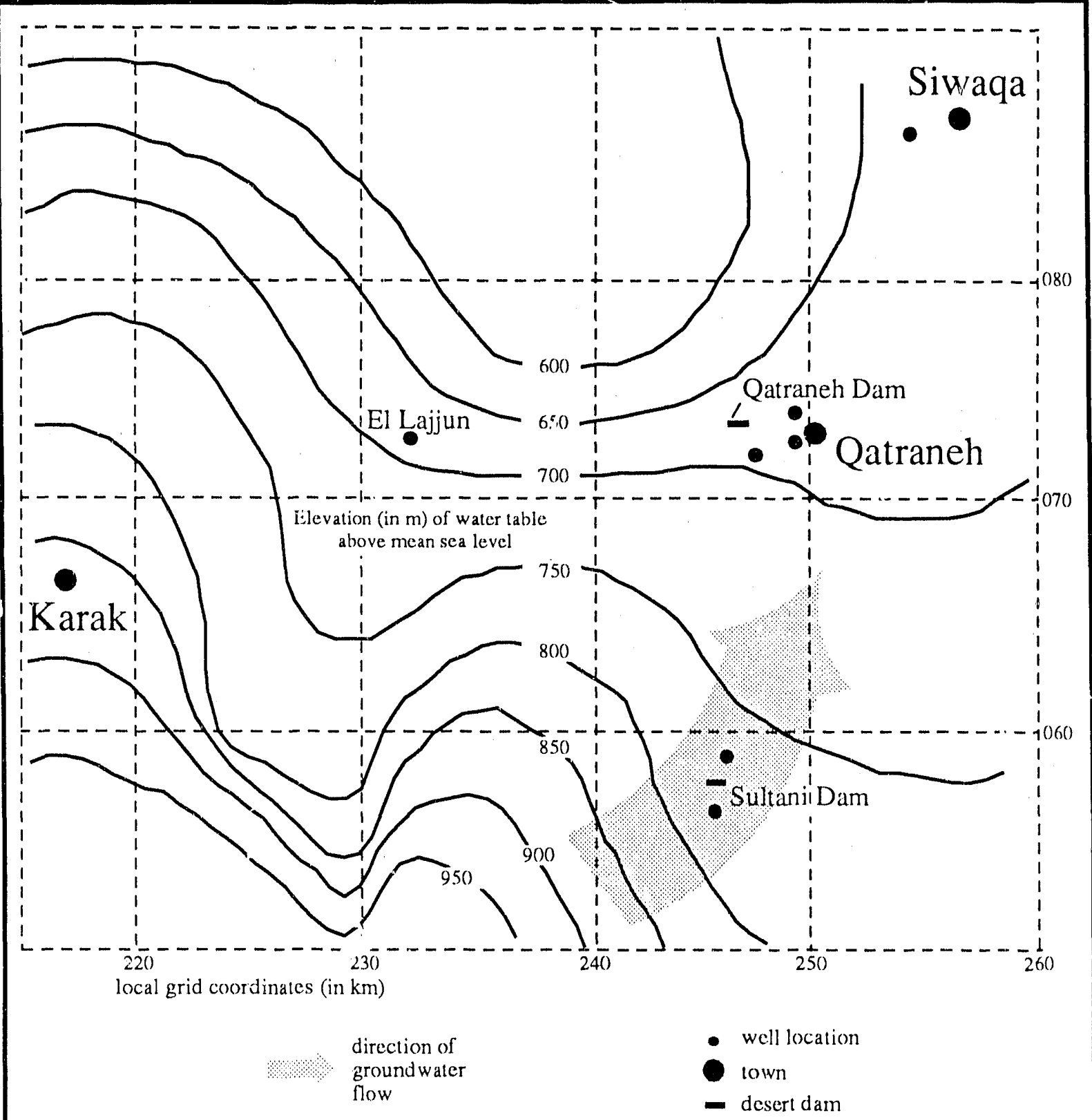

Figure 7.5 Equipotential groundwater map of the El Lajjun area, showing the Sultani site

(Source: Modified from Abu-Ajamich, M., An Assessment of the lit-Laljun Oilshale Deposit, Natural Resources Authority, Hashemite Kingdom of Jordan, Amman, Jordan, February 198() 


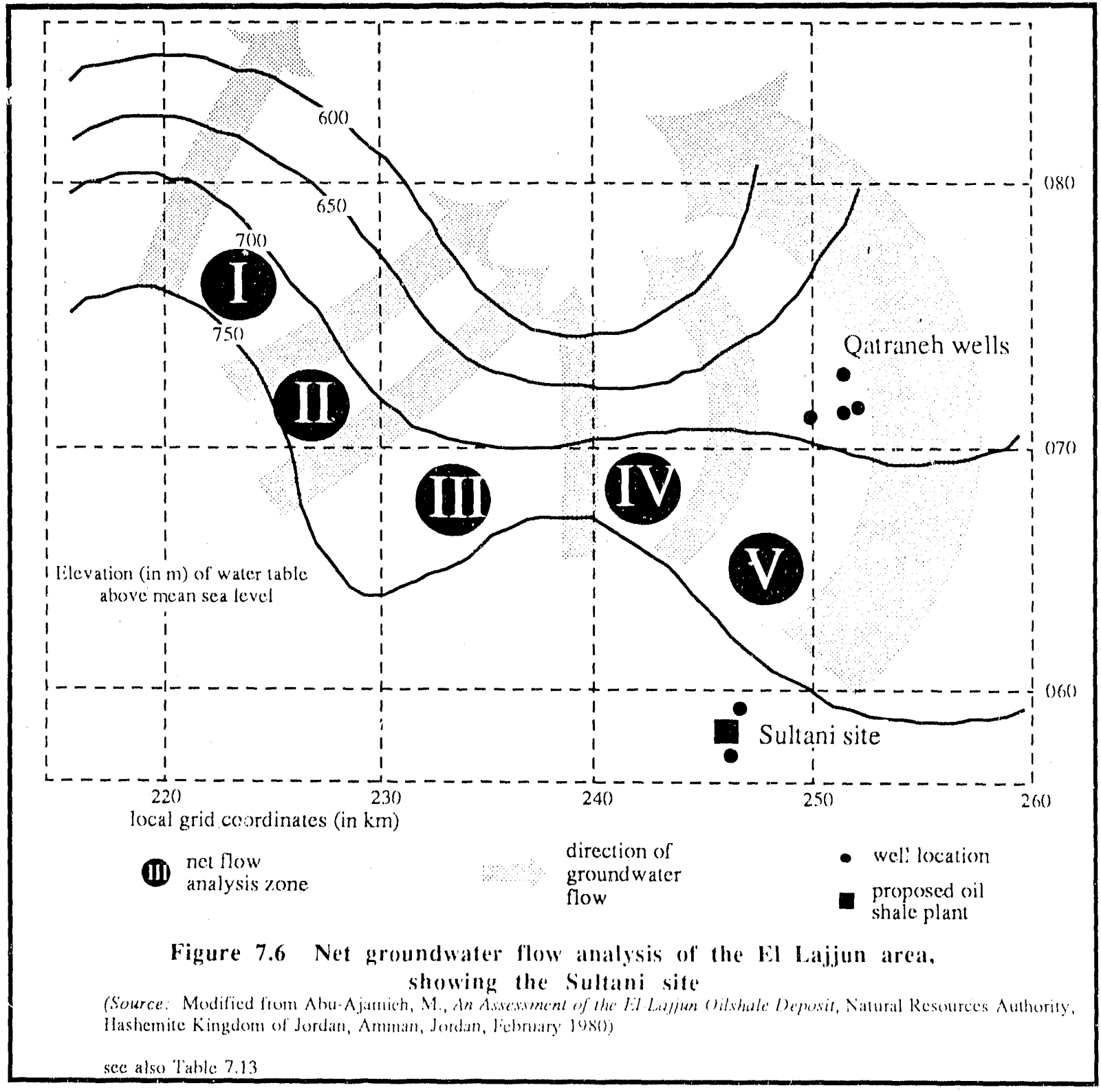

\subsubsection{Potential Impacts of Oil Shale Plant on Groundwater Quality and Quantity}

No serious environmental hazards to water rescurces are anticipated to result from the plant and mine operations. To assure that water resources would te adequately protected, the Bechtel Group has called for environmental baseline studies to be conducted to develop protective measures for both surlice and groundwater supplies. Measures to protect these water resources from coitamination due to mining and waste disposal, particularly after flooding events, would also be needed. The Bechicl Group calls for further testing of the overburden to determine its chemical properties and suitability for revegetation. 
Table 7.13 Net groundwater flow analysis of the El Laijun area, (with the Sultani site)

\begin{tabular}{|c|c|c|c|c|c|}
\hline $\begin{array}{l}\text { Iow } \\
\text { onc }\end{array}$ & $\begin{array}{l}\text { Width } \\
\text { (W) } \\
\text { (m) }\end{array}$ & $\begin{array}{c}\text { Transmissibility } \\
(\mathrm{T}) \\
\left(\mathrm{m}^{3} / \mathrm{d} / \mathrm{m}\right) \\
\end{array}$ & $\begin{array}{l}\text { Hyctraulic } \\
\text { Ciradien! } \\
\text { (1) }\end{array}$ & $\begin{array}{l}\text { Flow } \\
\text { (WTI) } \\
\left(\mathrm{m}^{3 / 4}\right)\end{array}$ & $\begin{array}{c}\text { Flow } \\
(\text { WTI x 365) } \\
\left(\mathrm{m}^{3} / \mathrm{y}\right)\end{array}$ \\
\hline I & $9,600)$ & 3.4 & $(0.01)$ & 326.4 & 119,136 \\
\hline II & 5,000 & 836.4 & (0.01 & $41,9(0) .0$ & $15,293,500)$ \\
\hline III & 7,000 & 13.4 & 0.02 & $1,876.0$ & 684,740 \\
\hline IV & 7,200 & $\begin{array}{l}(2()() .()) \\
\text { estimalet(t) }\end{array}$ & 0.02 & $28,8(0) .0$ & $10,512,0(0)$ \\
\hline V & 7,700 & 702.0 & $\begin{array}{l}(0.0) 1 \\
\text { Total Flow }\end{array}$ & $\frac{54 .(154.0}{126,956.4}$ & $\frac{19,729,710}{46,339,(1866}$ \\
\hline
\end{tabular}

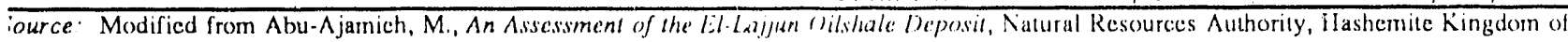
lan, Amman, Jordan, Febraary 1980)

e Figure 7.6

It is the nature of mining activitics such that there will alwaly's remain differences in the hydrologic characteristics between reclaimed areas and undisturted arcis. These differences will tend to influence the infiltration of precipitation, the surface water runolf and gluality, the groundwater flows and quality, and the Jocation and quantities of water discharged at secpes or springs. Becaluse there exist so little site-specific data for the Sultani site, predicting the post-mining hydrogentengical conditions, their scadsonal variations, and their potential variation over the years, it is necessary to bout gillher moere hy drogeological data before beginning the project and to establish a rigorous ground and surfice watcr monitoring plan to enable the entire shale oil industry to learn as much as possible about the envirommintal impacts of this fuel with this technology.

Backfilled material generally has much higher hydraulic conductivity than the original undisturbed bedrock because of the increased occurrence and continuity of liaculures and voids. Undisturbed shales freguently act to restrict groundwater movement. In the proposed batklilled pit, the hydrologic situation would be new and near the current water table. The fracturing and mixing of overhurden materials as well as bottom and fly ash wastes would expose new (and inore) rock surfices to circulating groundwater. Minerals from these newly exposed surfaces may move into solution at enhanced rates compared with rates under the pre-mining flow paths. Thus, the chemistry of groundwater in the backfill of the owerhurden material alone, ignoring the ash backfill, would likely be different from that of the undisturbed overburden. Ficld and laboratory tests of the Green River shales of Colorado suggest that over 90 pereent of the dissolved solute constituents are attributable to particles less than $0.5 \mathrm{~mm}$ in diameter (all the ash wastes from the proposced plant and many of the raw shate fines). These are all further reasons to have a comprehensive walk r moniloring sy'stem.

\subsubsection{Environmental monitoring plan}

As a condition of project financing or construction alpproval, a groundwater monitoring plan should be developed and defined with GOJ of ficials to determine the number and location of sampling stations, the variables to be measured, the sampling frequency and collection methorls, lhe requisite accuracy and precision of the analytical techniques to be employed, and the quality assurance salegutrds to be used. The location of the monitoring wells should be selected according to (1) the localions of polential pollutant sourees, (2) the geology and hydrology of the Sultani site, (3) the probable movement and dispersion of pollutants underground, and (4) the potential for hydrologic disturbances such as dewalcring wells. The wells should allow sampling from different depths, and the chemical and physical elements measured should be selected aceording to hydrological characteristics as well as the properties of the suspected polential pollutants. With the municipal wells for Karak located so close $(<1 \mathrm{~km})$ to the proposed pil, these moniloring actions are essential. Their use to advance 
the knowledge base of CFBC technologies with oil shale fuels further underscores the need for extensive groundwater monitoring.

\subsubsection{Conclusions}

$\sqcup \quad$ Jordan has, from the national perspective, very real water resource problems facing it. There are significant current and future demands placed on the limited groundwater resources in the Sultani area. There would, however, likely be alcejuate groundwater of sufficient quality and at reasonable pumping depths for operation of the propesed plam/mine/waste disposal complex and for meeting future competing necds. The amoun of water the GOJ has allocated for this plant is realistic and adequate.

1] The Sultani area, while seemingly remole, may play a secondary role in helping major 'nunicipalities meet their M\&I needs ais carly as the late 199)s. The Sultani well fields are currently helping smaller communitics such as Karak mect its M\&l needs.

1 Groundwater flow regimes in the Upper Wadli Mujit drainage suggest that leachate from the fly ash that enters the water table with inadecfulate filtration and dilution could cause drinking water problems with municipal users in Ammin or kilrak, now and increasingly in the future. Such an event would have a low probability of eceurrence beciutse of the area's low annual rainfall. M\&I wells for Karak are already within one kilometer of the proposed plant site. Groundwater flow patterns take water from the Sultani areal dircelly into wells there or northward to the Qatraneh (about $10 \mathrm{~km}$ awal') and Siwalya (about $20 \mathrm{~km}$ alwaly') wellicelds.

\lrcorner Care must be taken in the fly ash wasic disposal and reclamation enginecring to optimize fittration of fly ash leachate through replaced overburden hefore it can drain into the Amman Wadi Sir groundwater.

D Monitoring wells and instrumentation or regular sampling are required to assure that water safe from chromium and/or selenium contannination is being pumped from the Sultani and Qatranch well fields. Such monitoring and assuralleces should extend to the post-mining Sultani context. 


\section{TECHNICAL RISK ASSESSMENT}

\subsection{INTRODUC'TION}

Circulating fluidized bed technology in general has progressed to the point that there appears to be no question of its feasibility. Successful operation has been demonstrated burning a variety of solid fucls in plants of up to about $60 \mathrm{MW}$ output. larger plants, up to $110 \mathrm{MW}$, are in the initial phases of operation, and, within the next 2-3 years, should provide much evidence of the viability of larger plants.

The combustion tests of Jordanian oil shale in the Ahlström CFB test unit indicate that the shale should burn readily and yicld low $\mathrm{NO}_{\mathrm{x}}$ and $\mathrm{SO}_{2}$ emissions in a CFB combustion system. The high volatile content of the fuel is a major contributing factor to its good combustion. The major disadvantages of the fuel are, of course, its low-heating value and high ash "ontent. A large fraction of the shale blows through the combustor as fly ash which yields a high ash loading in the hot cyclone and convection tube banks. The primary potential problem areas are associated with the high ash content: (1) bottom ash removal from the combustor, (2) high flow rate of recycle solids through the hot cyclone and return leg, (3) fly ash deposition and erosion of the convection tube banks, and (4) crosion of superheater tubes in the combustor.

\subsection{0-MW PLANT}

The technical risk should be fairly low for a 20-MW demonstration plant. Eighteen plants of this size or larger have been built by Ahlström or its subsidiaries, have operated for a year or longer, and have demonstrated availabilities of 95 percent or more. The major areas of concem are the high flow rate of solids through the hot cyclone and return leg and the high ash loading in the flue gas which may lead to deposition and erosion in the convection tube banks. The design proposed by Pyropower should minimize the risk of deposition or erosion in the convection tube banks because the fluc gas velocities will be low and steam soot blowers will be used.

While the technical risk for a 20-MW plant appears to be low, successful demonstration of this size plant may not provide adequate experience for scaing up to a 100 - $\mathrm{MW}$ plant. It may be necessary to operate a 5()-MW plant before attempting to scale uip to $100 \mathrm{MW}$.

\subsection{5()$-M W$ PLANT}

The technical risk is moderate for a 5)-MW plant. There is some operating experience with plants of this capacity firing coal or other low- to medium-ash fuel, but there is not yet any experience with high-ash fucl in plants this large. A 35-MW plant fired with anthracite culm is scheduled to begin operating this year, which should yield valuable information relative to operation with high-ash fuel.

The major areas of technical risk are associated with removal and handling of bottom ash from the combustor, high flow rate of recycle solids through the hot cyclone and return leg, fly ash deposition and erosion in the convection tube banks, and erosion of superheater tubes in the combustor. The ash flow rate for the 50-MW plant is about 10 times the ash flow rate of the Nucla plant, the largest CFB plant Pyropower has built to date.

\subsection{0-MW Plant}

The technical risk is fairly high to build a 10()-MW plant as the first unit. There is no plant this large operating or under construction which is designed to operate on high-ash fucl. The Nucla plant has an output of $110 \mathrm{MW}$, but it is designed to operate with coal with an ash content of about 20) to 25 percent. There have been some startup problems with the Nucla plant. One problem has been irregular flow of recycle solids in the cyclone return legs, apparently caused by restrictions or plugging from poor fluidization in the loop seals. Experience derived from the 2-year test program planned for the Nucla plant by EPRI will contribute greatly to the knowledge base for design of the larger plants. The high ash content of the Jordan oil shale will make the scale-up to a 100-MW plant for this fuel more challenging than for coal. 


\section{FINANCIAL/ECONOMIC ASPECTS OF THE SHALE ALTERNATIVE}

This chapter addresses both financial and economic aspects of using oil shale for producing power in Jordan. Three plant sizes are considered: 20-MW and 5()-MW demonstration plants, and a 400-MW commercial scale option. The 20-MW and 50-MW alternatives are considered rescarch and development plants; the primary purpose for constructing them is to demonstrate the feasibility of the circulating fluidized bed (CFB) boiler technology and to document the operating experience using Jordan's shale. Of particular operating concern is the materials handling involved in oil shale mining, processing, and spent shale disposal. The 400-MW option is to be composed of four 10()-MW units. However, it is possible to combine the demonstration features of the 5()-MW option and the commercial-scale 40()-MW alternative by first constructing a 50-MM plant, documenting its experience, and then constructing another 5()-MW unit and $3 \times 100-\mathrm{MW}$ units.

The financial analysis below compares the three different oil shale options with (1) the actual financial performance of the $2 \times 13$ )-MW oil-fired units at Acjaba (Açaba I) during the first 11 months of 1987 and (2) the estimated financial performance of $2 \times 13($ )-MW dual-fucl (cual and heavy oil) units also at Agaba (Agaba II) whose construction was recently delayed. 1 The financial comparison is on a cents per $\mathrm{kWh}$ cost basis, including fuel costs, other operation and maintenance (O\&M) expenses, and capital costs.

The economic analysis consists of a series of sensitivity studies for the 2()-MW, 50) MW, and 40)-MW options. For each plant size, the sensitivity studies are conducted using four different assumptions on the operating characteristics of the plant: (1) capacity factor, ${ }^{2}$ (2) average price of electricity, (3) fucl costs, and (4) capital expenditures. The approach is to examine the economic attractiveness of the shale alternatives under the most favorable set of assumptions and then perturb those assumptions to determine the cconomic attractiveness of each of the three plant-size options under less favorable operating assumptions. The results of the sensitivity study are an important factor in deciding whether to proceed with a more in-depth feasibility study of the oil shale-for-power alternative in Jordan.

Before proceding, it is important to define what is meant by financial and economic analyses. Financial prices are those prices that the firm confronts in the marke. They are the prices paid by market participants for inputs and the prices it receives for its output. An alternative way to express this is that a financial analysis portrays the performance of the generating altematives as they impact the financial records (income statement, balance sheet, and funds flow) of JEA.

In the economic analysis, a cost-benefit study of the three shale plants is conducted, taking into consideration the economic cost of the inputs used in producing power. ${ }^{3}$ The costs are capital expenditures, fuel costs, other $O \& M$ costs, and ash disposal costs, while the benefits are revenues that JEA receives for the sale of electricity.

\footnotetext{
1The Aqaba 11 units were originally conceived to be dual-fueled, with coal being the primary fuel. However, a decision was made to use heavy fucl oil as the primary fuel because of the higher upfront capilal costs asscciated with burning coal. A decision was made in 1987 te delay its construction. Current system plannung for the Jordanian power system was discussed at greater length in Chapter 4.

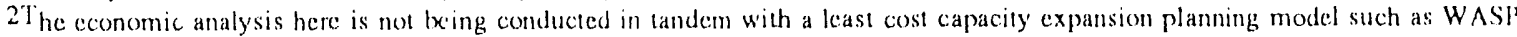
111. An analysis such as this is beyond the scope of this prefeasibility assessment. In the event that a feasibility study is underiaken, a capacity expansion planning model would presumably be used. A model such as WASP would estimate the actual uilization (running time) of 20,50, and 40()-MW plant options based on minimizing system cost, given assumplions about (1) the operating characteristics of all oher plants in JEA's system and the shale alternatives, (2) projected fuel costs, and (3) forecasted electricity demand. In the present study, we simply assume different capacity factors for the three plant sizes in the sensitivity studies. Three capacity factors are used: 50,60 , and 75 pereent.

${ }^{3}$ Financial prices may not reflect the social oppontunity cost of using the inputs in producing electricity. Many interferenees in the market diston financial costs from economic costs. In the developing world, wo of the primary distortions are forcign exchange controls and capital restrictions, two of the most important inputs in constructing power plants. However, in Jordan's case, these two important distortions are insignificant. Therefore, the cost-benclit analysis will be conducted using financial prices.
} 
The technique estimates the present value of net benefits from the project, using a discount rate reflecting the firm's opportunity cost of capital. Net benefits are simply the discounted value of all costs and revenues over the lifetime of the power plant. If the net present value of all revenues and expenditures equals zero (highly unlikely in real-world applications), the discount rate used in the analysis is called the internal rate of return (IRR). If the NPV is greater than zero using a predetermined discount rate, the IRR can be computed.

The cost-benefit technique is commonly used for project evaluation, originating from the type of analysis used by private firms in deciding on investment alternatives. When a firm engages in investment planning, it attempts to select investments that will yield the highest return for a given anount of capital expenditures. The IRR computed for the sensitivity studies is a useful number to compare various power supply options. It can be used as the basis of comparison for toth the different shale plant-size altematives and other generating options such as the $2 \times 13()-\mathrm{MW}$ thermal units proposed ior construction at Ayaba.

The sensitivity studies will be conducted at the individual firm level, the Jordan Electricity Authority. However, a cost-benefit analysis should consider all costs and benelits of the generation alternatives. Besides the supplier of electricity, costs and benefits of the generating aliernatives to both consumers of electricity and the economy as a whole should be included in the analysis.

In Jordan's case, this is particularly important in comparing coal or heavy fuel oil generating alternatives with oil shale. Whether coal or heavy fuel oil is used, the fuel must be imported. This represents a significant foreign exchange drain which would not be the ease for the shale alternative. Therefore, viewing the problem strictly from the standpoint of the firm (JEA in this casc:) would not include one of the most significant benefits of the shale alternative to the economy as a whole - forcign exchange savings. Another tenefit of the shale option in comparison with altermatives using imported fucls which is not very easy to quantify is increased cnergy security. Easing reliance on imported soureses of energy - especially petroleum - in a politically fragile part of the world is a substantial benefit which is ver', difficult to gututify in a cost-benefit analysis. Finally, there are the macroeconomic effects of using the local labor force for the shate mining opcration. Employing Jordanian laborers will have a beneficial effect on national income.

Despite the caveats just presented, the sensitivity studies will be condiated at the level of JEA - the individual firm level. Besides problems with quantifying many of the costs and bencfits aceruing to electricity consumers and the economy as a whole, using a firm-level analysis facilitates comparison with other power generation alternatives which already have been studied. The Ayaba option, for cximple, hats undergone intense scrutiny by the World Bank. The IRR for this option has becu calculated under various inpul cost assumptions and can casily be compared with the results on the shale option. However, the net henefits of the shak option beyond JEA's level will be discussed in the final section of this chapter.

The results of financial and economic analyses are contingent on assumed input costs and revenue flows over the lifetime of the plant. Before proceding to the financial and economic results, it is important to consider individual inputs and their cost for producing power using oil shale. Each of these inputs will he considered in detail below. The next section discusses capilal expenditures required for each of the plant-size alternatives. Section 9.2 presents the O\&M expenses for each option, including fuel cost, other O\&M expenses for producing power, and the cost of disposing of the residual ash. The financial comparison and economic sensitivity results are presented and discussed in Sections 9.3 and 9.4, respectively. 


\subsection{CAPITAL EXPENDITURES}

Figure 9.1 presents a schematic for the flow of major inputs and outputs of the integrated shale-for-power system. The data in the figure are for a 50-MW plant, operating at a 75 percent capacity factor. ${ }^{4}$ The figure shows that 973,000 tonnes of raw shale will be mined, sent for processing (crushing), and delivered to the plant. The plant will produce $345.8 \mathrm{GWh}$ of electricity each year, of which $338.4 \mathrm{GWh}$ will be delivered to the transmission network and $7.4 \mathrm{gWh}$ will be used in the shale processing operation. Dry ash in the amount of 657,000 tonnes will be recovered from the plant. After welting, the ash will he 25 pereent larger by weight $(815,00)$ tonnes) and will be delivered to a holding site.

There are five broad functions involved in using oil shale for power generation in Jordan. They include:

1. mining the shale,

2. processing (or crushing) the shale,

3. producing power,

4. removing the residual ash, and, not shown in Figure 9.1,

5 . housing the employees.

Each of these functions requires the expenditure of capital..$^{5}$ In the present economic analysis, there are several ways to treat the functions. The Bechtel Group treated the entire shale-for-power problem as a vertically integrated activity, presuming the operator of the power plant would be involved in both oil shale mining and processing and residual ash removal. ${ }^{6}$ However, they separated the functions into four categories: (1) mining and processing, (2) the power block, (3) residual ash removal, and (4) community facilities or housing. For each of these categories of activity, estimated capital expenditures were provided and the unit cost of shate to the plant and the unit cost of ash removal were provided, which included the estimated O\&M costs of these activities. Thus, comparisons can be made of the unit cost of oil shale delivered to the plant with other fuels, such as coal and heavy fuel oil.

In actual practice, producing power from shale in Jordan may not be an integrated activity. It is possible that the mining activity could be contracted out, providing shale to the plant and disposing of the residual ash. ${ }^{7}$ In this case, the owner of the plant would be involved only in processing the shale and producing power.

In the ensuing economic analysis, the cost of fuel and residual ash disposal are treated as separate operating expenses for producing power. The only capital expenditures are for the plant itself. Thus, cost categories are capital expenditures on the plant itself and three categorics of operating expenses:

1. power production O\&M expenses, including water, labor, and the like,

2. the delivered cost of fuel (shale), and

3. ash removal.

\footnotetext{
4The capacity factor is defined as the ratio of net generation of a power plant and the theoretically possible amount of gencration. The latter is the nameplate capacity of the plant times 8,760 hours, the number of hours in a 36.5 -day year.

5 These five functions and associated capital expenditures subsume some oher very imporlant activilies. The water supply system for the power plant is included in producing power. Environmental costs are included in both the mining and ash removal portion of the project.

6The term integrated is used here technically wherein an enterprise manufactures a commodity and all inputs used in the commodity's production.

${ }^{7}$ Several bids from Jordanian concerns have already been received by the Natural Resources Authority of Jordan for mining the shale. However, it is questionable whether the bids are realistic. It does not seem that the miring interests properly understood the nature of the task. For example, residual ash disposal, internalizing the environmental costs, does not seern to have been included in the bids.
} 


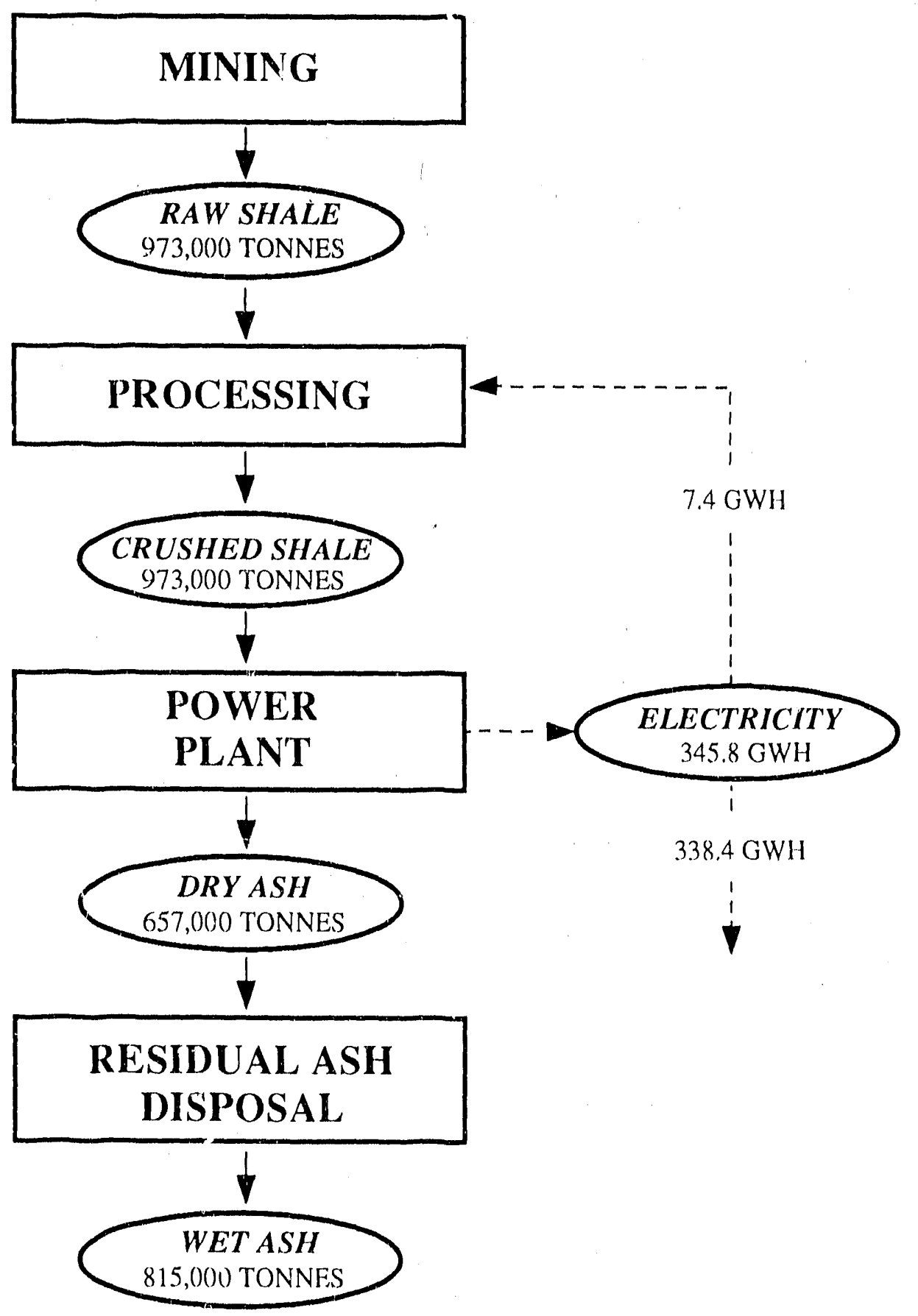


The remaining problem is the cost of housing. The location of the proposed shale plant is in a fairly remote area approximately $100 \mathrm{~km}$ south of the capital, Amman. There is some likelihood that housing facilitics would have to be constructed at the plant site to aceommodate both indigenous labor and expatriates and their families. The cost of constructing a "town" can be significant, depending on the type of living arrangements used for the workers.

As an example, living quarters for $7(0) \mathrm{cmployecs}$ at Shidiya, a remote phosphate mining site approximately $300 \mathrm{~km}$ south of Amman, are in the design stage. The total cost of the project is estimated to be 2 million JD (approximatcly $\$ 6$ million). The area encompasses appioximately 17,800 square meters with construction costs cstimated to be 90 JD per seluare meter, excluding the cost of iatrastructure (roads, water, and electricity). The cost of the infrastructure is estimated to be another $20(0,()()) \mathrm{JD}(\$ 60),(0)(0)$. The Shidiya site will accommodate only bachelors. It provides "bunkhouses" for four people, consisting of a kitchen, bath, and two bedrooms, two men to a room. Besides the living guarters for the workers and the infrastructure, a restaurant, a social club, a shopping area, health clinic and a guest house are inclu' '! in the total cost of 2 million JD.

In contrast to the Shidiya project, the cost of construction for the town built near the El Hasa mining site from 1983-1987 was considerably more expensive. Total cost wats estimaled at 173 JD per suluare meter, even though it is located much closer to Amman and, in comparison with the Shidiya site, is considerably more accessible to the Desert Highway, running north-south through Jordan. The reason for the difference in construetion cost is that the El Hasa site was constructed for families and, therefore, is much more elaborate. A total of 5() () houses were constructed for $3,()(X)$ persors, based on an average of 6 persons per household. Although the El Hasa site included the same type of social facilities built at Shidiya (restaurant, shopping area, and the like), they were much more elaborate and expansive. The El Hasa site included schools for 420 students and a sports center, including a sexecr field, two swimming pools, tennis courts, and a playground.

The phosphate mining company constructing these towns does not recoup its cost of construction from the inhabitants. The rent for a family living at the El Hasa site is $3.5 \mathrm{JD}$ (approximately $\$ 10.5()$ ) per month. Rather, the housing is provided as a perquisite to altract skilled labor to these remote areas. The company recoups the cost of construction by depreciating the "town" using a straight-line method, 5 percent per year over a 2()-year period. Thus, housing is teated as any other capital expenditure in determining the cost of the plant.

A complicating factor in determining the cost of housing for workers at the proposed oil shale-fueled power plant is that production at the El Hasa phosphate mining site is scheduled to be phased out during the next several years, with operations completely terminated in the mid- to late-1990)s. This scheduled termination date is well in advance of the anticipated completion of the power plant. Because of the close proximity of the El Hasa town site to the oil shale-fucled power platit (approximately $30 \mathrm{~km}$ ), it is possible that mining and power personnel could use at least a portion of the existing town site presently occupied by the El Hasa personnel, thereby mitigating the housing cost for the propesed shale plant(s). However, the expected number of cmployecs for the integrated power prociuction operation is significant. For the 20. MW plant, 185 pecople are expected to be employed, 75 of whom will be used in the mining/processing operation. For the 5()- and $4(x)$ MW plants, the numbers are 324 (16.3 in mining/processing) and 1,046 (396), respectively.

Another complicating factor is that some workers could live in Karak or Qatranch and commute to the mine by company bus, as is currently the case at the El Abïad mine.

In the sensitivity analysis below, we include the cost of housing as a direct cost of producing power at the Sultani site. Thus, the capital expenditures include the capital expense for providing housing for the workers,

\footnotetext{
8 While in Jordan, there secmed to be a bit of a lax controversy using this method. It seems thet the phosphate company was involved in a "litigation" or discussion with the government over the deduction of the depreciation for tax purposes.
} 
recognizing that a portion of the workers may be miners who are not part of the ownership of the plant. Table 9.1 provides the estimated cost of housing for the three plant sizes under consideration, along with their estimated capital costs, the Allowance for Funds Used During Construction, and the cost per kW of the three plants, including and excluding the cost of housing.

In the economic analysis that follows, the imputed capital charges are excluded from the analysis because they do not represent a cash flow item.9 Thus, the cost of the three plant sizes, including housing, which will be used in the economic analysis range from $\$ 70.4$ million for the $20 \mathrm{MW}$ plant to $\$ 111.4$ and $\$ 641.2$ million for the $50 \mathrm{MW}$ and $400 \mathrm{MW}$ options, respectively. On a dollars per $\mathrm{kW}$ basis, the $20 \mathrm{MW}$ plant is nearly double the amount for the $4(0) \mathrm{MW}$ option when the cost of housing is included.

Table 9.1 Capital expenditures, 20-, 50-, and 400. MW options $\left(\$ 10^{3}\right)$

\begin{tabular}{|c|c|c|c|}
\hline Categrory & $20 \mathrm{MW}$ & $50 \mathrm{MW}$ & $4(0) \mathrm{MW}$ \\
\hline Power Plant & 67,700 & 112,200 & $76(0,500)$ \\
\hline Housing & $10,00()$ & $15,(0)(0)$ & $45,(00)$ \\
\hline AFUDCa & $(7,30)(0)$ & $(15,800)$ & $(164,3()())$ \\
\hline Tolal & 70,400 & 111,400 & $6+1,200$ \\
\hline Cost/kW (without housing) & 3,385 & 2,244 & 1,901 \\
\hline Cost/kW (with housing) & 3,885 & 2,544 & $2,() 14$ \\
\hline
\end{tabular}

\subsection{OPERATION AND MAINTENANCE EXPENSES}

Given the conceptualization of the plant site presented in the previous section, there are three caltegories of O\&M expenses which enter into the sensitivity study: (1) the unit cost of oil shale, (2) the unil cost of disposing of the residual ash from the power plant, and (3) other O\&M expenses, including wages and salaries, water, and the like. Each of the three categories will be discussed below.

\subsubsection{Cost of Shale}

Table 9.2 summarizes the mining and processing capital and operating costs for the 2()-, 50)-, and 4()()-MW options, assuming the plants operate at a 75 percent capacity factor. The information presented in the lable summarizes the Bechtel Group's analysis for the three size alternatives. The capital cost represents the out-ofpocket expenditures for constructing the mining and processing facilitics, excluding the imputed amount of AFUDC. Those figures are provided in the second category of data in the table. The amount of AFUDC is smaller for the $50 / 50 \mathrm{D} / \mathrm{E}$ option because the cost of capital is only capitalized for the amount of debt - not the equity portion. The unit cost of providing shale to the plant is less under the $8(0 / 20 \mathrm{D} / \mathrm{E}$ option because of the

\footnotetext{
9AlUUDC or Interest During Construction (IDC) is an accounting construct which allows a firm to recoup the capital charges of investment projects with long construction lead times. The amount is reflected as income on the profil and loss statement offet by a corresponding charge to the cost of the plant. The amount is recouped through depreciation charges over the lifetime of the plane. In the economic analysis, we are working strictly on a cash basis and, therefore, the amounts for $\triangle F U D C$ are not considered in the construction expenditures for the plant.
} 
lower assumed cost of debt capital.

Table 9.2 Mining and processing costs, 20-, 50-, 400-MW options

\begin{tabular}{|c|c|c|c|}
\hline Catcgory & $20 \mathrm{MW}$ & $50 \mathrm{MW}$ & $400 \mathrm{MW}$ \\
\hline Capital Costa $\left(10^{3}\right.$ U.S.\$) & 25,335 & 31,923 & 162,816 \\
\hline \multicolumn{4}{|l|}{$A F U D C\left(10^{3}\right.$ U.S.\$) } \\
\hline $50 / 50 \mathrm{D} / \mathrm{E}^{b}$ & 2,534 & 3,192 & 24,423 \\
\hline $80 / 20 \mathrm{D} / \mathrm{E}$ & 4,054 & 5,108 & 39,075 \\
\hline \multicolumn{4}{|l|}{ Operating Costs (103 U.S. \$) } \\
\hline $50 / 50 \mathrm{D} / \mathrm{E}$ & 6,827 & 13,118 & 56,606 \\
\hline $80 / 20 \mathrm{D} / \mathrm{E}$ & 5,582 & 11,556 & 48,945 \\
\hline \multicolumn{4}{|l|}{ Unit Cost (U.S. \$/tonne) } \\
\hline $50 / 50 \mathrm{D} / \mathrm{E}$ & 17.50 & 13.48 & 7.76 \\
\hline $80 / 20 \mathrm{D} / \mathrm{E}$ & 14.31 & 11.88 & 6.84 \\
\hline Amount $\mathrm{c}^{\mathrm{C}}\left(10^{3}\right.$ tonnes $)$ & 390 & 973 & 7,783 \\
\hline
\end{tabular}

The table shows that there are significant economies in oil shale mining and processing. Under the 80/20, D/E option, the unit cost is only $\$ 6.84 /$ tonne for the 400 - MW option in comparison to $\$ 14.31 /$ tonne for the 2 )MW option. A similar result emerges for the 50/50 D/E ontion. The Bechtel Group study's design analysis was for the mining/processing operation to provide enough fuel for the plant operating at 100 perecnt capacity.

\subsubsection{Residual Ash Disposal}

Table 9.3 provides the same information for residual ash disposal costs as that provided for mining and processing costs in Table 9.2. Here, the unit cost for disposing of the residual shale declines for the 5()-MW case in comparison with the 20-MW case, but increases for the 400-MW case because of the amount of residual ash required for disposal.

\subsubsection{Other O\&M Expenses}

Table 9.4 presents other O\&M expenses for the three plant sizes and three capacity factors. In its analysis, the Bechtel Group divided other O\&M expenses into fixed and variable portions, but computed these expenses for the 75 percent capacity factor case onlv. To obtain the variable amounts for the 50 and 60 percent cases, O\&M expenses were changed to reflect different amounts of input. The fïxed portion of other O\&M expenses was not changed for the 50 percent and 60 percent cases. 
Table 9.3 Residual ash disposal costs, 20-, 50-, 400-MW options

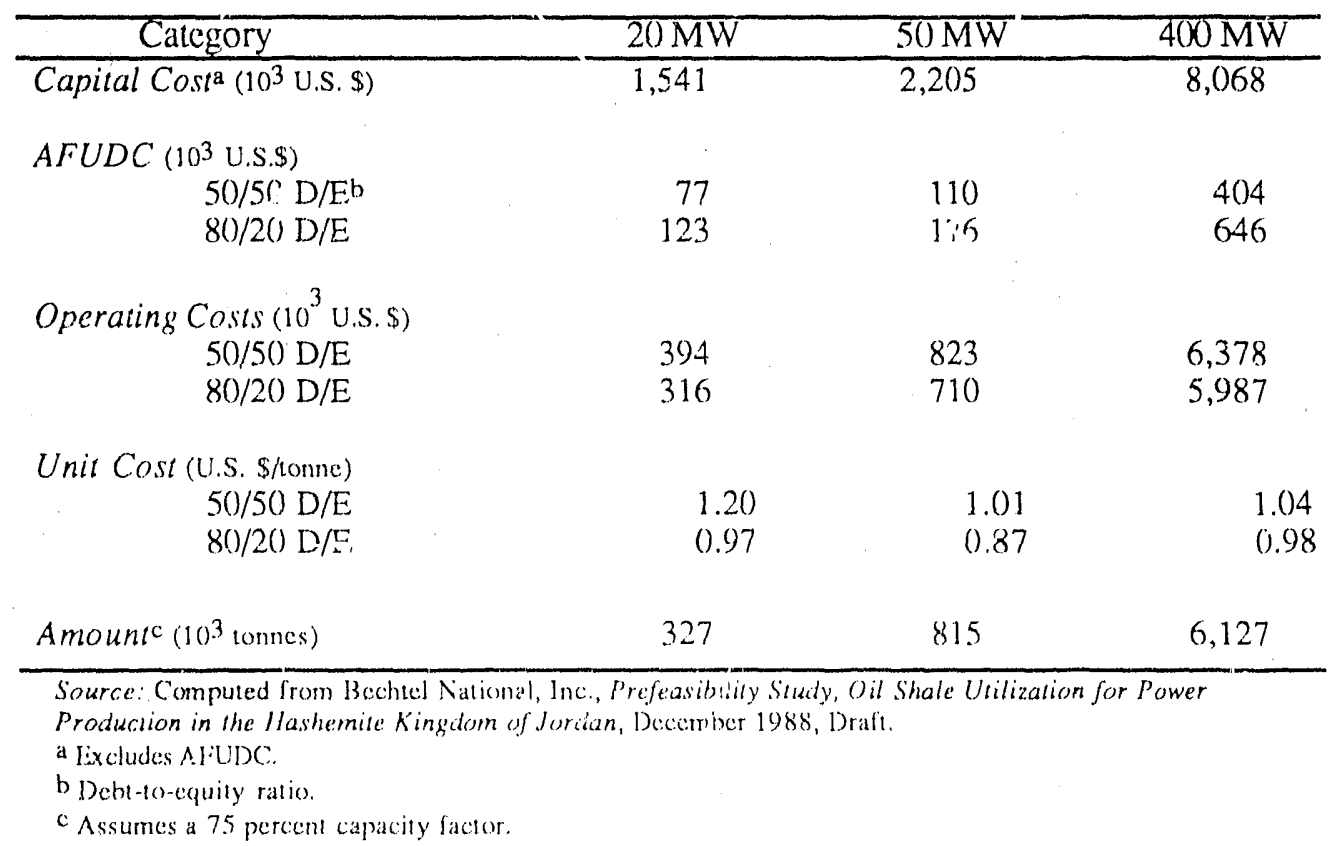

Table 9.4 Other O\&M expenses, unit cost by plant size and capacity factor $(\& / \mathrm{kWh})$

\begin{tabular}{cccc}
\hline Sizc & $50 \%$ & $6(1) \%$ & $75 \%$ \\
\hline $20 \mathrm{MW}$ & 2.15 & 1.83 & 1.50 \\
$50 \mathrm{MW}$ & 1.34 & 1.15 & 0.96 \\
$400 \mathrm{MW}$ & 0.87 & 0.76 & 0.65 \\
\hline
\end{tabular}

The table show's significant economies by increasing plant size For the 75 percent capacity factor case, other O\&M expenses were more than double on a cents per kilowatt-hour of generation basis for the 2()-MW in comparison with the 40()-MW plant. The 2()-MW plant was more than 50 percent larger in comparison with the 5()-MW for the 75 percent capacity factor case. Similar results were obtained for the other capacity factors.

\subsection{FINANCIAL ASPECTS OF THE SHALE ALTERNATIVE}

There are a number of competing alternatives for power generation in Jordan. Here, a financial comparison is made of several of the altematives. First, we consider the actual or ration of the $2 \times 130$-MW base-load thermal units at Aqaba (referred to as Aqaba I) during 1987. Second, 2()-MW, 5()-MW, and 40()-MW oil shale alternatives are considered. Finally, the 2 × 13()-MW deferred base-load units at Acjaba (known as Aqaba II) will be compared using coal as the alternative fucl.

Table 9.5 presents a summary of the comparison, providing capital cost $/ \mathrm{kW}$, total capital costs, fucl requirements, fuel costs, and the financial analysis on a $₫ / k$ Wh basis. The results are based on an assumed cost 
of capital of 15 percent for the shalc alternatives and 9 percent for the two Aqaba plants. 10 The assumed capacity factor is 75 percent. For Aqaba I, the fucl and O\&M costs are actual figures for an 11 -month period in 1987, using a 3:1, dollar:dinar exchange rate. The Aq̣aba II data are based on a World Bank study. The capital costs are derived from the World Bank study and the $\$ 53$ unit fucl cost is the c.i.f. price of quotations made to the Jordanian government for coal imports.

Table 9.5 Financial comparison of generating plant alternatives

\begin{tabular}{|c|c|c|c|c|c|}
\hline Category & Aljaba 1 & Shale & Shale & Shale & Aggaba 2 \\
\hline Capacity (MW) & 260 & 20) & 50) & $4(0)$ & 260 \\
\hline Cost $\left(\frac{3}{(k W}\right)$ & 931 & 3885 & 2544 & 2014 & 950 \\
\hline Capital Cost $\left(\$ 10^{6}\right)$ & 242 & 78 & 127 & 806 & 247 \\
\hline Gencration@75\% (GWh) & 1708 & 131 & 328 & 2628 & 1708 \\
\hline Fuel Needs $\left(10^{3}\right.$ tonnes/y) & Aclual & 390 & 973 & 7783 & 964 \\
\hline Fucl Cost (\$honnc) & Actual & 14.31 & 11.88 & 6.84 & 53.00 \\
\hline \multicolumn{6}{|l|}{ Comparative Cost ( $q / \mathrm{k} W \mathrm{~h})$} \\
\hline Fucl & 2.61 & 4.25 & 3.52 & 2.03 & 2.99 \\
\hline O\&M & 0.98 & 1.50 & 0.96 & 0.65 & 0.90 \\
\hline Capital & $1.28 \mathrm{a}$ & $8.87^{b}$ & $5.81 \mathrm{~b}$ & $4.600^{\mathrm{b}}$ & $1.30 \mathrm{a}$ \\
\hline Total & 4.87 & 14.62. & 10.29 & 7.28 & 5.19 \\
\hline
\end{tabular}

a Assumes capital cost of 9 percent per annum.

b Assumes capital cost of 15 percent per annum.

The results show that, from a financial standpoint, the existing $2 \times 13$ ()-MW units at Aqaba I are the least costly on a cents per kWh basis, with the proposed coal plant at Acjaba II the second best financial cost option. The 40()$-\mathrm{MW}$ shale option is more than $2 \notin / \mathrm{kWh}$ more costly to run than the proposed plant at Aqaba.

In a capital budgeting problem, simple innancial costs do not provide a true basis of comparison of competing alternatives. Financial costs are merely indicative. An economic analysis of the alternatives is required. We turn to this analysis in the next section.

\subsection{ECONOMIC ANALYSIS OF THE SHALE ALTERNATIVE}

\subsubsection{Sensitivity Analysis at JEA's Level}

Four variables will be perturbed in the sensilivity analysis:

1. Average revenue of JEA's sales. In 1987, the average revenue accruing to JEA for all of its sales was 20.7 fils per $\mathrm{kWh}$ of electricity sold, which translates into $6.0 \% \mathrm{kWh}$, assuming a 3

\footnotetext{
10 The difference in the cost of capital for the Aqaba plants and the shale altematives is attributable to the assumed capital structure for the plants. The Aqaba I and II plants are financed using debt exclusively. It is assumed that the shale altematives will be firanced party by equit?, which has gesncigted with it . higher return than debt financing available to JEA and the Jordanian government.
} 
U.S. dollar per Jordanian Dinar exchange rate.11 A tariff change was not made in 1988.12 Therefore, in the sensitivity studies which follow, the base revenue is assumed to be the same as in 1987.13 To show what effect a tariff increase wo!ld have on the cconomics of the pronosed plant(s), average revenues were increased 25 percent to $7.5 \mathrm{c} / \mathrm{kWh}$ and 50 percent to $9.0 \mathrm{k} / \mathrm{kWh}$ in the sensitivity studics.

2. acity Factor. The Bechtel Group's analysis used a 75 percent annual capacity factor, assuming that the proposed oil shale plant would be a base-load unit. To sec what effect lower annual running rates would have on the economics of the plant(s) - due cither to maintenance and materials handling probiems, or insufficient power needs - the IRR for 50 and 60 percent running rates were computed in addition to the 75 percent case.

3. Debt/Equity Ratio. The Bechtel Group's analysis assumed two different debt/equity ratios for the mining/processung function and the ash disposal function: 50/50 and 8(2/20. The latter results in a lower average unit cost because of the assumption that the cost of debt is less than that of equity. These input costs were summarized in Tables 9.2 and 9.3 , respectively. Sensitivi.y analyses were conducted using both of these input assumptions.

4. Capital Expenditures. In their estimate of capital expenditures for the 2()-, 5()-, and 40()-MW! options, the Bechicl Group provided one estimate of capital expenditures. These estimates for the three plant sizes will be considered the base capital expenditure scenarios in this study (noted Base). To include uncertainty in the analysis, two other groups of scenarios were considered. ${ }^{14}$ Relying on a commonly used practice, the capitil expenditures in the Base scenario were changed by 125 jercent [noted Base(0.75) and Base(1.25)] in the first group. In the second group of scencrios, the base case capital expenditures were increased by 50 percent ! Base(1.50)] and $1(0)$ perent $\mid$ Base $(2 .(0)) \mid$ to reflect uncertantics in both the Jordanian exchange rate and the cost of constr" ting the plant in a foreign environment. This will be discussed more fully below. ${ }^{15}$ The time struary of capital expenditures was obtained from the Bechtel Group's study. For the 20- and 50-MW options, the expenditures were made over a 31 -month period. For the 4()()-MW option, It was over a 48 -month period with each of the $10(0)-\mathrm{MW}$ units beginning construction six months after the previous one started.

The discount rate in all of the analyses is 9 percent per annum, reflecting the opportunity cost of capital to JEA. The O\&M expenses per $\mathrm{kW} / \mathrm{h}$ of gereration under the three different capacity factors for the three plant sizes were provided in Table 9.4 above. In the Bechtel Group's study, the amount of oil sinate needed, spent ash to be disposed of, and net electricity generation for the three plant sizes at a 75 pereent capacity factor were provided. These amounts are also needed for the 60) and 50 pereent scenarios. That information is provided in Table 9.6.

\footnotetext{
11 There are 1,00(0) fils in each J,rdanian Dinar.

12 As discussed in Chapter 3, a tariff study was conducted in early 1988, but tariffs were not changed based on this study. The last tariff change was in June 1986.

13 Using 1987 data may ov'rstate the amount. Recently, electricity prices were lowered for some customer classes as part if an austerity program announced by King 11 ussein on November 6, 1988. See Wall Street Journal and New York Times, Novemiber 7. 1988.

14 The effex:s of uncertainty can also be included by increasing the discount rate. We choose here to change the amount of capital expenditures.

$15 \mathrm{As}$ is the case with all of the scenarios, the purpose for including these two other capital expenditure scenarios in the study is not to speculate on the likelihood of their occurrence. Probabilities are not assigned to any of the input costs or revenues accruing to

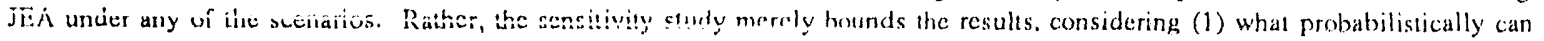
occur (such as lower running rates and higher capital expenditures) and (2) what must occur to improve the economic altractiveness of the shale altemative (such as higher rumning rates and increased average revenues). It is left to individual readers to speculate on the likelihood of each scenario.
} 
Table 9.6 Physical quantities, alternative scenarios (by plant slze and capacity factor)

\begin{tabular}{|c|c|c|c|}
\hline $\begin{array}{l}\text { Size/Canacity } \\
\text { Factor } \\
\end{array}$ & $\begin{array}{c}\text { Oil Shale } \\
\left(10^{3} \text { tonnes }\right) \\
\end{array}$ & $\begin{array}{l}\text { Spent Ash } \\
\left(10^{3} \text { tonnes }\right)\end{array}$ & $\begin{array}{l}\text { Generation } \\
(\mathrm{GWh})\end{array}$ \\
\hline \multicolumn{4}{|l|}{$20 \mathrm{MW}$} \\
\hline 50 percent & 260.0 & 218.0 & 89.8 \\
\hline 60 percent & 312.0 & 261.6 & 107.7 \\
\hline 75 percent & 390.0 & 327.0 & 134.7 \\
\hline \multicolumn{4}{|l|}{$50 . M W$} \\
\hline 50 pcrcent & 648.7 & 543.3 & 225.6 \\
\hline 60 percent & 778.4 & 652.0 & 270.7 \\
\hline 75 percent & 973.0 & 815.0 & 338.4 \\
\hline \multicolumn{4}{|l|}{$400 \mathrm{MW}$} \\
\hline 50 percent & $5,188.7$ & $4,084.7$ & $1,752.0$ \\
\hline 60 percent & $6,226.4$ & $4,901.6$ & $2,102.4$ \\
\hline 75 percent & 7.783 .0 & $6,127.0$ & $2,628.0$ \\
\hline
\end{tabular}

Source: Computed from Bechtel National, Inc., Prefeasibility Study, Oil Shale Utilization for Power Production in the Hashemite Kingdom of Jordan, December 1988, Draft.

\subsubsection{Base case capital expenditure scenario}

The results for the base case capital expenditure scenario are presented in Table 9.7. Entries with a "." reflect a scenario with an internal rate of return less than zero. The table shows that the 20-MW option is not economically attractive. This plant size has a return greater than zero under only the most favorable conditions: a high capacity factor, low input costs (an 80/20 debv/equity ratio for both mining and processing costs and ash disposal), and a very favorable average revenue amount $(9.9 \mathrm{~g} / \mathrm{kWh}$, a 50 percent increase over the amnunt realized by JEA in 1987).

Under IEA's current tariff structure $(6.0 \varnothing / \mathrm{kWh})$, the 50-MW alternative is not economically attractive, either. None of the input scenarios resulted in an IRR greater than zero assuming this tariff structure tor the 50-MW option. The IRR for the 400-MW plant under the current tariff structure approaches or exceeds JEA's opportunity cost of capital ( 9 percent) assuming a 75 percent capacity factor ( 8.56 and 9.77 percent under the $50 / 50$ and $80 / 20$ debt/equity scenarios, respectively). Assumed lower annual running rates result in significantly lower returns, dropping to 3.24 percent under the most unfavorable assumed conditions.

'The returns for the 50-MW option do not exceed JEA's opportunity cost of capital even if a 25 percent increase in tariffs is assumed (from $6.0 \mathrm{~d} / \mathrm{kWh}$ to $7.5 \mathrm{k} / \mathrm{kWh}$ ). Only under the most favorable revenue and running rate assumptions do the 50-MW returns exceed 9 percent. Assuming the same 25 percent increase in tariff levels to $7.5 \% / \mathrm{kWh}$, the simulated returns for the 400 -MW option exceed 9 percent under both 75 percent and 60 percent capacity factors. They even approach that level under an assumed 50 percent runt ing rale. 
Table 9.7 Sensitivity results, alternative scenarios, base capital expenditures, 20-, 50-, and 400-MW plant options

\begin{tabular}{|c|c|c|c|c|c|}
\hline \multirow{2}{*}{$\begin{array}{l}\text { Capacity } \\
\text { Factor }^{\mathrm{a}} \\
(\%)\end{array}$} & \multirow{2}{*}{$\begin{array}{l}\text { Average } \\
\text { Priceb } \\
(q / k W h) \\
\end{array}$} & \multirow{2}{*}{$\begin{array}{c}\text { Debt } \\
\text { Equityc } \\
(\%) \\
\end{array}$} & \multicolumn{3}{|c|}{ Internal Rate of Returnd } \\
\hline & & & $20 \mathrm{MW}$ & $50 \mathrm{MW}$ & $400 \mathrm{MW}$ \\
\hline 75 & 9.0 & $50 / 50$ & 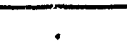 & 9.33 & 19.04 \\
\hline 75 & 7.5 & $50 / 50$ & . & 4.30 & 14.16 \\
\hline 75 & 6.0 & $50 / 50$ & . & . & 8.56 \\
\hline 75 & 9.0 & $80 / 20$ & 1.75 & 10.80 & 19.97 \\
\hline 75 & 7.5 & $80 / 20$ & . & 6.15 & 15.18 \\
\hline 75 & 6.) & $80 / 20$ & . & . & 9.77 \\
\hline 60 & 9.0 & $50 / 50$ & . & 6.28 & 14.80 \\
\hline 60 & 7.5 & $50 / 50$ & . & 1.55 & 10.55 \\
\hline 60 & 6.0 & $50 / 50$ & . & & 5.55 \\
\hline 60) & 9.0 & $80 / 20$ & . & 7.62 & 15.61 \\
\hline 60 & 7.5 & $80 / 20$ & . & 3.32 & 11.46 \\
\hline 6) & 6.0 & $80 / 20$ & . & & 6.66 \\
\hline 50 & 9.0 & $50 / 50$ & . & 3.93 & 11.72 \\
\hline 50 & 7.5 & $50 / 50$ & . & . & 7.89 \\
\hline 50 & 6.0 & $50 / 50$ & . & & 3.24 \\
\hline 50 & 9.0 & $80 / 20$ & . & 5.21 & 12.45 \\
\hline 50 & 7.5 & $80 / 20$ & . & 1.09 & 8.72 \\
\hline 50 & 6.0 & $80 / 20$ & & & 4.30 \\
\hline
\end{tabular}

The capacity factor is the ratio of total net generation from a plant to the theoretical maximum amount that the plant can generate in a year. The latter is calculated as the product of nameplate capacity and the number of hours in a year $(8,760$ in a 365 -day year $)$.

6 Average price is total revenues realized divided by total sales.

c Debi/equity is the assumed capitalization for mining and processing and residual ash disposal operations. They were discussed at length in Section 9.2.

$\mathrm{d} A$ "." signifies that the retum is less than zero

To summarize the base capital expenditure scenario, relurns for the 4())-MW option exceed JEA's opportunity cost of capital in 11 of the 18 scenarios and approach it in two others. The 50-MW option excecds JEA's 9 pereent opportunity cost of capital under the two most favorable sets of assumptions: high running rales and high average revenue per $\mathrm{kWh}$ of electricity sold. Under the pricing schedule that existed in 1987 (an average revenue of $6.0 \notin / \mathrm{kWh}$ ), the IRR for the 5()-MW option never exceeds zcro.

\subsubsection{Plus/minus 25 Percent capital expenditure scenarios}

Tables 9.8 and 9.9 present sensitivity results for the Base( $(0.75)$ and Base(1.25) capital expenditure scenarios, respectively, reflecting a 25 percent decrease and increase in the base case scenario. The 20-MW plant is not an economically attractive option even if the capilal expenditures are reduced by 25 percent (Table 9.8). Internal rates of return are greater than zcro in only threc cases, but do not approach JEA's opportunity cost of capital.

As was the case with the base scenario, the 50-MW alternative is not an economically attractive option under JEA's current tariff level $(6.0 \$ / \mathrm{kWh})$ assuming a 25 percent reduction in capital expenditures (Table 9.8$)$. The IRR is greater than zero in only one case under this tariff level. Assuming a 2.5 percent increase in the tariff level in the Base(0.75) scenario (Table 9.8), the return for the 5()-MW option exceeds 9 percent only under the most favorable situation: 75 percent capacity factor and $80 / 20 \mathrm{dcb} / \mathrm{cquity}$ ratio for the mining/processing and ash disposal functions. The 50-MW option is cconomically unatuactive in all scenarios where capital expenditures were increased by 25 percen [ Base(1.25) in Table 9.9]. The only case in which JEA's opportunity 
cost of capital is approached (8.24 per: $2 n t$ in Table 9.9) is the one which assumes a 50 percent increase in the average tariff level from what currently exists $(6.0$ to $9 .(0 \mathrm{k} / \mathrm{kWh})$, a 7.5 percent capacity factor, and a 80/20 debt/equity ratio for the mining/processing and ash renoval functions.

The results for the 400)-MW simulations under the Base(0.75) scenario (Table 9.8) show that returns approach or exceed 9 percent under all scenarios with the exception of the $6.04 / \mathrm{kWh}$ and 50 percent capacity factor assumptions. However, increasing capital expenditures by 25 perent from the base case [Base(1.25) scenario in Table 9.9] results in returns less than 9 percent under all cases in which average revenues are assumed to be 6.0 $/ \mathrm{kWh}$. Increasing average revenues by 25 percent to $7.5 \mathrm{~d} / \mathrm{kWh}$ results in returns approaching or exceeding 9 percent in the 60 and 75 pereent running rate scenarios.

Table 9.8 Sensitivity results, alternative scenarios, base $(0.75)$ capital expenditures, 20-, 50-, and 400-MW plant options

\begin{tabular}{|c|c|c|c|c|c|}
\hline \multirow{2}{*}{$\begin{array}{c}\text { Capacity } \\
\text { Factora } \\
(\%)\end{array}$} & \multirow{2}{*}{$\begin{array}{l}\text { Average } \\
\text { Priceb } \\
(\notin / k W h) \\
\end{array}$} & \multirow{2}{*}{$\begin{array}{c}\text { Debl/ } \\
\text { Equilyc } \\
(\%) \\
\end{array}$} & \multicolumn{3}{|c|}{ Internal Rate of Returnd } \\
\hline & & & 2() MW & 50) MW & $4(0) \mathrm{MW}$ \\
\hline 75 & 9.0 & $50 / 50$ & 0.42 & 12.89 & 24.63 \\
\hline 75 & 7.5 & $50 / 50$ & . & 7.04 & 18.68 \\
\hline 75 & 6.0 & $50 / 50$ & . & 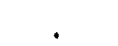 & 11.97 \\
\hline 75 & 9.0 & $80 / 20$ & 4.15 & 14.63 & 25.77 \\
\hline 75 & 7.5 & $80 / 20$ & . & 9.16 & 19.92 \\
\hline 75 & 6.0 & $80 / 20$ & . & 1.98 & 13.41 \\
\hline 60) & 9.0 & $50 / 50$ & . & 9.31 & 19.46 \\
\hline 60 & 7.5 & $50 / 50$ & . & 3.92 & 14.35 \\
\hline 60 & 6.0 & $50 / 50$ & . & • & 8.46 \\
\hline 60 & 9.0 & $80 / 20$ & 0.81 & 10.88 & 20.44 \\
\hline 60 & 7.5 & $80 / 20$ & . & 5.92 & 15.43 \\
\hline 60 & 6.0 & $80 / 20$ & . & . & 9.75 \\
\hline 50 & $9 .()$ & $50 / 50$ & . & 6.62 & 15.74 \\
\hline 50 & 7.5 & $5(0 / 50)$ & . & 1.43 & 11.18 \\
\hline 50 & 6.0 & 5()$/ 50$ & . & • & 5.79 \\
\hline 50 & 9.0 & $80 / 20$ & . & 8.08 & 16.62 \\
\hline 50 & 7.5 & $80 / 20$ & . & 3.40 & 12.17 \\
\hline 50 & 6.0 & 8()$/ 20$ & & & 7.01 \\
\hline
\end{tabular}

a The capacity factor is the ratio of total net generation from a plant to the theoretical maximum amoun that the plant can generate in a year. 'The later is calculated as the product of nameplate capacity and the number of hours in a year $(8,760)$ in a 365 -day year).

b Average price is total revenues realized divided by total sales.

c Deb//equity is the assumed capitalization for mining and processing and residual ash disposal operations. 'They were discussed at length in Section 9.2.

$d_{A} " . "$ signifies that the retum is less than zero.

\subsubsection{Higher capital expenditure scenarios}

Estimates of capital expenditures for power plants are notoriously uncertain. In the present case, two factors are especially important. First, the plant will be built in a developing country. Second, the forcign exchange costs are uncertain. Most recently, the Jordanian Dinar has been depreciating in international exchange markets, increasing the cost of importing matcrials for constructing power plants. On December 31, 1987, the Jordanian Dinar was worth $\$ 3.04$. The exchange rate stayed fairly stable during the first third of 1988 , equalling $\$ 2.95$ at 
the end of April 1988. However, since then it has steadily declined to the point where on December 15, 1988 it was $\$ 2.13 .16$ The figures for capital expenditures in this study are based on a mid-1988 exchange value of $\$ 3.00$ ) per Jordanian Dinar.

To provide for exchange rate uncertainty and other contingencies associated with constructing power plants in Jordan, two other scenarios were examined, assuming that the capital expenditures provided in the Bechtel Group's study were 50 percent higher (the Base(1.50) scenario) and were higher by a factor of two (the Base(2.00) scenario). All of the other input assumptions used in the base case scenario (Table 9.7) are the same. The results of the two high capital expenditure scenarios are presented in Tables 9.10 and 9.11.

As would be expected from the results of the other three scenarios, the 20-MW option is not economically attractive under the two high capital expenditure scenarios (Tables 10 and 11). For the 5()-MW option in the Base (1.50) scenario, the IRR does not exced JEA's opportunity cost of capital (9 percent) in any of the sensitivity runs. ? i results for the 400-MW option are a little more favorable. Assuming a 75 percent annual running rate, the $1 R R$ does not exceed JEA's cost of capilal under the tariff structure in existence in 1987 $(6 \mathrm{k} / \mathrm{kWh})$. However, by increasing the tariff level by $2.5 \mathrm{percent} t 07.5 \mathrm{e} / \mathrm{kWh}$ and 50 percent $109.0 \mathrm{e} / \mathrm{k}$ Wh under the 75 percent capacity factor case, the IRR exceeds 9 percent assuming both $50 / 50$ and 80/20 debtequity ratios for the mining and residual ash dispossal operations. Assuming lower capacity factors for the 40)-MW option, the results deteriorate. The IRR exceds 9 percent only under the $6(0)$ percent running rate scenario when the average tariff level is assumed to $b e 9 \notin / \mathrm{kWh}$.

The results for the Base(2.()) scenario are presented in Table 9.11 The IRR for the 4(K)-MW option exceeds JEA's opportunity cost of capital (9 percent) in the two most latvorable scenarios: a 75 perent capacity factor with an average revenue of $9.0 \% / \mathrm{kW}$ h. The only cases in which the IRR for the $4(0)-\mathrm{MW}$ option excecds zero under the tariff structure in existence in $1987(6 \notin / \mathrm{kWh})$ are the oncs assuming a 75 percent capacity factor. The 5()-MW option is not cconomically attractive under any of the input assumptions.

\subsubsection{A closer look at the 50-MW option}

Table 9.12 summarizes the results of Tables 9.7 through 9.11 for the 50)-MW option. Several comments are in order. First, the 5()-MW option is not cconomically altractive under the current tariff structure of JEA under all scenarios. An average revenue of $6 .(6) / \mathrm{k}$ Wh is not enough to generate an IRR greater than zero under any of the scenarios except onc. Second, increasing average revenues by 25 percent to $7.5 \mathrm{k} / \mathrm{kWh}$ results in a relurn greater than 9 percent in only one case in which capital expenditures are 25 percent less than the base case, the running rate is high, and the mining/processing and ash disposial operations are assumed to be capitalized on a 80/20 debu/equity basis. Third, increasing average revenue by 50 percent to $9 \mathrm{k} / \mathrm{kWh}$ leads to significantly better results. Under this case, the returns are greater than $z$ cero for all cases ass ning 60 and 75 percent rumning rates and are greater than 9 percent in cases in which capilal expenditures are assumed to be relatively low (Base(0.75) and Base scenarios). However, the table suggests that even under this most optimistic assumption on the level of tariffs, the economic results are very sensitive to the amount of assumed capital expenditures. And, the recent reduction in electricity latrifts in Jordan as part of an economic austerity program does not portend well for increases in clectricity tariffs, at least in the near future.

\footnotetext{
16'The latter amount is from the Wall Street Journal, December 16, 1988. Jarlier exchange rates are from Intemational Monetary Fund, International Financial Statistics, XL(9), Scptember 1988.
} 
Table 9.9 Sensitivity results, alternative scenarios, base(1.25) capital expenditures $20 \cdot, 50 \cdot$, and $400-\mathrm{MW}$ plant options

\begin{tabular}{cccccc}
\hline Capacity & Average & Debu & \multicolumn{3}{c}{ Internal Rate of Returnd } \\
\cline { 6 - 6 } $\begin{array}{c}\text { Factora } \\
(\%)\end{array}$ & $\begin{array}{c}\text { Price } \\
(\notin / \mathrm{kWh})\end{array}$ & $\begin{array}{c}\text { Equityc } \\
(\%)\end{array}$ & $20 \mathrm{MW}$ & $50 \mathrm{MW}$ & $400 \mathrm{MW}$ \\
\hline 75 & 9.0 & $50 / 50$ &. & 6.94 & 15.41 \\
75 & 7.5 & $50 / 50$ &. & 2.41 & 11.18 \\
75 & 6.0 & $50 / 50$ &. &. & 6.26 \\
75 & 9.0 & $80 / 20$ & 0.07 & 8.24 & 16.20 \\
75 & 7.5 & $80 / 20$ &. & 4.08 & 12.07 \\
75 & 6.0 & $80 / 20$ &. &. & 7.33 \\
60 & 9.0 & $50 / 50$ &. & 4.20 & 11.74 \\
60 & 7.5 & $50 / 50$ &. &. & 8.03 \\
60 & 6.0 & $50 / 50$ &. &. & 3.57 \\
60 & 9.0 & $80 / 20$ &. & 5.41 & 12.44 \\
60 & 7.5 & $80 / 20$ &. & 1.51 & 8.82 \\
60 & 6.0 & $80 / 20$ &. &. & 4.57 \\
50 & 9.0 & $50 / 50$ &. & 2.07 & 9.05 \\
50 & 7.5 & $50 / 50$ &. &. & 5.66 \\
50 & 6.0 & $50 / 50$ &. &. & 1.46 \\
50 & 9.0 & $80 / 20$ &. & 3.23 & 9.69 \\
50 & 7.5 & $80 / 20$ &. &. & 6.40 \\
50 & 6.0 & $80 / 20$ &. &. & 2.43 \\
\hline
\end{tabular}

a The capacity factor is the ratio of total net generation from a plant to the theorctical maximum amount that the plant can generate in a year. 'The latter is calculated as the product of nameplate capacity and the number of hours in a year $(8,760$ in a 365 -day year).

b Average price is total revenues realized divided by total sules.

'Debu/equity is the assumed capitalization for mining and processing and residual ash disposal operations. They were discussed at length in Section 9.2.

d A "." signifies that the retum is less than zero.

\subsubsection{Beyond JEA's Level}

The sensitivity study conducted in this report was taken at the individual firm level, that of JEA. There are three important extra-firm benefits - benefits that accrue to the economy or society as a whole - that must also be considered when evaluating the oil shale for power option. One of the most important is the foreign exchange savings resulting from using indigenous oil shale in comparison to importing petrolcum or coal. Imported petrolcum has been a significant drain on foreign exchange since the international petroleum shocks in the 1970s. Second, mining and processing the oil shale and disposing of the residual ash in comparison with importing coal and/or petroleum will have a significant net impact on employment in the country. The expected number of employees for the integrated operation is significant. For the 20-MW plant, 185 people are expected to be employed, 75 of whom will be used in the miningiprocessing operation. For the 50)- and 4())MW plants, the numbers are 324 (163 in mining/processing) and 1,046 (396), respectively. Finally, there is an energy security benefit to Jordan in terms of using domestic energy in comparison with importing petrolcum. 
Table 9.10 Sensitivity results, alternative scenarios, base(1.50) capital expenditures, 20-, 50-, and 400-MW plant options

\begin{tabular}{|c|c|c|c|c|c|}
\hline \multirow{2}{*}{$\begin{array}{l}\text { Capacity } \\
\text { Factora }^{\mathrm{a}} \\
(\%)\end{array}$} & \multirow{2}{*}{$\begin{array}{l}\text { Average } \\
\text { Priceb } \\
(\phi / k W h) \\
\end{array}$} & \multirow{2}{*}{$\begin{array}{l}\text { Debu } \\
\text { Equityc } \\
(\%)\end{array}$} & \multicolumn{3}{|c|}{ Internal Rate of Returnd } \\
\hline & & & $20 \mathrm{MW}$ & $50 \mathrm{MW}$ & $400 \mathrm{MW}$ \\
\hline 75 & 9.0 & 5()$/ 50$ & 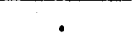 & 5.17 & 12.81 \\
\hline 75 & 7.5 & $50 / 50$ & . & 0.98 & 9.03 \\
\hline 75 & 6.0 & $50 / 50$ & . & & 4.56 \\
\hline 75 & 9.0 & $80 / 20$ & . & 6.36 & 13.52 \\
\hline 75 & 7.5 & $80 / 20$ & . & 2.54 & 9.83 \\
\hline 75 & 6.0 & $80 / 20$ & . & 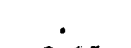 & 5.54 \\
\hline 60$)$ & 9.0 & $50 / 50$ & . & 2.65 & 9.53 \\
\hline 60$)$ & 7.5 & $50 / 50$ & . & . & 6.18 \\
\hline 60$)$ & 6.0 & $50 / 50$ & 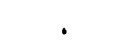 & & 2.08 \\
\hline 6) & 9.0 & $80 / 20$ & . & 3.76 & 10.16 \\
\hline 60$)$ & 7.5 & $80 / 20$ & . & 0.14 & 6.90 \\
\hline 60 & 6.0 & $8(0 / 20)$ & 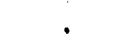 & & 3.00 \\
\hline 50 & 9.0 & 5()$/ 50$ & . & 0.67 & 7.11 \\
\hline 50 & 7.5 & $50 / 50$ & . & . & 4.01 \\
\hline 50 & 6.0 & $50 / 50$ & 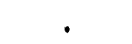 & 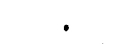 & 0.12 \\
\hline 50 & 9.0 & $80 / 20$ & . & 1.75 & 7.69 \\
\hline 50 & 7.5 & $80 / 20$ & 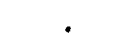 & 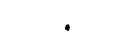 & 4.69 \\
\hline 50) & 6.0 & $8(1) / 20$ & & & 1.02 \\
\hline
\end{tabular}

a The capacity factor is the ratio of total net generation from a plant to the theoretical maximum amount that the plant can generate in a year. The latter is calculated as the product of nameplate capacity and the number of hours in a year $(8,760$ in a 365 -day year)

b Average price is tolal revenues realized divided by total sales.

c Debt/equity is the assumed capitalization for mining and processing and residual ash disposal operations. They were discussed at length in Section 9.2.

d $A$ ". signifies that the return is Iess than zero. 
Table 9.11 Sensitivity results, alternate scenarios, base(2.00) capital expenditures, 20, 50, and 4(0) MW plant options

\begin{tabular}{|c|c|c|c|c|c|}
\hline \multirow{2}{*}{$\begin{array}{l}\text { Capacity } \\
\text { Factora } \\
(\%)\end{array}$} & \multirow{2}{*}{$\begin{array}{l}\text { Average } \\
\text { Priceb } \\
\left(\left(\phi / \mathrm{kWh}^{2}\right)\right.\end{array}$} & \multirow{2}{*}{$\begin{array}{c}\text { Debl } \\
\text { Equilyc } \\
(\%)\end{array}$} & \multicolumn{3}{|c|}{ Internal Rate of Returnd } \\
\hline & & & $20 \mathrm{MW}$ & $50 \mathrm{MW}$ & $400 \mathrm{MW}$ \\
\hline 75 & 9.0 & $50 / 50$ & • & 2.66 & 9.26 \\
\hline 75 & 7.5 & $50 / 50$ & , & . & 6.05 \\
\hline 75 & 6.0 & $50 / 50$ & . & & 2.15 \\
\hline 75 & 9.0 & $80 / 20$ & . & 3.71 & 9.86 \\
\hline 75 & 7.5 & $80 / 20$ & . & 0.31 & 6.73 \\
\hline 75 & 6.0 & $80 / 20$ & . & & 3.02 \\
\hline 60 & 9.0 & $50 / 50$ & 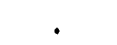 & (0.41 & 6.48 \\
\hline 60$)$ & 7.5 & $50 / 50$ & . & . & 3.57 \\
\hline 60 & 6.0 & $50 / 50$ & . & . & \\
\hline 60 & 9.0 & $80 / 20$ & . & 1.41 & 7.02 \\
\hline 6() & 7.5 & $80 / 20$ & . & . & 4.20 \\
\hline 6) & 6.0 & $80 / 20$ & . & . & 0.77 \\
\hline 50 & 9.0 & $50 / 50$ & . & . & 4.39 \\
\hline 50 & 7.5 & $50 / 50$ & . & . & 1.67 \\
\hline 50 & 6.0 & $50 / 50$ & . & . & \\
\hline 50 & 9.0 & $80 / 20$ & 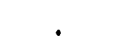 & . & 4.89 \\
\hline 50 & 7.5 & $80 / 20$ & . & . & 2.27 \\
\hline 50 & 6.0 & $80 / 20$ & & & \\
\hline
\end{tabular}

a The capacity factor is the ratio of total net generation from a plant to the theoretical maximum amount that the plant can generate in a year. The latter is calculated as the product of nameplate capacity and the number of hours in a year $(8,760$ in a 365 -day year).

b Average price is total revenues realized divided by total sales.

c Debu/equity is the assurned capitalization for mining and processing and residual ash disposal operations. They were discussed at length in Section 9.2 .

$\mathrm{d} A$ "." signifies that the retum is less than zero.

The premium that the country places on this difficult-to-quantify, extra-firm benefit - and the foreign exchange and employment benefits - may determine if the plant will be built in the case of it appearing to be economically unattractive from the standpoint of the electricity authority. 
Table 9.12 Summary of sensitivity results, 50-MW plant (percentages)

\begin{tabular}{|c|c|c|c|c|c|c|}
\hline \multirow{3}{*}{$\begin{array}{l}\text { Capital Expenditures } \\
\text { Capacity Factor }\end{array}$} & \multicolumn{6}{|c|}{ Average Revenue, Debt/Eguily Ratio } \\
\hline & \multicolumn{2}{|c|}{$6.04 / \mathrm{kWh}$} & \multicolumn{2}{|c|}{$7.5 \notin / \mathrm{kWh}$} & \multicolumn{2}{|c|}{$9.04 / \mathrm{kWh}$} \\
\hline & $50 \%$ & $80 \%$ & $50 \%$ & $80 \%$ & $50 \%$ & $80 \%$ \\
\hline \multicolumn{7}{|l|}{ Base(0.75) Scenario } \\
\hline 50 percent & . & . & 1.43 & 3.40 & 6.62 & 8.08 \\
\hline 60 percent & . & . & 3.92 & 5.92 & 9.31 & 10.88 \\
\hline 75 percent & . & 1.98 & 7.04 & 9.16 & 12.89 & 14.63 \\
\hline \multicolumn{7}{|l|}{ Base Scenario } \\
\hline 50 percent & . & . & . & 1.09 & 3.93 & 5.21 \\
\hline 60) percent & . & . & 1.55 & 3.32 & 6.28 & 7.62 \\
\hline 75 percent & . & - & 4.30 & 6.15 & 9.33 & 10.80 \\
\hline \multicolumn{7}{|l|}{ Base(1.25) Scenario } \\
\hline 50 percent & . & . & . & . & 2.07 & 3.23 \\
\hline 6) percent & . & . & . & 1.51 & 4.20 & 5.41 \\
\hline 75 percent & . & . & 2.41 & 4.08 & 6.94 & 8.24 \\
\hline \multicolumn{7}{|l|}{ Base (1.50) Scenario } \\
\hline 5) percent & . & . & - & . & 0.67 & 1.75 \\
\hline 60 percent & 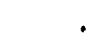 & . & . & 0.14 & 2.65 & 3.76 \\
\hline 75 percent & 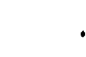 & . & 0.98 & 2.54 & 5.17 & 6.36 \\
\hline \multicolumn{7}{|l|}{ Base(2.00) Scenario } \\
\hline 50) percent & . & . & • & & . & . \\
\hline 60 percent & . & 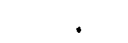 & . & 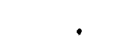 & 0.41 & 1.41 \\
\hline 75 percent & 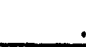 & & 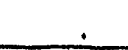 & 0.31 & 2.66 & 3.71 \\
\hline
\end{tabular}

a $\wedge$ "." signifies that the return is less than zero. 
APPENDICES 


\section{APPENDIX A: WILDLIFE AND WILDLIFE RESOURCES}

\section{A.1 Wildlife and Wildlife Resources}

The wetter, higher areas east of the Rift Valley offer the best opportunities for agriculture and have, therefore, been settled and/or cultivated at widely fluctuating levels of intensity for millennia (the Amman area has been continually occupied since 8000 to 7000 B.C.). Thus, not surprisingly, the landscape and attendant wildlife communities in these areas have been extensively modified. In the more arid areas, the major impacts of human habitation come from overgrazing of livestock and removal of woody vegetation for fuel. In some areas, water is trucked in for the herds of sheep and goats. This has permitted overgrazing in remote, arid areas during the summer months when the rangeland can least endure the additional stress.

Jordan has no pational parks, only several wildlife reserves formally designated but with only informal pmtection (Arzaq Wetland and Shaumari Wildlife Reserves). Draft legislation has bcen prepared for the establishment of national parks, but has never been adopted by the government. A proposed Wildlife Conservation Act (first drafted in 1979, but also never enacted) would allow for roughly comparable control to be exercised over wildlife reserves as that which would be expected for national parks.

Wildlife resources near the Sultani site are similar to those of extensive stretches of land along the Desert Highway. There auc no existing protected areas in conflict with the site, but one has been proposed immediately to the west. 1 There are only 12 proposed or de facto existing wildlife reserves in Jordan. These have been chosen to cover as wide as possible a cross section of the country's various ccosystems and indigenous biotic communities. Efforts were taken in the selection process to minimize conflict with existing land uses and to factor in ease of administration and budgetary considerations. Figure A.1 displays the locations of these, with the proposed Abu Rukbah Wildlife Reserve identified immediatcly west of the Sultani site.

The purpose of the $410-\mathrm{km}^{2}$ Abu Rukbah Wildlife Reserve would be to protect and preserve representative areas of the Western Highlands (Karak Plateau) and the Makraq Steppe land types together with their indigenous flora and fauna. A long-term goal is the protection of range until such time that the reserve lands could be capable of sustaining the reintroduction of large animals (e.g., gazelles). The entire reserve would be fenced because of the pressures for grazing and, on the western edges, cultivation. The Royal Socicly for the Conservation of Nature, in conjunction with the International Union for the Conservation of Nature and the World Wildlife Fund, has ranked the priority for establishment of protection of Jordan's 11 proposed wildlife reserves.' The Abu Rukbah reserve is one of three in the fourth, or lowest, priority category.

No extensive floral and faunal surveys have been conducted in the Sultani area or in the proposed reserve. Dati on animal occurrence and distribution, according to Clarke, are particularly deficient. Plant cover in the proposed Abu Rukbah Wildlife Reserve has been greally reduced to almost pure stands of Anabasis syriaca duc to overgrazing, but in the wadis, Clarke 'reports that Atriplex halimus appears along with Achillea fragrantissima, Peganum harmala, and Artemisia inculata. He also reports an abundance of the sedgegrass Carex pachystylis, but it also has been highly overgrazed. Plant cover in the Sultani site is comparable, where overgrazing has caused severe damage, biological diversity is resuricted primarily to the wadis, and the hillsides are almost desertic in appearance. Clarke suggests that indigenous mammalian life is restricted to hares and

\footnotetext{
1 Clarke, John F., A Proposal for Wildlife Reserves in Jordan: Development of Wildlife Conservation in Jordan, Royal Society for the Conservation of Nature and the Intemational Union for the Conservation of Nature and the World Wildlife Fund (IUCN/WWF), Amman, Jordan, 9 July 1979. Also, personal communication with Mr. Maher Z. Abu Jafar, General Director, The Royal Society for the Conservation of Nature, Amman, Jordan, 18 April 1988.
} 
ALPENDIX A:

WILDLIFE AND WILLIIFE RESOURCES

probably rodents. Lizards and snakes are common. Resident birds likely include Temminck's horned larks, crested larks, desert larks, and red-rumped wheatears.

One of the two access points to the proposed Abu Rukbah Wildlife Reserve would be from the Desert Highway by Wadi Sultani Station). A ranger post for the eastern portion of the reserve as well as a guard post for this eastern entry is proposed at Sultani Station. 
APPENDIX A:

WILDLIFE AND WILDLIFE RESOURCES

page A-3

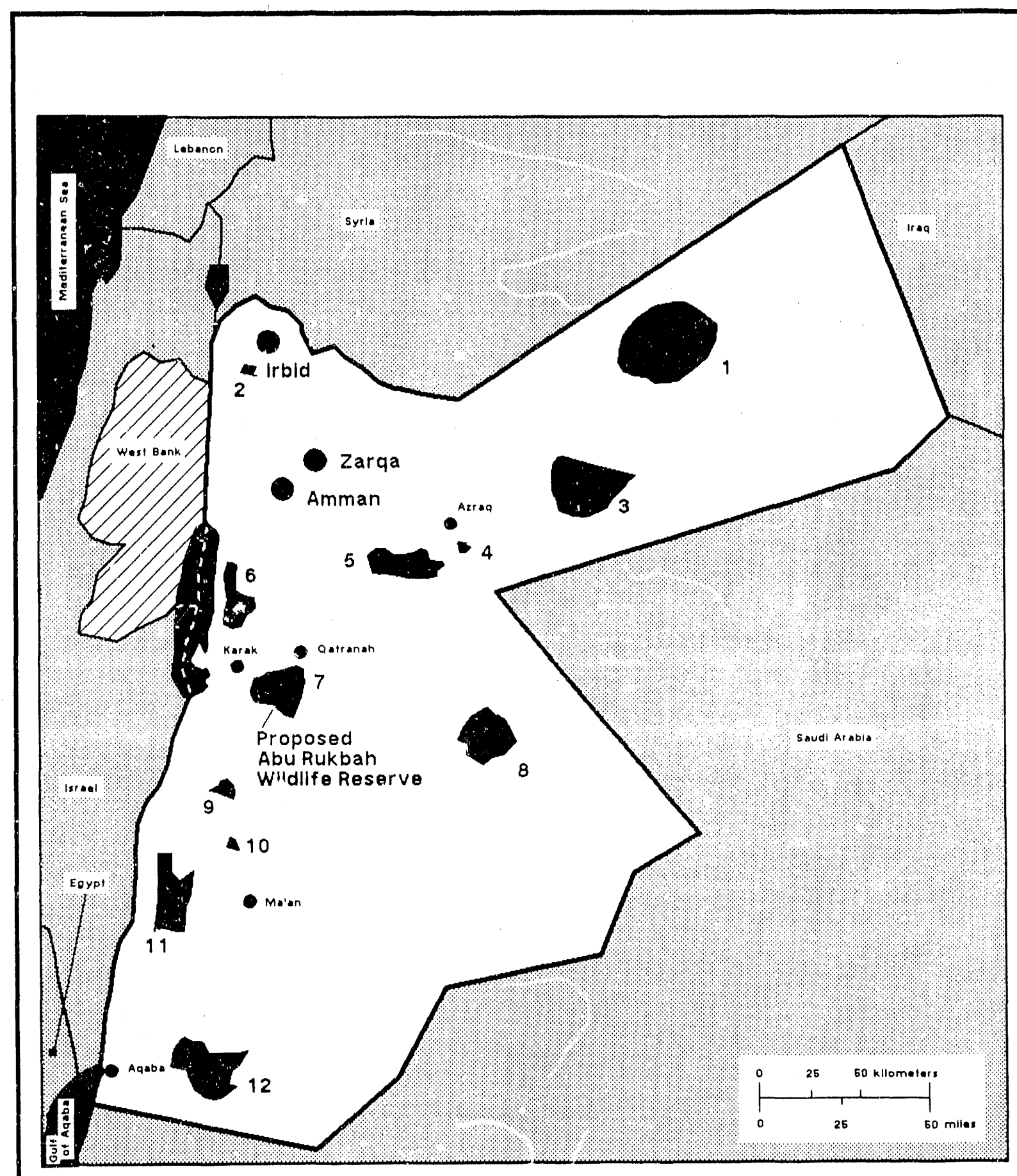

Figure A.1

Location of Jordan's 12 proposed wildlife reserves, showing the Abut Rukbah Wildlife Reserve (highlighted), just west of the Sultan site. 


\section{APPENDIX B: FEASIBILITY OF DRAGLINES}

\section{B.1 IN'TRODUCTION}

The Bechtel Group mentions that they considered use of a dragline to reduce overburden removal costs. The April site visit by the study team included visitation to the El Abiad Mine to observe, among other objectives, a dragline in opcration there and discuss its applicability to the proposed Sultani mining operation. The Bechtel Group concluded in there study that a dragline operation was not appropriate for the Sultani operation - without elaboration or reasons given. ORNL investigated further the potential for dragline(s) opcration at Sultani as an alternative to using trucks and shovels for overburden removal. An official of the JPMC has estimated that overburden removal costs could be halved through use of a dragline. Bucyrus-Erie representatives, the vendors supplying the JPMC draglines, also stressed a closer look at the option, based on what they knew of the Sultani plans and their knowledge of the experiences with draglines at the El Hasa and El Abiad mines. The following constitutes this closer examination of the feasibility of using draglines.

\section{B.2 FINDINGS ON THE FEASIBILITY OF IRAGIINES}

There are two major factors which dominate any consideration of dragline feasibility at the Sultani mining operation: (1) the immediatc and greal capital investment required if a single large walking dragline were to bo used and (2) the great depth of the box cut that would necessitate removing a large pereentage of the material by use of trucks and front-end loaders to the out-ol-pit storige area, resulting in additional costs.

If we assume a 5()-MW plant as the initial unit, later phased with another 50-MW unit and then three sucessive additions of $100 \mathrm{MW}$ cach until a total of $400 \mathrm{MW}$ of capacily is reached, several scenarios for dragline use can be assessed. The original 5()-MW plant would be supplied with fuel made accessible by removing overburden with a loader and truck operation, as suggested by the Bechtel Group. Assuming a 90()-shifts-per-year work schedule (as per Bechtel), the economic life of the major units (loaders, dozers, trucks, and scrapers) would require replacement of the entire flect in approximately $41 / 21051 / 2$ ycars after start-up. During this period, the initial development and box cut would have been compleled and an ongoing pit well established. According to the Bechtel Group, approximately $\$ 39$ million of new capital investment would be needed at that time to replace the older equipment and to purchase new shovels and trucks reguired for the increased rates of production as the 10()-MW units come on stream. Thus, an opportunity would exist at that time to consider phasing in draglines as an alternative to continuing to meet an increased production schedule with truck and shovel technology. The capital investment for the shovel-truck operation would not be exceeded and the objection to opening of the box cut with draglines would be surmounted.

\section{B.2.1 Multiple Small Draglines}

The chief remaining question would be the applicalility of draglines to the existing restraints of depth and type of overburden, production requirements, dimensions of the pit required for the mining equipment, otc. One way of addressing these questions is the use of two or more smaller draglines. The high capital investment of a single large dragline of sufficient capacity to handle removal of all the overburden would be avoided, smaller draglines would allow a better phasing of the requircd calpital investment as production requirements increased, and production capability could be adjusted as the stripjing ratio varied over the life of the mine.

\footnotetext{
1 The analysis described here was conducled by i.). Samuel Shaw, III, I.IF., Golden, Colorado and is based on his repon to ORNL, December 1988.
} 
APPENDIX B:

Acquisition of a 31 - to $34-\mathrm{m}^{3}$ capacity dragline 10 work in tandem with a smaller crawler-mounted dragline of about $18-\mathrm{m}^{3}$ bucket capacity would have a total capital investment (including all costs of transportation, erection, electrics, and buckets) of approximately $\$ 16.2$ million for the larger machine and $\$ 6.5$ million for the smaller - a total of $\$ 22.5$ million.

Prior to the period when the deepest overburden is encountered - about 10 to 12 years into mine operation - a second small dragline could be purchased. This machine could be dedicated to pulling back spoils from the other two machines so that maximum pit depth of about $60 \mathrm{~m}$ could be accommodated. 2

Another possible combination would be to purchase a 50 - $\mathrm{m}^{3}$ walking dragline and team it with the $18-\mathrm{m}^{3}$ crawler dragline. The capital investment would be approximately $\$ 25.25$ million for the larger machine and $\$ 6.5$ million for the smaller one. With this combination, the second small unit would not be required in those areas having the higher stripping ratios.

\section{B.2.2 Effect of Multiple Small Uraglines on Annual Operating Costs}

Annual operating costs were computed for cach multiple dragline combination and an estimation was made of the change in operating costs of the stripping cyuipment and various support units that would be replaced by the dragline operation. Similarly an estimate was made of the changed manpower requirements (approximately 88 hourly personnel) and the resultant change in labor costs. Relevant dati came from the appropriate tables in the Bechtel Group report.

The respective yearly operating costs of the dragline operations versus those of the shovel and truck operation are displayed in Table B.1.

\section{B.2.3 Effect of Multiple Small Draglines on Operational Logistics and Safety}

Although the use of draglines would result in lowered costs of stripping, ocher aspects do not appear as favorable. Because of the Sultani site's significant overburden thickness and the great depth of the lower layers of the oil shale deposit, the stability of any spoils piles produced by the draglines must be assured. Depending on the amount and the location of groundwalter inflows likely to be encountered in some of the decper mining, there could be a marked effect on the stability of the spoils. Consideration must be given to the possible effects on the stability of the high spoils banks if the lower portions are salturated, especially at the toes of such spoils pilcs.

Another significant constraint to dragline use is the 8()$-\mathrm{m}$ width of the pit as contemplated in the Bechtel Group's design for the truck and shovel of ration. The maximum practical width possible with use of draglines would be more nearly only $30 \mathrm{~m}$. This would greally reduce the area for mancuvering equipment in the pit bottom, especially that required for the CAT-785 trucks. It is also probable that this width would be insufficient for the effective use of the two continuous miners planned by the Bechtel Group's mining scheme. Probably of equal concern, the reduction in width increases the potential danger from even small slides from

\footnotetext{
2 There is a relatively small area where the depth of the overhurden is $6.5 \mathrm{~m}$. It is possible, in consideration of the limited extent of this area, that the prestripping of $51010 \mathrm{~m}$ might be contracted to locial mining companies with machinery scaled to the task.
} 
Table B.1 Annual operating costs compared: multiple draglines vs. truck and shovel technology

\begin{tabular}{|c|c|c|c|}
\hline Costs & $\begin{array}{l}\text { Truck } \\
\text { and } \\
\text { Shovel } \\
\text { (s million) }\end{array}$ & $\begin{array}{c}\text { One } \\
\text { 31- to 34- } \mathrm{m}^{3} \text { Dragline, } \\
\text { Two } \\
18-\mathrm{m}^{3} \text { Draglines } \\
(\mathrm{s} \text { million })\end{array}$ & $\begin{array}{c}\text { One } \\
50-\mathrm{m}^{3} \text { Dragline, } \\
\text { One } \\
18-\mathrm{m}^{3} \text { Dragline } \\
(\$ \text { million }) \\
\end{array}$ \\
\hline \multicolumn{4}{|l|}{ Direct Costs } \\
\hline $\begin{array}{l}\text { Various trucks, shovels, ctc. } \\
\text { P\&H } 2355 \text { Dragline } \\
\text { P\&H } 752 \text { Dragline } \\
\text { P\&H } 757 \text { Dragline }\end{array}$ & 5.791 & $\begin{array}{l}2.08() \\
2.314\end{array}$ & $\begin{array}{l}1 .(140) \\
3.599\end{array}$ \\
\hline Additional Labor & 0.510 & & \\
\hline Totals & 6.3() 1 & 4.394 & 4.639 \\
\hline $\begin{array}{l}\text { Diffcrence } \\
\text { (percent) }\end{array}$ & & $\begin{array}{l}-1.9(07 \\
-3(0.3\end{array}$ & $\begin{array}{l}-1.662 \\
-26.4\end{array}$ \\
\hline Depreciation & $3.4(15$ & 1.46() & 1.822 \\
\hline $\begin{array}{l}\text { Difference } \\
\quad \text { (percent) }\end{array}$ & & $\begin{array}{l}-1.583 \\
-46.5 \\
\end{array}$ & $\begin{array}{l}-1.945 \\
-57.1 \\
\end{array}$ \\
\hline
\end{tabular}

either the highwall or the spoil bank. Not long into llie development of the mining operation, the pits will increase to significant lengths. This will reguire the spoil banks to remain stable for comparatively long periods of time so as not to jeopardize the integrity of the main haul road located in the pit bottom.

\section{B.3 CONCLUSIONS}

It would be possible to strip the overburden using multiple draglines with 28 - to 34 -percent rehandle.

Use of draglines would reduce unit costs of stripping overburden

Because of the unusual height of spoil banks and highwalls, presence of groundwater affecting the stability of the spoil banks, plus severe limits on the width of the pit attainable, the safety requirements for equipmient and personnel appear to make the use of draglines impractical.

- In addition to the reasons of safety, the greal length of the pits will require spoil banks to be stable for comparatively long periods of time to preserve haul roads in the bottom of the pit, and this may not be possible under the conditions noted. 
- Consideration should be given to a possible combination of a dragline and a truck and shovel operation. If a truck and shovel operation were used for prestripping, it may be possible to solve the problems of high spoil banks, spoil instibility, and narrow pit width and still use the more cost-effective dragline for handling a large proportion of the overburden.

Study of a dragline alternative indicates that although more cusi-effective than the shovel-truck concept, their use in moving 100 percent of the overburden is impractical becaluse of salety and operating constraints. It is recommended that additional study be given to the possible design of a mining system incorporating both concepts, utilizing the inherent cost-effectiveness of draglines to the greatest extent possible. 


\section{APPENDIX C: HEALTH EFFEC'TS OF FLY ASH AND O'THER DUST}

\section{C.1 IN"r. RODUCTION}

The five main factors which influence the interaction between dust and the human body are:

(1) physical characteristics (size, shape, hardness);

(2) chemical composition;

(3) concentration in the atmosphere;

(4) duration of exposure; and

(5) individual susceptibility.

The size of the dust particles that may be encountered due to the processes of the plant are described in Section 7.3. Shape and hardness are unknown at the current level of this prefeasibility study. The chemical composition is described in Section 7.3.2. Individual susceptibilities among the work force are unknown. The duration of exposure is, in part, a normal 4()-h work weck, but also dependent on local meteorological and topographic conditions.

Dust deposited in the lungs may cause pneumoconiosis, which can be disabling or not, depending on whether or not the dust is physiologically active and on individual susceptibility. Generally, the disabling forms of pneumoconiosis are caused by crystalline silica or yuarty $\left(\mathrm{SiO}_{2}\right)$. Based on the test burn results, there is very little silicon in the Sultani ash.

According to the U.S. Bureatu of Mines, dust of these particle sires have these retention rates in human lungs:

Table C.1 Dust retention in human lungs

\begin{tabular}{cc}
\hline $\begin{array}{c}\text { Particle Diameter } \\
\text { (micrometers, } \mu)\end{array}$ & $\begin{array}{c}\text { Approximate Retention } \\
\text { in Human Lungs (\%) }\end{array}$ \\
\hline $6-10$ & 2() \\
5 & 25 \\
4 & 42 \\
3 & 50 \\
2 & 70 \\
1 & 70 \\
0.5 & 50 \\
\hline Source: U.S. Burcau of Mines, Sampling and Evalualing Respirable Coal Mine Dust:
\end{tabular}

For consideration of health effects, total dust is much less important than respirable dust. In this regard, for the Sultani fly ash samples tested, about 1) pereent of the ash were below $4 \mu$ in diameter and a total of 26.5 perent were below $10 \mu$. One half of the fly ash sampled were below $24.9(1)$. Thus, from the perspective of particle size alone, the fly ash represents a potential health hazard.

Dosage received by humans is the product of dust concentration and exposure time. To further define both of these values for the Sultani site, it is necessary to know more of those conditions that might cause dust particles to become airborne and how long might one expect those conditions to exist on an annual basis. This procedure 
can be generalized in a six-step process that includes more than just site melcorology and particle size distributions. ${ }^{1}$

(1) Determine Particle Size Distribution. From Section 7.3, it is known that the fly ash ranges in size from $2 \mu$ to $176 \mu$ in diameter.

(2) Estimate Threshold Friction Velocity. A threshold friction velocity $\left(U_{D}\right.$, the wind speed at sound level necessary to initiate thr airborne suspension of particulates needs to be delermined. Its value depends on particle size distribution, the presence or absence of surliace crusting, soil or substrate water concentration, and the presence or absence of nonerodible elements such as vegetation or stones.

(3) Determine the Roughness Height of the site terrain. The roughness height $\left(Z_{0}\right)$ is a measure of the size and spacing of surface irregularitics, such as trecs or buiklings, that obstruct wind flow. This parameter is used to convert the threshold friction velocity at ground level to wind speed at a typical weather station height of $7 \mathrm{~m}$.

(4) Determine the Threshold Wind Velocity. The threshold wind velocity $\left(U_{t}\right)$ is the wind specd, as measured at a wind sensor station gencrally $7 \mathrm{~m}$ above the ground, that is necessary to initiate soil crosion (in this case, lifting of the dust). The threshold wind velocity is detemined from the threshold friction velocity, $U_{t}$ according to this equation: ${ }^{2}$

$$
U_{1}=U_{f}\left(13.1-2.5 \ln Z_{0}\right)
$$

where

$$
\begin{aligned}
& U_{f}=\text { Threshold Wind Velocily at } 7 \mathrm{~m}(\mathrm{~m} / \mathrm{s}), \\
& U_{f}=\text { Threshold Friction Velocily }(\mathrm{m} / \mathrm{s}), \text { and } \\
& Z_{o}=\text { Roughness Height }(\mathrm{cm}) .
\end{aligned}
$$

(5) Estimate the Respirable Particulate Emission Rate

Cowherd et al. developed this equation to estimate the annual average emission rate of respirable particulate matter from crodible surfaces:

$$
E_{10}=\left(1 .\left(136\left(1-1^{\prime}\right)(U / 4)\right)_{1}^{3}|F(X)|\right.
$$

where

$$
\begin{aligned}
& E_{10}=\text { Emission rate for total respirable particulate matter }\left(\mathrm{PM} 1(\mathrm{l}){ }^{(\mathrm{g} / \mathrm{m} 2-\mathrm{h})}\right. \text {, } \\
& U=\text { Mean annual wind spect }(\mathrm{m} / \mathrm{s}) \text {, and }
\end{aligned}
$$

\footnotetext{
1 Leu, David J. and Paul W. Hadley, "The California Site. Mitigatien Decision Pree l'rocess: Sulving the "How Clean Should Clean

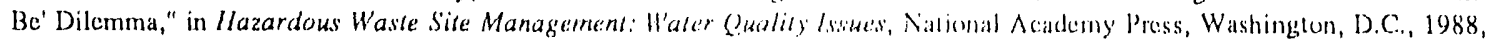
pp.67-97.
} 
APPENDIX C:

HEALTH EFFECTS OF FLY ASII AND OTIER DUST

$$
[F(X)\rfloor=0.18\left(8 x^{3}+12 x\right) / e^{x 2}, \text { where } x=0.886(U / U)
$$

(6) Project downwind particulate concentrations. From the above ecjuations, one can derive a conservative annual estimate of the total dust concentration at the site boundary in $\mu \mathrm{g} / \mathrm{m}^{3}$. This assumes a uniform distribution of dust particles on the ground across the site.

A dispersion model is still required to translate emissions estimates to projected ambient levels. Again, this is planned to be a priority task in a full enginecring leasibility analysis. 

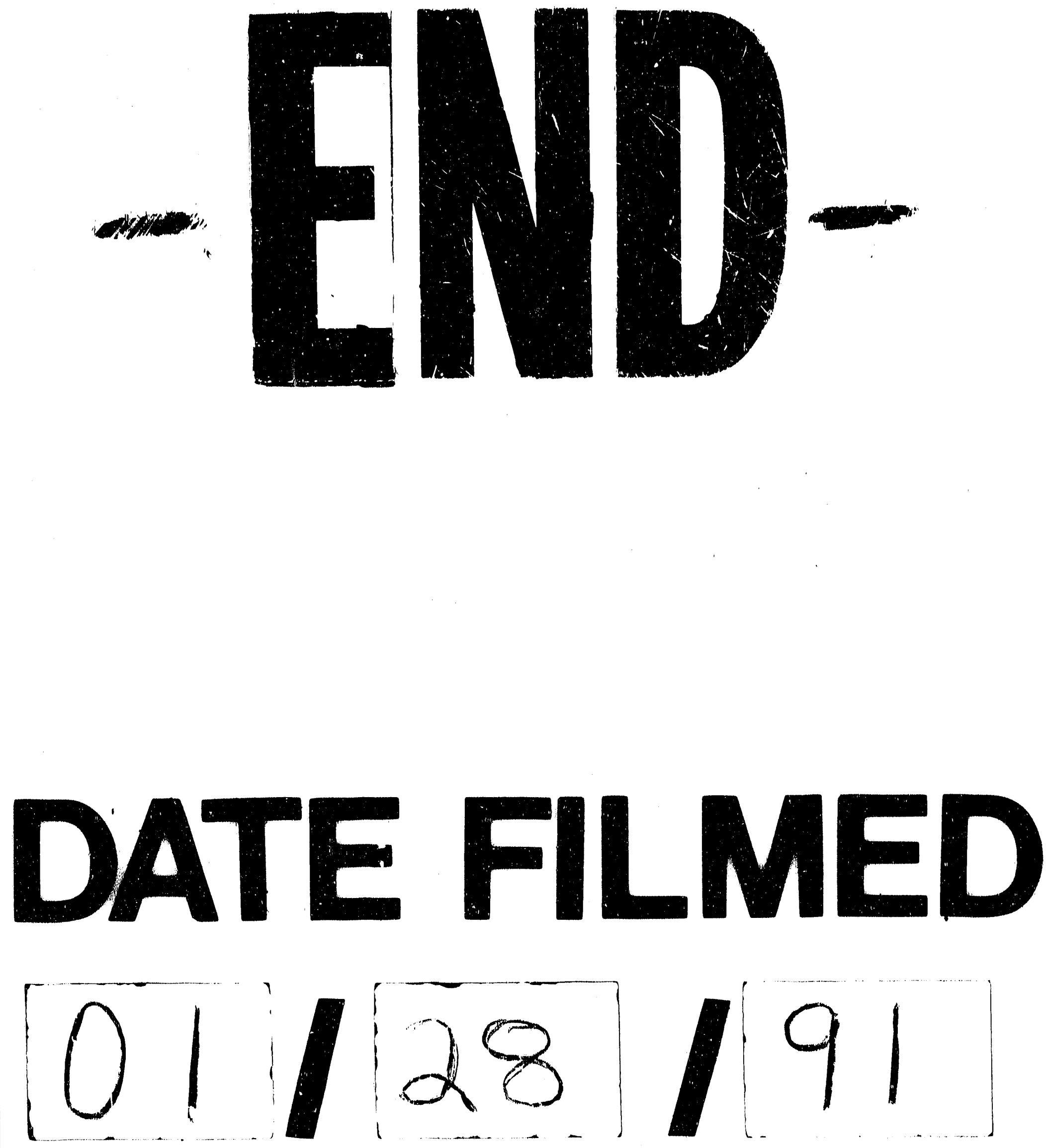
